
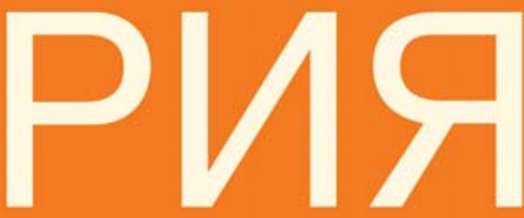

$2(98) / 2019$

Подписной индекс 09850

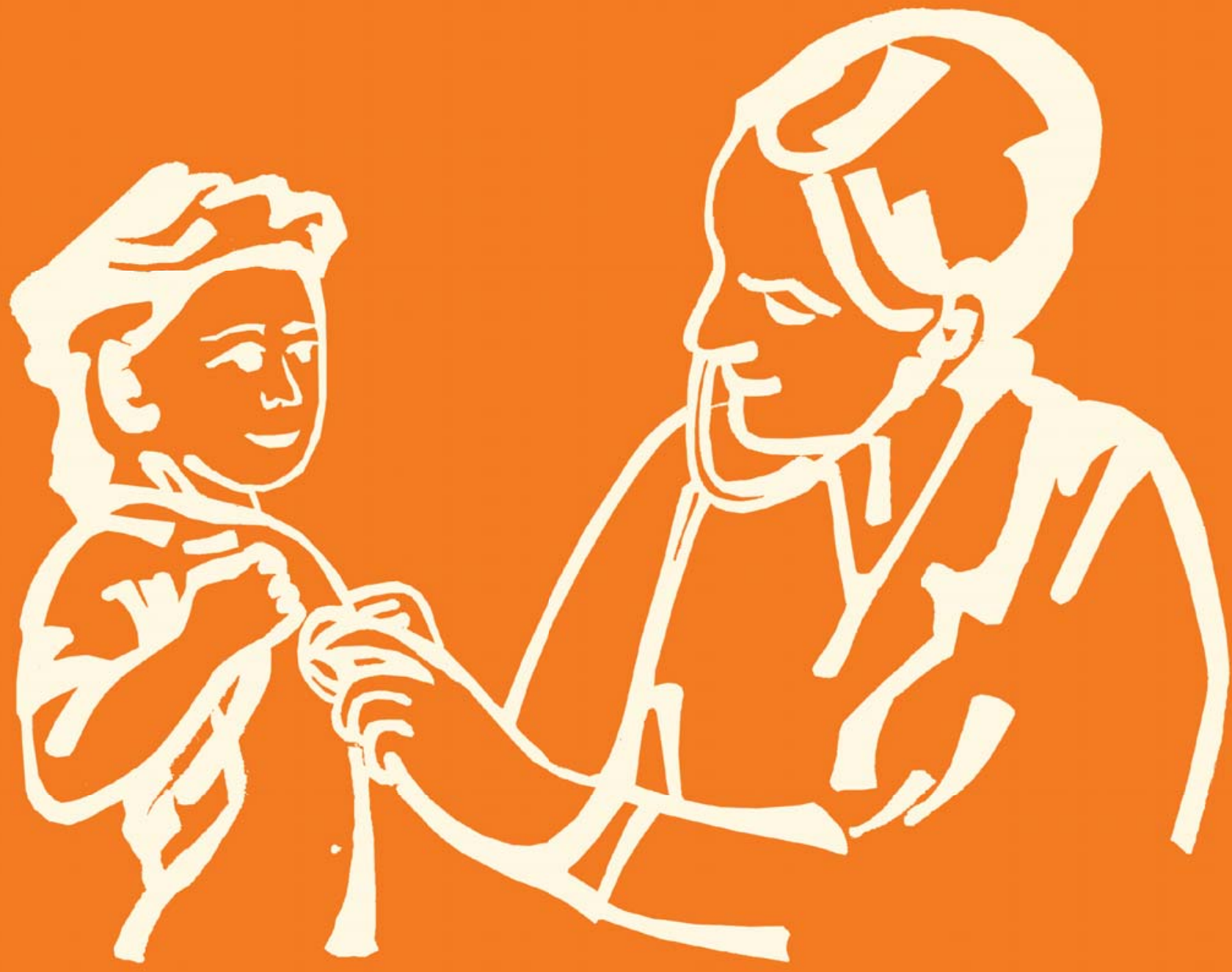




\section{川
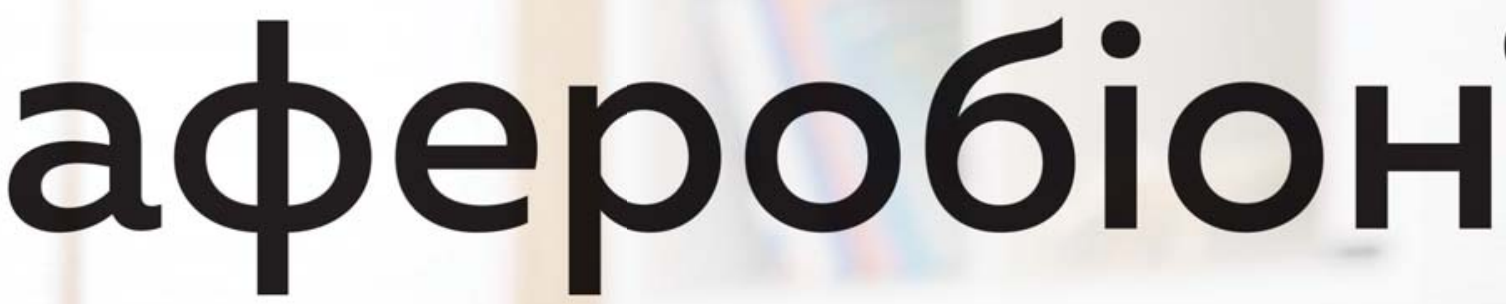 \\ R}

\section{НЕХАЙ ДІТИ РОСТУТЬ БЕЗ ГРИПУ ТА ЗАСТУД!}
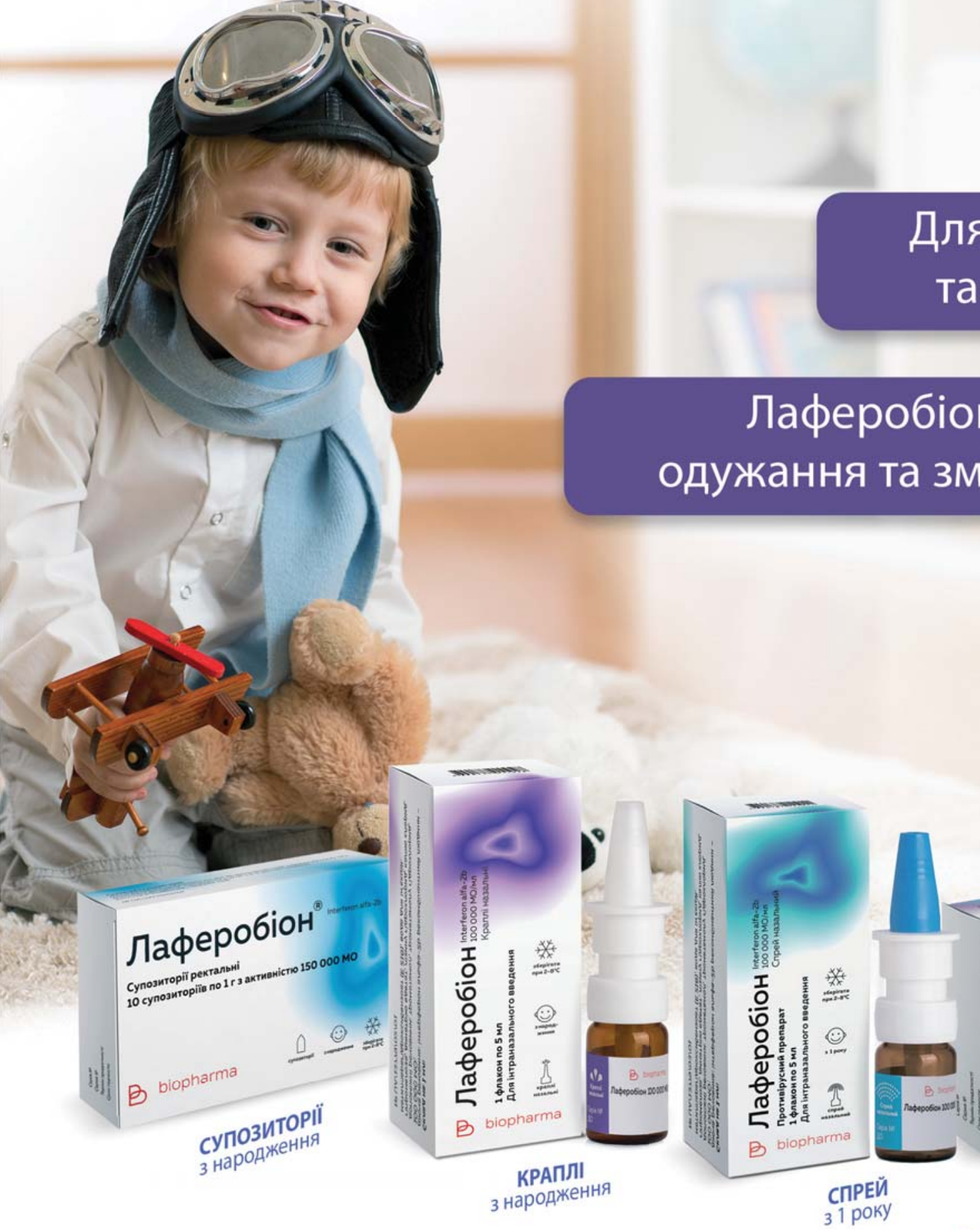

\section{Лаферобіон}

\section{Для профілактики \\ та лікування ГРВІ}

\section{Лаферобіон - прискорить одужання та зміцнить імунітет}

\footnotetext{
* Вислів «Нехай діти ростуть без грипу та застуд!» використовується як побажання здоров'я.
}

Згідно з інструкцією для медичного застосування лікарського засобу Лаферобіон® (каплі назальні, спрей назальний, супозіторії 150 000 та 500 000МО). Інформація призначена виключно для професійної діяльності медичних та фармацевтичних працівників, для розповсюдження на спеціалізованих семінарах, конференціях, симпозіумах з медичної тематики або для розміщення в спеціалізованих медичних виданнях. Перед призначенням слід обов'язково ознайомитися з інструкцією для медичного застосування. Інформація надана скорочено. Р.П. №UA/13779/02/01, №UA/13779/03/01 згідно Наказу МO3 України №661 від 09.10.2015 р. Р.П. №UA/13779/01/02, №UA/13779/01/01 згідно Наказу МОЗ України №513 від 21.07.2014 р. Виробник: ТОВ “Ф3 "БІОФАРМА”,

Україна, м. Біла Церква, вул. Київська, 37. Тел.: +38 (044) 277-36-10. Вартість дзвінків згідно з тарифами вашого оператора зв'язку 


\section{ПЕРЕМОЖНА СИЛА 100\% морської води}

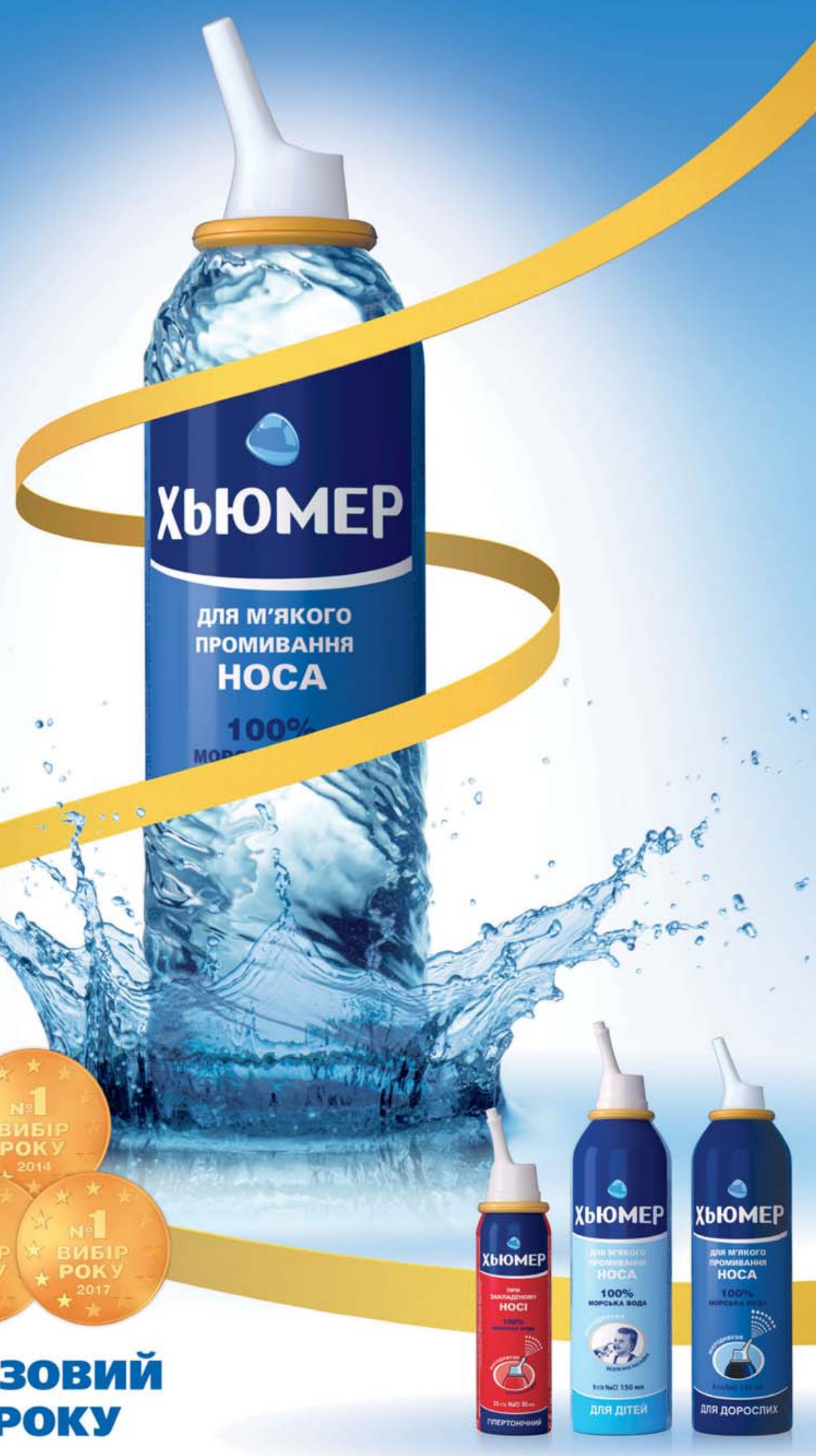


SHUPYK NATIONAL MEDICAL ACADEMY OF POSTGRADUATE EDUCATION

UKRAINIAN INSTITUTE OF STRATEGIC STUDIES OF THE MINISTRY OF HEALTH OF UKRAINE BAKHTIYAROVA D.O.

\section{SOVREMENNAYA PEDIATRIYA Scientific and Practical Journal}

Chief Editor

Berezhniy V.V., Doctor of Medical Science, Professor of Pediatrics, Shupyk National Medical Academy of Postgraduate Education, Kyiv, Ukraine Editor-in-Chief

Chernyshova L.I., Doctor of Medical Science, Professor of Pediatrics, Shupyk National Medical Academy of Postgraduate Education, Kyiv, Ukraine

Valiulis A., Professor, CEO of Clinic of Asthma, Allergy and Chronic Lung Diseases, CEO of EduCom (postgraduate education), Executive Committee member $\mathcal{E}$ Treasurer of European Academy of Paediatrics (EAP/UEMS-SP), Vilnius, Lithuania

Chief Scientific Adviser

Antipkin Yu.G., Academician of the National Academy of Medical Science of Ukraine, Director of the SI «Institute of Pediatrics, Obstetrics and Gynecology named of academician O.M. Lukyanova of the NAMS of Ukraine», Kyiv

Deputy Editor-in-Chief

Mamenko M.E., Doctor of Medical Science, Professor of Pediatrics, Shupyk National Medical Academy of Postgraduate Education, Kyiv, Ukraine;

Scientific Editor

Marushko R.V., Doctor of Medical Sciences, SI «Institute of Pediatrics, Obstetrics and Gynecology named of academician O.M. Lukyanova of the NAMS of Ukraine», Kyiv

Project Director D.O. Bakhtiyarova

Executive Editor I.O. Sheiko

Layout and design V.S. Scherbatykh

\section{EDITORIAL BOARD}

Abaturov A.E. (Dnipro, Ukraine) Aryayev M.L. (Odesa, Ukraine) Banadyga N.V. (Ternopil, Ukraine) Beketova G.V. (Kyiv, Ukraine) Bogmat L.F. (Kharkiv, Ukraine) Vaildeliene L. (Kauno, Lithuania) Veres Gabor (Budapest, Hungarian ) Volokha A.P. (Kyiv, Ukraine) Geppe N.A. (Moscow, Russia) Gorovenko N.G. (Kyiv, Ukraine) Hubertus von Voss (Munich, Germany) Dudnik V.M. (Vinnytsia, Ukraine) Yemets I.M. (Kyiv, Ukraine) Zaychenko A.V. (Kyiv, Ukraine) Zvolinska D. (Wroclaw, Poland) Ivanov D.D. (Kyiv, Ukraine) Yspaeva Zh.B. (Almaty, Kazakhstan) Kvashnina L.V. (Kyiv, Ukraine) Kozlov R.S. (Smolensk, Russia)

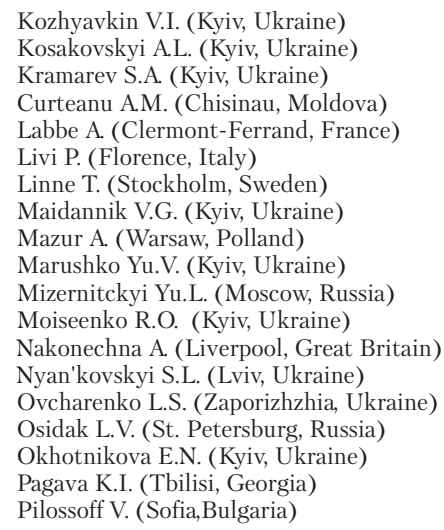

Prodanchuk M.G. (Kyiv, Ukraine) Puzievicz-Zmonarska A (Wroclaw, Poland) Rosenthal M. (London, Great Britain) Simanis R. (Riga, Latvia) Slabkoi G.A. (Uzhhorod, Ukraine) Smiyan A.I. (Sumy, Ukraine) Umanets T.R. (Kyiv, Ukraine) Urbonas V. (Vilnius, Lithuania) Usonis V. (Vilnius, Lithuania) Hadjipanayis A. (Nicosia, Cyprus) Husain S. (London, Great Britain) Chernyshov V.P. (Kyiv, Ukraine) Shadrin O.G. (Kyiv, Ukraine) Soder O. (Stockholm, Sweden) Shyshko G.O. (Minsk, Belarus) Shun'ko E.E. (Kyiv, Ukraine) Yankovskyi D.S. (Kyiv, Ukraine)

\section{PUBLISHERS GROUP OF COMPANIES MED EXPERT, LLC}

Certificate of state registration КВ 15780-4252 ПР from 27.10.2009 y., the Published since December 2003 y.

$$
\begin{gathered}
\text { Published with the scientific support of the SI «Institute of Pediatrics, Obstetrics and Gynecology named of academician O.M. Lukyanova } \\
\text { of the National Academy of Medical Science of Ukraine» } \\
\text { Publishing frequency - } 8 \text { Times/Year }
\end{gathered}
$$

Qualified by the Higher Attestation Commission of Ukraine, the Decree of the Presidium of the Higher Attestation Commission of Ukraine No. 1222 from 07.10.2016 Recommended by the Shupyk National Medical Academy of Postgraduate Education, Protocol No.3 from 13.03.2019

Recommended by the Academic Council of the Ukrainian Institute of Strategic Studies, the Ministry of Health of Ukraine, Protocol No.2 from 26.02 .2019 Passed for printing 25.03.2019

Mailing address:

GROUP OF COMPANIES MED EXPERT,

«SOVREMENNAYA PEDIATRIYA

p/b 80, Kiev, Ukraine, 04211

Tel./fax: +38 044 498-08-80

E-mail: pediatr@med-expert.com.ua

http://med-expert.com.ua
Format 60x90/8. Offset paper.

Conventional printed sheet. 13,95

Total circulation is 8,000 copies.

Ord. No.26.03/01 from 26.03.2019

Printed from the final films

in the «Aurora-print» printing house,

Prichalnaya Str. 5, Kiev, tel. (044) 550-52-44

Certificate A00No.777897 from 06.07.2009
All articles are reviewed. Total or partial reproduction by any means of the materials published in this edition is allowed only by written permission of the publisher. Advertiser takes responsibility for the content of advertisements.

(c) Shupyk National Medical Academy of Postgraduate Education, 2019 c) Ukrainian Institute of Strategic Studies, Ministry of Health of Ukraine, 2019 (C) Bakhtiyarova D.O., 2019

Journal "SOVREMENNAYA PEDIATRIYA" is reviewed by the Institute of Information Recording Problems of the National Academy of Science of Ukraine

MEDLINE, Index Copernicus International, Directory of Open Access Journals (DOAJ), WorldCat, РИНЦ, Science index (eLIBRARY.RU) и Google Scholar, CrossRef, Ulrich, Academic Resourse Index, Infobase index, Scientific Indexing Services, BASE, DRJI, Hinari, IIJIF, OAJI. 


\title{
СОВРЕМЕННАЯ ПЕАИАТРИЯ
}

\author{
Научно-практический педиатрический журнал
}

\section{СУЧАСНА ПЕ,ААТРIЯ}

Науково-практичний педіатричний журнал

Шеф-редактор

Бережной В.В., доктор мед. наук, профессор, НМАПО имени П.Л. Шупика, Киев, Украина

Главный редактор

Чернышова Л.И., доктор мед. наук, профессор, НМАПО имени П.Л. Шупика, г. Киев, Украина

Валиулис А., профессор, Генеральный директор клиники астмы, аллергии и хронических заболеваний легких, Генеральный директор

EduCom (последипломное образование), Член Исполнительного комитета и казначей Европейской академии педиатрии (EAP/UEMS-SP),

г. Вильнюс, Литва

Главный научный консультант

Антипкин Ю.Г., академик НАМН Украины, директор ГУ «ИПАГ имени академика Е.М. Лукьяновой НАМН Украины», г. Киев

Заместитель главного редактора

Маменко М.Е., доктор мед. наук, профессор НМАПО имени П.Л. Шупика, г. Киев, Украина

Научный редактор

Марушко Р.В., доктор мед. наук, ГУ «ИПАГ имени академика Е.М. Лукьяновой НАМН Украины», г. Киев

Директор проекта Д.О. Бахтиярова

Выпускающий редактор И.А. Шейко

Верстка и дизайн В.С. Щербатых

\section{РЕДАКЦИОННАЯ КОЛЛЕГИЯ}

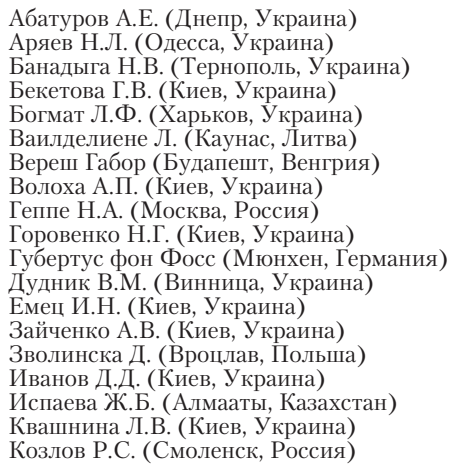

Проданчук Н.Г. (Киев, Украина)

Пузиевич-Змонарска А. (Вроцлав, Польша)

Розенталь М. (Лондон, Великобритания)

Симанис Р. (Рига, Латвия)

Слабкий Г.А. (Ужгород, Украина)

Смиян А.И. (Сумы, Украина)

Уманец Т.Р. (Киев, Украина)

Урбонас В. (Вильнюс, Литва)

Усонис В. (Вильнюс, Литва)

Хаджипанаис А. (Никосия, Кипр)

Хусаин Ш. (Лондон, Великобритания)

Чернышов В.П. (Киев, Украина)

Шадрин О.Г. (Киев, Украина)

Шедер О. (Стокгольм, Швеция)

Шишко Г.А. (Минск, Беларусь)

Шунько Е.Е. (Киев, Украина)

Янковский Д.С. (Киев, Украина)

ИЗДАТЕЛЬ ООО «ГРУППА КОМПАНИЙ МЕД ЭКСПЕРТ

Свидетельство о государственной регистрации СМИ КВ № 15780-4252 ПР от 27.10.2009 г.

Издается при научной поддержке ГУ «Институт педиатрии, акушерства и гинекологии имени академика Е.М. Лукьяновой НАМН Украины» Издается с декабря 2003 г.

Периодичность выхода -8 раз в год

Приказом МОН Украины № 1222 от 07.10.2016 журнал «Современная педиатрия» включен в перечень специализированных научных изданий Украины в области медицинских наук. В издании могут быть опубликованы основные результаты диссертационных работ

Утверждено ученым советом Национальной медицинской академии последипломного образования им. П.Л. Шупика Протокол №3 от 13.03.2019 г. У тверждено ученым советом Украинского института стратегических исследований МЗ Украины Протокол №2 от 26.02.2019 г. Подписано к печати 25.03.2019 г.

Адрес для переписки:

OOО «Группа компаний Мед Эксперт»,

«Современная педиатрия»

а/я 80, г.Киев-211, Украина, 04211 ,

Тел./факс: +38 044 498-08-80

E-mail: pediatr@med-expert.com.ua

http://med-expert.com.ua/

\author{
Формат $60 \times 90 / 8$. Бумага офсетная. \\ У сл. печ. л. 17. Уч.-изд. л. 13, 95., \\ Общий тираж 8000 экз \\ Зак. № 26.03/01 от 26.03.2019 \\ Отпечатано с готовых фотоформ \\ в типографии «Аврора-принт», \\ г. Киев, ул. Причальная, 5, тел. (044) 550-52-44 \\ Свидетельство субъекта издательского дела:
А00 № 777897 от 06.07 .2009 г.
}

Все статьи рецензированы. Полная или частичная перепечатка и тиражирование каким-либо образом материалов,

опубликованных в этом издании, допускается

только по письменному разрешению редакции

Ответственность за содержание рекламных

материалов несет рекламодатель.

(C) Национальная медицинская академия последипломного образования МЗ Украины, 2019

(c) Украинский институт стратегических исследований МЗ Украины, 2019

(C) Бахтиярова Д.О., 2019

Внимание! Подписаться на журнал «Современная педиатрия» Вы можете во всех отделениях связи Украинь Подписной индекс 09850

\section{Журнал «Современная педиатрия» реферируется Институтом проблем регистрации информации НАН Украины}

Журнал «Современная педиатрия» включен в наукометрические, реферативные и поисковые базы данных: MEDLINE, Index Copernicus International, Directory of Open Access Journals (DOAJ), WorldCat,

РИНЦ, Science index (eLIBRARY.RU) и Google Scholar, CrossRef, Ulrich, Academic Resourse Index, Infobase index, Scientific Indexing Services, BASE, DRJI, Hinari, IIJIF, OAJI. Статьям журнала «Современная педиатрия» присваивается DOI 
МИНИСТЕРСТВО ЗДРАВООХРАНЕНИЯ УКРАИНЫ НАЦИОНАЛЬНАЯ МЕДИЦИНСКАЯ АКАДЕМИЯ ПОСЛЕДИПЛОМНОГО ОБРАЗОВАНИЯ ИМЕНИ П.Л. ШУПИКА УКРАИНСКИЙ ИНСТИТУТ СТРАТЕГИЧЕСКИХ ИССЛЕДОВАНИЙ МЗ УКРАИНЫ
THE MINISTRY OF HEALTHCARE OF UKRAINE SHUPYK NATIONAL MEDICAL ACADEMY OF POSTGRADUATE EDUCATION

UKRAINIAN INSTITUTE OF STRATEGIC STUDIES OF THE MINISTRY OF HEALTH OF UKRAINE

\section{СОВРЕМЕННАЯ ПЕАИАТРИЯ}

Научно-практический педиатрический журнаА

\section{СУЧАСНА ПЕАІАТРІЯ}

Науково-практичний педіатрічний зкурнаА

\section{SOVREMENNAYA PEDIATRIYA \\ Scientific and Practical Journal}

$2(98) / 2019$

\section{ОРИГИНАЛЬНЫЕ ИССЛЕДОВАНИЯ}

Колоскова О.К., Тарнавська С.І.,

Шахова О.О., Прунчак Н.I.

Особливості перебігу неускладненої

позалікарняної пневмонії у дітей

з урахуванням лейкоцитарних індексів крові

Шаповал Л.А., Куркевич А.К.

Роль фетальної ехокардіографії

у визначенні прогнозу для плода

з повною атріовентрикулярною комунікацією

Бабінець Л.С.

Ефективність поєднаного використання

сальбутамолу та екстракту плюща

в амбулаторному лікуванні гострих

респіраторних захворювань

з бронхообструкцією

Сеньковская Л.И., Бирюков В.С., Аряев Н.Л. Ауксологические аспекты дефицита роста у детей Одесской области по данным геоэндемического анализа

Починок Т.В., Журавель О.В., Чернов О.В.

Вміст оксиду азоту та його метаболітів у крові та слизовій стравоходу у дітей з частими респіраторними захворюваннями на тлі гастроезофагеальної рефлюксної хвороби

Спринчук Н.А., Самсон О.Я., Большова О.В. Роль тесту на генерацію інсуліноподібного фактору росту-1 у діагностиці та прогнозі лікування дітей зі збереженою соматотропною функцією

Колоскова О.К., Шахова О.О.,

Тарнавська C.І., Маніліч I.O.

Динамічні показники неспецифічної

гіперсприйнятливості бронхів у підлітків, хворих на бронхіальну астму

\section{ОБЗОРЫ}

Маменко М.є

Вроджений гіпотиреоз: скринінг, діагностика та лікування $з$ огляду на сучасні міжнародні рекомендації

\section{ORIGINAL ARTICLES}

$7 \quad$ Koloskova O.K., Tarnavska S.I., Shakhova O.O., Prunchak H.I. Peculiarities of uncomplicated community-acquired pneumonia in children considering blood leukocytic indices

12 Shapoval L.A., Kurkevich A.K.

The Role of Fetal Echocardiography in Determining the Prognosis for the Fetus with Complete Atrioventricular Septal Defect

18 Babinets L.S.

Effectiveness of co-use of salbutamol and extrakt hederis folia in ambulatory treatment of acute respiratory diseases with bronchoobstruction

23 Senkivska L.I., Biryukov V.S., Aryayev M.L. Geo-endemic analysis of auxiliary aspects of growth deficiency in children of Odessa region

31 Pochinok T.V., Zhuravel O.V., Chernov O.V. Content of nitrogen oxide and its metabolites in blood and esophageal mucosa

in children sickly with respiratory diseases against the bachground of gastroesophagial reflux disease

35 Sprinchuk N.A., Samson O.Ya., Bolshova O.V. The role of insulin-like growth factor-1 generation test in diagnosis and prognosis of treatment for children with a preserved somatotropic function

41 Koloskova O.K., Shakhova O.O., Tarnavska S.I., Manilich I.O.

Dynamic parameters of nonspecific hypersusceptibility of the bronchi in teenagers with bronchial asthma

\section{REVIEWS}

46 Mamenko M.E.

Congenital Hypothyroidism: Screening,

Diagnosis and Treatment from the Perspective of Current International Guidelines 
МАМИ АЯКУЮТЬCIAHKYKU PAAIIOT6'

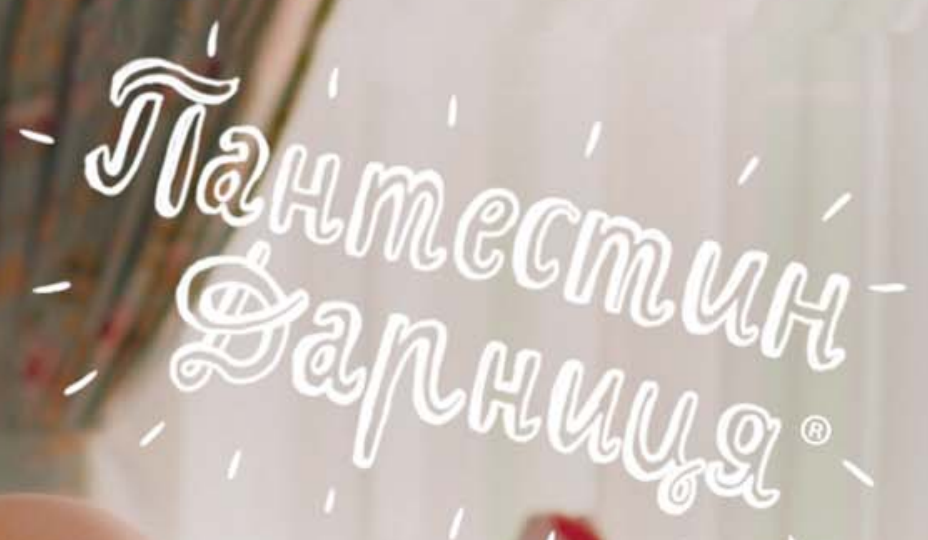

DAPMALEBTИЧHA DIPMA

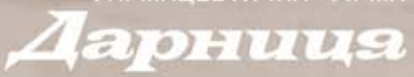
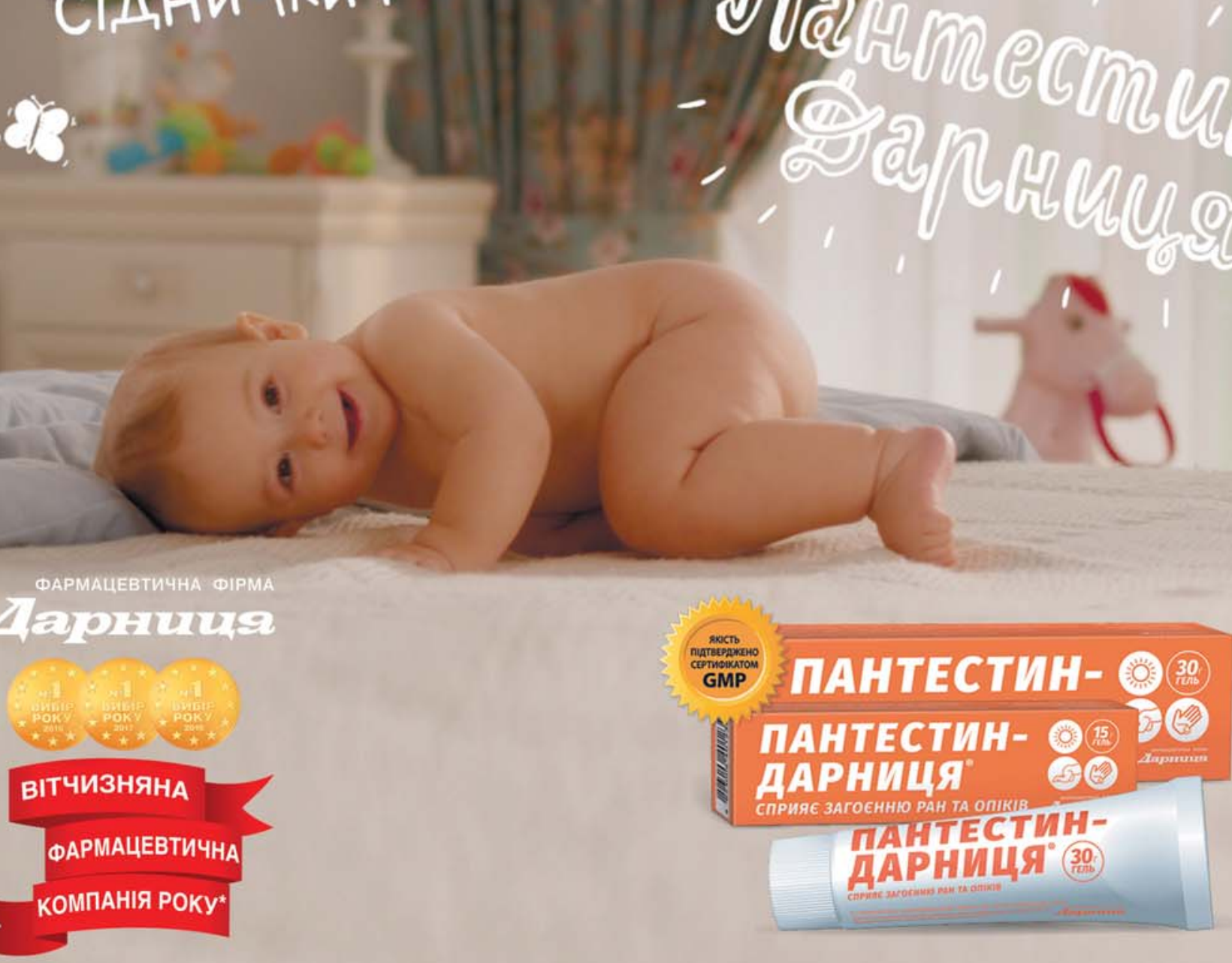

'В даному рекламному сюжеті використовуються рекламні слогани

*За результатами конкурсу споживчих вподобань "Вибір року в Україні" 2016, 2017 і 2018 pp. www.choice-of-the-year.com.ua

Реклама лікарського засобу. Реєстраційне посвідчення МОЗ України № UA/1602/01/01. Відпускається без рецепта. Перед застосуванням лікарського засобу необхідно обов'язково проконсультуватись з лікарем та обов'язково ознайомитись з інструкцією на лікарський засіб. Зберігати у недоступному для дітей місці.
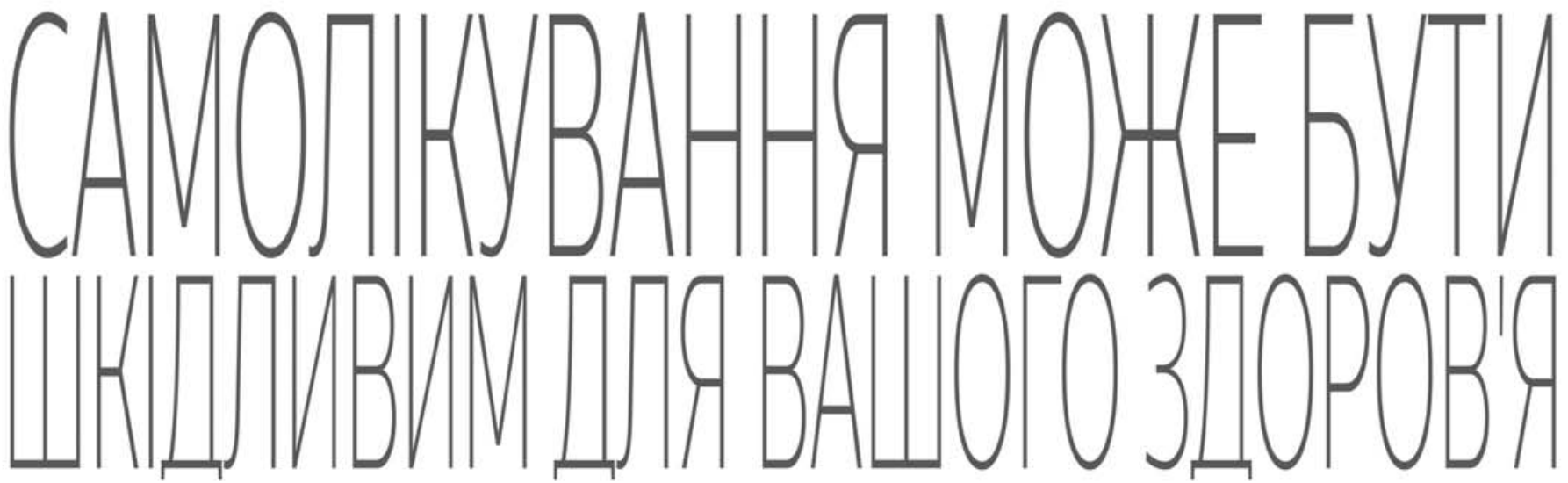


\section{КЛИНИЧЕСКИЙ СЛУЧАЙ}

Черник-Булент А.Ф.,

Гаджиева Ф.Ф., Мамедова Ф.М.

Редкий случай мукополисахаридоза VI типа: болезнь Марото-Лами (ошибки диагностики)

Душар М.І., Акопян Г.Р., Макух Г.В.,

Влох М.В., Костюченко Л.В.

Синдром "котячого ока" без атрезії ануса, з ампліфікацією генів ADA2

та IL17RA (клінічний випадок)

Хапченкова Д.С., Дубина С.А.

Синдром Sinding-Larsen-Johansson:

обзор литературы и собственное

клиническое наблюдение

\section{ШКОЛА \\ ПРАКТИЧЕСКОГО ВРАЧА}

Крамарьов С.О., Закордонець Л.В.

Застосування розчинів для оральної регідратації у дітей. Методичні рекомендації

Бережний В.В., Бондарець Ю.І.

Порушення мікробіому товстого кишечника та його корекція у хворих на ювенільний ревматоїдний артрит

\section{МЕЖДУНАРОДНЫЕ ПРОТОКОЛЫ, РЕКОМЕНДАЦИИ}

Гострий обструктивний ларингіт (круп) у дітей.

Адаптована клінічна настанова, заснована на доказах

\section{CLINICAL CASE}

53 Chernik-Bulent A.F., Hajiyeva F.F., Mamedova F.M. A rare case of mucopolysaccharidosis type $\mathrm{VI}$ : Maroteaux-Lamy disease (diagnostic errors)

57 Dushar M.I., Akopyan H.R., Makukh G.V. Vloch M.V., Kostyuchenko L.V.

Cat eye syndrome without anal atresia with the amplification of the ADA2 and IL17RA genes, a description of the clinical case

61 Khapchenkova D.S., Dubyna S.A.

Sinding-Larsen-Johansson syndrome: a literature review and own clinical case

\section{PRACTICAL DOCTOR SCHOOL}

65 Kramarov S.O. Zakordonets L.V.

The use of solutions for oral rehydration in children: Guidelines

76 Berezhniy V.V., Bondarets Yu.I. Impaired colon microbiome and its correction in patients with juvenile rheumatoid arthritis

THE INTERNATIONAL CLINICAL PROTOCOLS, RECOMMENDATIONS

\section{Acute obstructive}

laryngitis (croup) in children.

Evidence-based and adapted clinical guidelines

\section{Журнал «Современная педиатрия» реферируется и индексируется}

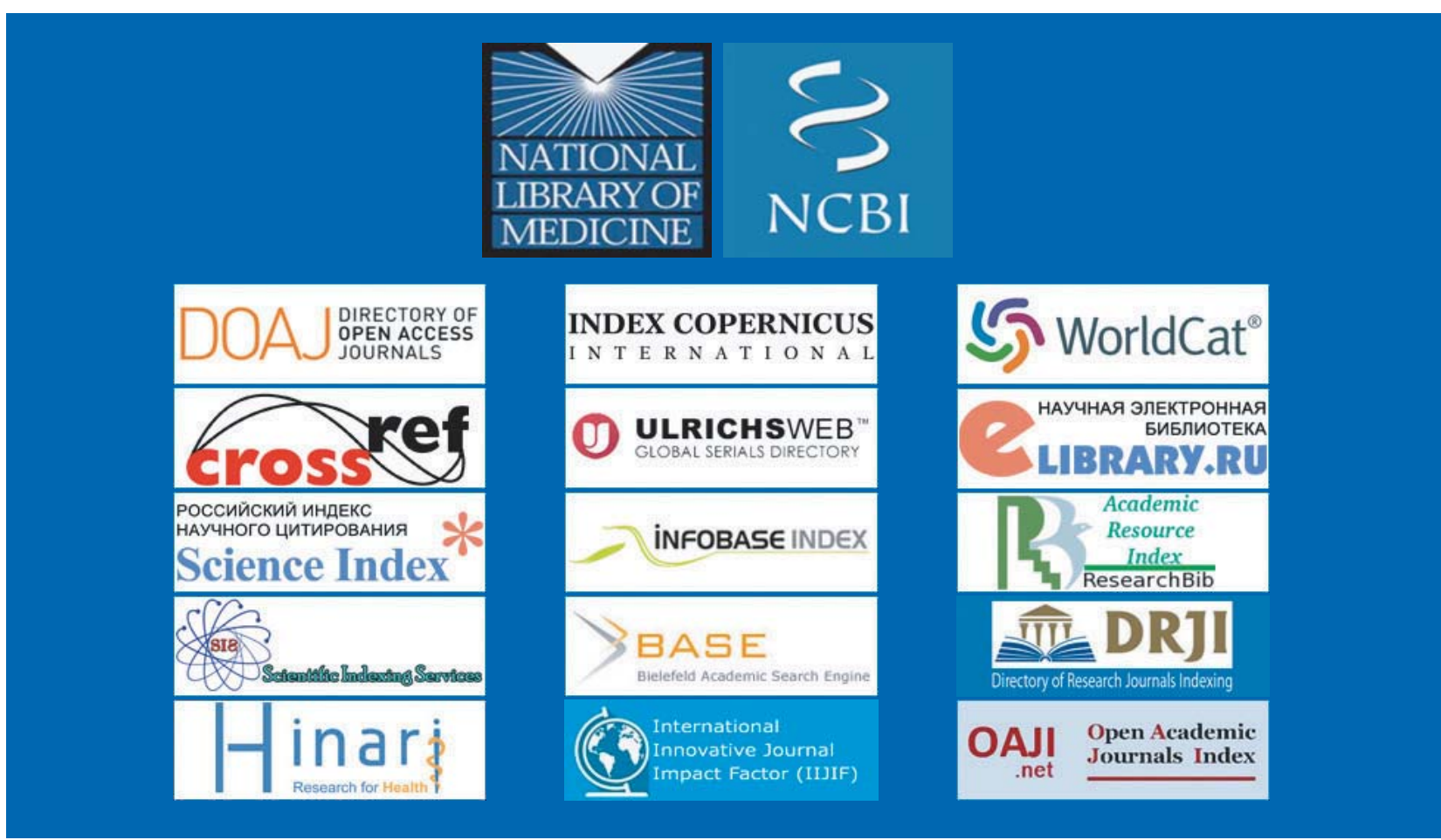




\title{
О.К. Колоскова, С.І. Тарнавська, О.О. Шахова, Н.І. Прунчак Особливості перебігу неускладненої позалікарняної пневмонії у дітей з урахуванням лейкоцитарних індексів крові
}

\author{
ВДНЗУ «Буковинський державний медичний університет», м. Чернівці, Україна
}

\author{
SOVREMENNAYA PEDIATRIYA.2019.2(98):7-11; doi 10.15574/SP.2019.98.7
}

\begin{abstract}
Мета: покращити результати лікування дітей, хворих на позалікарняну пневмонію (ПП), шляхом вивчення діагностичної цінності лейкоцитарних індексів крові як маркерів ризику несприятливого перебігу захворювання.

Матеріали і методи. Проведено комплексне обстеження 72 дітей, хворих на ПП. 3 урахуванням середнього показника індексу зсуву лейкоцитів крові (ІЗЛК) діти були розподілені на дві клінічні групи. І групу склали 28 хворих на ПП дітей, у яких ІЗЛК дорівнював $\geq 2,0$ у.0. (середній вік — 7,8ะ1,6 року,

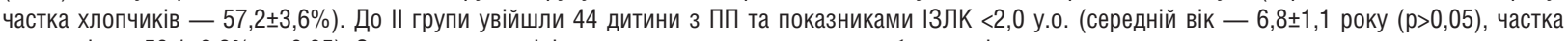

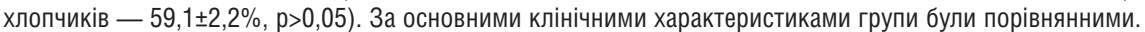

Результати. Перебіг ПП у дітей I групи з виразним зсувом лейкоцитарної форми вліво (ІЗЛК 22 у.о.) частіше асоціював з оцінкою важкості пневмонії $>78$ балів за шкалою PSI, ознаками вогнищево-зливної та сегментарної пневмонії на рентгенограмі, при цьому вірогідність важкого перебігу хвороби зростала у 2,5 разу. У представників I групи відзначали частіший розвиток ускладнень у вигляді ексудативного плевриту, вірогідність розвитку якого зростала у 3,4 разу. Незважаючи на відносно меншу частоту розвитку фебрильної лихоманки у I групі, вона мала триваліший перебіг, а у хворих частіше реєстрували прояви бронхообструктивного синдрому. Натомість у дітей із ПП та ІЗЛК <2 у.0. частіше відмічали вогнищеві форми пневмонії на ренгенограмі, а гострий інфекційно-запальний процес частіше локалізувався на рівні верхніх дихальних шляхів у вигляді гнійного синуситу. Висновки. За наявності виразного показника індексу інтоксикації (ІЗЛК $\geq 2$ у.о.) достовірно у 2,5 разу зростає вірогідність несприятливого перебігу ПП у дітей.
\end{abstract}

Ключові слова: діти, позалікарняна пневмонія, індекс зсуву лейкоцитів крові.

\section{Peculiarities of uncomplicated community-acquired pneumonia in children considering blood leukocytic indices \\ O.K. Koloskova, S.I. Tarnavska, 0.0. Shakhova, H.I. Prunchak \\ HSEE «Bukovinian State Medical University», Chernivtsi, Ukraine}

Objective: to improve the results of treatment of children suffering from community-acquired pneumonia (CAP) by means of studying diagnostic value of the blood leukocytic indices as risk markers of an unfavourable course of the disease.

Materials and methods. 72 children suffering from CAP underwent a comprehensive examination. Considering the mean value of blood leukocyte shift index (BLSI) the children were divided into two clinical groups. I group included 28 children suffering from uncomplicated community-acquired pneumonia with BLSI $\geq 2.0$ standard units (an average age $-7.8 \pm 1.6$ years, including $-57.2 \pm 3.6 \%$ boys). II group included 44 children suffering from uncomplicated community-acquired pneumonia with BLSI $<2.0$ standard units (an average age $-6.8 \pm 1.1$ years $(p>0,05)$, including $-59.1 \pm 2.2 \%$ boys $(p>0.05)$. The groups of the study were comparable by the main clinical characteristics.

Results. The analysis of the data obtained showed that the course of CAP among children of I group with a marked leukocyte formula left shift (BLSI $>2$ standard units) was more frequently associated with severity of community-acquired pneumonia $>78$ points by PSI scale, signs of pneumonia with confluent foci and segmental pneumonia on X-ray films. At the same time, the chances of a severe course of the disease 2.5 times increased reliably. The representatives of I group developed more frequent cases of complications in the form of exudative pleuritis, which chances of development 3.4 times increased.

At the same time patients from I group, in spite of relatively lower frequency of development of febrile fever, developed a longer course of pneumonia, and the signs of bronchial obstructive syndrome were registered more often.

Contrary to children with CAP and BLSI $<2$ standard units, focal forms of pneumonia on X-ray films were found more frequently, and acute infectious-inflammatory process was more often localized on the level of the upper respiratory tract in the form of suppurative sinusitis.

Conclusions. In case of a marked value of intoxication index (leukocyte shift indexi $\geq 2$ standard units) the chances of an unfavourable course of communityacquired pneumonia in children 2.5 times increased.

Key words: children, community-acquired pneumonia, blood leukocyte shift index.

\section{Особенности течения неосложненной внебольничной пневмонии у детей с учетом лейкоцитарных индексов крови Е.К. Колоскова, С.И. Тарнавская, ОА. Шахова, Н.И. Прунчак \\ ВГУЗУ «Буковинский государственный медицинский университет», Черновцы}

Цель: улучшить результаты лечения детей, больных внебольничной пневмонией (ВП), путем изучения диагностической ценности лейкоцитарных индексов крови в качестве маркеров риска неблагоприятного течения заболевания.

Материалы и методы. Проведено комплексное обследование 72 детей, больных ВП. С учетом среднего показателя индекса сдвига лейкоцитов крови (ИСЛК) дети были разделены на две клинические группы. I группу составили 28 больных с ВП и ИСЛК $\geq 2,0$ у.е. (средний возраст $-7,8 \pm 1,6$ года, доля мальчиков $-57,2 \pm 3,6 \%$ ), во II группу вошли 44 ребенка с ВП и показателями ИСЛК $<2,0$ у.е. (средний возраст $-6,8 \pm 1,1$ года $(\mathbf{p}<0,05)$, доля

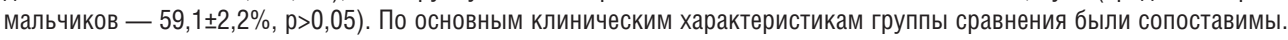

Результаты. Течение ВП у детей I группы с выраженным сдвигом лейкоцитарной формы влево (ИСЛК 22 у.е.) чаще ассоциировал с оценкой тяжести внебольничной пневмонии >78 баллов по шкале PSI, признаками очагово-сливной и сегментарной пневмонии на рентгенограмме, при этом вероятность тяжелого течения болезни увеличивалась в 2,5 раза. У представителей I группы отмечали частое развитие осложнений в виде экссудативного плеврита, шансы развития которого возрастали в 3,4 раза. Несмотря на относительно меньшую частоту развития феебрильной лихорадки у пациентов I группы, она имела длительное течение, а у больных чаще регистрировали проявления бронхообструктивного синдрома. В То же время у детей с ВП и ИСЛК <2 у.е. чаще отмечали очаговые формы пневмонии на рентгенограмме, а острый инсрекционно-воспалительный процесс чаще локализовался на уровне верхних дыхательных путей в виде гнойного синусита.

Выводы. При наличии выраженного показателя индекса интоксикации (индекс сдвига лейкоцитов крови $\geq 2$ у.е.) достоверно в 2,5 раза возрастает вероятность неблагоприятного течения внебольничной пневмонии у детей.

Ключевые слова: дети, внебольничная пневмония, индекс сдвига лейкоцитов крови. 


\section{Вступ}

$\Pi$ озалікарняна пневмонія (ПП) є актуальною проблемою педіатрії, оскільки останніми роками відзначається зростання захворюваності серед дітей, а смертність внаслідок пневмонії є відносно високою [15]. Водночас не вирішеними залишаються найбільш серйозні проблеми - рання діагностика та емпіричний вибір раціональної етіотропної терапії пневмонії у дитячому віці.

Упродовж останніх десятиліть проведена велика кількість клінічних та епідеміологічних досліджень, що стосуються пневмонії. На підставі отриманих даних та виділення окремих фенотипів хвороби назріла необхідність перегляду ряду позицій щодо ведення ПП у дітей відповідно до сучасних клінічних рекомендацій $[3,10]$. Так, прогнозування важкості та особливостей перебігу пневмонії, оцінка потенційних ризиків та результатів лікування ПП у кожному конкретному випадку залишаються не вирішеними [12].

Враховуючи, що загальновідомим патогенетичним механізмом пневмонії є запалення, вивчення ролі факторів системного запалення у якості маркерів оцінки важкості та прогнозу перебігу захворювання $є$ надзвичайно актуальним [14]. Найбільш відомими та вивченими запальними біомаркерами сьогодні вважають сироватковий вміст прокальцитоніну, С-реактивного білка, інтерлейкінів 1, 6, 8, фактору некрозу пухлин, розчинного урокіназного активатора плазміногена, розчинного тромбомодуліну тощо [13]. Як показано рядом робіт, використання біомаркерів запалення додає замало інформації до клінічних та рентгенологічних даних, зокрема при використанні зазначених вище тестів самостійно [7]. Серед традиційних біомаркерів визначення прокальцитоніну наразі видається дослідникам найбільш ефективним як у селекції бактеріального запального процесу, так і в оцінці важкості захворювання [14]. Однак даний маркер не дозволяє остаточно розмежувати бактеріальну та вірусну етіологію ПП і чітко прогнозувати важкі випадки перебігу захворювання, є високовартісним і почасти недоступним хворим на первинному етапі надання допомоги, що визначає необхідність подальших досліджень даного питання [6].

Усе вищенаведене зумовлює необхідність пошуку інформативних і доступних маркерів інфекційно-запального процесу, які могли б використовуватися як для оцінки несприят- ливого перебігу ПП, так і для визначення ризику виникнення ускладнень.

У клінічний практиці більш доступним методом є визначення важкості запального процесу за вмістом циркулюючих гранулоцитів у периферичній крові, зокрема це лейкоцитарні індекси інтоксикації, індекси неспецифічної реактивності та індекси активності запалення [2].

Так, за даними В.Г. Базаракшеева [1] визначено зростання лейкоцитарного індексу інтоксикації (ЛІІ) та індексу зсуву лейкоцитів крові (ІЗЛК) у пацієнтів із гострим апендицитом, особливо за наявності ризику деструкції. Водночас, на думку автора, лише комплексний підхід до інтерпретації лейкоцитарних індексів дозволить оцінити ступінь та прогноз важкості перебігу ендогенної інтоксикації та, відповідно, визначити обсяг лікувальних заходів.

Наведені дані узгоджуються 3 роботою О.М. Рекалової та співавт. [4], які вказують, що підвищення індексу ІЗЛК та індексу співвідношення нейтрофілів та лімфоцитів (ІСНЛ) свідчить про активність хронічного запального процесу та активацію нейтрофілів крові, а підвищення ІЗЛК можна вважати непрямим критерієм важкості функціональних легеневих порушень при ХОЗЛ.

Рядом дослідників запропоновано визначення співвідношення кількості нейтрофілів до лімфоцитів (NLR або ICHЛ) та тромбоцитів до співвідношення лімфоцитів (PLR) у якості показників системного запалення та інфекції $[9,11]$.

Проте у педіатричній практиці дане питання досліджене вкрай недостатньо.

Mema дослідження: покращити результати лікування дітей, хворих на ПП, шляхом вивчення діагностичної цінності лейкоцитарних індексів крові як маркерів ризику несприятливого перебігу захворювання.

\section{Матеріал і методи дослідження}

Для досягнення поставленої мети методом простої випадкової вибірки сформована когорта з 72 дітей, хворих на ПП, які одержували стаціонарне лікування в КМУ «Обласна дитяча клінічна лікарня м. Чернівці». У всіх дітей на підставі результатів гемограми периферичної крові визначали індекс зсуву лейкоцитів крові (ІЗЛК), який розраховували за формулою [4]: $I 3 J K=G R A \% /(M O N \%+L Y M \%)$,

де GRA \% (granulocytes) - відсотковий вміст гранулоцитів у лейкоцитарній формулі 
(сума відсоткового вмісту нейтрофілів, еозинофілів, базофілів);

MON \% (monocytes) - відсотковий вміст моноцитів у лейкоцитарній формулі;

LYM \% (lymphocytes) - відсотковий вміст лімфоцитів у лейкоцитарній формулі.

Значення показника у здорових людей, за даними літератури, у середньому становить від $(1,53 \pm 0,07)$ до $(1,99 \pm 0,15)$ у. о.

Залежно від показника ІЗЛК були сформовані дві клінічні групи. Першу (I) групу склали 28 дітей, у яких ІЗЛК дорівнював $\geq 2,0$ у.о. (середній вік $-7,8 \pm 1,6$ року, частка хлопчиків $57,2 \pm 3,6 \%$ ), до II групи увійшли 44 дитини 3 показниками ІЗЛК $<2,0$ у.о. (середній вік $6,8 \pm 1,1$ року ( $>00,05)$, частка хлопчиків $59,1 \pm 2,2 \%, \mathrm{p}>0,05)$. За основними клінічними характеристиками групи були порівнянними.

У роботі використана класифікація ПП відповідно до протоколу діагностики та лікування пневмоній у дітей, затвердженого наказом МО3 України (№18 від 13.01.2005р.), а також відповідно до міжнародних рекомендацій щодо діагностики та лікування пневмонії у дітей. Оцінку важкості пневмонії при госпіталізації проводили за шкалою PSI (Pneumonia Severity Index) за Fine та співавт. (1997) [3]. Оцінку інтенсивності кашлю проводили за вербальною дескриптивною шкалою оцінки кашлю [8].

Верифікацію діагнозу здійснювали на підставі даних анамнезу, типової клінічної картини захворювання, лабораторного обстеження (клінічного аналізу крові, біохімічного аналізу крові, імунологічного дослідження), бактеріологічного дослідження мазків із зіва та носа, мокротиння, рентгенологічного дослідження.

Вивчення складу периферичної крові проводили 3 використанням гематологічного аналізатора Elite 3, що дозволяє отримати 22 параметри із автоматизованим підрахунком у венозній крові хворих кількості лейкоцитів (WBC), абсолютної та відносної кількості лімфоцитів (LYM ABS, LYM \%), моноцитів (MON ABS, MON \%), гранулоцитів (GRA ABS, GRA \%), що включали сумарну кількість нейтрофілів, еозинофілів, базофілів.

Одержані результати дослідження аналізували з позицій біостатистики та клінічної епідеміології за допомогою комп'ютерних пакетів Statistica7 StatSoft Inc. та Excel XР для Windows, різницю показників вважали статистично значущою за $\mathrm{p}<0,05$.

Відбір та обстеження пацієнтів відповідали принципам біомедичної етики в педіатрії.

\section{Результати дослідження та їх обговорення}

Ознаки гострих респіраторних вірусних захворювань на догоспітальному етапі спостерігали у 78,6\% дітей I групи та у 86,3\% (p $\varphi>0,05)$ представників II групи.

Прояви гострого синуситу майже вдвічі частіше траплялися у дітей II клінічної групи (50,0\%) порівняно з представниками I клінічної групи $-21,4 \%(p \varphi<0,05)$. Відносний ризик розвитку гострого синуситу у пацієнтів II групи порівняно з представниками I клінічної групи дорівнював - 2,3 [95\% ДI: 1,8-3,1], при співвідношенні шансів - 3,7 [95\% ДІ: 2,0-6,9], що дозволяє використовувати ІЗЛК $\geq 2$ у.о. як критерій виключення гострого синуситу у хворих на ПП дітей.

Клінічна оцінка особливостей перебігу ПП у дітей груп спостереження дозволила встановити, що серед пацієнтів I клінічної групи вірогідно частіше переважали хворі із вогнищевозливною формою ПП $(14,3 \%)$, ніж серед пацієнтів II клінічної групи $(4,5 \%$; р $<<0,05)$, та сегментарною клініко-рентгенологічною формою пневмонії $(21,4 \%$ і $9,1 \%$ відповідно $p \varphi<0,05)$. За частотою реєстрації вогнищевої пневмонії у групах спостереження не відмічено вірогідних відмінностей, частка даної форми ПП становила 64,3\% і 86,4\% у I та II клінічніх групах відповідно (р甲>0,05). Ексудативний плеврит реєстрували у $14,2 \%$ I групи та лише

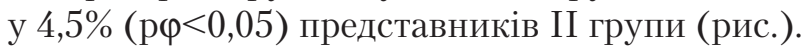

Показники ризику ускладнення ПП ексудативним плевритом у хворих на ПП за наявності ІЗЛК $\geq 2$ у.о. дорівнювали: відносний ризик 3,1 [95\% ДІ 2,3-4,2] при співвідношенні шансів 3,4 [95\% ДІ :1,1-10,4].

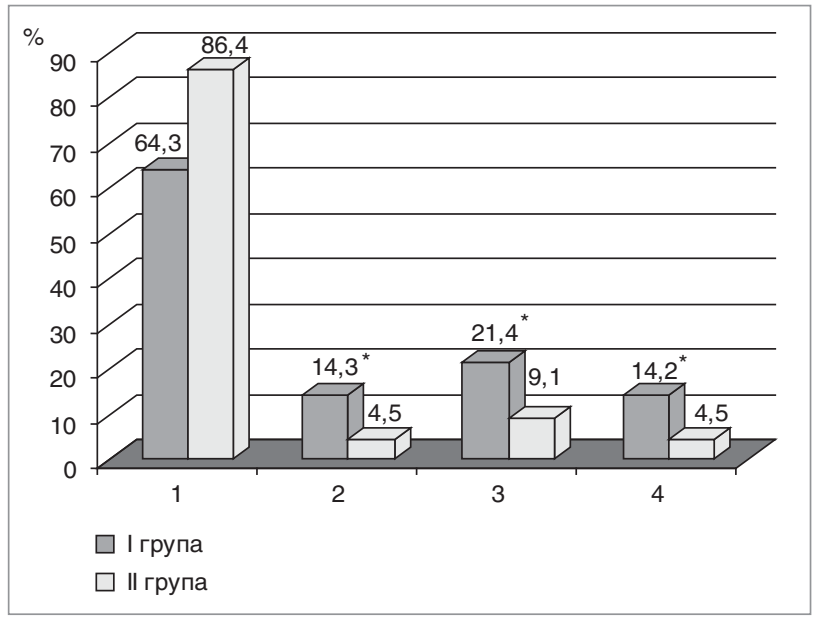

Примітка: 1 - частка пацієнтів (\%) із вогнищевою пневмонією, 2 - частка пацієнтів (\%) із вогнищево-зливною пневмонією, 3 - частка пацієнтів (\%) із сегментарною пневмонією, 4 - частка пацієнтів (\%) з ексудативним плевритом, * - достовірні відмінності.

Pис. Рентгенологічні зміни у пацієнтів груп порівняння 
Під час оцінки важкості пневмонії за шкалою PSI (Pneumonia Severity Index) нами не виявлено вірогідних відмінностей щодо важкості пневмонії у I та II клінічних групах, яка становила

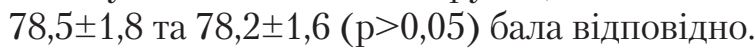

Водночас частка дітей, у яких індекс важкості ПП (PSI) у 1-й день госпіталізації перевищував 78 балів, серед пацієнтів I групи виявилася вдвічі більшою $(42,9 \%)$, а серед представників II клінічної групи - лише $22,8 \%$ $(\mathrm{p}<0,05)$. Показники ризику реєстрації PSI>78 балів на початку стаціонарного лікування у пацієнтів з ПП за ІЗЛК $\geq 2$ у.о. дорівнювали: відносний ризик - 1,5 [95\% ДI: 1,0-2,3] при співвідношенні шансів 2,5 [95\% ДI: $1,4-4,7]$.

Індекс важкості пневмонії у пацієнтів I клінічної групи вірогідно корелював із віком пацієнтів $(\mathrm{r}=0,8, \mathrm{p}<0,05)$, а також тривалістю лихоманки $(\mathrm{r}=0,9, \mathrm{p}<0,05)$. Водночас у пацієнтів II клінічної групи встановлено вірогідні прямі кореляційні зв'язки індексу важкості пневмонії 3 інтенсивністю кашлю $(\mathrm{r}=0,9$, $\mathrm{p}<0,05)$ та виразністю рентгенологічних змін $(\mathrm{r}=0,6, \mathrm{p}<0,05)$.

Виразні ознаки інтоксикації поряд із підвищенням температури тіла понад $38,5^{\circ} \mathrm{C}$ реєстрували у 50\% хворих II групи та лише у $36,4 \%$

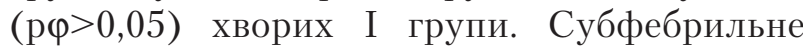
підвищення температури $\left(37,2-38,0^{\circ} \mathrm{C}\right)$ визначалось у 42,8\% пацієнтів I групи та у $18,2 \%$ $(\mathrm{p} \varphi 0,05)$ хворих II групи. Фебрильна лихоманка (понад $38,1^{\circ} \mathrm{C}$ ) також частіше реєструвалась у пацієнтів II групи (81,8\% дітей) та лише у $57,2 \%(p \varphi<0,05)$ пацієнтів I клінічної групи.

У середньому тривалість лихоманки у пацієнтів I групи дорівнювала 4,9 доби, а в пацієнтів II групи - 4,1 доби. Частка хворих, у яких тривалість лихоманки перевищувала 4 доби, серед пацієнтів I групи склала $57,2 \%$, а серед представників II групи - 36,4\% $(\mathrm{p} \varphi 0,05)$. Таким чином, незважаючи на відносно меншу частку хворих I групи, які високо лихоманять, тривалість фебрилітету у них є вірогідно більшою.

Показники ризику реєстрації тривалої лихоманки $\left(38,5^{\circ} \mathrm{C}\right.$ понад чотири доби) у хворих на ПП за наявності ІЗЛК $\geq 2$ у.о. дорівнювали: відносний ризик - 1,5 [95\% ДI: 1,1-2,1] при співвідношенні шансів 2,3 [95\% ДІ: 1,3-4,1].

При подальшому об'єктивному обстеженні встановлено, що при надходженні до стаціонаpy $50,0 \%$ та $13,6 \%(p \varphi<0,05)$ дітей I та II групи відповідно скаржилися на сухий кашель, а малопродуктивний кашель визначали у 50,0\%

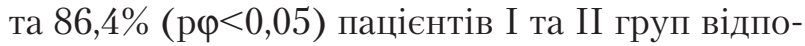
відно. Перкуторно в усіх дітей визначалося притуплення над ураженою ділянкою легень. При аускультації в усіх хворих вислуховувалося жорстке, місцями ослаблене, дихання, у 50,0\% та $13,6 \%(p \varphi<0,05)$ дітей I та II груп відповідно при госпіталізації визначались сухі хрипи та у $42,8 \%$ та $72,7 \%(p \varphi<0,05)$ пацієнтів - вологі дрібнопухирчасті крепітуючі хрипи.

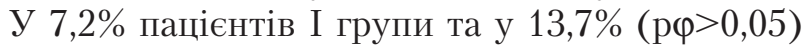
II групи хрипи вислухати не вдалося.

Слизово-гнійне харкотиння реєстрували

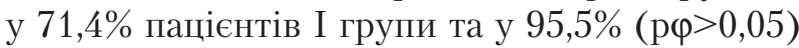
II групи; гнійне харкотиння реєстрували у 28,6\% хворих I групи та лише у 4,5\% $(\mathrm{p} \varphi<0,05)$ II групи.

Ознаки дихальної недостатності (ДН) I ступеня визначали у 71,4\% пацієнтів I групи та у $90,9 \% \quad(p \varphi>0,05)$ хворих II групи. Ознаки дихальної недостатності II ступеня траплялися втричі частіше у хворих із виразними ознаками запалення (28,6\% пацієнтів I групи) та лише у $9,1 \% \quad(p \varphi<0,05)$ представників II клінічної групи. Показники ризику реєстрації ДН ІІ ступеня у хворих на ПП за наявності ІЗЛК $\geq 2$ у.о. дорівнювали: відносний ризик - 1,7 [95\% ДI: 0,8-3,4] при співвідношенні шансів 4,0 [95\% ДІ: $1,8-8,9]$.

У половини пацієнтів I групи (50\%) клінічні особливості перебігу ПП включали ознаки бронхообструктивного синдрому (БОС), на відміну від пацієнтів II клінічної групи, де про-

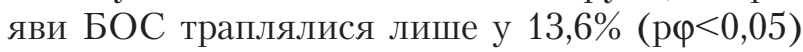
хворих. Показники ризику наявності БОС у хворих на ПП за наявності ІЗЛК $\geq 2$ у.о. дорівнювали: відносний ризик - 2,1 [95\% ДІ: 1,3-3,6] при співвідношенні шансів 6,4 [95\% ДI: $3,2-12,7]$.

Супутні прояви у вигляді малих аномалій розвитку серця (пролапси клапанів) реєстрували у $28,6 \%$ пацієнтів I групи та у 9,0\% (p $\varphi<0,05)$ представників II групи.

Таким чином, перебіг ПП у дітей із зсувом лейкоцитарної формули вліво (ІЗЛК $\geq 2$ у.о.) частіше асоціював 3 оцінкою важкості пневмонії >78 балів за шкалою PSI, ознаками вогнищево-зливної та сегментарної пневмонії на рентгенограмі, при цьому вірогідність важкого перебігу хвороби зростали у 2,5 разу. У дітей I групи частіше визначали розвиток ускладнень у вигляді ексудативного плевриту, що загалом збігається з даними літератури [5]. У цієї категорії пацієнтів, незважаючи на від- 
носно меншу частоту розвитку фебрильної лихоманки, вона мала триваліший перебіг, а у хворих частіше реєстрували прояви БОС та супутніх малих аномалій серця.

Натомість у дітей з ПП та ІЗЛК <2 у.о. частіше відмічали вогнищеві форми пневмонії, а гострий інфекційно-запальний процес частіше локалізувався на рівні верхніх дихальних шляхів у вигляді гнійного синуситу.

\section{Висновки}

1. У дітей із виразним зсувом лейкоцитарної формули вліво (ІЗЛК $\geq 2$ у.о.) частіше реєстрували вогнищево-зливні та сегментарні пневмонії, при цьому вірогідність несприятливого перебігу хвороби зростала у 2,5 разу.

2. У пацієнтів із високими показниками індексу інтоксикації (ІЗЛК $\geq 2$ у.о.) шанси розвитку бронхообструктивного синдрому зростали у 6,4 разу.

3. Перебіг ПП у дітей із показниками ІЗЛК $\geq 2$ у.о. часто асоціював з ознаками виразної дихальної недостатності, вірогідність розвитку якої зростала у 4,0 рази.

4. Показники ризику розвитку ексудативного плевриту у хворих на ПП за наявності ІЗЛК $\geq 2$ у.о. дорівнювали: відносний ризик 3,1 [95\% ДІ: 2,3-4,2] при співвідношенні шансів 3,4 [95\% ДІ: 1,1-10,4].

Перспективи подальших досліджень полягають у пошуку інформативних та доступних маркерів інфекційно-запального процесу, які могли б використовуватися для оцінки несприятливого перебігу ПП у дітей.

Автори заявляють про відсутність конфлікmу інтересів.

\section{ЛITЕРАТУРА}

1. Банзаракшеев ВГ. (2010). Лейкоцитарные индексы как способ оценки эндогенной интоксикации организма. Бюллетень ВСНЦ СО PAMH. 3(73): 390-391.

2. Годлевський Al, Саволюк Cl. (2015). Діагностика та моніторинг ендо токсикозу у хірургічних хворих: монографія. Вінниця: Нова Книга: 232.

3. Майданник ВГ, Ємчинська ЄО. (2014). Клінічні настанови з діагностики та лікування позалікарняної пневмонії у дітей з позиції доказової медицини. Київ: 43.

4. Рекалова ОМ, Панасюкова ОР, Коваль НГ. (2017). Застосування лейкоцитарних індексів при імунологічній оцінці активності запального процесу у хворих на хронічне обструктивне захворювання легень. Астма та алергія. 1: 27-33.

5. Blot M, Croisier D, P?chinot A et al. (2018). A Leukocyte Score to Improve Clinical Outcome Predictions in Bacteremic Pneumococcal Pneumonia in Adults/ Open Forum Infectious Diseases. https://academic.oup.com/ofid/article-abstract/1/2/ofu075/1467923

6. Curbelo J, Bueno SL, Galva'n-Roma'n JM et al. (2017). Inflammation biomarkers in blood as mortality predictors in community-acquired pneumonia admitted patients: Importance of comparison with neutrophil count percentage or neutrophil-lymphocyte ratio. PLoS ONE. 12(3):1234-1242.

7. Harris M, Clark J, Coote $\mathrm{N}$ et al. (2011). Guidelines for the management of community acquired pneumonia in children: update 2011. Thorax. 66:1-23.

8. Hsu JY, Stone RA, Logan-Sinclair RB et al. (1994). Coughing frequency in patients with persistent cough: assessment using a 24 hour ambulatory recorder. Eur Respir J. 7:1246-1253.

9. Hwang SY, Shin TG, Jo IJ et al. (2017). Neutrophil-tolymphocyte ratio as a prognostic marker in critically-ill septic patients. Am J Emerg Med 35: 234-239.

10. Infants and Children: Acute Management of Community Acquired Pneumonia. Guideline. GL2018_007. 16 March 2018: 38.

11. Kartal O, Kartal AT. (2017). Value of neutrophil to lymphocyte and platelet to lymphocyte ratios in pneumonia. Bratisl Med J. 118; 9:513-516.

12. le Roux DM, Zar HJ. (2017). Community-acquired pneumonia in children - a changing spectrum of disease. Pediatr. Radiol. 47:1392-1398.

13. Lippi G, Meschi T, Cervellin G. (2011). In?ammatory biomarkers for the diagnosis, monitoring and follow-up of community-acquired pneumonia: Clinical evidence and perspectives. Eur J Intern Med. 22:460-465

14. Principi N, Esposito S. (2017). Biomarkers in Pediatric CommunityAcquired Pneumonia. Int J Mol Sci. 18: 447-456.

15. Restrepo MI, Faverio P, Anzueto A. (2013). Long-term prognosis in community-acquired pneumonia. Curr Opin Infect Dis. 26(2): 151-158.

\section{Сведения об авторах:}

Колоскова Елена Константиновна - д.мед.н., проф., зав. каф. педиатрии и детских инфекционных болезней ВГУзУ «Буковинский государственный медицинский университет Адрес: г. Черновцы, ул. Русская, 207А; тел. (0372) 575-660.

Тарнавская Светлана Ивановна - К.мед.н., доц. каф. педиатрии и детских инфекционных болезней ВГУзУ «Буковинский государственный медицинский университет».

Адрес: Г. Черновиы, үл. Русская, 207А; тел. (0372) 575 -600.

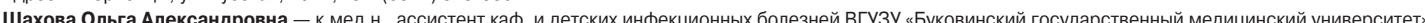

Адрес: г. Черновцы, ул. Русская, 207А; тел. (0372) 575-660.

Прунчак Наталья Ивановна - преподаватель Черновицкого медицинского колледжа ВГУзу «Буковинский государственный медицинский университет».

Адрес: г. Черновцы, ул. Котляревского, 5/13.

Статья поступила в редакцию 26.11.2018 г.; принята в печать 28.02.2019 г. 


\title{
Л.А. Шаповал, А.К. Куркевич \\ Роль фетальної ехокардіографії у визначенні прогнозу для плода з повною атріовентрикулярною комунікацією
}

\author{
ДУ «Науково-практичний медичний центр дитячої кардіології та кардіохірургії МОЗ України», м. Київ, Україна
} SOVREMENNAYA PEDIATRIYA.2019.2(98):12-17; doi 10.15574/SP.2019.98.12

\begin{abstract}
Атріовентрикулярна комунікація (АВК) об'єднує групу вроджених вад серця зі спільним атріовентрикулярним (АВ) з'єднанням внаслідок аномального розвитку структур, що є похідними від ендокардіальних подушечок під час ембріонального розвитку серця. Дана вада характеризується аномальною

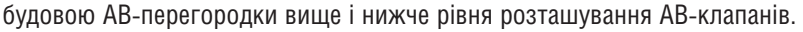

Пренатальна діагностика АВК є дуже важливою, оскільки при даній ваді часто зустрічаються хромосомні аномалії. Крім того, можлива асоціація 3 іншими серцевими та позасерцевими вадами розвитку.

Мета - визначити частоту поєднання хромосомних, додаткових серцевих та позасерцевих аномалій у плодів з діагнозом АВК та проаналізувати їх вплив на клінічний перебіг вади у пре- та постнатальному періоді.

Матеріали і методи. Із січня 2014 р. по грудень 2017 р. у відділенні пренатальної діагностики «ДУ НПМЦДКК МОЗ України» обстежено 4343 вагітних. Під час проведення фетальної ехокардіографії у 1247 плодів діагностовано вроджені вади серця, 215 (17,2\%) 3 яких мали АВК. Проаналізовано дані фетальної ехокардіографії у плодів з АВК з порівнянням плодів з анеуплоїдією та без неї.

Результати. АВК діагностована у 215 плодів та підтверджена у 120 новонароджених. Середній вік матері склав 29,9ะ5,4 року (діапазон 17-46). Середній період гестації становив 24,7士4,9 тижня (діапазон 17-39). Каріотип плода на момент первинної консультації був відомий у 45 (20,9\%) випадках, анеуплоїдія діагностована у 30 (14\%) плодів. АВК без будь-яких інших внутрішньосерцевих вад розвитку була у $111(51,6 \%)$ плодів. Позасерцеві аномалії були виявлені у $104(48,3 \%)$ плодів. у 87 (40,5\%) випадках відбулося переривання вагітності. 120 (55,8\%) вагітностей закінчились строковими пологами та 8 (3,7\%) - внутрішньоутробною загибеллю плода. Із восьми випадків внутрішньоутробної загибелі плода у чотирьох була діагностована комбінована АВК, у решти - ізольована АВК. Із 120 народжених живими 63(28,8\%) немовлят померли в неонатальному періоді без хірургічного втручання. Достовірно встановлено, що лише 57 (26,5\%) пацієнтам проведено хірургічне лікування $(\mathrm{p}=0,001) .3215$ плодів з пренатально діагностованою АВК хромосомна патологія виявлена у 66 (30,7\%) новонароджених, 63 (29,3\%) 3 яких мали синдром Дауна, що є статистично достовірним $(\mathrm{p}=0,001)$

Загальна виживаність протягом трирічного періоду спостереження склала для пацієнтів з ізольованою АВК 27,9\%, для пацієнтів з комбінованою ABK $-15,4 \%$.
\end{abstract}

Висновки. Розуміння впливу екстракардіальних та хромосомних аномалій на фізіологію плода з АВК, знання ризику додаткових серцевих вад для якості життя дитини після народження та володіння можливим потенціалом їх усунення значно підвищують ефрективність пренатальної діагностики у визначенні прогнозу для плода з АВК.

Ключові слова: атріовентрикулярна комунікація, пренатальна діагностика, фетальна ехокардіографія.

\section{The Role of Fetal Echocardiography in Determining the Prognosis for the Fetus with Complete Atrioventricular Septal Defect \\ L.A. Shapoval, A.K. Kurkevich}

$\mathrm{PI}$ «Scientific-practical medical center for pediatric cardiology and cardio surgery» Ministry of health of Ukraine

Atrioventricular septal defect (AVSD) combines a group of congenital heart defects with a common atrioventricular (AV) junction due to the abnormal development of structures that derive from endocardial cushions during embryonic development of the heart. This defect is characterized by abnormal structure of the AV-septation above and below the level of the AV-valves location.

Prenatal diagnosis of AVSD is very important, since in case of such defects chromosomal abnormalities are very common. In addition, a possible association with other cardiac and extracardiac anomalies is possible.

The aim is to determine the frequency of the combination of chromosomal, additional cardiac and extracardiac anomalies in fetuses diagnosed with AVSD; and to analyze their impact on the clinical outcome of defects in the pre- and postnatal period.

Materials and methods. 4,343 pregnant women were examined in the department of prenatal diagnostics of the State Institution «Scientific and Practical Medical Center of Pediatric Cardiology and Cardiac Surgery of the Ministry of Health of Ukraine» from January 2014 to December 2017. During fetal echocardiography 1,247 fetuses were diagnosed with congenital heart defects, $215(17.2 \%)$ of which had AVSD. The data of fetal echocardiography have been analyzed in fetuses with AVSD in comparison with that of fetuses with and without aneuploidy.

Results. AVSD was diagnosed in $215(17.2 \%)$ fetuses and confirmed in $120(55.8 \%)$ newborns. The average age of mothers was $29.9 \pm 5.4$ years (in range of 17-46 years). The average gestation period was $24.7 \pm 4.9$ weeks (in range of 17-39 weeks). Fetal cariotype was known in 45 (20.9\%) cases, aneuploidy was diagnosed in $30(14 \%)$ of fetuses at the time of primary consultation. AVSD without any other intracardiac abnormalities was found in $111(51.6 \%)$ fetuses. Extracardiac abnormalities were found in $104(48.3 \%)$ fetuses. In $87(40.5 \%)$ cases abortion took place. $120(55.8 \%)$ of pregnancies ended in childbirth and $8(3.7 \%)$ in intrauterine fetal death. Out of the eight cases of intrauterine fetal death, in four cases combined AVSD was diagnosed, in other four cases - isolated AVSD. Out of 120 newborns born alive, 63(28.8\%) newborns died during the neonatal period without surgical intervention. It was established that only $57(26.5 \%)$ patients underwent surgery $(p=0.001)$. Out of the 215 fetuses with prenatally diagnosed AVSD, chromosomal pathology was found in $66(30.7 \%)$ newborns, $63(29.3 \%)$ of which had Down syndrome, which is statistically significant $(\mathrm{p}=0.001)$.

The overall survival rate during the three year follow-up period was $27.9 \%$ for patients with isolated AVSD, and $15.4 \%$ for patients with combined AVSD. Conclusions. Understanding the influence of extracardiac and chromosomal abnormalities on fetal physiology with AVSD, awareness of the risk of additional cardiac defects and their impact on the quality of life of the child after birth, as well as of the potential for their elimination, both significantly increase the efficiency of prenatal diagnosis in determining the prognosis for the fetus with AVSD.

Key words: atrioventricular septal defect; prenatal diagnosis; fetal echocardiography. 


\section{Роль фетальной эхокардиографии в составлении прогноза для плода с полной атриовентрикулярной коммуникацией Л.А. Шаповал, А.К. Куркевич}

ГУ «Научно-практический медицинский центр детской кардиологии и кардиохирургии МЗ Украины», г. Киев, Украина

Атриовентрикулярная коммуникация (АВК) объединяет группу врожденных пороков сердца с общим атриовентрикулярным (АВ) соединением вследствие аномального развития структур, производных от эндокардиальных подушечек во время эмбрионального развития сердца. Данный порок характеризуется аномальным строением AB-перегородки выше и ниже уровня размещения АВ-клапанов.

Пренатальная диагностика АВК очень важна, поскольку при данном пороке часто встречаются хромосомные аномалии. Кроме того, возможна ассоциация с другими сердечными и внесердечными пороками развития.

Цель - определить частоту сочетания хромосомных, дополнительных сердечных и внесердечных аномалий у плодов с диагнозом АВК и проанализировать их влияние на клиническое течение порока в пре- и постнатальном периоде.

Материалы и методы. С января 2014 г. по декабрь 2017 г. в отделении пренатальной диагностики ГУ «НПМЦДКК МЗ Украины» обследованы 4343 беременные. Во время проведения фетальной эхокардиограсрии у 1247 плодов диагностированы врожденные пороки сердца, 215 (17,2\%) из которых имели ABK. Проанализированы данные фетальной эхокардиографии у плодов с АВК в сравнении с плодами с анеуплоидией и без нее. Результаты. АВК диагностирована у 215 плодов и подтверждена у 120 новорожденных. Средний возраст матери составил $29,9 \pm 5,4$ года (диапазон

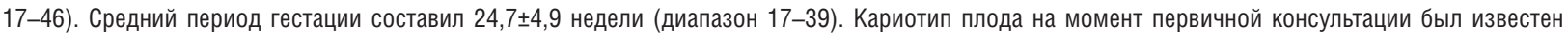
в $45(20,9 \%)$ случаях, анеуплоидия диагностирована у 30 (14\%) плодов. АВК без каких-либо других внутрисердечных пороков развития была у 111 $(51,6 \%)$ плодов. Внесердечные аномалии обнаружены у 104 (48,3\%) плодов. В 87 (40,5\%) случаях произошло прерывание беременности. 120 (55,8\%) беременностей закончились родами в срок и 8 (3,7\%) - внутриутробной гибелью плода. Из восьми случаев внутриутробной гибели плода в четырех была диагностирована комбинированная АВК, в остальных - изолированная АВК. Из 120 живорожденных 63 (28,8\%) младенца умерли в неонатальном периоде без хирургического вмешательства. Достоверно установлено, что только 57 (26,5\%) пациентам проведено хирургическое лечение ( $p=0,001)$. Из 215 плодов с пренатально диагностированной АВК хромосомная патология выявлена у 66 (30,7\%) новорожденных, 63 (29,3\%) из которых имели синдром Дауна, что статистически достоверно $(\mathrm{p}=0,001)$.

Общая выживаемость в течение трехлетнего периода наблюдения составила для пациентов с изолированной АВК 27,9\%, для пациентов с комбинированной $\mathrm{ABK}-15,4 \%$.

Выводы. Понимание влияния экстракардиальных и хромосомных аномалий на физиологию плода с АВК, знание риска дополнительных сердечных пороков для качества жизни ребенка после рождения и владение возможным потенциалом их устранения значительно повышают эффективность пренатальной диагностики в определении прогноза для плода с АВК.

Ключевые слова: атриовентрикулярная коммуникация, пренатальная диагностика, фетальная эхокардиография.

\section{Вступ}

А тріовентрикулярна комунікація (АВК) ооб'єднує групу вроджених вад серця (BВC) зі спільним атріовентрикулярним (AB) з'єднанням внаслідок аномального розвитку структур, що є похідними від ендокардіальних подушечок, під час ембріонального розвитку серця. Дана вада характеризується аномальною будовою АВ-перегородки вище i нижче рівня розташування АВ-клапанів. Наслідком таких анатомічних змін є не тільки порушення цілісності перегородок, але й неправильне формування AB-клапанів та геометрії шлуночків [4].

Атріовентрикулярна комунікація зустрічається 3 частотою від 0,33 до 0,51 на 1000 народжених живими [5], проте є однією з найбільш поширених ВВС, що діагностується пренатально. У дослідженні Evelina fetal АВК склала 16\% у серії пренатально діагностованих ВВС за останні 10 років.

Основним критерієм діагностики АВК під час проведення фетальної Ехо-КГ є аномальне 4-камерне зображення серця у вигляді спільного AB-з'єднання та спільного АВ-клапана.

Пренатальна діагностика АВК є дуже важливою, оскільки при даній ваді часто зустрічаються хромосомні аномалії, серед яких синдром Дауна становить майже 50\% випадків [3]. Крім того, можлива асоціація з іншими серцевими та позасерцевими вадами розвитку $[1,4]$.

Mema роботи - визначити частоту поєднання хромосомних, додаткових серцевих та позасерцевих аномалій у плодів з діагнозом АВК та проаналізувати їх вплив на клінічний перебіг вади у пре- та постнатальному періодах.

\section{Матеріал і методи дослідження}

Із січня 2014 р. по грудень 2017 р. у відділенні пренатальної діагностики «ДУ НПМЦДКК МО3 України» обстежено 4343 вагітних. Під час проведення фетальної Ехо-КГ у 1247 плодів діагностовано ВВС, 215 (17,2\%) з яких мали АВК. Ми проаналізували дані фетальної Ехо-КГ у плодів з АВК, порівнюючи плоди з анеуплоїдією та без неї.

Комплексне трансабдомінальне УЗД серця та великих судин у плодів проводили на УЗ-апаратах фірми Philips (Philips Ultrasound, Bothell, WA) i U22 та EPIQ 7 за допомогою конвексних датчиків C5-1 або С9-2, з частотою 1-5 МГц або 2-9 МГц. Комплексне трансторакальне ЕхоКГ-обстеження дітей проводили на У3-апаратах Philips IE33 із застосуванням у новонароджених фазованих секторних дат- 
чиків S12-10 з частотою 10-12 МГц, у дітей старше місяця - S8-3, з частотою 3-8 МГц.

Усім плодам було проведено двовимірну, кольорову та імпульсну допплерівську Ехо-КГ. М-режим двовимірної Ехо-КГ використовували у випадках порушень серцевого ритму у плода.

Діагноз АВК встановлювали за наявності наступних Ехо-КГ-критеріїв:

1. Візуалізація спільного АВ-з'єднання у вигляді великого отвору посередині серця та відсутність так званого «хреста» серця у 4-камерній проекції.

2. Лінійне (недиференційоване) розташування АВ-клапанів у 4-камерній проекції.

3. Візуалізація спільного АВ-клапана у проекції по короткій осі ЛШ.

4. Наявність притічного дефекту міжшлуночкової перегородки та відсутність первинної міжпередсердної перегородки у 4-камерній проекції.

5. Зображення подовженого та звуженого вихідного тракту лівого шлуночка у 4-камерній проекції внаслідок аномального розташування кореня аорти.

Комбінованою АВК вважали в тих випадки, коли дана вада у плода поєднувалась 3 додатковими вадами серця і судин, за їх відсутності АВК визначалась як ізольований варіант патології. У випадках з відносно рівними розмірами шлуночків ваду класифікували як збалансова-

Демографічні дані обстежених вагітних $(\mathbf{n}=215)$

\begin{tabular}{|l|r|c|c|}
\hline \multicolumn{2}{|r|}{ Плід } & \multicolumn{2}{|c|}{ Каріотип плода } \\
\cline { 3 - 4 } Характеристика & $\begin{array}{c}\text { нормальний } \\
\mathbf{1 5}(\mathbf{7 \%})\end{array}$ & $\begin{array}{c}\text { аномальний } \\
\mathbf{3 0 ~ ( 1 4 \% )}\end{array}$ \\
\hline $\begin{array}{c}\text { Середній } \\
\text { материнський } \\
\text { вік (роки) }\end{array}$ & $30,6 \pm 7,0$ & $26,5 \pm 2,3$ & $31,6 \pm 3,5$ \\
\hline $\begin{array}{c}\text { Середній } \\
\text { термін } \\
\text { гестації (тижні) }\end{array}$ & $24,7 \pm 4,2$ & $22,7 \pm 2,4$ & $21,4 \pm 2,1$ \\
\hline
\end{tabular}

Показання для проведення фетальної ехокардіографії ( $n=215)$

\begin{tabular}{|l|c|c|}
\hline \multicolumn{1}{|c|}{ Дані попередніх обстежень } & Абс. & \% \\
\hline Аномальний 4-камерний зріз серця & 98 & 45,6 \\
\hline Тетрада Фалло & 31 & 14,4 \\
\hline Синдром гіпоплазії лівих відділів серця & 28 & 13,0 \\
\hline $\begin{array}{l}\text { Високий ризик хромосомної } \\
\text { патології у плода під час проведення } \\
\text { першого скринінгу }\end{array}$ & 24 & 11,2 \\
\hline Позасерцева патологія у плода & 22 & 10,2 \\
\hline Сімейна історія ВВС & 8 & 3,7 \\
\hline Цукровий діабет у матері & 4 & 1,9 \\
\hline Разом & 215 & 100 \\
\hline
\end{tabular}

ну. При незбалансованій АВК з домінуванням правого шлуночка визначався істотно менший розмір лівого шлуночка, а при домінуванні лівого шлуночка розміри правого шлуночка були значно меншими. Лівопередсердний ізомеризм діагностували на підставі перериву нижньої порожнистої вени з ії продовженням у напівнепарну вену та/або за наявності повної АВ-блокади у плода з АВК та вісцерокардіальною гетеротаксією (шлунок розташований контрлатерально верхівці серця, печінка посередині). Характерними ознаками правопередсердного ізомеризму була складна комбінація внутрішньосерцевих вад розвитку з повною АВК та вісцерокардіальною гетеротаксією.

Особливості анатомії серця були визначені за даними пренатальних та постнатальних Ехо-КГ-досліджень. Для підтвердження синдрому гетеротаксії після народження дитини додатково виконували КТ на 16-зрізовому томографі Siemens Somatom Sensation. Позасерцеві аномалії та синдроми були діагностовані або підтверджені суміжними спеціалістами (дитячий хірург, дитячий невролог, генетик).

Каріотипування плода рекомендували проводити в усіх випадках, де він був невідомий на момент первинної консультації, акцентуючи увагу на тому, що наявність множинних вад

Супутні внутрішньосерцеві аномалії

Таблиия 3 у плода з АВК $(n=104)$

\begin{tabular}{|l|c|c|}
\hline \multicolumn{1}{|c|}{ Серцева аномалія } & $\begin{array}{c}\text { Кількість } \\
\text { випадків, } \\
\text { абс. }\end{array}$ & $\%$ \\
\hline $\begin{array}{l}\text { Додаткова ліва верхня порожниста } \\
\text { вена, що дренується в розширений } \\
\text { коронарний синус }\end{array}$ & 56 & 26,0 \\
\hline Подвійний вихід з правого шлуночка & 54 & 25,1 \\
\hline Коарктація аорти & 39 & 18,1 \\
\hline Тетрада Фалло & 26 & 12,1 \\
\hline $\begin{array}{l}\text { Транспозиція великих артерій + } \\
\text { Атрезія легеневої артерії + Тотальний } \\
\text { аномальний дренаж легеневих вен }\end{array}$ & 23 & 9,8 \\
\hline Правостороння дуга аорти & 14 & 6,5 \\
\hline Атрезія легеневої артерії & 12 & 5,6 \\
\hline $\begin{array}{l}\text { Множинні десекти } \\
\text { міжшлуночкової перегородки }\end{array}$ & 8 & 3,7 \\
\hline $\begin{array}{l}\text { Перерив нижньої порожнистої вени } \\
\text { з її продовженням у напівнепарну вену }\end{array}$ & 6 & 2,8 \\
\hline $\begin{array}{l}\text { Тотальний аномальний дренаж } \\
\text { легеневих вен }\end{array}$ & 5 & 2,3 \\
\hline Декстракардія & 5 & 2,3 \\
\hline Стеноз (атрезія) аортального клапана & 3 & 1,4 \\
\hline Інверсія шлуночків & 3 & 1,4 \\
\hline $\begin{array}{l}\text { Частковий аномальний } \\
\text { дренаж легеневих вен }\end{array}$ & 2 & 0,9 \\
\hline Судинне кільце & 2 & 0,9 \\
\hline
\end{tabular}


Таблиия 4

Позасерцеві аномалії, асоційовані з АВК $(n=80)$

\begin{tabular}{|c|c|c|c|}
\hline & Аномалія & Абс. & $\%$ \\
\hline $\begin{array}{l}\text { Центральн } \\
\text { а нервова } \\
\text { система }\end{array}$ & $\begin{array}{l}\text { Аномалії розвитку задньої } \\
\text { черепної ямки: } \\
\text { - мальформація Денді-Уокера } \\
\text { - гіпоплазія мозочка } \\
\text { - арахноїдальна кіста } \\
\text { - кіста Карамана-Блейка } \\
\\
\text { Вентрикуломегалія } \\
\text { Агенезія мозолистого тіла } \\
\text { Кісти хориоїдного сплетення } \\
\text { Загальна кількість }\end{array}$ & $\begin{array}{l}3 \\
3 \\
5 \\
1\end{array}$ & $\begin{array}{l}1,4 \\
1,4 \\
2,3 \\
0,46 \\
\\
0,9 \\
0,9 \\
1,8\end{array}$ \\
\hline $\begin{array}{l}\text { Кишково- } \\
\text { шлунковий } \\
\text { тракт }\end{array}$ & $\begin{array}{l}\text { Атрезія стравоходу } \\
\text { Дуоденальна атрезія } \\
\text { Атрезія ануса } \\
\text { Діафрагмальна кила } \\
\text { Загальна кількість }\end{array}$ & $\begin{array}{l}1 \\
4 \\
1 \\
1 \\
7\end{array}$ & $\begin{array}{c}0,46 \\
1,9 \\
0,46 \\
0,46 \\
3,2\end{array}$ \\
\hline $\begin{array}{l}\text { Аномалії } \\
\text { кінцівок }\end{array}$ & $\begin{array}{l}\text { Клинодактилія } \\
\text { Варусна деформація стопи } \\
\text { Коротка плечова кістка } \\
\text { Загальна кількість }\end{array}$ & $\begin{array}{l}3 \\
4 \\
1\end{array}$ & \begin{tabular}{|l|}
1,4 \\
1,9 \\
0,5
\end{tabular} \\
\hline $\begin{array}{l}\text { Лицеві } \\
\text { аномалії }\end{array}$ & $\begin{array}{l}\text { Мікрофтальмія } \\
\text { Плоский профріль обличчя } \\
\text { Зменшені розміри носової кістки } \\
\text { Розщеплення твердого } \\
\text { піднебіння } \\
\text { Загальна кількість }\end{array}$ & $\begin{array}{c}3 \\
14 \\
23\end{array}$ & $\begin{array}{l}1,4 \\
6,5 \\
10,7\end{array}$ \\
\hline $\begin{array}{l}\text { Ниркова } \\
\text { система }\end{array}$ & $\begin{array}{l}\text { Двосторонній гідронефроз нирок } \\
\text { Білатеральна мультицистозна } \\
\text { дисплазія нирок } \\
\text { Загальна кількість }\end{array}$ & 8 & 3,7 \\
\hline $\begin{array}{l}\text { Інші } \\
\text { аномалії }\end{array}$ & $\begin{array}{l}\text { Водянка плода } \\
\text { Єдина артерія пуповини } \\
\text { Маловоддя } \\
\text { Багатоводдя } \\
\text { Множинні гіперехогенні фрокуси } \\
\text { Аномальне розташування } \\
\text { венозної протоки } \\
\text { Кістозно-аденоматозна вада } \\
\text { розвитку нижньої частки лівої } \\
\text { легені } \\
\text { Загальна кількість }\end{array}$ & $\begin{array}{c}7 \\
12 \\
3 \\
14 \\
22 \\
7 \\
1\end{array}$ & $\begin{array}{c}3,3 \\
5,6 \\
1,4 \\
6,5 \\
10,2 \\
3,3 \\
0,46\end{array}$ \\
\hline
\end{tabular}

розвитку або хромосомна патологія мають несприятливий віддалений прогноз. Жінки, які вирішили продовжити вагітність, обстежувались повторно у терміні 32 тижні гестації для вирішення перинатальної тактики. У випадках виявлення ознак серцевої недостатності у плода, водянки плода, а також при порушеннях ритму серця плода обстеження вагітних проводили частіше.

Дітей з ізольованою АВК обстежували після народження у віці одного місяця. При поєднанні АВК з протокозалежним легеневим або системним кровотоком обстеження новонароджених проводили в перші години або дні життя.

Дослідження виконані відповідно до принципів Гельсінської Декларації. Протокол дослі- дження ухвалений Локальним етичним комітетом (ЛЕК) всіх зазначених у роботі установ. На проведення досліджень було отримано проінформовану згоду батьків дітей.

У процесі дослідження аналізували випадки асоційованих серцевих та позасерцевих вад розвитку, їх зв'язок із хромосомною патологією i визначали їх вплив на пренатальний та антенатальний період.

Для статистичного аналізу використовувалась програма SPSS Statistics. Порівняння частот якісних показників у групах проводили шляхом побудови таблиць сполученості 2x2 із застосуванням критерію хі-квадрат або точного методу Фішера. Рівень достовірності р був двобічним, критерієм статистичної достовірності був $\mathrm{p}<0,05$, що вважався статистично значущим.

\section{Результати дослідження та їх обговорення}

Атріовентрикулярна комунікація діагностована у 215 плодів. Переважна більшість вагітностей була одноплідною. У трьох випадках вагітність була двома плодами. Із 215 плодів живими народилися 120 (55,8\%) дітей. Інформацію про переривання вагітності, випадки внутрішньоутробної загибелі плода та випадки неонатальної смерті отримано під час опитування жінок по телефону. В усіх інших випадках діагноз підтверджено під час постнатального обстеження. Демографічні дані наведені у табл. 1. Каріотип плода на момент первинної консультації був відомий у 45 $(20,9 \%)$ випадках. Хромосомні аномалії були у 30 (14\%) плодів: у 27 (12,6\%) випадках була виявлена трисомія 21 , в $1(0,46 \%)$ - трисомія 13, в $1(0,46 \%)$ - трисомія 18, в 1 (0,46\%) плода був діагностований синдром Ді-Джорджі.

Основні показання до проведення фетальної Ехо-КГ наведені у табл. 2. Аномальний 4-камерний зріз був найчастішою причиною скерування (98, або 46,2\% плодів) на проведення фетальної ехокардіографії. Атріовентрикулярна комунікація як ізольована вада серця була діагностована у 111 (51,6\%) випадках.

Супутні внутрішньосерцеві аномалії було виявлено у 104 (48,3\%) випадках. Детальну інформацію по кожній супутній аномалії наведено у табл. 3. Одна додаткова внутрішньосерцева вада розвитку була діагностована у 15 (7\%) плодів, дві додаткові аномалії у $10(4,7 \%)$ випадках. У 78 (36,3\%) випадках виявлено більше двох внутрішньосерцевих вад розвитку, тому загальна кількість супутньої 
Випадки внутрішньоутробної загибелі плода $(\mathrm{n}=8)$

Таблиия 5

\begin{tabular}{|c|c|c|c|c|c|}
\hline $\begin{array}{c}\text { № } \\
\mathbf{3} / \mathbf{n}\end{array}$ & $\begin{array}{c}\text { Гестаційний } \\
\text { вік на момент } \\
\text { внутрішньоутробної } \\
\text { загибелі (тижні) }\end{array}$ & $\begin{array}{c}\text { Тип } \\
\text { АВК }\end{array}$ & $\begin{array}{c}\text { додаткові } \\
\text { серцеві } \\
\text { аномалії }\end{array}$ & $\begin{array}{c}\text { додаткові } \\
\text { позасерцеві } \\
\text { аномалії }\end{array}$ & каріотип \\
\hline 1 & 38 & Комбінована & $\begin{array}{c}\text { Виразна недостатність спільного АВ-клапана } \\
\text { та с-м гетеротаксії (правий ізомеризм) }\end{array}$ & $\begin{array}{c}\text { Дуоденальна } \\
\text { атрезія }\end{array}$ & Нормальний \\
\hline 2 & 32 & Комбінована & $\begin{array}{c}\text { Виразна недостатність спільного АВ-клапана } \\
\text { та с-м гетеротаксії (лівий ізомеризм) }\end{array}$ & Відсутні & Нормальний \\
\hline 3 & 37 & Ізольована & Виразна недостатність спільного АВ-клапана & Водянка плода & Трисомія 21 \\
\hline 4 & 34 & Ізольована & Виразна недостатність спільного АВ-клапана & $\begin{array}{c}\text { Атрезія } \\
\text { стравоходу та } \\
\text { водянка плода }\end{array}$ & Трисомія 21 \\
\hline 5 & 27 & Комбінована & АВ-блокада та лівий ізомеризм & Відсутні & Нормальний \\
\hline 6 & 31 & Комбінована & Виразна недостатність спільного АВ-клапана & Водянка плода & Трисомія 21 \\
\hline 7 & 35 & Ізольована & Виразна недостатність спільного АВ-клапана & Відсутні & Нормальний \\
\hline 8 & 38 & Ізольована & Виразна недостатність спільного АВ-клапана & Відсутні & Нормальний \\
\hline
\end{tabular}

внутрішньосерцевої патології значно перевищує кількість випадків. Із 29 плодів, у яких пренатально діагностовано синдром гетеротаксії, 23 (10,7\%) мали правопередсердний ізомеризм i $6(2,8 \%)$ - лівопередсердний.

У 80 (37,2\%) плодів АВК поєднувалась з позасерцевими вадами розвитку. Спектр аномалій включав патологію центральної нервової системи, кишково-шлункового тракту, кінцівок, обличчя та інших органів і систем (табл. 4).

У 32 (14,9\%) плодів спостерігали комплекс аномалій розвитку в декількох системах органів, тому їх загальна кількість також значно перевищує кількість випадків.

У 87 (40,5\%) з 215 випадків вагітність була перервана. У 120 (55,8\%) випадках вагітність закінчилась пологами. У 8 (3,7\%) випадках вагітність закінчилась внутрішньоутробною загибеллю плода, з них у 4 була діагностована комбінована АВК, в інших 4 - ізольована АВК, що підтверджено результатами патологоанатомічного дослідження (табл. 5).
Аналіз груп плодів з ізольованою та комбінованою АВК не виявив статистично достовірної різниці у частоті переривання вагітності за наявності ізольованої патології серця $(43,2 \%)$ порівняно з тими, хто мав більш складну анатомію $(35,6 \%)$. Проте хромосомні аномалії та супутня позасерцева патологія частіше зустрічались у групі ізольованої АВК (табл. 6).

Із 120 народжених живими 63 (28,8\%) малюки померли протягом перших місяців життя, не отримавши кардіохірургічної допомоги. Причиною смерті у більшості випадків було поєднання вади серця 3 позасерцевою та/або хромосомною патологією, що призвело до виникнення поліорганної недостатності, як на етапі адаптації дитини у ранньому неонатальному періоді, так і на етапі лікування супутньої патології.

Лише 57 (26,5\%) пацієнтам проведено хірургічне лікування. Загальна виживаність протягом трирічного періоду спостереження склала для пацієнтів 3 ізольованою

Порівняльна характеристика плодів з ізольованою та комбінованою АВК (n=215)

Таблиия 6

\begin{tabular}{|l|c|c|c|}
\hline \multicolumn{1}{|c|}{ Параметри } & Ізольована АВK (n=111) & Комбінована ABK (n=104) & P \\
\hline Середній вік (роки) & $30,6 \pm 7,0$ & $30,5 \pm 5,9$ & 0,859 \\
\hline Середній термін гестації (тижні) & $24,1 \pm 5,5$ & $25,1 \pm 5,9$ & 0,208 \\
\hline Екстракардіальні аномалії (\%) & $49(44,1 \%)$ & $31(29,8 \%)$ & $0,030^{*}$ \\
\hline Хромосомні аномалії (\%) & $24(21,6 \%)$ & $6(5,7 \%)$ & $0,001^{*}$ \\
\hline Переривання вагітності (\%) & $48(43,2 \%)$ & $39(37,5 \%)$ & 0,251 \\
\hline Внутрішньоутробна загибель плода (\%) & $4(3,6 \%)$ & $4(3,8 \%)$ & 0,945 \\
\hline Народжені живими (\%) & $59(53,1 \%)$ & $61(58,7 \%)$ & 0,945 \\
\hline $\begin{array}{l}\text { Хромосомні аномалії, діагностовані } \\
\text { після народження (\%) }\end{array}$ & $49(44,1 \%)$ & $17(16,3 \%)$ & $0,001^{*}$ \\
\hline Отримали кардіохірургічну допомогу (\%) & $37(33,3 \%)$ & $20(19,2 \%)$ & $0,001^{*}$ \\
\hline $\begin{array}{l}\text { Загальна виживаність протягом трирічного } \\
\text { періоду спостереження (\%) }\end{array}$ & $31(27,9 \%)$ & $16(15,4 \%)$ & 0,237 \\
\hline
\end{tabular}

Примітка: * - різниця статистично значуща. 
АВК 27,9\%, для пацієнтів 3 комбінованою АВК - 15,4\%. Середній вік виживання склав 28,4 $\pm 5,3$ місяці.

Із 215 плодів з пренатально діагностованою АВК хромосомна патологія виявлена у 66 (30,7\%) новонароджених, 63 (29,3\%) 3 яких мали синдром Дауна.

Прогноз для плода з АВК залежить від супутньої патології, як серцевої, так і позасерцевої, при незмінній частоті припинення вагітності та смерті новонароджених [1,2].

У нашому спостереженні 87 (40,5\%) сімей вирішили перервати вагітність: у 23\% випадках АВК була ізольованою і у 18\% поєднувалася 3 іншими внутрішньосерцевими вадами розвитку. Із 128 пролонгованих вагітностей 120 закінчились народженням дитини. Коли ми виключаємо переривання вагітності, виживання для плодів 3 ізольованою та комбінованою АВК становить 53,1\% та 58,7\% відповідно.

\section{Висновки}

У нашому дослідженні хромосомна патологія, асоційована 3 АВК, діагностована у 66 (30,7\%) новонароджених, 63 (29,3\%) з яких мали синдром Дауна, що є статистично достовірним ( $\mathrm{p}=0,001)$. Інші серцеві вади розвитку та позасерцева патологія виявлені у 48,3\% та $37,2 \%$ випадків відповідно. Встановлено, що хромосомні аномалії та супутня позасерцева патологія частіше зустрічались у групі 3 ізольованою АВК. Виживаність для плодів з ізольованою та комбінованою АВК становить $53,1 \%$ та 58,7\%. Із 120 народжених живими $28,8 \%$ немовлят померли протягом перших місяців життя. Достовірно встановлено, що кардіохірургічне лікування проведено лише 26,5\% пацієнтам ( $\mathrm{p}=0,001)$. Загальна виживаність протягом трирічного періоду спостереження склала для пацієнтів з ізольованою АВК 27,9\%, для пацієнтів з комбінованою АВК - 15,4\%.

Розуміння впливу екстракардіальних та хромосомних аномалій на фізіологію плода з АВК, знання ризику додаткових серцевих вад для якості життя дитини після народження та володіння можливим потенціалом іх усунення значно підвищує ефективність пренатальної діагностики у визначенні прогнозу для плода з АВК.

Автори заявляють про відсутність конфлікту інтересів.

\section{ЛITEPАТУРА}

1. Allan LD, Sharland GK, Chita SK, Lockhart S, Maxwell DJ. (1991). Chromosomal anomalies in fetal congenital heart disease. Ultrasound in Obstetrics and Gynecology. 1;1:8-11.

2. Beaton AZ, Pike JI, Stallings C, Donofrio MT. (2013, Feb.). Predictors of repair and outcome in prenatally diagnosed atrioventricular septal defects. J Am Soc Echocardiogr.26(2):208-16.

3. Calkoen EE, Hazekamp MG, Blom NA et al.(2016,Jan). Atrioventricular septal defect: From embryonic develop-

ment to long-term follow-up. Int $\mathrm{J}$ Cardiol.
$1 ; 202: 784-95$
1;202:784-95.

4. Craig B. (2006). Atrioventricular septal defect: from fetus to adult. Heart. 92;12:1879-1885.

5. Huggon IC, Cook AC, Smeeton NC, Magee AG, Sharland GK. (2000). Atrioventricular septal defects diagnosed in fetal life: associated cardiac and extra-cardiac abnormalities and outcome. Journal of the American College of Cardiology. 36;2:593-601.

\section{Сведения об авторах:}

Шаповал Людмила Анатольевна - врач-кардиолог детский ГУ «Научно-практический медицинский центр детской кардиологии и кардиохирургии МЗ Украины».

Адрес: г. Киев, ул. Черновола, 28/1.

Куркевич Андрей Казимирович - к.мед.н., зав. отделения ГУ «Научно-практический медицинский центр детской кардиологии и кардиохирургии МЗ Украины».

Адрес: г. Киев, ул. Черновола, 28/1.

Статья поступила в редакцию 12.11.2018 г.; принята в печать 13.03.2019 г.

\section{ВНИМАНИЕ!}

Подписку журнала (с курьерской доставкой) можно оформить на сайте подписного агентства «АC-Медиа» web: www.smartpress.com.ua/ или по тел. 044-353-88-16, 044-500-05-06 - отдел продаж.

Подписной индекс журнала «СОВРЕМЕННАЯ ПЕДИАТРИЯ» - $\mathbf{0 9 8 5 0}$ 


\title{
Ефективність поєднаного використання сальбутамолу та екстракту плюща в амбулаторному лікуванні гострих респіраторних захворювань з бронхообструкцією
}

\author{
ДВНЗ «Тернопільський державний медичний університет імені І.Я. Горбачевського МОЗ України» \\ SOVREMENNAYA PEDIATRIYA.2019.2(98):18-22; doi 10.15574/SP.2019.98.18
}

\begin{abstract}
Мета - дослідити ефрективність поєднаного застосування сальбутамолу та екстракту плюща для лікування кашлю при гострому бронхіті (ГБ) на тлі гострого респіраторного захворювання (ГРЗ) з елементами бронхообструкції.

Матеріали і методи. Об'єктом дослідження були 26 пацієнтів із ГБ на тлі ГР3 з бронхообструктивним синдромом. Група I (14 хворих) отримувала комплекс загальноприйнятого лікування протягом 7-10 днів. Він включав антибактеріальні препарати та симптоматичні засоби за необхідності, протизапальні нестероїдні засоби, антигістамінний препарат, вітамін С. Група II (12 хворих) отримувала аналогічний комплекс загальноприйнятого лікування із поєднанням сальбутамолу та екстракту плюща протягом 7-10 днів.

Результати. У хворих II групи спостерігалася виразніша позитивна динаміка за елімінацією проаналізованих симптомів, ніж у хворих I групи: сумарно з 91,7\% до 10,7\% та з 91,4\% до 30,0\% пацієнтів відповідно. Після лікування відбулося достовірне зниження рівнів лейкоцитів (у т.ч. паличкоядерних і сегментоядерних) у перифреричній крові, СРП, фібриногену, ШОЕ крові ( $<0,05)$ в обох групах. Однак ефрективність лікування у II групі була достовірно вищою, ніж у I групі, за всіма показниками $(p<0,05)$. У II групі порівняно 3 I групою достовірно знизилися показники гуморального імунітету: IgG — на 6,45\%, IgA — на 19,64\%, IgM — на 14,75\%, ЦІІ — на $25,63 \%$.

Висновки. Клінічно доведено, що поєднане використання бронхолітика сальбутамолу і фітозасобу з екстракту плюща у комплексному лікуванні хворих на ГРЗ з ГБ і бронхообструкцією є доцільним у зв'язку з вищою ефективністю даної терапевтичної програми за загальноприйняту.

Ключові слова: гостре респіраторне захворювання, гострий бронхіт, бронхообструкція, сальбутамол, екстракт плюща.
\end{abstract}

\section{Effectiveness of co-use of salbutamol and extrakt hederis folia in ambulatory treatment of acute respiratory diseases with bronchoobstruction} L.S. Babinets

Ternopil State Medical University by I.Ya. Gorbachevsky of Ministry of Health of Ukraine

The article presents the results of the study, which proved that the co-use of bronchodilatator Salbutamol and extract from the Hederis Folia, according to the proposed methodology by the authors, in the complex treatment of patients with acute respiratory disease (ARI) with acute bronchitis (AB) and bronchoobstruction is appropriate for optimization of clinical parameters, inflammation markers, parameters of humoral level immunity and complement system in connection with the higher effectiveness of this treatment program as a general.

The purpose of the study is to investigate the combined use of salbutamol and Hederis Folia extract extract for the treatment of cough with acute bronchitis in the context of acute respiratory disease with elements of bronchoconstriction.

Materials and methods. The subject of the study was 26 patients with AB in the background of ARI with broncho-obstructive syndrome. Patients with ARI and AB were divided into groups of comparison: Group I (14 patients) received a complex of GT for 7-10 days. It included antibacterial drugs (most often amoxicillin, protected aminopenicillin or macrolide in therapeutic doses), and symptomatic drugs, if necessary, nonsteroid anti-inflammatory agents (more often ibuprofen), antihistamines (most often fenspirids), vitamin C. Group II (12 patients) received a similar complex GT with a combination of salbutamol and Hederis Folia extract in the above doses for 7-10 days.

Results and conclusuons. Patients of the second group had a more pronounced positive dynamics after the elimination of the analyzed symptoms than in patients with Group I: in total from $91.7 \%$ to $10.7 \%$ and $91.4 \%$ and $30.0 \%$ of patients, respectively. This has shown a significantly higher efficiency of combined use of salbutamol and Hederis Folia extract in the complex treatment of patients with ARI. After treatment there was a significant decrease in the levels of leukocytes in peripheral blood, CRP, fibrinogen, ESR $(p<0,05)$ in both groups. However, the efficacy of treatment in group II was significantly higher than in group I (in all indicators $p<0.05$ ), which proved the expediency of combined use of salbutamol and Hederis Folia extract in combination therapy of ARI with $A B$ and bronchoconstriction for correction of inflammatory syndrome. Significantly, the indicators of humoral immunity in the II group decreased compared with the I group: IgG — by $6.45 \%$, IgA — by $19.64 \%$, IgM — by $14.75 \%$, CIC — by $25.63 \%$, which showed a higher efficiency. combined use of salbutamol and Hederis Folia extract in the complex treatment of patients with $A R I$ with $A B$ and bronchial obstruction.

Key words: acute respiratory disease, acute bronchitis, bronchoconstriction, salbutamol, Hederis Folia extract.

\section{Эффективность сочетанного использования сальбутамола и экстракта плюща в амбулаторном лечении острого респираторного заболевания с бронхообструкцией \\ Л.С. Бабинец \\ ГВУЗ «Тернопольский государственный медицинский университет имени И.Я. Горбачевского МЗ Украины»}

Цель - исследовать эффективность сочетанного применения сальбутамола и экстракта плюща для лечения кашля при остром бронхите (ОБ) на фоне острого респираторного заболевания (ОРЗ) с элементами бронхообструкции.

Материалы и методы. Объектом исследования были 26 пациентов с ОБ на фроне ОР3 с бронхообструктивным синдромом. Группа I (14 больных) получала комплекс общепринятого лечения в течение 7-10 дней, включавший антибактериальные препараты и симптоматические средства при необходимости, противовоспалительные нестероидные средства, антигистаминный препарат, витамин С. Группа II (12 больных) получала аналогичный комплекс общепринятого лечения и сочетание сальбутамола и экстракта плюща в течение 7-10 дней.

Результаты. У больных II группы наблюдалась более выразительная положительная динамика элиминации анализировавшихся симптомов, чем у больных I группы: суммарно с 91,7\% до 10,7\% и с 91,4\% до 30,0\% пациентов соответственно. После лечения произошло достоверное снижение 
уровней лейкоцитов (в т.ч. палочкоядерных и сегментоядерных) в периферической крови, СРП, фрибриногена, СОЕ крови (р<0,05) в обеих группах. Однако эфрфективность лечения во II группе была достоверно выше, чем во I группе, по всем показателям (p<0,05). Во II группе по сравнению с I группой достоверно снизились показатели гуморального иммунитета: IgG — на 6,45\%, IgA — на 19,64\%, IgM — на 14,75\%, ЦИК — на 25,63\%.

Выводы. Клинически доказано, что сочетанное использование бронхолитика сальбутамола и фитосредства из экстракта плюща в комплексном лечении больных ОРЗ с ОБ и бронхообструкцией является целесообразным в связи с более высокой эффективностью данной терапевтической программы по сравнению с общепринятой.

Ключевые слова: острое респираторное заболевание, острый бронхит, бронхообструкция, сальбутамол, экстракт плюща.

\section{Вступ}

Гострі респіраторні захворювання (ГРЗ) 1 є однією з актуальних проблем амбулаторної практики, адже $50-90 \%$ населення в світі щорічно хворіють на ГРЗ (або так звані «застудні захворювання» - «common cold»). Кількість звернень по медичну допомогу, які пов'язані 3 «common cold», у США становить приблизно 25,0 млн випадків на рік, в Україні - 4,0-4,5 млн [5]. Основними принципами терапії ГРЗ є режим, обов'язкове введення додаткової рідини (об'єм у 1,5-2 рази більший за добові потреби), противірусна терапія, застосування топічних антибіотиків і симптоматичних засобів (жарознижувальні, анестетики, антисептики, судинозвужувальні краплі тощо), а у випадку бактерійних ускладнень системних антибіотиків [3]. У веденні хворих на ГРЗ важливо виконувати три режимні завдання: 1) оптимізація фізичних параметрів повітря - чисте, прохолодне, зволожене повітря у приміщенні, де перебуває хворий, є обов'язковою умовою сприятливого перебігу (оптимальна температура у приміщенні $17-19{ }^{\circ} \mathrm{C}$, вологість $\left.-75-90 \%\right)$; 2) режим харчування - абсолютно неприпустиме примусове годування; зменшення об'єму одного годування за рахунок збільшення кратності прийому їжі, легкозасвоювані вуглеводи; 3) регідратація - збільшення добового об'єму рідини у 1,5-2 рази, температура рідини кімнатна; критерії ефективної регідратації - вологість слизових оболонок і шкіри, ефективний діурез, нормалізація температури тіла і частоти серцевих скорочень [1].

Одним із проявів ГРЗ є гострий бронхіт (ГБ), діагноз якого найчастіше асоціюється 3 неадекватним застосуванням антибіотиків. За даними досліджень, 53-83\% хворих на ГБ приймають антибіотики. За сучасними уявленнями про етіотропну терапію, більшість хворих на ГРЗ і ГБ не потребують призначення антибіотикотерапії; у 50-80\% хворих на ГБ спостерігається необгрунтоване застосування антибіотиків; необхідно мінімізувати використання антибіотиків при ГБ вірусної етіології та призначати противірусні препарати [5].
Понад 90\% батьків хворих дітей і дорослі пацієнти очікують призначення антибіотиків, тому лікарі часто змушені перестраховуватись, боячись за життя дитини, тиску з боку батьків та юридичної відповідальності. Найчастішими «показаннями» до помилкового призначення антибіотиків є лихоманка, кашель, «профілактичний прийом», лікування ex juvantibus і просто ГРЗ [2].

За результатами 17 рандомізованих контрольованих досліджень із загальною кількістю 3936 пацієнтів встановлено, що на тлі застосування антибіотиків середнім курсом 7 днів період зі скаргами на кашель був лише на 12 год меншим, період, коли пацієнт відчуває себе хворим, - лише на 8 год меншим, а період обмеження активності - лише на 12 год меншим, ніж у групі пацієнтів, які не отримували лікування антибіотиками. Було зроблено висновок, що застосування антибіотиків у більшості випадків не рекомендується, проте відсутність клінічного покращання протягом тижня у дітей дошкільного віку або важкий загальний стан, частий продуктивний кашель протягом дня у дорослих пацієнтів, а також похилий та старечий вік можуть виправдати іх використання. Також констатували відсутність доказів щодо переваг будь-якого з режимів застосування антибіотиків. Залишаються не з'ясованим положення, що у лікуванні хворих на ГБ не варто використовувати антибіотики широкого спектра дії [6].

На сьогодні розроблено чіткі показання до призначення антибіотиків при ГБ: 1) ГБ мікоплазменної і хламідійної етіології; 2) діти перших шести місяців життя; 3) важкий перебіг ГБ із виразними симптомами інтоксикації (нейротоксикоз тощо); 4) гіпертермія $\left(>39^{\circ} \mathrm{C}\right)$ більше 3-5 днів від початку захворювання або повторна гіпертермія після періоду нормальної температури тіла; 5) наявність ускладненого преморбідного фону (травма у пологах, недоношеність, гіпотрофія тощо); 6) наявність активних вогнищ хронічної інфекції (тонзиліт, отит тощо); 7) затяжний перебіг захворювання; 8) наявність обструктивного синдрому і клінічної картини бронхіоліту і пневмонії; 9) лейко- 
цитоз, збільшена ШОЕ, наявність СРБ ( $\geq 50$ мг/л); 10) наявність імунодефіцитного стану $[1,6]$.

Не показані до застосування при ГРЗ з рівнем доказовості В антибіотики, сальбутамол у дітей без бронхообструкції, відхаркувальні засоби; з рівнем доказовості С - протикашльові засоби у дітей молодше 6 років. Показані 3 рівнем доказовості В епізодичні інгаляції високих доз глюкокортикостероїдів, сальбутамол у дітей з бронхообструкцією (інгаляційний шлях введення значно ефективніший за пероральний), гречаний мед, екстракт кореня пеларгонії, із рівнем доказовості D - ехінацея [1,4].

Виходячи 3 вищенаведеного, було запропоновано поєднане використання бронхолітика сальбутамолу та екстракту плюща. Сальбутамол є протиастматичним засобом для інгаляційного або перорального застосування. Він є відносно специфічним агоністом бета-2-адренорецепторів, тому при застосуванні високих доз може стимулювати і бета-1-адренорецептори. Сальбутамол має бронходилатаційний ефект, внаслідок якого купіруються явища бронхоспазму та гальмується дегрануляція опасистих клітин і вивільнення медіаторів запалення (лейкотриєнів, гістаміну), які провокують явища брохоспазму. Бронходилатаційний ефект досягається шляхом стимуляції бета-2-адренорецепторів і внутрішньоклітинною акумуляцією циклічного 3'5'-аденозинмонофосфату. Механізм впливу сальбутамолу на секрецію слизу у бронхах залишається не з'ясованим. Бронходилатаційний ефект починається через 5 хвилин після застосування, від $10 \%$ до 20\% введеної дози досягає нижніх дихальних шляхів, і триває 4-6 годин. Класичними показаннями до застосування сальбутамолу є зняття нападів задухи при бронхіальній астмі та профілактика очікуваних нападів бронхоспазму. У нашому випадку вони можуть виникати як прояв ГБ на тлі ГРЗ. Для купірування гострого бронхоспазму дорослим і дітям від 12 років застосовують сальбутамол у дозі 100-200 мкг (1-2 інгаляції), дітям від 4 до 12 років - 1 інгаляцію (100 мкг). При правильному застосуванні препарат не викликає побічних явищ, але може викликати легкий м'язовий тремор, особливо рук, інколи може виникати головний біль, незначна компенсаторна тахікардія, рідше - симптоми гіперчутливості (ангіоневротичний набряк, кропив'янка, бронхоспазм, гіпотонія з непритомністю). При довготривалому лікуванні сальбутамолом повідомлялось про випадки тахікардії та інших порушень серцевого ритму, включаючи фібриляцію шлуночків, суправентрикулярну тахікардію та екстрасистолію. Але це не притаманно короткочасному коректному застосуванню при ГБ з бронхоспазмом на тлі ГРЗ. У пероральній формі дорослі і діти від 6 років приймають по 2 мг сальбутамолу 3 рази на день, за необхідності - по 4 мг 3-4 рази на день; діти від 2 до 6 років - 2,5 мл сиропу (1 мг) 3 рази на день, за необхідності дозу можна збільшити до 5 мл сиропу (2 мг) 3-4 раза на день.

Сироп плюща є препаратом класичної медицини, відповідає вимогам GMP, виготовляється з якісної рослинної сировини - сухого екстракту листя плюща (Hederis folia), гедеракозиду C 14\% 4,5 мг, що містить декілька класів діючих субстанцій (сапоніни - $\alpha$-гедерин, ефеусапоніни, гедерасапоніни, фітостероли, флавоноїди, ефірні олії тощо), має широкий спектр дії та низький ризик побічних ефектів. Механізм дії вивчений на молекулярному і клітинному рівнях: $\alpha$-гедерин збільшує бета-2-адренергічну стимуляцію, посилює продукцію сурфактанту, знижуючи в'язкість слизу, а також розслабляє м'язи бронхів, забезпечуючи бронходилатацію. Препарат є муколітиком і мукокінетиком, має бронхолітичний ефект, чинить протизапальну і м'яку протикашльову дію. Хворим призначають по 5,0-7,5 мл сиропу 3 рази на добу за допомогою дозуючого пристрою, що додається [3]. Доцільність додавання екстракту плюща у лікування кашлю зумовлена тим, що біологічно активні речовини фітопрепарату більш природно включаються у процеси, які відбуваються в організмі людини, а їх ефективність пов'язана з великою кількості біологічно активних речовин. Фітопрепарати мають добру переносимість, небажані медикаментозні реакції розвиваються рідко, а пацієнти загалом прихильні до таких засобів.

У медичній літературі є багато повідомлень щодо цих лікарських засобів, однак щодо поєднаного їх використання інформації недостатньо, що й слугувало мотивацією до проведення даного дослідження.

Mema дослідження - дослідити ефективність поєднаного застосування сальбутамолу та екстракту плюща для лікування кашлю при гострому бронхіті на тлі ГРЗ з елементами бронхообструкції.

\section{Матеріал і методи дослідження}

Об'єктом дослідження були 26 пацієнтів (14 жінок і 12 чоловіків) із ГБ на тлі ГРЗ 3 
Динаміка клінічних проявів у хворих на ГРЗ з ГБ та бронхообструкцією

Таблиия 1 під впливом різних лікувальних комплексів

\begin{tabular}{|l|c|c|c|c|}
\hline \multirow{2}{*}{ Клінічний прояв } & \multicolumn{3}{|c|}{ Група порівняння } \\
\cline { 2 - 5 } & \multicolumn{2}{|c|}{ І група (n=14) } & \multicolumn{2}{c|}{ II група (n=12) } \\
\cline { 2 - 5 } & до лікування, абс. (\%) & після лікування, абс. (\%) & до лікування, абс. (\%) & після лікування, абс. (\%) \\
\hline Гіпертермія & $12(85,7)$ & $5(35,7)^{*}$ & $11(91,7)$ & $2(16,7)$ \\
\hline Кашель & $14(100,0)$ & $3(21,4)$ & $12(100,0)$ & $1(8,3)$ \\
\hline Нежить & $14(100,0)$ & $3(21,4)$ & $12(100,0)$ & $0(0)$ \\
\hline Головний біль & $12(85,7)$ & $5(35,7)$ & $12(100,0)$ & $0(0)$ \\
\hline Задишка & $11(78,6)$ & $4(28,6)$ & $11(91,7)$ & $2(25,0)$ \\
\hline Астенічний синдром & $14(100,0)$ & $4(28,6)$ & $10(83,3)$ & $1(8,3)$ \\
\hline Пітливість & $13(92,9)$ & $5(35,7)$ & $11(91,7)$ & 10,7 \\
\hline Сумарний показник, \% & 91,4 & 30,0 & 91,7 & \\
\hline
\end{tabular}

Примітка: * - відсутність значущої позитивної динаміки.

бронхообструктивним синдромом, які лікувались у поліклінічному відділенні Тернопільської міської лікарні №2 і Тернопільського Центру ПМСД. Вік хворих становив від 17 до 54 років. Верифікацію діагнозу ГРЗ з ГБ і бронхообструкцією та розробку комплексу загальноприйнятого лікування (ЗЛ) проводили за стандартними вимогами, затвердженими MO3 України [1-3]. Ступінь запалення та інтоксикації визначали за рівнем лейкоцитозу, паличкоядерних і сегментоядерних нейтрофілів, С-реактивного протеїну (СРП), фібриногену крові, швидкості осідання еритроцитів (ШОЕ), застосовуючи загальноприйняті лабораторні методики. Функціональна активність В-лімфоцитів оцінювалась за концентрацією сироваткових Ig основних класів (M, G, A). Визначення Ig у сироватці крові проводилося методом радіальної імунодифузії глобулінів за G. Mancini та співавт. За допомогою гемолітичного тесту ( $\mathrm{C}_{\text {н50 }}$ за $50,0 \%$ гемолізом) визначали активність системи комплементу. Рівень циркулюючих імунних комплексів (ЦІК) визначали методом селективної преципітації у 3,75\% етиленгліколі з наступним фотометруванням.

Пацієнтів із ГРЗ і ГБ поділили на групи порівняння: I група (14 хворих) отримувала комплекс ЗЛ протягом 7-10 днів. Він включав антибактеріальні препарати (найчастіше амоксицилін, захищений амінопеніцилін або макролід у терапевтичних дозах) та симптоматичні засоби за необхідності, протизапальні засоби нестероїдної дії (частіше ібупрофен), антигістамінний препарат (частіше фенспірид), вітамін С.

Група II (12 хворих) для лікування кашлю 3 елементами бронхообструкції отримувала аналогічний комплекс ЗЛ із поєднанням сальбутамолу та екстракту плюща протягом 7-10 днів.

Групу контролю склали 20 молодих здорових людей для порівняння лабораторних параметрів.

Дослідження виконані відповідно до принципів Гельсінської Декларації. Протокол дослідження ухвалений Локальним етичним комітетом установ. На проведення досліджень було отримано поінформовану згоду пацієнтів або їхніх батьків.

\section{Результати дослідження та їх обговорення}

Динаміка клінічних проявів захворювання (задишка, кашель, нежить, головний біль, підвищення температури тіла, пітливість, слабкість) на тлі лікування показана у табл. 1. У хворих II групи спостерігалася виразніша позитивна динаміка за елімінацією проаналізованих симптомів, ніж у хворих I групи: сумарно

Динаміка маркерів запалення у хворих на ГРЗ з ГБ та бронхообструкцією

Таблиия 2 під впливом різних лікувальних комплексів

\begin{tabular}{|c|c|c|c|c|c|}
\hline \multirow{3}{*}{ Показник } & \multicolumn{5}{|c|}{ Група порівняння } \\
\hline & \multirow{2}{*}{$\begin{array}{c}\text { Контроль } \\
(\mathrm{n}=20)\end{array}$} & \multicolumn{2}{|c|}{ I група (n=14) } & \multicolumn{2}{|c|}{ II група (n=12) } \\
\hline & & до лікування & після лікування & до лікування & після лікування \\
\hline Лейкоцити, х 10\%/л & $4,91 \pm 0,29$ & $11,26 \pm 0,18$ & $6,52 \pm 0,17^{*}$ & $10,99 \pm 0,18$ & $5,88 \pm 0,16^{* *}$ \\
\hline Паличкоядерні, \% & $2,48 \pm 0,87$ & $7,45 \pm 0,49$ & $4,39 \pm 0,43^{*}$ & $7,67 \pm 0,51$ & $3,41 \pm 0,32^{\star *}$ \\
\hline Сегментоядерні, \% & $49,15 \pm 2,85$ & $69,03 \pm 1,18$ & $57,70 \pm 2,35^{*}$ & $68,13 \pm 1,09$ & $51,40 \pm 1,37^{\star *}$ \\
\hline СРП, кількість (+) & $0,210,09$ & $2,060,45$ & $0,760,36^{*}$ & $2,140,21$ & $0,410,18^{\star *}$ \\
\hline Фібриноген, г/л & $2,121,04$ & $6,110,96$ & $4,250,46$ & $6,210,84$ & $3,290,37^{* *}$ \\
\hline ШОЕ, мм/год & $7,92 \pm 0,39$ & $19,26 \pm 0,40$ & $10,52 \pm 0,17^{*}$ & $19,95 \pm 0,15$ & $9,81 \pm 0,26^{* *}$ \\
\hline
\end{tabular}

Примітки: усі показники до лікування достовірні стосовно групи контролю $(\mathrm{p}<0,05)$; - достовірні відмінності щодо показників у своїй групі до лікування ( $<0,05) ; * *$ - достовірні відмінності щодо показників I групи після лікування $(\mathrm{p}<0,05)$. 
Динаміка показників гуморальної ланки імунної системи у хворих

на ГРЗ з ГБ під впливом різних лікувальних комплексів

\begin{tabular}{|c|c|c|c|c|c|}
\hline \multirow[b]{2}{*}{ Показник IC } & \multicolumn{4}{|c|}{ Група хворих на ГРЗ з ГБ } & \multirow[b]{2}{*}{$\mathrm{p}_{4}$} \\
\hline & $\begin{array}{c}\text { до лікування } \\
\text { I група (n=14) }\end{array}$ & $\begin{array}{c}\text { після лікування } \\
\text { I група (n=14) }\end{array}$ & $\begin{array}{c}\text { до лікування } \\
\text { II група (n=12) }\end{array}$ & $\begin{array}{l}\text { після лікування } \\
\text { II група (n=12) }\end{array}$ & \\
\hline $\lg \mathrm{G}$, г/л & $12,31 \pm 0,16$ & $12,25 \pm 0,16 p_{2}>0,05$ & $12,46 \pm 0,17 p_{1}>0,05$ & $11,46 \pm 0,16 p_{3}<0,001$ & $\mathrm{p}_{4}<0,001$ \\
\hline $\lg A, \Gamma / ת$ & $2,99 \pm 0,09$ & $2,80 \pm 0,08 p_{2}<0,01$ & $2,91 \pm 0,08 p_{1}>0,05$ & $2,25 \pm 0,06 p_{3}<0,001$ & $\mathrm{p}_{4}<0,001$ \\
\hline $\lg \mathrm{M}$, г/л & $2,64 \pm 0,07$ & $2,44 \pm 0,06$ p $2<0,001$ & $2,58 \pm 0,07 p_{1}>0,05$ & $2,08 \pm 0,05 p_{3}<0,001$ & $\mathrm{p}_{4}<0,001$ \\
\hline ЦІК, у.о. & $233,54 \pm 6,40$ & $223,62 \pm 6,33 p_{2}<0,001$ & $229,73 \pm 8,10 p_{1}>0,05$ & $166,30 \pm 4,85 p_{3}<0,001$ & $\mathrm{p}_{4}<0,001$ \\
\hline Сн50, гем. од. & $160,14 \pm 2,66$ & $160,32 \pm 2,71 p_{2}>0,05$ & $160,39 \pm 2,47 p_{1}>0,05$ & $185,03 \pm 2,81 p_{3}<0,001$ & $\mathrm{p}_{4}<0,001$ \\
\hline
\end{tabular}

Примітки: р1 - достовірна відмінність даних до лікування у I та II групі; р2 - достовірна відмінність даних до і після лікування у своїй групі; рз - достовірна відмінність даних після лікування у I та II групі; р4 - достовірна відмінність даних стосовно групи контролю.

з 91,7\% до 10,7\% та 91,4\% і 30,0\% пацієнтів відповідно. Це засвідчило достовірно вищу ефективність поєднаного використання сальбутамолу та екстракту плюща у комплексному лікуванні хворих на ГРЗ.

Наступним етапом дослідження був аналіз динаміки досліджуваних маркерів запалення у хворих на ГРЗ з ГБ під впливом різних лікувальних комплексів (табл. 2). На початку лікування зафіксовано достовірне збільшення усіх досліджуваних маркерів запалення. Після лікування відбулося достовірне зниження рівнів лейкоцитів (у т.ч. паличкоядерних і сегментоядерних) у периферичній крові, СРП, фібриногену, ШОЕ крові $(\mathrm{p}<0,05)$ в обох групах. Однак ефективність лікування у II групі була достовірно вищою, ніж у I групі, за всіма показниками $(\mathrm{p}<0,05)$, що засвідчило доцільність поєднаного використання сальбутамолу та екстракту плюща у комплексній терапії ГРЗ з ГБ та бронхообструкцією для корекції запального синдрому.

Дослідження параметрів гуморальної ланки імунної системи показало, що під впливом комплексної терапії у II групі, де застосовували сальбутамол та екстракт плюща, показники достовірно $(p<0,05)$ покращилися, загальна гемолітична активність комплементу - на 15,41\% порівняно з І групою (табл. 3).

Достовірно значущо знизились показники гуморального імунітету у II групі порівняно з I групою: IgG - на 6,45\%, IgA - на 19,64\%, IgM - на 14,75\%, ЦІК - на 25,63\%, що засвідчило вищу ефективність поєднаного використання сальбутамолу та екстракту плюща у комплексному лікуванні хворих на ГРЗ з ГБ та бронхообструкцією.

Таким чином, під впливом поєднання дії бронхолітика сальбутамолу і фітозасобу 3 екстракту плюща не тільки ефективно знімався бронхоспазм, елімінувалися кашель і задишка, але й посилювалися протизапальний, імуномодулюючий і детоксикаційний ефекти загальноприйнятого лікування ГРЗ з ГБ.

\section{Висновки}

Поєднане використання бронхолітика сальбутамолу і фітозасобу з екстракту плюща за запропонованою методикою у комплексному лікуванні хворих на ГРЗ з ГБ і бронхообструкцією є доцільним для оптимізації клінічних показників, маркерів запалення, параметрів гуморальної ланки імунітету і системи комплементу у зв'язку з вищою ефективністю даної лікувальної програми за загальноприйняту.

Перспективи подальших досліджень полягають в обгрунтуванні поєднаного використання бронхолітика сальбутамолу та екстракту плюща у програмі комплексного лікування хворих із патологією дихальної системи з бронхообструктивними станами.

Автори заявляють про відсутність конфлікту інтересів.

\section{ЛITEPATУРА}

1. Возіанова ЖІ. (2008). Інфекційні і паразитарні хвороби: у 3 т. 2-е вид., перероб. і доп. Київ: Здоров'я. Т.1: 884.

2. Голубовська ОА (ред), Андрейчин МА, Шкурба АВ та ін. (2018), Інфекційні хвороби (підручник). 2 видання, доповнене перероблене). Київ: ВСВ Медицина: 688.

3. Мостовий ЮМ. (ред.) (2018). Сучасні класифікації та стандарти лікування розповсюджених захворювань внутрішніх органів. 19-е вид., доп. і перероб. Вінниця: 1180.

4. Anne Meneghetti Upper Respiratory Tract Infection Updated: Jul 31 2015 Medscape. Infectious Diseases Sections. Parasitic Infections. Chief Editor: Zab Mosenifar.

5. Butler CC et al. (2009). Variation in antibiotic prescribing and its impact on recovery in patients with acute cough in primary care: prospective study in 13 countries. BMJ. 338. doi https://doi.org/10.1136/bmj.b2242

6. Smith SM, Fahey T, Smucny J, Becker LA. (2014). Antibiotics for acute bronchitis. Cochrane Database of Systematic Reviews. 3, No.: CD000245.

\section{Сведения об авторах:}

Бабинець Лилия Степановна - д.мед.н., проф., зав, каф. первичной медико-санитарной помощи и общей практики-семейной медицины ГвУз «Тернопольский Гму имени И.Я. Горбачевского МЗ Украины». Адрес: г. Тернополь, Майдан воли, 1 .

Статья поступила в редакцию 30.10.2018 г; принята в печать 02.03.2019 г. 


\title{
Л.И. Сеньковская, В.С. Бирюков, Н.Л. Аряев \\ Ауксологические аспекты дефицита роста у детей Одесской области по данным геоэндемического анализа
}

\begin{abstract}
Одесский национальный медицинский университет, Украина
SOVREMENNAYA PEDIATRIYA.2019.2(98):22-30; doi 10.15574/SP.2019.98.22

Цель: изучение заболеваемости десицит гормона роста (ДГР) у детей, сроков его выявления, территориальной распространенности в различных природных физико-геограсических зонах и биогеохимических провинциях Одесского региона.

Материалы и методы. Изучались данные обследований диспансерной группы детей с ДГР, отраженные в амбулаторных картах эндокринологического центра Одесской областной детской клинической больницы.

Результаты. В 2017 г. на учете эндокринологического центра Одесской областной детской клинической больницы состояло 62 ребенка с нанизмом, обусловленным ДГР. Частота распространенности заболевания составила 1:7 384, а общая заболеваемость ДГР составила 13,54 случая на 100000 детского населения. Из 62 больных ДГР детей мальчиков было 47, а девочек - 15 (соотношение 3,1:1,0). Обнаружена выраженная неоднородность распространенности ДГР в регионе. Наибольшая частота случаев ДГР регистрировалась в Ананьевском - 1:1828, Николаевском - 1:3800, Савранском - 1:3887, Ренийском - 1:4034, Арцизском - 1:4796 и Окнянском - 1:4915 районах. По данным геохимического и геофизического картирования Одесского региона вышеуказанные районы расположены на местности, имеющей неблагоприятные экологические фракторы: гравитационная и магнитная аномалии; точечные аномальные содержания урана, радона, меди, свинца, ртути, стронция, америция на фроне обедненного содержания в почвах цинка, молибдена и кобальта; разломы земной коры; структурно-тектонические и гидрогеологические аномалии.

Выводы. Установлен факт существования ДГР-связанных биогеохимических провинций в Одесском регионе. Продолжение исследований в этом направлении является перспективным и оправданным с точки зрения совершенствования стратегий профилактики и диагностики ДГР.

Ключевые слова: дефицит гормона роста, заболеваемость, географическая распространенность, биогеохимические провинции.
\end{abstract}

Geo-endemic analysis of auxiliary aspects

of growth deficiency in children of Odessa region

L.I. Senkivska, V.S. Biryukov, M.L. Aryayev

Odessa National Medical University, Ukraine

The objective is to study the incidence of growth hormone deficiency (GHD) in children, age of diagnosis and territorial prevalence in various natural physical and geographical zones and biogeochemical provinces in Odessa region.

The study material has been presented by data of examinations the dispensary group of children with GHD, reflected in outpatient cards of endocrinology Center in Odessa Regional Children's Clinical Hospital (ORCCH).

Results. In 201762 children with dwarfism, caused by a growth hormone deficiency (GHD) were supervised in the endocrinology center of ORCCH. The prevalence of disease was 1:7384, and total incidence GHD was 13.54 cases per 100,000 children. 62 children with GHD included 47 boys and 15 girls (ratio 3,1:1). Marked heterogeneity of GHD occurrence in the Odessa Region associated with places of patient's residence has been revealed. The highest occurrence was found in the following districts: Ananievsk - 1:1828, Mykolayiv — 1:3800, Savran - 1:3887, Reni — 1:4034, Artsiz — 1:4796 and Oknyansk — 1:4915. According to the geochemical and geo-physical mapping, the above-mentioned districts are located on areas which are exposed harmful environmental factors: gravitation and magnetic anomalies; point anomalies contents of uranium, radon, copper, plumbum, mercury, strontium, americium against the depleted content in zinc, molybdenum and cobalt soils; the earth's crust and the structural-tectonic and hydrogeological anomalies.

The conclusion. The study established the existence of DGR-related biogeochemical provinces in the Odessa region. The development of such investigations is promising and justified for improving the strategies of prevention and diagnosis DGR.

Key word: Growth hormone deficiency, morbidity, geographical prevalence, biogeochemical provinces.

\section{Ауксологічні аспекти дефіциту росту у дітей Одеської області за даними геоендемічного аналізу \\ Л.І. Сеньківська, В.С. Бірюков, МЛ. Аряєв \\ Одеський національний медичний університет, Україна}

Мета: вивчення захворюваності на дефіцит гормону росту (ДГР) у дітей, термінів його виявлення, територіальної поширеності в різних природних фрізико-географрічних зонах і біогеохімічних провінціях Одеського регіону.

Матеріали і методи. Вивчалися дані обстежень диспансерної групи дітей з ДГР, відображені в амбулаторних картах ендокринологічного центру Одеської обласної дитячої клінічної лікарні.

Результати. У 2017 р. на обліку ендокринологічного центру Одеської обласної дитячої клінічної лікарні перебували 62 дитини 3 нанізмом, обумовленим ДГР. Частота поширеності захворювання склала 1:7384, а загальна захворюваність ДГР - 13,54 випадку на 100000 дитячого населення. Із 62 хворих ДГР дітей хлопчиків було 47, дівчаток - 15 (співвідношення 3,1:1,0). Виявлено виразну неоднорідність поширення ДГР в регіоні. Найбільша частота випадків ДГР реєструвалася в Ананьївському - 1:1828, Миколаївському - 1:3800, Савранському — 1:3887, Ренійському - 1:4034, Арцизькому - 1:4796 і Окнянському - 1:4915 районах. За даними геохімічного та геофізичного картування Одеського регіону вищевказані райони розташовані на місцевості, що має несприятливі екологічні фрактори: гравітаційної та магнітної аномалії; точкових аномальних вмістів урану, радону, міді, свинцю, ртуті, стронцію, америцію на тлі збідненого вмісту в ґрунтах цинку, молібдену і кобальту; розломи земної кори, структурно-тектонічні і гідрогеологічні аномалії.

Висновки. Встановлено факт існування ДГР-пов'язаних біогеохімічних провінцій в Одеському регіоні. Продовження досліджень у цьому напрямку є перспективним і виправданим з точки зору вдосконалення стратегій профрілактики і діагностики ДГР.

Ключові слова: дефіцит гормону росту, захворюваність, географічна поширеність, біогеохімічні провінції. 


\section{Введение}

3 адержка роста у детей представляет распространенную и значимую медико-социальную проблему, в основе которой лежат самые разнообразные причинные факторы, в том числе условия окружающей среды [21]. Настоящее исследование посвящено особенностям географической распространенности в Одесской области тяжелого нарушения роста у детей, обусловленного дефицитом гормона роста (ДГР). В Украине изучение распространенности ДГР у детей носит эпизодический характер и включает ряд региональных отрывочных данных об общей и первичной заболеваемости. Ранняя инвалидизация детей с ДГР, сложность диагностики и высокая стоимость реабилитационных мероприятий диктуют необходимость организации правильной мониторинговой деятельности в оценке психофизического развития детей.

Актуальным направлением исследований является ауксологический подход [18], который позволяет включить в анализ рисковых факторов роста внешние биогеохимические влияния.

Ауксология (от греч. Auхапо - расти) изучение процесса роста и развития человека. Термин относится к изучению биологического роста и применяется для характеристики различных аспектов ростового процесса [1]. Одним из важных разделов ауксологии является исследование популяционных аспектов роста (онтогенетические, эпидемиологические, экологические и др.) - как отражение условий жизни той или иной человеческой популяции $[17,18]$.

В ряде исследований $[2,7,13,15]$ было показано влияние особенностей биохимического и биофизического состава почв различных территорий на рост и развитие растительного и животного мира, включая влияние на здоровье человека. Подобные территории в конце прошлого века академик А.П. Виноградов предложил называть биогеохимическими провинииями (БГХП) [2]. Особенность таких областей на поверхности Земли состоит в различии содержания (в почвах, водах и т. д.) химических соединений, с которыми связаны определенные биологические реакции со стороны местной флоры и фауны. Существуют БГХП, обедненные медью, кальцием, марганцем, кобальтом; обогащенные свинцом, ураном, молибденом, марганцем, медью и другими элементами [10].

Примером может служить Закарпатская область, представляющая БГХП с резким недостатком йода, где наблюдается развитие эндемии зоба. Ряд исследователей включают в БГХП территории, в которых резкая недостаточность или избыточность содержания каких-либо химических элементов в среде может быть обусловлена деятельностью человека, вызывая в пределах данной территории биогеохимические эндемии - заболевания растений, животных и человека [14].

В крупномасштабном исследовании [11], посвященном оценке влияния химических элементов ландшафтных комплексов Украины на здоровье людей, отмечается, что Одесский регион располагается на территории хоперского регионального геохимического ландшафта и относится к эколого-геохимической провинции, обедненной цинком ( $\mathrm{Zn})$, молибденом (Mo) и кобальтом (Co): «Zn, Mo, Co - провинция» в Лесостепной и Заднестровской зонах [11].

Медико-экологический анализ недостатка указанных микроэлементов в грунтовом покрытии выявил наличие обратной связи с частотой встречаемости ряда заболеваний у детей, что позволило исследователям предложить для оценки заболеваемости коэффициент контрастности распространения заболевания [11]. Стойкое превышение указанного коэффициента на изучаемой территории в течение нескольких лет может, по мнению авторов, служить прогностическим критерием для биогеохимического субрегиона (или БГХП, по А.П. Виноградову [2]). Подобный подход использован в работе, выполненной на территории Одесской области, где авторы выделяют зоны повышенной заболеваемости населения в том случае, если её показатели в 1,5 и более раз превышают среднеобластное значение [5]. Выявлено, что для субрегионов с дефицитом $\mathrm{Zn}, \mathrm{Mo}$, Со такие болезни у детей, как анемии, нефриты и диабет, могут носить характер эндемии. Это предположение получило подтверждение на примере 10 административных территорий Украины: Днепропетровской, Запорожской, Ивано-Франковской, Ровенской, Житомирской, Киевской, Черниговской, Черкасской, Полтавской и Донецкой.

Территория севера Одесской области, по данным «Карты радиационного загрязнения территории Украины» [6], относится к неблагополучной области по облучению населения цезием 137, стронцием, амерцием и радоном. Международным агентством по исследованию рака радон отнесен к канцероге- 
нам I класса, ответственным за возникновения рака легких у некурящих людей [4].

С геолого-географической точки зрения Одесский регион характеризуется обширной территорией, расположенной в Причерноморской низменности и вытянутой с севера на югозапад. Он включает 25 административных районов и ряд природных географических зон, отличающихся рельефом, составом почв, ископаемых пород, видом растительного мира и типами хозяйственной деятельности населения районов области. При самых различных подходах к описанию географии Одесской области различные авторы выделяют три основные зоны (табл. 1): Лесостепную, Степную и Заднестровскую, или Заднестровье. Эти зоны отличаются геологическими, экологическими и социо-экономическими параметрами $[8,9,16]$.
По данным геологических исследований, проведенных в 1985-1990 годах, на территории Одесской области выявлен ряд структурногеологических, геофизических, ландшафтногеологических и гидрогеохимических аномалий (последние включают зоны техногенного происхождения). Наиболее известны и изучены следующие аномалии и зоны поражений, связанные с нарушением баланса химических элементов в воде, почве и атмосфере: гравитационные, магнитные и структурно-тектонические аномалии; зоны спрединга; точечные и площадные аномалии содержаний урана, радона, меди, свинца, ртути, стронция и амерция; гидрогеологические аномалии техногенного происхождения (табл. 1). Результаты исследования легли в основу концепции т.н. «медико-геологических аномалий» [5] -

Геофизические и гидрогеологические аномалии в Одесском регионе [5]

Таблища 1 Лесостепная зона

\begin{tabular}{|c|c|}
\hline \multicolumn{2}{|r|}{ Лесостепная зона } \\
\hline $\begin{array}{c}\text { Административные } \\
\text { районы }\end{array}$ & \multirow{8}{*}{$\begin{array}{l}\text { 1. Балтско-Ананьевская гравимагнитная аномалия интенсивностью до } 13000 \text { гамм и 15-20 мГал. } \\
\text { 2. Савранско-Любашевская магнитная аномалия интенсивностью до 8000-14 000 гамм. } \\
\text { Мозаичное гравитационное поле до 20-30 мГал. } \\
\text { 3. Точечные и площадные аномалии содержаний урана, радона, меди, свинца и ртути, стронция, } \\
\text { америция. } \\
\text { 4. Хоперский региональный геохимический ландшафрт, обедненный цинком (Zn), молибденом } \\
\text { (Мо) и кобальтом (Со). }\end{array}$} \\
\hline Ананьевский & \\
\hline Балтский & \\
\hline Кодимский & \\
\hline Подольский & \\
\hline Окнянский & \\
\hline Любашовский & \\
\hline Савранский & \\
\hline \multicolumn{2}{|r|}{ Степная зона } \\
\hline $\begin{array}{c}\text { Административные } \\
\text { районы }\end{array}$ & \multirow{8}{*}{$\begin{array}{l}\text { 5. Захарьевско-Великомихайловская магнитная аномалия до 3000-8000 гамм. } \\
\text { Гравитационное поле } 20-40 \text { мГал. } \\
\text { 6. Ивановско-Ширяевская аномалия - гравитационная аномалия сложного строения. } \\
\text { Отрицательная гравитационная аномалия 15-20 мГал. Чередование крупных отрицательных } \\
\text { магнитных аномалий с мелкими положительными аномалиями 150-400 гамм. } \\
\text { 7. Захарьевская гидрогеологическая аномалия в сочетании с загрязнением почв ядохимикатами. } \\
\text { 8. Гвоздавский разлом (территория Любашевского, Николаевского и Березовского районов) - } \\
\text { зона повышенной проницаемости земной коры. }\end{array}$} \\
\hline Березовский & \\
\hline В.-Михайловский & \\
\hline Ивановский & \\
\hline Николаевский & \\
\hline Роздельнянский & \\
\hline Захарьевский & \\
\hline Ширяевский & \\
\hline \multicolumn{2}{|r|}{ Заднестровская зона } \\
\hline $\begin{array}{c}\text { Административные } \\
\text { районы }\end{array}$ & \multirow{14}{*}{$\begin{array}{l}\text { 9. Лиманская гидрогеологическая аномалия, сочетанная с загрязнением почв ядохимикатами. } \\
\text { 10. Арциз-Татарбунарская зона - структурно-тектонические аномалии, гидрогеологические } \\
\text { аномалии, загрязнение почв ядохимикатами. } \\
\text { 11. Чадырлунгский надвиг (участки Арцизского и Татарбунарского районов) - } \\
\text { границы Восточно-Европейской платформы и Скифокой плиты. Зона спрединга } \\
\text { (Скифская плита уходит под платформу). } \\
\text { 12. Белгород-Днестровская гидрогеологическая аномалия. } \\
\text { 13. Килийская гидрогеологическая аномалия. } \\
\text { 14. Болградский надвиг (Участки Болградского, Измаильского и Килийского районов). } \\
\text { Зона спрединга с генерацией землетрясений, термальных источников. } \\
\text { 15. Точечные и площадные аномалии содержаний урана. } \\
\text { 16. Хоперский региональный геохимический ландшафт обедненный цинком (Zn), } \\
\text { молибденом (Мо) и кобальтом (Со). }\end{array}$} \\
\hline Арцизский & \\
\hline Беляевский & \\
\hline Болградский & \\
\hline Б.-Днестровский & \\
\hline Измаильский & \\
\hline Килийский & \\
\hline Лиманский & \\
\hline Овидиопольский & \\
\hline Ренийский & \\
\hline Саратский & \\
\hline Тарутинский & \\
\hline Татарбунарский & \\
\hline г. Одесса & \\
\hline
\end{tabular}


зон с повышенной заболеваемостью населения какими-либо нозоформами. Наличие подобных территориальных особенностей Одесской области позволяет высказать гипотезу о возможном существовании ДГР-связанных БГХП на территории Одесского региона, которые можно выявить на основе изучения кумулятивной встречаемости ДГР у детей в различных геоэндемических территориальных образованиях.

Целью настоящей работы является изучение общей и первичной заболеваемости ДГР, сроков его выявления, территориальной распространенности в различных природных физико-географических зонах и БГХП Одесского региона.

Объектом исследования является эпидемиология ДГР в Одесской области.

Предмет исследования - картографическая привязка каждого случая подтвержденного диагноза ДГР.

\section{Материал и методы исследования}

Изучены данные обследований диспансерной группы детей с ДГР, отраженные в амбулаторных картах эндокринологического центра Одесской областной детской клинической больницы (ООДКБ). Диагноз ДГР формулировался на основании исследований соматического статуса, лабораторных данных (в том числе результатов гормонального профиля) и данных инструментального обследования (в том числе костный возраст, состояние турецкого седла).

Структура низкорослости контингента консультативного поликлинического отделения Одесской областной детской клинической больницы в 2017 г.

\begin{tabular}{|c|c|c|}
\hline \multirow{2}{*}{ Причина низкорослости } & \multicolumn{2}{|c|}{$\begin{array}{c}\text { Количество выявленных } \\
\text { нарушений роста }(n=450)\end{array}$} \\
\hline & абс. & \% от всей группы \\
\hline Эндокринопатии & 102 & 22,66 \\
\hline $\begin{array}{l}\text { Гастроинтестинальные } \\
\text { заболевания }\end{array}$ & 53 & 11,77 \\
\hline Респираторные заболевания & 62 & 13,77 \\
\hline Кардиальная патология & 40 & 8,89 \\
\hline Почечная патология & 5 & 1,11 \\
\hline Наследственная патология & 66 & 14,67 \\
\hline $\begin{array}{l}\text { Психосоциальная низкоро- } \\
\text { слость (в т.ч. психологическая } \\
\text { и фризическая жестокость, } \\
\text { запущенность) }\end{array}$ & 8 & 1,78 \\
\hline $\begin{array}{l}\text { Идиопатический низкий рост } \\
\text { (в т.ч. семейный низкий рост } \\
\text { и конституциональная } \\
\text { задержка роста и развития) }\end{array}$ & 112 & 24,88 \\
\hline Всего & 450 & 100 \\
\hline
\end{tabular}

Поликлиническое обследование детей с нарушениями роста включало использование следующих методов:

1. Измерение роста проводилось по общепринятой методике с точностью до десятых долей сантиметра с последующей оценкой физического развития детей по данным перцентильных таблиц нормативных показателей стандартов роста и веса для мальчиков и девочек [19,22].

2. Для оценки отличия исследуемого параметра от средних значений рассчитывался коэффициент стандартного отклонения (standard deviation score, SDS).

3. Показатель встречаемости (частота встречаемости, коэффициент встречаемости) рассчитывали как отношение числа выявленных детей с ДГР по отношению ко всей популяции детей изучаемого района.

4. Показатель общей заболеваемости детей с ДГР по районам, учитывая редкость заболевания и сложившуюся международную практику, рассчитывался в пересчете на 100 тыс. детского населения [3,23].

\section{Результаты исследований}

Собственное исследование. В 2017 году поликлиническое отделение (ООДКБ) посетило 76528 детей, в том числе по поводу ростовых нарушений различного происхождения 450 детей, что составило 0,59\% от всех обращений (табл. 2). Из этого контингента на основе анализа амбулаторных карт были отобраны карты, содержащие полные сведения о 62 пациентах с ДГР.

Критериями включения являлось наличие достоверных данных о том, что диагноз ДГР подтвержден клинико-лабораторными методами, четко указано время постановки диагноза, что посетившие ООДКБ дети родились в Одесской области и указан конкретный административный район проживания.

Из анализа исключены дети с ДГР, находящиеся под наблюдением ООДКБ, но переехавшие в Одесскую область из других областей Украины, а также дети с нарушениями роста по иной медико-биологической причине.

При расчетах общей заболеваемости детей ДГР учитывались данные областного статистического управления о количестве детей по районам Одесской области на 2017 год. Анализ встречаемости ДГР у детей проведен по каждому административному и геолого-географическому делению Одесской области.

На 31 декабря 2017 г. в Одесской области детское население (от 0 до 17 лет) составило 457 
Численность детского населения, общая заболеваемость и распространенность ДГР

Таблища 3 по административным районам и географическим зонам Одесской области

\begin{tabular}{|c|c|c|c|c|c|c|c|c|c|}
\hline \multirow[t]{2}{*}{ Административные районы области } & \multicolumn{3}{|c|}{$\begin{array}{c}\text { Детское население } \\
\text { от } 1 \text { до } 17 \text { лет }\end{array}$} & \multicolumn{3}{|c|}{$\begin{array}{c}\text { Общая } \\
\text { заболеваемость }\end{array}$} & \multicolumn{3}{|c|}{$\begin{array}{l}\text { Кумулятивная } \\
\text { встречаемость }\end{array}$} \\
\hline & Мал. & Дев. & Bcero & Мал. & Дев. & Bcero & Мал. & Дев. & Bcero \\
\hline \multicolumn{10}{|c|}{ Лесостепная зона } \\
\hline Ананьевский & 2843 & 2642 & 5485 & 70,35 & 37,85 & 54,69 & $1: 1421$ & $1: 2642$ & $1: 1828$ \\
\hline Балтский & 4280 & 3930 & 8210 & 23,36 & 0,00 & 12,18 & $1: 4280$ & 0,00 & $1: 8210$ \\
\hline Кодимский & 2905 & 2700 & 5605 & 34,42 & 0,00 & 17,84 & $1: 2905$ & 0,00 & $1: 5605$ \\
\hline Подольский & 6975 & 6354 & 13329 & 28,67 & 0,00 & 15,00 & $1: 3487$ & 0,00 & $1: 6664$ \\
\hline Окнянский & 2541 & 2374 & 4915 & 0,00 & 42,12 & 20,35 & 0,00 & $1: 2374$ & $1: 4915$ \\
\hline Любашовский & 3369 & 3191 & 6560 & 29,68 & 0,00 & 15,24 & $1: 3369$ & 0,00 & $1: 6560$ \\
\hline Савранский & 1890 & 1997 & 3887 & 52,91 & 0,00 & 25,73 & $1: 1890$ & 0,00 & $1: 3887$ \\
\hline Всего по Лесостепной зоне & 24803 & 23188 & 47991 & 32,25 & 8,63 & 20,84 & $1: 3100$ & $1: 11594$ & $1: 4799$ \\
\hline \multicolumn{10}{|c|}{ Степная зона } \\
\hline Березовский & 3986 & 3714 & 7700 & 0,00 & 0,00 & 0,00 & 0,00 & 0,00 & 0,00 \\
\hline В.-Михайловский & 3909 & 3816 & 7725 & 0,00 & 0,00 & 0,00 & 0,00 & 0,00 & 0,00 \\
\hline Ивановский & 3380 & 3221 & 6601 & 29,59 & 0,00 & 15,15 & $1: 3380$ & 0,00 & $1: 6601$ \\
\hline Николаевский & 1966 & 1846 & 3812 & 50,86 & 0,00 & 26,23 & $1: 2000$ & 0,00 & $1: 3800$ \\
\hline Роздельнянский & 6886 & 6319 & 13205 & 0,00 & 15,83 & 7,57 & 0,00 & $1: 6300$ & $1: 13000$ \\
\hline Захарьевский & 2726 & 2595 & 5321 & 0,00 & 0,00 & 0,00 & 0,00 & 0,00 & 0,00 \\
\hline Ширяевский & 3371 & 3140 & 6511 & 0,00 & 0,00 & 0,00 & 0,00 & 0,00 & 0,00 \\
\hline Всего по Степной зоне & 26224 & 24651 & 50875 & 7,63 & 4,06 & 5,90 & $1: 13112$ & $1: 24651$ & $1: 16958$ \\
\hline \multicolumn{10}{|c|}{ Заднестровская зона } \\
\hline Арцизский & 17142 & 16126 & 33268 & 39,77 & 0,00 & 20,85 & $1: 2514$ & 0,00 & $1: 4796$ \\
\hline Беляевский & 13501 & 12791 & 26292 & 14,81 & 15,64 & 15,21 & $1: 6750$ & $1: 6395$ & $1: 6573$ \\
\hline Болградский & 7308 & 6828 & 14136 & 0,00 & 0,00 & 0,00 & 0,00 & 0,00 & 0,00 \\
\hline Б.-Днестровский & 13284 & 12671 & 25955 & 22,58 & 7,89 & 15,41 & $1: 4428$ & $1: 12671$ & $1: 6488$ \\
\hline Измаильский & 13171 & 12225 & 25396 & 15,18 & 0,00 & 7,88 & $1: 6585$ & 0,00 & $1: 12698$ \\
\hline Килийский & 5829 & 5436 & 11265 & 17,16 & 18,40 & 17,75 & $1: 5829$ & $1: 5436$ & $1: 5632$ \\
\hline Лиманский & 10892 & 10263 & 21155 & 27,54 & 0,00 & 14,18 & $1: 3630$ & 0,00 & $1: 7051$ \\
\hline Овидиопольский & 17142 & 16126 & 33268 & 5,83 & 6,20 & 6,01 & $1: 17142$ & $1: 16126$ & $1: 16634$ \\
\hline Ренийский & 4126 & 3942 & 8068 & 24,24 & 25,37 & 24,79 & $1: 4126$ & $1: 3942$ & $1: 4034$ \\
\hline Саратский & 5637 & 5241 & 10878 & 0,00 & 0,00 & 0,00 & 0,00 & 0,00 & 0,00 \\
\hline Тарутинский & 5439 & 5067 & 10506 & 18,39 & 0,00 & 9,52 & $1: 5439$ & 0,00 & $1: 10506$ \\
\hline Татарбунарский & 4481 & 4423 & 8904 & 22,32 & 0,00 & 11,23 & $1: 4481$ & 0,00 & $1: 8904$ \\
\hline г. Одесса & 78549 & 74981 & 153530 & 25,46 & 8,01 & 16,93 & $1: 3900$ & $1: 12500$ & $1: 5900$ \\
\hline Всего по Заднестровской зоне & 184388 & 174557 & 358945 & 20,07 & 6,87 & 13,65 & $1: 4983$ & $1: 14546$ & $1: 7325$ \\
\hline \multicolumn{10}{|c|}{ Всего по Одесской области (включая города обл. значения) } \\
\hline Всего по Одесской области & 235415 & 222396 & 457811 & 19,96 & 6,74 & 13,54 & $1: 5008$ & $1: 14826$ & $1: 7384$ \\
\hline
\end{tabular}

811 детей, включая 235415 мальчиков и 222396 девочек. На диспансерном учете по ДГР в ООДКБ находилось 62 ребенка, что соответствовало частоте распространенности заболевания 62:457 811, или 1:7384. Подобное соотношение описано и в ряде зарубежных работ [20,23].

Как видно из табл. 3, среди детей Одесской области с ДГР мальчики значительно преобладают над девочками. Соотношение количества больных детей (мальчики/девочки) составило: в Лесостепной зоне $-4: 1$ в В Сепной зоне $-2: 1$ и Заднестровской $-3,1: 1$. В г. Одессе соотношение между мальчиками и девочками с ДГР составило 3,3:1. В целом по региону это соотношение равно $3,1: 1$.
Общая заболеваемость ДГР в Одесской области составила в 2017 г. 13,54 на 100 тыс. детского населения. Для Лесостепной зоны этот показатель составил 20,84, для Степной зоны - 5,90 и для Заднестровской зоны 13,65. В г. Одессе общая заболеваемость детей ДГР составила 16,93.

В пределах Лесостепной зоны высокая общая заболеваемость отмечена в Ананьевском $(54,69)$, Окнянском $(20,35)$ и Савранском $(25,73)$ районах. Также в Ананьевском и Савранском районах отмечена самая высокая заболеваемость у мальчиков - 70,35 и 52,91 соответственно. У девочек самый высокий уровень заболеваемости $(42,12)$ отмечен в Окнян- 
ском районе, также территориально расположенном в Лесостепной зоне.

Как следует из данных табл. 3, в Одесской области для детей обоего пола «накопленная» (кумулятивная) встречаемость [12] составила 1 случай ДГР на 7384 детского населения. Для мальчиков этот показатель составил 1:5008, а для девочек - 1:14826. Максимальная встречаемость отмечена у мальчиков Лесостепной зоны - 1:3100.

В пределах Лесостепной зоны пик встречаемости ДГР отмечен в Ананьевском районе, где его уровень составил: для детей обоего пола - 1:1828; для мальчиков 1:1421; для девочек 1: 2642.

В Степной зоне наиболее высокая общая заболеваемость и кумулятивная встречаемость ДГР отмечается в Николаевском районе: 26,23 и 1:3800 соответственно.

В Заднестровской зоне показатели общей заболеваемости и кумулятивной встречаемости наиболее высоки в Арцизском (20,85 и 1:4796) и Ренийском районах (24,79 и 1:4034).

В 2017 г. впервые выявлено 18 новых случаев ДГР у детей, в том числе 11 случаев в г. Одессе и 7 случаев в районах области. Первичная заболеваемость (количество новых случаев в 2017 г. в пересчете на 100 тыс. детского населения) для Одесского региона составила 3,93. Для Лесостепной зоны первичная заболеваемость составила 4,16, для Степной зоны 0,00 и для Заднестровья - 2,43.

Возраст детей при постановке на диспансерный учет по Одесскому региону составил в среднем 7,83 $\pm 3,50$ года: для мальчиков

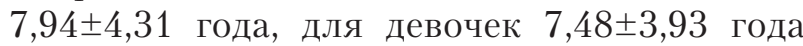
(p>0,05). На рисунке представлены данные о возрастных периодах, в которых диагноз ДГР был выставлен впервые.

Существуют гендерные отличия в показателях постановки на учет детей с ДГР. Так, у мальчиков пик выявляемости ДГР приходится на возрастной период 5-7 и 13-15 лет, а у девочек - на период 9-11 лет.

\section{Обсуждение}

Ранняя диагностика ДГР (у 12 детей первых трех лет жизни) составила лишь 19,35\% от всех выявленных заболеваний (62 случая ДГР). В возрасте до 7 лет выявлено 26 из 62 случаев ДГР (41,93\%), что составляет менее половины подтвержденных клинических случаев. Соотношение количества больных детей (мальчики/девочки) составило по Одесскому региону 3,1:1, что соответствует распространенности заболевания в других странах. Так, в США, по данным A.W. Root с соавт. [24], среди детей с идиопатическим ДГР мальчиков 73\%, девочек 27\% (соотношение 2,7:1), а среди детей с ДГР органического генеза $62 \%$ мальчиков и $38 \%$ девочек (соотношение 1,6:1).

Проведенное исследование показало актуальность ранней диагностики ДГР у детей. Недостаточное и позднее выявление заболевания в Одесском регионе подчеркивает необходимость своевременного и правильного измерения и регистрации физического развития детей с оценкой степени развития по региональной центильной морфометрической шкале для детей дошкольного возраста.

Необходим контроль над ведением отчетной документации учреждений здравоохранения первичного звена на предмет своевременного определения и анализа физического развития детского населения дошкольного возраста. Значительное количество пациентов, обращающихся по поводу задержки роста в эндокринологическое отделение, - это дети пубертатного возраста. Подобный факт свидетельствует, с одной стороны, о низкой настороженности врачей-педиатров первичного звена в отношении низкорослости у детей, с другой - о недостаточной компетентности родителей в отношении оценки гармоничности развития собственных детей [23].

Гендерный анализ (доминирование мальчиков в структуре пациентов) отражает большую психологическую значимость проблемы низкорослости для лиц мужского пола, в наибольшей степени выраженную в школьном возрасте.

Интересен факт неоднородного распределения больных с ДГР по территории Одесского региона. Превышение среднеобластного уровня общей заболеваемости ДГР в 1,5 и более раз выявлено в шести районах - Ананьевском, Окнянском, Савранском, Николаевском, Арцизском и Ренийском. Картографическое сопоставление этих районов с данными геохимических исследований показывает, что все они расположены в местностях, неблагополучных по экологическим параметрам. Так, Ананьевский, Окнянский и Савранский районы расположены на территории гравимагнитной аномалии и точечных аномальных содержаний урана, радона, меди, свинца, ртути, стронция, амерция на фоне обедненного содержания в почвах цинка, молибдена и кобальта. Николаевский район - на территории Гвоздав- 


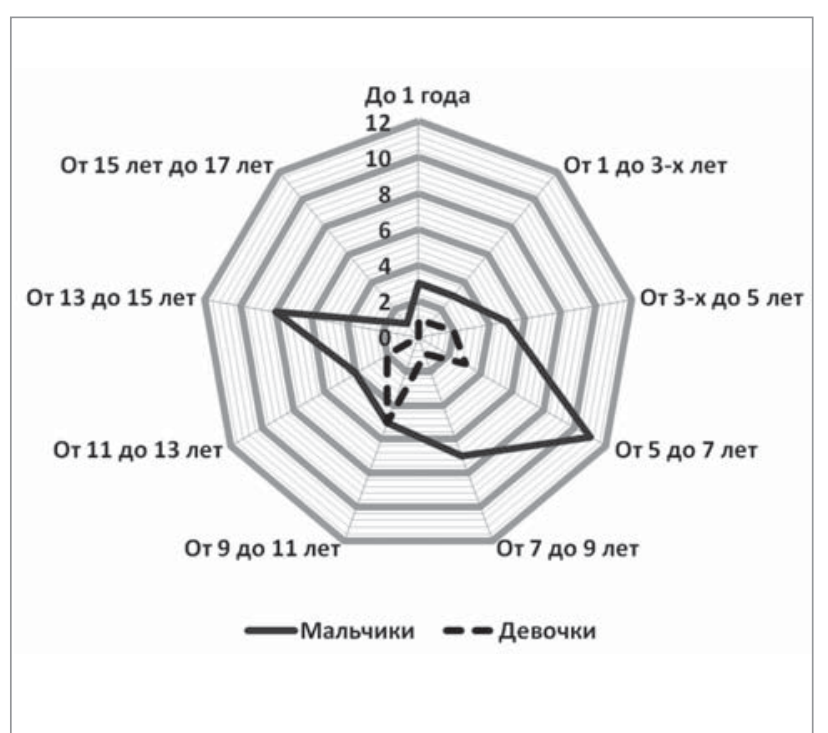

Pис. Сроки выявления ДГР у детей Одесского региона (2017 г.)

ского разлома земной коры, сопровождающегося повышенной проницаемостью для геологических процессов. Арцизский и Ренийский районы расположены в местностях, характеризующихся структурно-тектоническими и гидрогеологическими аномалиями, зоной спрединга (надвиг Восточно-Европейской платформы на Скифскую плиту) с генерацией землетрясений и термальных источников. Геохимический ландшафт этих районов также обеднен цинком, молибденом и кобальтом.
Указанные закономерности позволяют отнести эти районы к ДГР-связанным БГХП Одесского региона.

Полученные данные согласуются с ранее известными фактами повышенной регистрации в отдельных местностях ряда эндемических болезней в связи с определенными природными особенностями местности [10].

Обнаруженная неоднородность распределения больных с ДГР в различных природных зонах Одесского региона требует дальнейшего изучения. Не исключено неблагоприятное воздействие факторов БГХП на другие органы и системы организма ребенка и формирование иных устойчивых очагов повышенной заболеваемости.

\section{Выводы}

Настоящим исследованием установлен факт существования ДГР-связанных БГХП в Одесском регионе.

Продолжение исследований в этом направлении является перспективным и оправданным с точки зрения совершенствования стратегий профилактики и диагностики ДГР. Возможно, что геоэндемический подход позволит углубить представления о патогенезе и клинической сути некоторых случаев гипофизарного нанизма у детей.

Авторы заявляют об отсутствии конфликта интересов.

\section{ЛИТЕРАТУРА}

1. Ауксология. https://ru.wikipedia.org/wiki/Ауксология.

2. Виноградов АП. Горная энциклопедия. http://www.miningenc.ru/v/vinogradov-ap/

3. Воронцова MB. (2016). Заболеваемость гипофизарным нанизмом в Российской Федерации по данным официальной медицинской статистики и Регистра пациентов с гипофизарным нанизмом. Проблемы эндокринологии. 4:18-26. doi 10.14341/probl201662418-26.

4. Диденко ПИ. (2004). Экологические аспекты воздействия радона на население. У зб. наук. пр. Техногенно-екологічна безпека та цивільний захист. 6: 72-81.

5. Кадастры и атлас карт медико-геологических аномалий на территории Одесской области. (1991). Одесса: 177.

6. Карты радиационного загрязнения территории Украины. https://www.imbf.org/karty/karta-radiacionnogo-zagrjaznenijaukrainy.html

7. Кауричев ИС, Панов НП, Розов НН и др. (1989). Почвоведение. 4-е изд, прераб. и доп. Москва: Агрономиздат: 719.

8. Одесская область. http://geosfera.org/evropa/ukraina/1765-odesskaya-oblast.html.

9. Перевалов В. (2016). Геопатогенные зоны и сети. В кн: Одесская геомагнитная аномалия и геопатогенные зоны. Одесса: 16-28.
10. Понятия о биогеохимических провинциях и геохимических заболеваниях. http://ru-ecology.info/static/pngbig /633685166.png.

11. Рудько ГІ, Адаменко ОМ (ред.). (2010). Вступ до медичної геології. Київ: Академпрес. 2:448.

12. Словарь социологической статистики (2004). https://sociological_statistics.academic.ru/133/накопленная_кумулятивная_частота.

13. Снакин ВВ. (2000). Экология и охрана природы. Словарь-справочник. Москва: Academia: 384.

14. Сохранение и восстановление биоразнообразия. (2002). Москва: Изд-во Научного и учебно-методич центра: 286

15. Степановских АС. (2000). Общая экология: Учебник для вузов. Москва: ЮНИТИ-ДАНА: 510.

16. Топчиев АГ, Михайлова НП, Молдецкий АЄ, Нефедова НЕ, Полоса АИ и др. (1991). Одесская область: Территориальная организация и структура хозяйства. Концепция социально-экономического развития. Одесса: Маяк: 312

17. Харитонов ВМ, Ожигова АП, Година ЕЗ. (2004). Ауксология. Антропология. Учебник для вузов. Москва: Владос:113.

18. Bozzola M, Meazza C. (2014). Growth hormone deficiency: diagnosis and therapy in children. Expert Review of Endocrinology \& Metabolism: 5: 273-284. 
19. Cooke DW, Divall SA, Radovick S. (2016). Normal and aberrant growth in children. In: Melmed S, Polonsky KS, Larsen PR, Kronenberg HM, eds. Williams Textbook of Endocrinology. 13th ed. Philadelphia, PA: Elsevier Saunders: chap 24

20. Genetics Home Reference: combined pituitary hormonedeficiency. National Library of Medicine. https://ghr.nlm.nih.gov/.../combined-pituitary-hormone-deficiency - External Health Links.

21. Grimberg A, DiVall SA, Polychronakos $C$ et al. (2016). Guidelines for growth hormone and insulin-like growth factor-I treatment in children and adolescents: growth hormone deficiency, idiopathic short stature, and primary insulin-like growth factor-I deficiency. Horm Res Paediatr: 86(6): 361-397.

22. Growth hormone deficiency in children. https://bestpractice.bmj.com/topics/en-us/839.

23. John M, Koledova E, Kumar KMP, Chaudhari H. (2016). Challenges in the Diagnosis and Management of Growth Hormone Deficiency in India. International Journal of Endocrinology. Article ID 2967578: 1-11

24. Root AW, Kemp SF, Rundle AC. (1998). Effect of long-term recombinant growth hormone therapy in children - the National Cooperative Growth Study. J Pediatr Endocrinol Metab: 11:403-12.

\section{Сведения об авторах:}

Сеньковская Людмила Ивановна - к.мед.н., ассистент каф. педиатрии №1 Одесского НМУ Адрес: г. Одесса, Валиховский переулок 2

Бирюков Виктор Сергеевич - к.мед.н., доц. каф. педиатрии №1 Одесского НМУ Адрес: г. Одесса, Валиховский переулок 2.

Аряев Николай Леонидович - чл.-корр. НАМН Украины, д.мед.н., зав. каф. педиатрии №1 Одесского НМУ Адрес: г. Одесса, Валиховский переулок 2.

Статья поступила в редакцию 09.11.2018 г.; принята в печать 12.03.2019 г.

\section{ДО УВАГИ АВТОРІВ!}

\section{AЛТОРИТМ РЕССТРАДIÏ ORCID}

\section{Open Researcher and Contributor ID (ORCID) - міжнародний ідентифікатор науковця}

Створення єдиного реєстру науковців та дослідників на міжнародному рівні є найбільш прогресивною та своєчасною ініціативою світового наукового товариства. Ця ініціатива була реалізована через створення в 2012 році проекту Open Researcher and Contributor ID (ORCID). ORCID - це реєстр унікальних ідентифікаторів вчених та дослідників, авторів наукових праць та наукових організацій, який забезпечує ефективний зв'язок між науковцями та результатами їх дослідницької діяльності, вирішуючи при цьому проблему отримання повної і достовірної інформації про особу вченого в науковій комунікації.

Для того щоб зареєструватися в ORCID через посилання https://orcid.org/ необхідно зайти у розділ «For researchers» і там натиснути на посилання «Register for an ORCID iD».

В реєстраційній формі послідовно заповнюються обов'язкові поля: «First name», «Last name», «E-mail», «Re-enter E-mail», «Password» (Пароль), «Confirm password»

В перше поле вводиться ім'я, яке надане при народженні, по-батькові не вводиться. Персональна електронна адреса вводиться двічі для підтвердження. Вона буде використовуватися як Login або ім'я користувача. Якщо раніше вже була використана електронна адреса, яка пропонується для реєстрації, з'явиться попередження червоного кольору. Неможливе створення нового профілю з тією ж самою електронною адресою. Пароль повинен мати не менше 8 знаків, при цьому містити як цифри, так і літери або символи. Пароль, який визначається словами «Good» або «Strong» приймається системою..

Нижче визначається «Default privacy for new works», тобто налаштування конфіденційності або доступності до персональних даних, серед яких «Public», «Limited», «Private».

Далі визначається частота повідомлень, які надсилає ORCID на персональну електронну адресу, а саме, новини або події, які можуть представляти інтерес, зміни в обліковому записі, тощо: «Daily summery», «Weekly summery», «Quaterly summery», «Never». Необхідно поставити позначку в полі «I'm not a robot» (Я не робот).

Останньою дією процесу реєстрації є узгодження з політикою конфіденційності та умовами користування. Для реєстрації необхідно прийняти умови використання, натиснувши на позначку «I consent to the privacy policy and conditions of use, including public access and use of all my data that are marked Public».

Заповнивши поля реєстраційної форми, необхідно натиснути кнопку «Register», після цього відкривається сторінка профілю учасника в ORCID з особистим ідентифікатором ORCID ID. Номер ORCID ідентифікатора знаходиться в лівій панелі під ім'ям учасника ORCID.

Структура ідентифікатора ORCID являє собою номер з 16 цифр. Ідентифікатор ORCID - це URL, томy запис виглядає як http://orcid.org/xxxx-xxxx-xxxxxxxx.

Наприклад: http://orcid.org/0000-0001-7855-1679.

Інформацію про ідентифікатор ORCID необхідно додавати при подачі публікацій, документів на гранти і в інших науково-дослідницьких процесах, вносити його в різні пошукові системи, наукометричні бази даних та соціальні мережі.

Подальша робота в ORCID полягає в заповненні персонального профілю згідно із інформацією, яку необхідно надавати. 
УДК 616.2-039.41-053.2:616.329-002-008.843.3

\title{
Т.В. Починок', О.В. Журавель', О.В. Чернов ${ }^{2}$ Вміст оксиду азоту та його метаболітів у крові та слизовій стравоходу у дітей з частими респіраторними захворюваннями на тлі гастроезофагеальної рефлюксної хвороби
}

\author{
${ }^{2}$ ДУ «Інститут педіатрії, акушерства та гінекології імені академіка О.М. Лук'янової НАМН України», м. Київ
}

SOVREMENNAYA PEDIATRIYA.2019.2(98):31-34; doi 10.15574/SP.2019.98.31

Оксид азоту забезпечує вазодилатацію кровоносних судин, регуляцію мікроциркуляції, синтезу і секреції гормонів, що впливають на моторику шлунково-кишкового-тракту (ШКТ), шлункову секрецію. $€$ поодинокі дослідження, які підтверджують гастропротекторний ефект цього медіатора на пошкоджену слизову. B інших джерелах відзначається порушення моторики шлунка при блокуванні NO-синтази.

Мета - дослідити рівень оксиду азоту та його метаболітів у плазмі крові та слизовій стравоходу у дітей з частими респіраторними захворюваннями на тлі гастроезофрагальної рефрлюксної хвороби (ГЕРХ)

Матеріали і методи. Обстежено 150 дітей пубертатного віку. Виділено три групи спостереження - діти з ЧРЗ на тлі ГЕРХ (90 дітей, група 1), діти 3 ЧР3 без ГЕРХ (30 дітей, група 2), практично здорові діти (30 дітей, група 3).

Результати. Встановлено вірогідний приріст сумарного NO на 29,5\% у плазмі крові дітей з ЧР3 на тлі ГЕPX, метаболіту нітриту азоту (NO2) — на 27,4\%, метаболіту нітрату азоту (NO3) — на 40,2\%.

У слизовій стравоходу встановлено суттєвий приріст метаболітів оксиду азоту при супутній ГEPX (NO сумарний — у 2,16 разу, NO3- у 2,1 разу, NO2 у 1,59 разу), проте в групі дітей з ЧРЗ без супутньої ГЕРХ вірогідної різниці щодо групи контролю не виявлено.

При регресійному аналізі отримано лінійний прямий зв'язок між вмістом оксиду азоту та його метаболітів у слизовій стравоходу та плазми крові: $r=0,30(p<0,05), N_{2}-r=0,29(p<0,05), N 0_{3}-r=0,34(p<0,05)$.

Висновки. На тлі ГЕРХ встановлено вірогідний приріст оксиду азоту в плазмі крові та слизовій стравоходу, позитивний кореляційний зв'язок загального NO та його метаболітів NO2 та NOз у плазмі та слизовій стравоходу.

Ключові слова: діти з частими респіраторними захворюваннями, гастроезофагеальна ресрлюксна хвороба, оксид азоту, слизова стравоходу, кров.

\section{Content of nitrogen oxide and its metabolites in blood and esophageal mucosa in children sickly with respiratory diseases against the bachground of gastroesophagial reflux disease \\ T.V. Pochinok', O.V. Zhuravel', O.V. Chernov' \\ 'Bogomolets National Medical University, Kyiv, Ukraine}

'SI «Institute of Pediatrics, Obstetrics and Gynecology named after academician 0. Lukyanova of the National Academy of Medical Sciences of Ukraine», Kyiv

Actuality. Nitric oxide provides vasodilatation of blood vessels, regulation of microcirculation, regulation of synthesis and secretion of hormones that affect the gastrointestinal motility (gastrointestinal tract), gastric secretion. There are few studies which confirm gastroprotective effect of this mediator. In other researches signed disorders of stomach motility when blocking NO-synthase.

The aim of research - to set the level of nitric oxide and its metabolites in blood plasma and esophagus mucous membrane in children with frequent respiratory diseases (FRD) and gastroesophageal reflux disease (GERD).

Materials and methods. 150 children of puberty age were examined and divided into three groups — children with frequent respiratory diseases (FRD) and concominant gastroesophageal reflux disease (90 children, group 1), children with FRD without GERD (30 children, group 2), healthy children (30 children, group 3). Abstract. A significant increase of total NO (29.5\%) in children with RRI and GERD, NO2 metabolite (27.4\%) and $\mathrm{NO}_{3}$ metabolite $(40.2 \%)$ was established. It has been found that frequent respiratory infections accompanied with significant increase of total NO and its metabolites in esophageal mucosa - total NO 2.16 times, $\mathrm{NO}_{3}-2.1$ times, $\mathrm{NO}_{2}-1.59$ times, $\mathrm{p}<0.05$; however, in $\mathrm{RRI}$ without GERD there is no significant difference revealed.

After regression analisys it was set direct linear relations between the content nitric oxide and its metabolites in esophagus mucous membrane and blood plasma. The regression between total $\mathrm{NO}$ level in plasma and esophagus mucous membrane was $r=0.30(p<0.05), \mathrm{NO}_{2}-r=0.29(p<0.05), \mathrm{NO} \mathrm{O}_{3}-r=0.34(p<0.05)$. Conclusion. It was set the probable increase of nitric oxide in blood plasma and esophagus mucous membrane in GERD, positive correlation between NO and its metabolites $\mathrm{NO}_{2}$ and $\mathrm{NO}_{3}$ in plasma and mucous membrane.

Key words: children with recurrent respiratory infections, gastroesophageal reflux disease, nitric oxide, esophageal mucosa, blood.

\section{Содержание оксида азота и его метаболитов в крови и слизистой пищевода у детей с частыми респираторными заболеваниями на фоне гастроэзофагеальной рефлюксной болезни Т.В. Починок', Е.В. Журавель', А.В. Чернов ${ }^{2}$ \\ 'Национальный медицинский университет имени А.А. Богомольца, г. Киев, Украина \\ 2ГУ «Институт педиатрии, акушерства и гинекологии имени академика Е.М. Лукьяновой НАМН Украины», г. Киев}

Оксид азота обеспечивает вазодилатацию кровеносных сосудов, регуляцию микроциркуляции, синтеза и секреции гормонов, влияющих на моторику желудочно-кишечного-тракта и желудочную секрецию. Есть единичные исследования, подтверждающие гастропротекторный эсрфект этого медиатора на слизистую оболочку. В других источниках отмечается нарушение моторики желудка при блокировании NO-синтазы. Цель - исследовать уровень оксида азота и его метаболитов в плазме крови и слизистой пищевода у детей с частыми респираторными заболеваниями (ЧРЗ) на фоне гастроэзофагеальной рефлюксной болезни (ГЭРБ). 
Материалы и методы. Обследовано 150 детей пубертатного возраста. Выделены три группы наблюдения: дети с ЧР3 на фроне ГЭРБ (90 детей, группа 1), дети с ЧРЗ без ГЭРБ (30 детей, группа 2), практически здоровые дети (30 детей, группа 3).

Результаты. Установлен достоверный прирост суммарного NO на 29,5\% в плазме крови у детей с ЧР3 на фроне ГЭРБ, метаболита нитрита азота (О2) на 27,4\%, метаболита нитрата азота (NO3) - на 40,2\%.

B слизистой пищевода выявлен существенный прирост метаболитов оксида азота при сопутствующей ГЭРБ (NOобщий - в 2,16 раза, NO3 - в 2,1 раза, N02 - в 1,59 раза), однако в группе детей с ЧР3 без сопутствующей ГЭРБ достоверной разницы относительно группы контроля не выявлено. При регрессионном анализе получена линейная прямая связь между содержанием оксида азота и его метаболитов в слизистой пищевода и плазме крови: $r=0,30(p<0,05), \mathrm{NO}_{2}-r=0,29(p<0,05), \mathrm{NO} 3-r=0,34(p<0,05)$.

Выводы. На фоне ГЭРБ установлен достоверный прирост оксида азота в плазме крови и слизистой пищевода, положительная корреляционная связь между содержанием общего $\mathrm{NO}$ и его метаболитов $\mathrm{NO}_{2}$ и NO3 в плазме и слизистой пищевода.

Ключевые слова: дети с частыми респираторными заболеваниями, гастроэзофагеальная рефлюксная болезнь, оксид азота, слизистая пищевода, кровь.

\section{Вступ}

$\mathrm{O}$ ксид азоту (NO) - біологічний медіатор в організмі людини. Він є високореактивною молекулою і наділений оксидантними властивостями, як безпосередньо, так і у формі більш токсичного пероксинітриту. Ці властивості обумовлюють бактерицидний і цитотоксичний ефекти NO і його захисні якості, які проявляються у стимуляції антимікробної активності і цитотоксичності [8]. У біологічні рідини NO потрапляє внаслідок утворення оксиду азоту та L-цитруліну із L-аргініну та $\mathrm{O}_{2}$ із використанням NADPH під впливом різних ізоферментів синтази оксиду азоту (NOS): як конститутивних - eNOS, nNOS, так і індуцибельної NOS (iNOS), індукція якої здійснюється прозапальними цитокінами (TNF, g-інтерфероном, IL-1b та іншими) [5,7].

Встановлено також, що NO забезпечує вазодилатацію кровоносних судин, регулювання мікроциркуляції, регуляцію синтезу і секреції гормонів, що впливають на моторику шлунково-кишкового-тракту (ШКТ), шлункову секрецію [2,10].

Таким чином, NO може розглядатися як непрямий маркер активації запалення та міорелаксації, він бере участь у патофізіології багатьох захворювань, включаючи респіраторну патологію та гастроезофагеальну рефлюксну хворобу (ГЕРХ). $€$ поодинокі дослідження, які підтверджують гастропротекторний ефект цього медіатора на пошкоджену слизову. В інших джерелах відзначається порушення моторики шлунка при блокуванні NO-синтази [6]. Доведено вплив NO на роботу пілоричного відділу шлунка: низька його концентрація спостерігається при пілороспазмі, а висока сприяє розвитку дуоденогастрального рефлюксу [11]. Іншими авторами встановлено, що надлишок NO призводить до ослаблення нижнього стравохідного сфінктера та розвитку рефлюксезофагіту [1].

Таким чином, 3 огляду на багатогранний і неоднозначний характер ефектів NO, він зали- шається предметом для подальшого докладного вивчення й уточнення його патогенетичного значення в розвитку респіраторної патології та гастроентерологічних захворювань, особливо у дітей [4].

Незважаючи на велику кількість експериментальних робіт, роль NO в розвитку запальної патології у терапевтичній і педіатричній клініках залишається до кінця не зрозумілою.

Mema роботи - дослідити рівень NO та його метаболітів у плазмі крові та слизовій стравоходу у дітей із частими респіраторними захворюваннями (ЧРЗ) на тлі ГЕРХ.

\section{Матеріал і методи дослідження}

Для реалізації мети та завдання дослідження було обстежено 150 дітей пубертатного віку

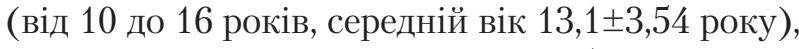
що спостерігалися на клінічній базі кафедри педіатрії №1 «Центр первинної медико-санітарної допомоги №4» Деснянського району м. Києва. Усі підлітки мали ЧРЗ (6-8 разів на рік, тривалістю від 8 до 18 днів, у середньому 12,8 $\pm 5,41$ дня).

Серед обстежених було виділено три групи спостереження: діти з ЧРЗ на тлі ГЕРХ II ступеня (90 дітей, група 1), діти з ЧРЗ без ГЕРХ (30 дітей, група 2), а також група здорових дітей (30 дітей, група 3). Верифікація ГЕРХ проводилась відповідно до протоколу «Уніфікований клінічний протокол первинної, вторинної (спеціалізованої) медичної допомоги. Гастроезофагальна рефлюксна хвороба» (наказ МО3 України від 31.10.2013 р. №943) та за IV Римськими критеріями [9]. Групи були порівнянними за віковим та гендерним розподілом.

Рівень сумарного вмісту метаболітів NO (NO сумарний) у плазмі крові та тканині стравоходу визначали фотометричним методом за допомогою напівавтоматичного аналізатора СФ-2000 (довжина хвилі - 540 нм) з використанням реактиву Грісса. Метод засновано на реакції деазотування сульфанілової кислоти 


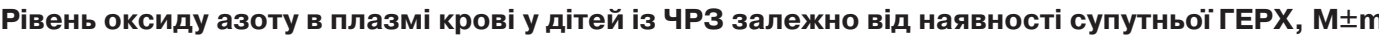

Таблиия 1

\begin{tabular}{|l|c|c|c|}
\hline \multicolumn{1}{|c|}{ Вміст метаболітів монооксиду нітрогену, мкмоль/л } & Група 1 (n=90) & Група 2 (n=30) & Група 3 (n=30) \\
\hline $\mathrm{NO}_{2}$ & $33,4 \pm 2,19^{* *}$ & $30,1 \pm 2,11$ & $26,2 \pm 1,27$ \\
\hline $\mathrm{NO}_{3}$ & $49,5 \pm 3,15^{* *}$ & $42,6 \pm 1,83^{*}$ & $35,3 \pm 2,11$ \\
\hline $\mathrm{NO}$ сумарний & $79,7 \pm 1,28^{* *}$ & $75,9 \pm 3,41^{*}$ & $61,5 \pm 1,54$ \\
\hline
\end{tabular}

Примітка:* достовірність різниці між групою 3 та групою 2 ( $<0,05$ за NO3; p<0,01 за $\mathrm{NO}_{\text {заг.); }}$ ** достовірність різниці між групою 1 та групою 2 ( $<<0,01$ за $\mathrm{NO}$ та $\mathrm{NO}_{3 а г . ; ~}<<0,05$ за $\left.\mathrm{NO}_{2}\right)$.

Таблиия 2

Рівень оксиду азоту в слизовій стравоходу дітей з ЧРЗ залежно від наявності супутньої ГЕРХ

\begin{tabular}{|l|c|c|c|}
\hline \multicolumn{1}{|c|}{ Вміст метаболітів монооксиду нітрогену, мкмоль/л } & Група 1 (n=90) & Група 2 (n=12) & Група 3 (n=10) \\
\hline $\mathrm{NO}_{2}$ & $75,5 \pm 5,54^{\star *}$ & $46,3 \pm 7,36$ & $47,5 \pm 5,46$ \\
\hline $\mathrm{NO}_{3}$ & $144,3 \pm 5,68^{\star \star}$ & $63,8 \pm 5,61$ & $54,3 \pm 5,59$ \\
\hline $\mathrm{NO}$ сумарний & $219,8 \pm 7,69^{\star *}$ & $111,1 \pm 10,6$ & $101,8 \pm 8,63$ \\
\hline
\end{tabular}

Примітка:** достовірність різниці між групою 1 та групою 2 ( $<<0,01$ за NO2, NO3 та $\mathrm{NO}$ сумарний).

3 наявними у пробі нітратами та реакції отримання солі із альфа-нафтиламіном з утворенням червоно-фіолетового або рожевого забарвлення. Інтенсивність забарвлення пропорційна концентрації нітратів [3]. Для визначення нітритів використовували діазотування на основі реакції Грісса. Нітрати відновлювали до нітритів з подальшим діазотуванням. Таким чином, отримували сумарне значення нітриту азоту $\left(\mathrm{NO}_{2}\right)$ і нітрату азоту (NO3) у пробі. Нітрити визначали спектрофотометрично.

Для статистичного аналізу отриманих результатів використовували пакет програм обробки даних загального призначення Statistica for Windows версії 6.0 (Stat Soft inc., США). Нормальність розподілу перевіряли за допомогою тесту Колмогорова-Смірнова. Достовірність різниці визначали за допомогою t-критерію Стьюдента. Для оцінки міри залежності між перемінними використовували кореляційний

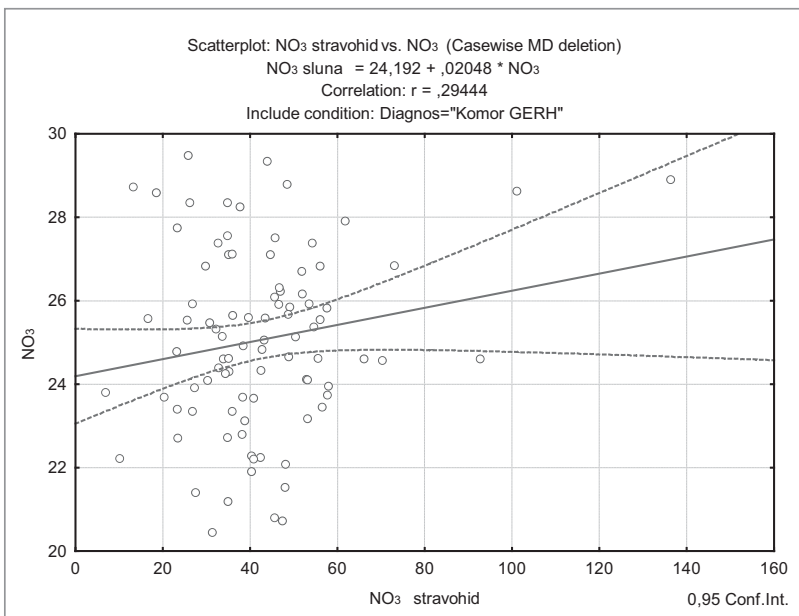

Pис. 1. Кореляційний зв'язок між вмістом метаболіту $\mathrm{NO}_{3}$ у слизовій стравоходу та плазмі крові у дітей з ЧРЗ на тлі ГЕРХ аналіз за Пірсоном. При $\mathrm{p}<0,05$ розбіжності вважали статистично вірогідними.

Дослідження виконані відповідно до принципів Гельсінської Декларації. Протокол дослідження ухвалений Локальним етичним комітетом (ЛЕК) всіх зазначених у роботі установ. На проведення досліджень було отримано поінформовану згоду батьків дітей (або їхніх опікунів).

\section{Результати дослідження та їх обговорення}

Аналіз вмісту NO та його метаболітів у дітей показав його вірогідний приріст у плазмі крові: сумарного NO на 23,4\% у дітей з ЧРЗ та 29,5\% у дітей з ЧРЗ на тлі ГЕРХ, метаболіту $\mathrm{NO}_{2}-$ на $14,9 \%$ та $27,4 \%$, метаболіту $\mathrm{NO}_{3}$ - на $14,9 \%$ та 40,2\% відповідно (табл. 1).

Уміст NO у слизовій стравоходу досліджувався у 90 дітей 1 групи та 12 дітей 2 групи та порівнювався 3 референтними показниками.

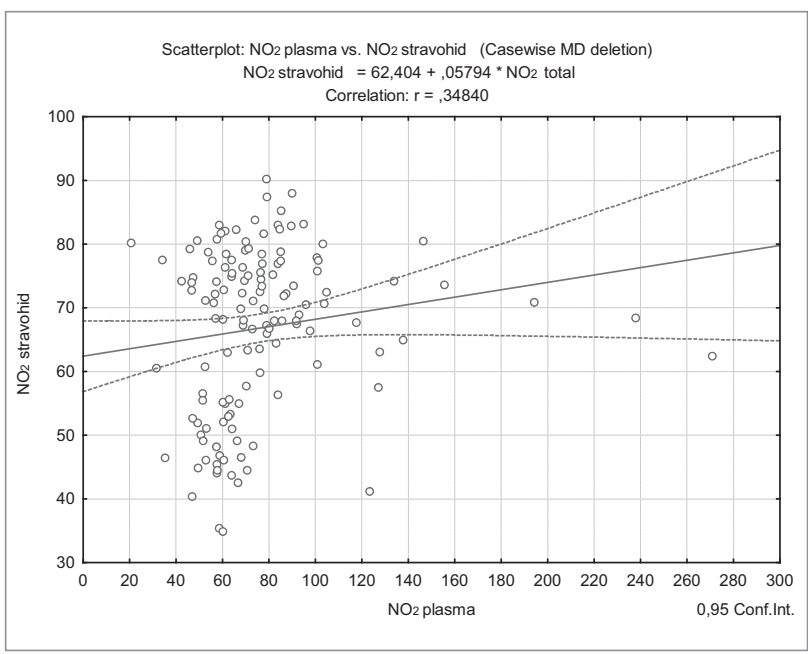

Pис. 2. Кореляційний зв'язок між вмістом метаболіту NO2 у слизовій стравоходу та плазмі крові у дітей з ЧРЗ на тлі ГЕРХ 


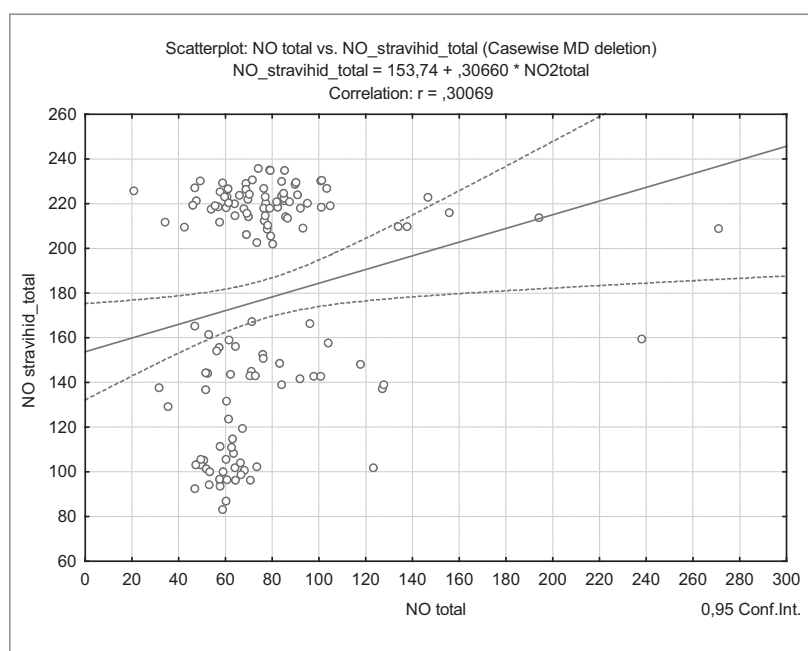

Pис. 3. Кореляційний зв'язок між вмістом метаболіту NO сумарного у слизовій стравоходу та плазмі крові у дітей з ЧРЗ на тлі ГЕРХ

Встановлено суттєвий приріст даного медіатора в слизовій стравоходу дітей з ЧРЗ при супутній ГЕРХ (NO сумарний - у 2,16 разу, $\mathrm{NO}_{3}-$ у 2,1 разу, $\mathrm{NO}_{2}-$ у 1,59 разу), проте в групі дітей із ЧРЗ без ГЕРХ вірогідної різниці щодо групи контролю не виявлено (табл. 2).

У групі дітей з ЧРЗ на тлі ГЕРХ (група 1) проведено лінійний регресійний аналіз та визначено взаємозв'язок між вмістом NO та його метаболітів у плазмі крові і тканині стравоходу. В усіх випадках отримано прямий кореляційний зв'язок середньої сили. Зокрема отримано вірогідний кореляційний зв'язок щодо вмісту метаболіту $\mathrm{NO}_{3}$ слизової стравоходу та плазми крові $\mathrm{r}=0,29(\mathrm{p}<0,05)$ (рис. 1$)$. Відносно метаболіту $\mathrm{NO}_{2}$ слизової стравоходу та плазми крові прямий регресійний зв'язок встановлено на рівні $\mathrm{r}=0,35(\mathrm{p}<0,05)$ (рис. 2). Відносно загального NO слизової стравоходу та плазми крові пряма лінійна регресія становила $\mathrm{r}=0,30$ ( $<<0,05)$ (рис. 3).

Тобто проведені дослідження свідчать, що у дітей з частою респіраторною патологією суттєво змінюється локальна продукція NO, причому наявність супутньої ГЕРХ вірогідно поглиблює цей процес. Збільшення секреції NO у дітей з ЧРЗ на тлі ГЕРХ має важливе значення у патогенезі патологічних процесів слизової стравоходу, а також у підтримці запалення верхніх дихальних шляхів. Встановлені закономірності змін продукції оксиду азоту та цитокінів можуть використовуватися для розробки показань до лікування та оцінки ефективності лікування ГЕРХ та респіраторної патології у дітей.

\section{Висновки}

1. У дітей з ЧРЗ на тлі ГЕРХ встановлено вірогідний приріст NO у плазмі крові.

2. Стосовно аналізу вмісту NO у слизовій стравоходу встановлено суттєвий приріст медіатора при супутній ГЕРХ, проте в групі дітей з ЧРЗ без супутньої ГЕРХ вірогідної різниці щодо групи контролю не встановлено.

3. При оцінці лінійного регресійного зв'язку між вмістом NO та його метаболітів у плазмі крові та тканині стравоходу в усіх випадках було отримано позитивний кореляційний зв'язок - відносно загального NO, а також його метаболітів $\mathrm{NO}_{2}$ та $\mathrm{NO}_{3}$.

Автори заявляють про відсутність конфлікmу інтересів.

\section{ЛITEPATУPA}

1. Kireeva KV, Kankova NYu, Shabunina El et al. (2015). Changes in the Content of Nitric Oxide Derivatives in Children with Inflammatory Diseases of the Esophagus and the Stomach. Medical Almanac. Pediatrics. 4 (39):118-121.

2. Kirnus NI, Artamonov RG, Smirnov IE. (2007). Nitric Oxide and Chronic Diseases of the Digestive Tract in Children. Pediatrics. 86 (5):113-116.

3. Metelskaya VA, Gumanova NG. (2005). Screening Method for Determining the Level of Nitric Oxide Metabolites in Blood Serum. Clinical Laboratory Diagnostics. 6:15-18.

4. Somova LM, Plekhova NG. (2006). Nitric Oxide as a Mediator of Inflammation. Bulletin of the Far East Branch of the Russian Academy of Sciences. 2:77-80.

5. Cirino G, Distrutti E, Wallace JL. (2006). Nitric oxide and inflammation. Inflammation \& Allergy-Drug Targets (Formerly Current Drug TargetsInflammation \& Allergy). 5(2):115-119.

6. Kuiken SD, Tytgat GN, Boeckxstaens GE. (2002). Role of endogenous nitric oxide in regulating antropyloroduodenal motility

in humans. The American journal of gastroenterology. 97(7):166-1667.

7. Lane C, Knight D, Burgess S. et al. (2004). Epithelial inducible nitric oxide synthase activity is the major determinant of nitric oxide concentration in exhaled breath. Thorax. 59(9):757-760.

8. Lok HC, Sahni S, Jansson PJ. et al. (2016). A nitric oxide storage and transport system that protects activated macrophages from endogenous nitric oxide cytotoxicity. Journal of Biological Chemistry. 291(53):27042-27061.

9. Schmulson M. (2018). How to use Rome IV criteria in the evaluation of esophageal disorders. Current opinion in gastroenterology. 34(4):258-265.

10. Shah V, Lyford G, Gores G, Farrugia G. (2004). Nitric oxide in gastrointestinal health and disease. Gastroenterology. 126(3):903-913.

11. Sivarao DV, Mashimo H, Goyal RK. (2008). Pyloric sphincter dysfunction in nNOS?/? and W/Wv mutant mice: animal models of gastroparesis and duodenogastric reflux. Gastroenterology. 135(4):1258-1266.

\section{Сведения об авторах:}

Починок Татьяна Викторовна - д.мед.Н., проф. каф. педиатрии №1 НМУ имени А.А. Богомольца. Адрес: г. Киев, ул. Н. Коцюбинського, 8-А; тел. (044) 465-17-89 Журавель Елена Валентиновна - аспирант каф. педиатрии №1 НМУ имени А.А. Богомольца. Адрес: г. Киев, ул. Н. Коцюбинського, 8-А; тел. (044) 465-17-89. Чернов Александр Владимирович - м.н.с. лаборатории иммунологии ГУ «ИПАГ имени академика Е.М. Лукьяновой НАМН Украины».

Адрес: г. Киев, ул. Платона Майбороды, 8; тел. (044) 484-18-71.

Статья поступила в редакцию 14.11.2018 г.; принята в печать 04.03.2019 г. 


\title{
Н.А. Спринчук,, О.Я. Самсон ${ }^{1,2}$, О.В. Большова ${ }^{1}$ \\ Роль тесту на генерацію інсуліноподібного фактору росту-1 у діагностиці та прогнозі лікування дітей зі збереженою соматотропною функцією
}

'ДУ «Інститут ендокринології та обміну речовин імені В.П. Комісаренка НАМН України», м. Київ Національна медична академія післядипломної освіти імені П.Л. Шупика, м. Київ, Україна

SOVREMENNAYA PEDIATRIYA.2019.2(98):35-40; doi 10.15574/SP.2019.98.35

\begin{abstract}
Мета: оцінити роль тесту на генерацію інсуліноподібного фактору росту-1 (ІФР-1) до гормону росту (ГР) у дифреренціальній діагностиці та прогнозі патогенетичного лікування низькорослості зі збереженою соматотропною функцією.

Матеріали і методи. Групу обстежених склали 55 дітей віком від 5 до 16 років із низькорослістю зі збереженою соматотропною функцією. Визначали цільовий (ЦЗ) та прогнозований зріст (ПЗ). Проводили тест на генерацію ІФР-1 до ГР, який складався з двох етапів. Перший етап включав пробу на чутливість до ГР з розрахунку 0,033 мкГ/кг/добу підшкірно протягом 4-х днів. За відсутності збільшення ІФР-1 у понад два рази через 7 днів пробу продовжували (другий етап): призначали ГР у дозі 0,05 мг/кг протягом 4-х днів з наступним визначенням ІФР-1.

Результати. При формуванні групи дослідження для проведення тесту на генерацію ІФР-1 до ГР включали дітей, у яких ПЗ був нижчим за ЦЗ. Серед 55 пацієнтів із низькорослістю було відібрано 23 хворих, у яких ІФР-1 знаходився нижче ресрерентних значень і склав 106,25 13,8 нг/мл, іншим було виставлено діагноз ідіопатичної низькорослості (IH). При проведенні першого етапу тесту зростання вмісту ІФР-1 у два та більше разів відмічалося у 7 хворих (група I). Збільшення ІФР-1 від 1,5 до 2 разів зареєстровано в 11 хворих (група II). П'ятеро дітей (група ІІІ) мали найгірші показники, вміст ІФР-1 після проби був з незначним підйомом і залишився практично незмінним. Пацієнтам II та III груп провели другий етап тесту. Підвищення IФP-1 у 1,5 та більше разів зареєстровано у 11 хворих. У трьох дітей рівень ІФР-1 на стимуляції мав підйом трохи більше ніж 1, у них відзначено дуже низьку чутливість до ГР. За результатами дослідження соматотропної функції та 2-етапного тесту на генерацію ІФР-1 до ГР у 43 із 55 дітей з низькорослістю без порушення фуннції СТГ був встановлений діагноз IH з призначенням рГР у дозі 0,05 мг/кг на добу; синдром БНГР доведено у 7 хворих із застосуванням рГР у початковій дозі 0,035 мг/кг на добу; синдром РНГР визначений у 5 дітей, яким було рекомендовано лікування препаратами соматомедину. На основі тесту на генерацію ІФР-1 до ГР розроблено алгоритм диференціальної діагностики низькорослості за умов збереженої соматотропної функції.

Висновки. Проба на генерацію ІФР-1 $€$ ефективним критерієм для диференціальної діагностики синдрому БНГР, РНГР та ІН. Дана проба є високопрогностичною для застосування різних доз препаратів рГР у хворих зі збереженою соматотропною функцією.

Ключові слова: діти, тест на генерацію, інсуліноподібний фактор росту-1, біологічно неактивний гормон росту, рецепторна нечутливість, ідіопатична низькорослість.
\end{abstract}

\section{The role of insulin-like growth factor-1 generation test in diagnosis and prognosis of treatment for children with a preserved somatotropic function N.A. Sprinchuk ${ }^{12}$, O.Ya. Samson ${ }^{12}$, O.V. Bolshova}

'State Institution «V.P. Komisarenko Institute of Endocrinology and Metabolism NAMS of Ukraine», Kyiv

${ }^{2}$ Shupyk National Medical Academy of Postgraduate Education, Kyiv, Ukraine

Aim. To evaluate a role of the insulin-like growth factor-1 generation test for growth hormone in differential diagnosis and prognosis of pathogenetic treatment for the short stature with preserved somatotropic function.

Materials and methods. The group of examination included 55 children with short stature and preserved somatotropic function. The patients were aged between 5 and 16 years. Child's target growth (TG) and predicted growth (PG) were determined. The insulin-like growth factor- 1 generation test for growth hormone consisting of two stages was conducted. Stage 1 included a sensitivity test for GH at a rate of $0.033 \mu \mathrm{g} / \mathrm{kg} /$ day, subcutaneously, for 4 days. In the absence of an increase in IGF-1 more than 2-fold, the trial was continued after 7 days (stage two): GH was administered at a dose of 0.05 mg / kg for 4 days, followed by the IGF-1 definition.

Results. Children with PG lower than TG were included into the groups for performing the insulin-like growth factor-1 generation test to growth hormone. Among 55 patients with short stature there were selected 23 patients with IGF- 1 below the reference values, which amounted to $106.25 \pm 13.8 \mathrm{ng} / \mathrm{ml}$, while others were diagnosed with idiopathic short stature (ISS). During stage 1 of test, the growth of IGF-1 content in 2 or more times was noted in 7 patients (Group I). The increase in IGF-1 from 1.5 to 2 times was recorded in 11 patients (group II). The worst indices were observed in five children (Group III), the IGF-1 content after the test was slightly increased and remained practically unchanged. Stage 2 of test was performed in patients of groups II and III. Increased IGF-1 in 1.5 and more times was obtained in 11 patients. In three children, the level of IGF-1 on stimulation had a rise more than 1 , they showed a very low sensitivity to GH. Thus, due to the study of somatotropic function and the 2-stage IGF-1 generation test for growth hormone ISS was diagnosed in 43 of 55 children with the short stature without disorders of the STH function with the administration of rGH at a dose of $0.05 \mathrm{mg} / \mathrm{kg} / \mathrm{day}$, BIGH syndrome has been proved in 7 patients with rGH use in the initial dose of $0.035 \mathrm{mg} / \mathrm{kg} /$ day, RIGH syndrome was defined in 5 children who were recommended to treat with somatomedin drugs. On the basis of IGF-1 generation test for GH, an algorithm for differential diagnostics of the short stature under preserved somatotropic function was developed.

Conclusions. Insulin-like growth factor-1 generation test is an effective criterion for differential diagnosis of biologically inactive growth hormone syndrome, receptor insensitivity to growth hormone and idiopathic short stature. This test is highly prognostic for the application of different doses of recombinant growth hormone in patients with preserved somatotropic function.

Key words: children, generation test, insulin-like growth factor-1, biologically inactive growth hormone, receptor insensitivity, idiopathic short stature. 
Роль теста на генерацию инсулиноподобного фактора роста-1 при диагностике и прогнозе лечения детей с сохраненной соматотропной функцией

Н.А. Спринчук'12, О.Я. Самсон ${ }^{12}$, Е.В. Большова'

'ДУ «Институт эндокринологии и обмена веществ имени В.П. Комиссаренко НАМН Украины», г. Киев

${ }^{2}$ Национальна медицинская академия последипломного образования имени П.Л. Шупика, Киев

Цель: оценить роль теста на генерацию инсулиноподобного фактора роста-1 (ИФР-1) к гормону роста (ГР) при диффференциальной диагностике и прогнозе патогенетического лечения низкорослости с сохраненной соматотропной функцией.

Материалы и методы. Группу обследованных составили 55 детей в возрасте от 5 до 16 лет с низкорослостью и сохраненной соматотропной функцией. Определяли целевой рост (ЦР) и прогнозируемый рост (ПР). Проводили тест на генерацию ИФР-1 к гормону роста (ГР), который состоял из двух этапов. Первый этап включал пробу на чувствительность к ГР из расчета 0,033 мкг/кг/сутки подкожно в течение 4-х дней. При отсутствии увеличения ИФР-1 более чем в два раза, через 7 дней пробу продолжали (второй этап): назначали ГР в дозе 0,05 мг/кг в течение 4-х дней с последующим определением ИФР-1.

Результаты. При формировании группы исследования для проведения теста на генерацию ИФР-1 к ГР включали детей, у которых ПР был ниже ЦР. Среди 55 пациентов с низкорослостью было отобрано 23 больных, у которых ИФР-1 находился ниже ресрерентных значений и составил 106,25ะ13,8 нг/мл, другим был выставлен диагноз идиопатической низкорослости (ИН). При проведении первого этапа теста рост содержания ИФР-1 в два и более раз отмечали у 7 больных (группа I). Увеличение ИФР-1 от 1,5 до 2 раз зафиксировано у 11 больных (группа II). Пятеро детей (группа III) имели худшие показатели, содержание ИФР-1 после пробы было с незначительным подъемом и оставалось практически неизмененным. Пациентам II и III групп провели второй этап теста. Повышение ИФР-1 в 1,5 и более раз было зарегистрировано в 11 больных. У трех детей уровень ИФР-1 на стимуляции имел подъем чуть больше 1, у них отмечена очень низкая чувствительность к ГР. По результатам исследования соматотропной фрункции и двухэтапного теста на генерацию ИФР-1 к ГР у 43 из 55 детей с низкорослостью без нарушения функции СТГ был установлен диагноз ИН с назначением рГР в дозе 0,05 мг/кг в сутки, синдром БНГР доказан у 7 больных с применением рГР в начальной дозе 0,035 мг/кг/сутки, синдром РНГР определен у 5 детей, которым было рекомендовано лечение препаратами соматомедина. На основе теста на генерацию ИФР-1 к ГР разработан алгоритм дифференциальной диагностики низкорослости в условиях сохраненной соматотропной функции.

Выводы. Проба на генерацию ИФР-1 является эффрективным критерием для дифференциальной диагностики синдрома БНГР, РНГР и ИН. Данная проба является высокопрогностической для применения различных доз препаратов рГР у больных с сохраненной соматотропной функцией.

Ключевые слова: дети, тест на генерацию, инсулиноподобный фактор роста-1, биологически неактивный гормон роста, рецепторная нечувствительность, идиопатическая низкорослость.

\section{Вступ}

Ч изькорослість зі збереженою соматотропною функцією гіпофіза донедавна асоціювалася $з$ ідіопатичною низькорослістю (IH). Обов'язковою умовою для діагностики цього стану є нормальний вміст соматотропного гормону (СТГ) у крові хворого, задовільний викид СТГ на тлі стимуляційних тестів при задовільному рівні інсуліноподібного фактору росту-1 (ІФР-1) у плазмі, нормальні довжина та маса тіла при народженні [7]. Але такі самі та схожі на них клінічні і лабораторні критерії синдрому біологічно неактивного гормону росту (БНГР) та синдрому рецепторної нечутливості до гормону росту (РНГР) [10,12]. Донедавна пацієнтам із синдромом БНГР та синдромом РНГР помилково виставляли діагноз IН.

За допомогою медико-генетичних досліджень диференціювати ці нозології нескладно, але це майже недоступно більшості пацієнтів внаслідок обмеженого застосування цих методик в Україні.

Відомо, що всі три патології, а саме синдром БНГР, синдром РНГР та IH, мають різну чутливість до рекомбінантного гормону росту (рГР). 3 цього приводу ми вирішили використати тест на генерацію ІФР-1 до гормону росту (ГР), який вперше був запропонований для постановки діагнозу «Синдром резистент- ності до гормону росту». Цей тест проводять, якщо викид ГР на стимуляцію вищий за 10 нг/мл. Тест полягає в оцінці відповіді ІФР-1 на екзогенний ГР, що вводиться $[8,13]$ : при резистентності до ГР рівень ІФР-1 не змінюється або підвищується не вище ніж на 40 нг/мл від початкового. Найпоширенішими тестами вважаються 4-денні і 7-денні тести [5,6,11]. Проведення цих тестів дає можливість оцінити ступінь нечутливості до ГР (повна чи часткова) $[4,9,15]$.

Теоретично тест на генерацію дозволяє відрізнити резистентність до ГР від БНГР. У першому випадку рівень ІФР-1 суттєво не змінюється, у другому - значно підвищується. Проте на практиці точних критеріїв інтерпретації результатів тесту не існує, що і слугувало підставою для проведення даного дослідження.

Mema дослідження: оцінити роль тесту на генерацію ІФР-1 до ГР у диференціальній діагностиці та прогнозі патогенетичного лікування низькорослості зі збереженою соматотропною функцією.

\section{Матеріал і методи дослідження}

Групу обстежених склали 55 дітей із низькорослістю зі збереженою соматотропною функцією. Вік хворих становив від 5 до 16 років. 
Усі процедури, проведені в дослідженнях із залученням пацієнтів, відповідали етичним стандартам установ 3 клінічної практики та положенням Гельсінської декларації 1964 року, з поправками. Протокол дослідження погоджений Локальним етичним комітетом для всіх, хто брав участь. Пацієнти та їхні батьки або юридичні опікуни пацієнтів підписали форми інформованої згоди, у яких вони погодилися на всі необхідні діагностичні процедури та лікування.

У план обов'язкового обстеження хворого входив загальний огляд, вимірювання росту, вимірювання маси тіла (МТ) та визначення індексу маси тіла (IMT), стандартного відхилення (Standart Deviation, SD) для росту [2], швидкості росту (ШР). Для дослідження впливу існуючої затримки росту хворого на кінцевий зріст (КЗ) проводили розрахунки цільового (ЦЗ) та прогнозованого зросту (ПЗ). Цільовий зріст розраховували за формулами:

- для хлопчиків: (ріст батька + ріст матері + 13)/2 (см);

- для дівчаток: (ріст батька + ріст матері13)/2 (см).

Прогнозований зріст визначався за формулою В. Блунка (1981) з використанням таблиць, де враховувався реальний зріст та кістковий вік (КВ) пацієнта на момент його обстеження [1]. Кістковий вік хворих визначався 3 використанням атласу W.W. Greulich та S. P. Pyle (1993).

Для вивчення соматотропної, тиреотропної та адренокортикотропної функцій досліджували рівні СТГ, ІФР-1, тиреотропного гормону, тироксину вільного, трийодтироніну вільного та кортизолу крові радіоімунологічним методом за допомогою стандартних наборів IRMA (Immunotech, Чехія).

Тест на генерацію до ГР складався 3 двох етапів. На першому етапі тест включає пробу на чутливість до ГР: під час тесту призначали препарати рГР у дозі 0,033 мкг/кг підшкірно один раз на добу протягом чотирьох днів. За відсутності збільшення IФР-1 у понад два рази через сім днів пробу продовжували (другий етап): призначали рГР у дозі 0,05 мг/кг протягом чотирьох днів з наступним визначенням рівня ІФР-1. Тест проводили хворим зі збереженою соматотропною функцією та незадовільним прогнозом росту. Цей тест також використовували для прогнозу ефективності лікування рГР. Підвищення рівня ІФР-1 після застосування рГР у дозі 0,05 мг/кг/добу більше ніж у 1,5-2 рази розцінювали як позитивний тест, менше ніж у 1,5 - як негативний.

Контрольну групу склали 10 здорових дітей відповідного віку.

Результати надано у вигляді середніх значень та їх стандартної похибки $(\mathrm{M} \pm \mathrm{m})$. Статистичну достовірність оцінювали за параметричним критерієм Стьюдента (t). Різниця в результатах вважалась вірогідною при $\mathrm{p}<0,05$; при $0,05<\mathrm{p}<0,1$ відмічали тенденцію до вірогідності.

\section{Результати дослідження та їх обговорення}

Пацієнти мали нормальну масу та довжину тіла при народженні. Хромосомні та важкі соматичні захворювання у них були відсутні. Сімейний анамнез без випадків низькорослості був у 21 пацієнта, у 34 хворих родичі першого та другого ступеня спорідненості мали низький зріст, тобто у $61,8 \%$ хворих була обтяжена спадковість.

Хворі звернулися зі скаргами на недостатній ріст та незадовільну ШР протягом останніх років, яка становила від 1 до 4 см на рік. Відставання у рості стало помітним у період від 3 до 8 років після народження. Специфічної гормональної ростстимулюючої терапії пацієнти не отримували.

Усі хворі мали правильну будову тіла. При огляді дітей з боку внутрішніх органів додаткової супутньої патології не виявлено. Затримка росту у хворих на момент обстеження була від $-2,0$ SD до - 3 SD. Затримка у масі тіла була пропорційною затримці у рості, IMT становив від 19,5 до 21 кг/м², що було більше від 50 перцентилю для відповідного віку та статі.

Обов'язково у всіх обстежених дітей оцінювали КВ, який є необхідним для розрахунку ПЗ. У 29 дітей відставання КВ порівняно з паспортним становило від 2 до 3 років, у 7 пацієнтів - від 4 до 7 років. У 19 дітей рентген-вік збігався з біологічним або відставав від 6 місяців до 1,5 року, до цієї категорії відносили дітей 3 початковим або активним статевим розвитком.

При формуванні групи дослідження для проведення тесту на генерацію ІФР-1 до ГР включали дітей, у яких ПЗ був значно нижче ЦЗ. Розрахунок середнього ЦЗ (очікуваного) та ПЗ у хлопців визначив значний розрив між цими показниками $(\mathrm{p}<0,05)$, які були $176,05 \pm 0,98$ та $164,86 \pm 3,56$ (см) відповідно у хлопців без обтяженої спадковості і $168,29 \pm 1,29$ та $157,25 \pm 1,72$ (см) у хлопців 3 


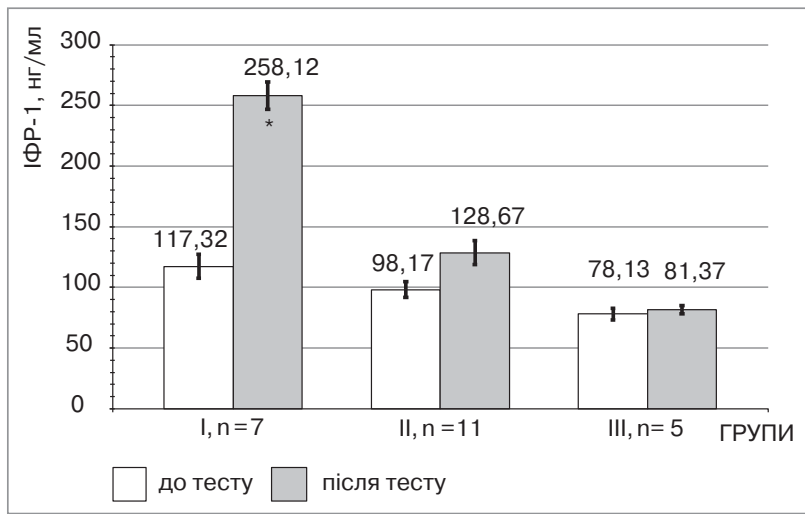

Примітка: *- p<0,01достовірністьзмін ІФР-1 до та після проби. Pис. 1. Показники ІФР-1 (нг/мл) у дітей 3 низькорослістю у процесі проведення першого етапу тесту (стимуляція рГР

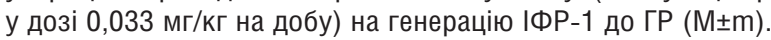

обтяженою спадковістю. У дівчат обох груп ці показники не мали достовірних відмінностей. Дівчата з обтяженою спадковістю мали не тільки найгірший прогноз КЗ серед усіх обстежених дітей, що визначався на підставі ПЗ і відповідав значенню $152,78 \pm 2,85$ см, але й найнижчий ЦЗ,

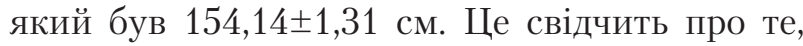
що 3 найбільшою вірогідністю, ці пацієнти мали хромосомно-генетичні фактори низькорослості. У дівчат без обтяженої спадковості показники ЦЗ і ПЗ між собою відрізнялися, але без достовірної різниці, та відповідали значенням165,19 $\pm 7,91$ і $158,12 \pm 8,84$ (см).
Усім хворим для оцінки соматотропної функції визначали вміст СТГ, ІФР-1, проводили фармакологічні стимуляційні тести 3 клонідином та інсуліном.

При визначенні вмісту СТГ у крові обстежених хворих отримано результати, які підтверджують відсутність порушення соматотропної функції у дітей з низькорослістю. Встановлено, що базальний рівень ГР у хворих та здорових дітей достовірно не відрізнявся і становив відповідно $1,7 \pm 0,45$ та $0,85 \pm 0,19$ нг/мл.

Нічний пік СТГ на 120 хвилині після засинання у здорових дітей достовірно відрізнявся від дітей з низькорослістю і відповідав показ-

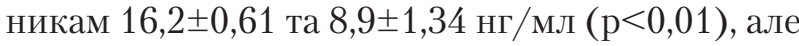
він однаково відносився до нормальних значень для збереженої секреції СТГ. Максимальний викид СТГ на стимуляцію клонідином був достовірно нижчим у хворих на низькорослість порівняно зі здоровими дітьми, проте він був вищим за діагностичну межу норми 10 нг/мл, а саме у хворих з низькорослістю відповідав $13,11 \pm 1,21$ нг/мл, а у здорових дітей дорівнював 20,9 $\pm 1,4$ нг $/$ мл $(\mathrm{p}<0,01)$.

При дослідженні ІФР-1 у плазмі крові хворих на низькорослість встановлено, що він був меншим референтних показників або коливався від нижньої межі норми до середніх значень і в цілому по групі склав 198,01 23,12 нг/мл 3 відставанням на -1,34 SD. Якщо проаналізува-

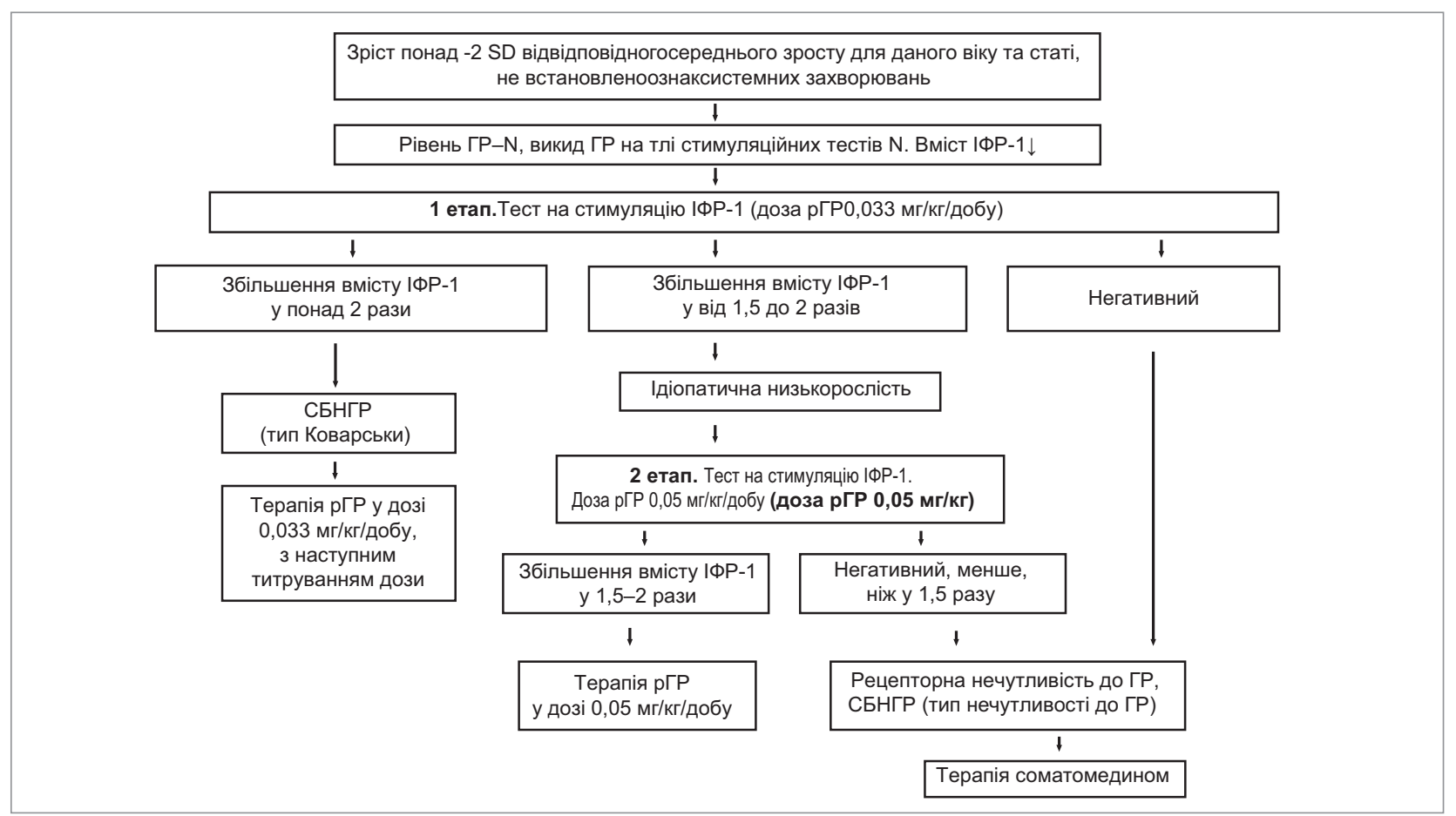

Pис. 2. Алгоритм діагностики та прогнозування ефективності лікування хворих на низькорослість зі збереженою соматотропною функцією гіпофріза 
ти індивідуально, у 32 пацієнтів рівні ІФР-1 були вищими за нижню межу норми. Згідно 3 міжнародним консенсусом 3 діагностики та тактики ведення пацієнтів 3 IH, цим дітям був встановлений діагноз ідіопатичної низькорослості. Потреби у проведенні проби на чутливість до ГР у цих дітей не було, їм призначили лікування рГР у дозі 0,05 мг/кг на добу [7].

Іншим хворим планувалося проведення тесту на генерацію ІФР-1 до ГР, який складався з двох етапів у тих пацієнтів, що мали знижені показники IФР-1. Проведення цього тесту рекомендовано хворим з підозрою на синдром БНГР, синдром РНГР та IH зі зниженими показниками ІФР-1 для проведення їх диференціальної діагностики та оцінки прогнозу лікування рГР.

На першому етапі тесту проводилась чотириденна проба на чутливість до ГР. У пацієнтів із синдромом БНГР при проведенні проби спостерігається максимальний викид IФР-1 ще на першому етапі, на відміну від хворих $3 \mathrm{IH}$, РНГР та з рідкісною гормононечутливою формою синдрому БНГР (мутація R77C та їй подібні).

У тих пацієнтів, у кого було відсутнє збільшення ІФР-1 у два і більше разів, через сім днів тест продовжували: призначали рГР у дозі 0,05 мг/кг протягом чотирьох днів 3 наступним визначенням рівня IФР-1. Цей тест використовували не тільки для диференціальної діагностики різних форм низькорослості зі збереженою функцією СТГ, але й для оцінки адекватності відповіді організму на стимуляцію різних доз рГР для прогнозу ефективності його застосування у лікуванні різних форм низькорослості. Збільшення рівня ІФР-1 після призначення рГР у дозі 0,05 мг/кг/добу у понад 1,5-2 рази розцінювали як позитивний другий етап тесту, менше ніж у 1,5 - як негативний.

Серед 55 пацієнтів з низькорослістю було відібрано 23 хворих з показником ІФР-1 нижче референтних значень $-106,25 \pm 13,8$ нг/мл. Їм проводили перший етап тесту на стимуляцію ІФР-1. При проведенні тесту зростання вмісту ІФР-1 у два та більше разів відмічалося у сімох хворих (група I) з показниками IФP-1 до та після стимуляції рГР відповідно $117,62 \pm 9,7$ нг/мл та 258,12 $\pm 11,4$ нг/мл, що свідчило на користь синдрому БНГР у цих дітей. Збільшення ІФР-1 до від 1,5 до 2 разів зафіксовано у 11 хворих (група II) 3 відповідними

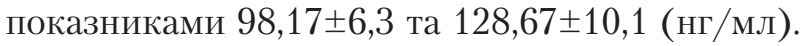

П'ятеро дітей (група III) мали найгірші показники, вміст ІФР-1 після проби був з незначним підйомом і залишився практично не зміненим у трьох пацієнтів. У двох з п'яти дітей показник ІФР-1 мав менші значення, ніж до проведення стимуляції рГР, при цьому показники ІФР-1 у цілому по групі до та після проби були $78,13 \pm 4,9$ нг/мл та $81,37 \pm 3,4$ нг/мл відповідно (рис.1).

Цей факт свідчить на користь втрати рецепторної чутливості до ГР (синдром Ларона) або про наявність у даних пацієнтів гормононечутливої форми синдрому БНГР. Цим хворим у лікуванні рекомендовано віддавати перевагу препаратам соматомедину. Усім пацієнтам II групи та трьом дітям 3 незначним збільшенням IФP-1 III групи (усього 14 дітей) пропоновано провести другий етап тесту.

Наприкінці другого етапу тесту отримано підвищення ІФР-1 у 1,5 та більше разів у 11 хворих з показниками до та після тесту від-

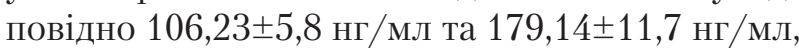
причому це були діти, які на першому етапі тесту склали групу II. Можемо припустити, що це діти з частковою (слабкою) РНГР та з різними формами синдрому БНГР, з мутацією R77C або їй подібними, які мають погану чутливість до стимуляції рГР. Але за лабораторними діагностичними ознаками (згідно 3 міжнародним консенсусом 3 діагностики IH) ми виставили дітям діагноз IН. Таким пацієнтам можна призначати лікування препаратами $\mathrm{p} Г \mathrm{P}$ у дозі 0,05 мг/кг/добу. У трьох дітей з групи III рівень ІФР-1 на другому етапі стимуляції мав підйом трохи більше за 1 і становив до та після тесту $82,43 \pm 3,8$ нг/мл та $102,06 \pm 5,9$ нг/мл відповідно, у цих дітей відзначена дуже низька чутливість до рГР.

Цим пацієнтам виставлений діагноз рецепторної нечутливості до ГР (синдром Ларона), їм застосування рГР не показано. Даній категоpiï дітей рекомендовано призначати препарати рекомбінантного соматомедину. Подібна діагностична ситуація може бути присутньою у дітей з нечутливою формою синдрому БНГР до рГР, яка зустрічається вкрай рідко. Для уточнення діагнозу рекомендовано секвенування гена ГР [3].

За даними літератури, тест на генерацію ІФР-1 до ГР часто застосовують для оцінки сумнівної нечутливості до ГР. R. Coutant і співавт. повідомили про результати опитування серед членів Європейського товариства педіатрів-ендокринологів та надали рекомендації 
щодо застосування тесту в цьому випадку. За даними опитування, чутливість і специфічність тесту становила $77-91 \%$ і $\leq 97 \%$ відповідно [8]. Деякі автори стверджують, що достовірно тест може визначити лише важкі форми нечутливості до ГР (синдром Ларона). При цьому застосовують критерії Blum (1992) або Savage (1993) - відсутність підвищення ІФР-1 менше ніж на 15 нг/мл (або менше, ніж 2 SD) говорить про резистентність. Для інтерпретації серії тестів 3 різними дозами також запропоновано декілька критеріїв - J. Blair (2004), M. Walenkamp (2006) [5,14].

Результати нашої роботи довели, що тест на генерацію ІФР-1 може ефективно використовуватись для діагностики низькорослості зі збереженою соматотропною функцією. Дослідженням СТГ-функції та проведенням двоетапної проби на генерацію ІФР-1 до ГР у 43 із 55 дітей з низькорослістю без порушення функції СТГ був встановлений діагноз IН з призначенням рГР у дозі 0,05 мг/кг на добу; синдром БНГР (тип Коварськи) доведено у сімох хворих із застосуванням рГР у дозі 0,035 мг/кг на добу; синдром РНГР (синдром Ларона) визначений у п'ятьох дітей, яким було рекомендовано лікування препаратами соматомедину.

У відділенні дитячої ендокринної патології ДУ «Інститут ендокринології та обміну речовин імені В.П. Комісаренка» на основі тесту на генерацію IФP-1 розроблений алгоритм диференціальної діагностики різних форм низькорослості за умов збереженої соматотропної функції із рекомендованими патогенетично обгрунтованими дозами застосування рГР (рис. 2).

\section{Висновки}

1. Проба на генерацію ІФР-1 до ГР є ефективним критерієм для диференціальної діагностики між синдромом БНГР, синдромом РНГР та IH.

2. Дана проба є високопрогностичною для застосування препаратів рекомбінантного ГР у хворих зі збереженою соматотропною функцією.

Автори заявляють про відсутність конфлікmy інтересів.

\section{ЛITEPATУРА}

1. Блунк В. (1981). Детская эндокринология. Пер. с нем. Р.М. Пархимовича. Москва: Медицина:303.

2. Протоколи надання медичної допомоги дітям за спеціальністю «Дитяча ендокринологія» (зміни та доповнення) від 03.02.09 №55 (2009). Київ.

3. Спринчук HA, Досенко B€. (2016). Роль визначення мутації D112G в діагностиці хворих на синдром біологічно неактивного росту серед дітей, що проживають на території України. Доповіді Національної академії наук України. 3:107-12.

4. Тронько МД. (ред.) (2010). Довідник лікаря-ендокринолога. 3-є вид., перероб. і доп. Київ: ТОВ Доктор-Медіа:460.

5. Шандин АН, Петеркова ВА. (2009). Классификация, диагностика и лечение идиопатической низкорослости. Пробл эндокринол. 55(4):36-43.

6. Ali A, Hashim R, Khan FA, Sattar A, ljaz A, Manzoor SM Younas M. (2009). Evaluation of insulin-like growth factor-1 and insulinlike growth factor binding protein-3 in diagnosis of growth hormone deficiency in short-stature children. J Ayub Med Coll Abbottabad. 21(3):40-5.

7. Cohen P, Rogol AD, Deal CL, Saenger P, Reiter EO, Ross JL et al. (2008). Consensus statement on the diagnosis and treatment of children with idiopathic short stature: a summary of the Growth Hormone Research Society, the Lawson Wilkins Pediatric Endocrine Society, and the European Society for Paediatric Endocrinology Workshop. J Clin Endocrinol Metab. 93(11):4210-7.
8. Coutant R, D?rr HG, Gleeson H, Argente J. (2012). Diagnosis of endocrine disease: limitations of the IGF1 generation test in children with short stature. Eur J Endocrinol.166(3):351-7.

9. Maghnie M, Labarta JI, Koledova E, Rohrer TR. (2018). Short stature diagnosis and referral. Front Endocrinol (Lausanne).8:374.

10. Moia S, Tessaris D, Einaudi S, deSanctis L, Bona G, Bellone $S$ et al. (2017). Compound heterozygosity for two GHR missense mutations in a patient affected by Laron Syndrome: a case report. Ital J Pediatr. 43(1):94.

11. Rosenfeld RG, Buckway C, Selva K, Pratt KL, Guevara-Aguirre J. (2004). Insulin-like growth factor (IGF) parameters and tools for efficacy: the IGF-I generation test in children. Horm Res. 62;1:37-43.

12. Savage MO, Hwa V, David A, Rosenfeld RG, Metherell LA. (2011). Genetic defects in the growth hormone-IGF-I axis causing growth hormone insensitivity and impaired linear growth. Front Endocrinol (Lausanne).12(2):95.

13. Smyczynska J, Hilczer M, Stawerska R, Lewinski A. (2013). Asignificant increase of IGF-I concentration and of IGF-I/IGFBP-3 molar ratio in generation test predicts the good response to growth hormone (GH) therapy in children with short stature and normal results of GH stimulating tests. Neuro Endocrinol Lett. 34(3):222-8.

14. Walenkamp MJE, Wit JM. (2006). Genetic disorders in the growth hormone - insulin-like growth factor-I axis. Horm Res. 66(5):221-30.

15. Wit JM, Oostdijk W, Losekoot M. (2012). Spectrum of insulin-like growth factor deficiency. Endocr Dev.23:30-41.

\section{Сведения об авторах:}

Спринчук Наталья Андреевна - к.мед.Н., С.н.с., зав. отделения детской эндокринной патологии ГУ «Институт эндокринологии и обмена веществ имени В.П. Комисаренко НАМН Украиныр; доц. каф. эндокринологии НМАПО имени П. Л. Шупика. Адрес: г. Киев, ул. Вышгородская, 69.

Большова Елена Васильевна - д.мед.н., проф., руководитель отдела детской эндокринной патологии ГУ «Институт эндокринологии и обмена веществ имени В.П. Комисаренко НАМН Украины». Адрес: г. Киев, ул. Вышгородская, 69.

Самсон Оксана Ярославовна - к.мед.н., Н.С. отделения детской эндокринной патологии ГУ «Институт эндокринологии и обмена веществ имени В.П. Комисаренко НАМн Украины», преподаватель каф. эндокринологии НМАПО имени П. Л. Шупика. Адрес: г. Киев, ул. Вышгородская, 69.

Статья поступила в редакцию 18.10 .2018 г; принята в печать 26.02.2019 г. 


\section{О.К. Колоскова', О.О. Шахова', С.І. Тарнавська', І.О. Маніліч² Динамічні показники неспецифічної гіперсприйнятливості бронхів у підлітків, хворих на бронхіальну астму}

'ВДНЗУ «Буковинський державний медичний університет», м. Чернівці ${ }^{2} \mathrm{KMУ} \mathrm{«Обласна} \mathrm{дитяча} \mathrm{клінічна} \mathrm{лікарня»,} \mathrm{м.} \mathrm{Чернівці,} \mathrm{Україна}$

SOVREMENNAYA PEDIATRIYA.2019.2(98):41-45; doi 10.15574/SP.2019.98.41

Мета: у міжнападовому періоді бронхіальної астми (БА) оцінити показники неспецифічної реактивності бронхів у дітей підліткового віку за результатами багаторічного динамічного спостереження.

Матеріали і методи. Проведено визначення неспецифічної гіперсприйнятливості бронхів у 42 дітей підліткового віку з БА. Обстеження проводили у міжнападовому періоді, коли у дитини були повністю відсутні клінічні прояви обструкції бронхів і відмінялися медикаменти, які могли вплинути на точність оцінки неспецисічної гіперсприйнятливості до прямих і непрямих стимулів. У більшості дітей обстеження проводилися багаторазово у динаміці спостереження.

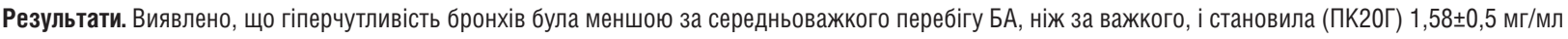

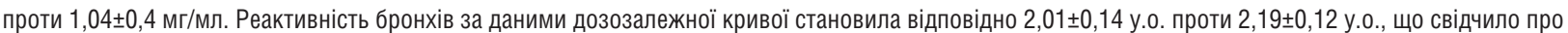
вищий ступінь реактивності дихальних шляхів при важкому перебігу захворювання у підлітків. По мірі посилення важкості захворювання у підлітків зростає лабільність бронхів (ПЛБ). Так, при легкому перебігу захворювання ПЛБ дорівнює 9,26士0,13\% (95\% ДІ: 0,12-1,45), при середньоважкому —

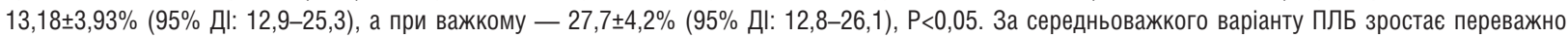

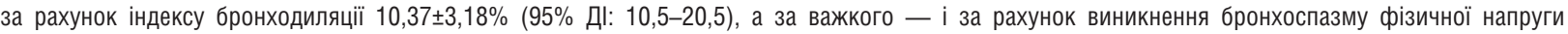
$12,3 \pm 3,34 \%$ (95\% ДI: 9,5-20,4).

Висновки. Гіперсприйнятливість дихальних шляхів до прямих і непрямих стимулів у міжнападовому періоді, мабуть, поєднує спільні механізми, до яких передусім слід віднести запалення дихальних шляхів, а неспецифічну гіперреактивність бронхів у дітей підліткового віку, мабуть, слід розглядати як мультифакторний феномен, а скоріше - епіфеномен БА.

Ключові слова: бронхіальна астма, підлітки, гіперсприйнятливість дихальних шляхів.

\section{Dynamic parameters of nonspecific hypersusceptibility of the bronchi in teenagers with bronchial asthma \\ O.K. Koloskova', O.0. Shakhova', S.I. Tarnavska', I.O. Manilich ${ }^{2}$}

'HSEE «Bukovinian State Medical University», Chernivtsi, Ukraine

${ }^{2}$ Municipal Establishment «Regional Children Clinical Hospital», Chernivtsi, Ukraine

Objective: to assess parameters of nonspecific bronchial reactivity in teenagers during attack-free period of bronchial asthma according to the results of a dynamic observation for many years.

Materials and methods. Nonspecific hypersuscpetibility of the bronchi was determined in 42 teenagers suffering from bronchial asthma (BA). Examinations were conducted in the period between attacks, when clinical signs of bronchial obstruction were completely absent and medicines able to affect the accuracy of nonspecific hypersusceptibility to direct and indirect stimuli were cancelled. The majority of children were repeatedly examined in the dynamics of observation.

Results. Bronchial hypersusceptibility was found to be lower in case of moderate course of bronchial asthma than in case of its severe variant, and constituted (threshold concentration $20 \mathrm{~g}) 1,58 \pm 0,5 \mathrm{mg} / \mathrm{ml}$ against $1,04 \pm 0,4 \mathrm{mg} / \mathrm{ml}$. Bronchial reactivity according to the data of the dose-dependent curve was $2,01 \pm 0,14$ standard units against 2,19 $\pm 0,12$ standard units respectively, which was indicative of a higher degree of the respiratory tract reactivity in case of severe course of the disease among teenagers. As far as severity of the disease among teenagers intensifies, bronchial liability indices (BLIs) increase. Thus, in case of a mild course of the disease $\mathrm{BLI}$ is equal $9,26 \pm 0,13 \%(95 \% \mathrm{Cl}: 0,12-1,45)$, in case of a moderate one $-13,18 \pm 3,93 \%$ (95\% Cl:12,9-25,3), and severe course of $\mathrm{BA}-27,7 \pm 4,2 \%(95 \% \mathrm{Cl}: 12,8-26,1),(\mathrm{P}<0,05)$. With a moderate variant BLI increases mainly at the expense of bronchodilation index $10,37 \pm 3,18 \%$ (95\% Cl:10,5-20,5), with severe variant — at the expense of occurrence of physical strain bronchial spasm 12,3 $\pm 3,34 \%(95 \% \mathrm{Cl}: 9,5-20,4)$. Conclusion. Hypersuscpetibility of the respiratory tract to direct and indirect stimuli during the period between attacks is likely to combine similar mechanisms, first of all including inflammation of the respiratory tract. Moreover, nonspecific bronchial hypersuscpetibility in teenagers should be considered as a multifactorial phenomenon, and rather epiphenomenon of bronchial asthma.

Key words: bronchial asthma, teenagers, hypersuscpetibility of the respiratory tract.

\section{Динамические показатели неспецифической гипервосприимчивости бронхов у подростков, больных бронхиальной астмой Е.К. Колоскова' ${ }^{1}$ О.А. Шахова', С.И. Тарнавская', И.А. Манилич²}

'ВГУЗУ «Буковинский государственный медицинский университет», г. Черновцы

2КМУ «Областная детская клиническая больница», г. Черновцы, Украина

Цель: в межприступном периоде бронхиальной астмы (БА) оценить показатели неспецифической реактивности бронхов у детей подросткового возраста по результатам многолетнего динамического наблюдения.

Пациенты и методы. Проведено обследование неспецифической гипервосприимчивости бронхов у 42 детей подросткового возраста с БА. Обследование проводили в межприступный период, когда у ребенка полностью отсутствовали клинические проявления обструкции бронхов и были отменены медикаменты, которые могли бы повлиять на точность оценки неспецифрической гипервосприимчивости к прямым и непрямым стимулам. У большинства детей обследования проводились многократно в динамике наблюдения.

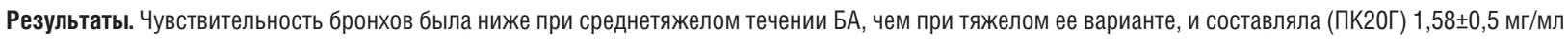

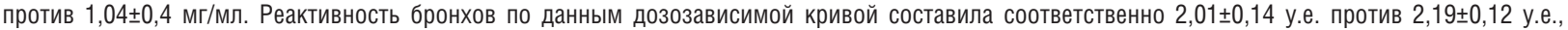


что свидетельствовало о более высокой реактивности дыхательных путей при тяжелом течении заболевания у подростков. По мере усиления тяжести заболевания у подростков возрастала лабильность бронхов (ПЛБ). Так, при легком течении заболевания ПЛБ равен 9,26ะ0,13\% (95\% ДИ:

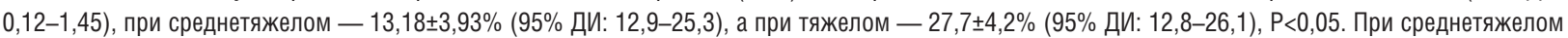
варианте ПЛБ растет в основном за счет индекса бронходилатации 10,37ะ3,18\% (95\% ДИ: 10,5-20,5), а при тяжелом — также и за счет бронхоспазма физического напряжения 12,3 $\pm 3,34 \%$ (95\% ДИ: 9,5-20,4).

Выводы. Гипервосприимчивость дыхательных путей к прямым и непрямым стимулам в межприступном периоде, пожалуй, объединяет общие механизмы, к которым, прежде всего, следует отнести воспаление дыхательных путей, а неспецифическую гиперреактивность бронхов у детей подросткового возраста, видимо, следует рассматривать как мультифакторный феномен, а может быть даже - эпифеномен БА.

Ключевые слова: бронхиальная астма, подростки, гипервосприимчивость дыхательных путей.

\section{Ветуп}

Запалення бронхів, іх гіперсприйнятлиЗ вість і ремоделювання є характерними феноменами чи епіфеноменами бронхіальної астми (БА), які беруть участь у формуванні різних фенотипів даної патології [1,5,9]. Перехід хворих на БА з дитячого віку у підлітковий переважно характеризується полегшенням клінічних проявів захворювання, частими і тривалими ремісіями, переважанням серед хворих представниць жіночої статі, а також скороченням групи пацієнтів із персистувальним перебігом захворювання. Легший та інтермітуючий перебіг астми у підлітків є передумовою для зменшення активності базисної терапії або її повної відміни, що сприяє погіршенню ефективності лікування в даному віці та зменшенню досягнення не лише клінічної, але й спірографічної стійкої ремісії у подальшому [3,6]. Гіперсприйнятливість дихальних шляхів можна розглядати як провідний механізм клінічних проявів БА, що корелюе з важкістю захворювання, хоча може перебігати асимптоматично, проте ії значення як предиктора астми у підлітків залишається недостатньо вивченим [4]. Важливо, що асимптоматична гіперсприйнятливість бронхів супроводжується ознаками запалення дихальних шляхів та персистувальним ремоделюванням [2,8]. Це дає підстави вважати, що наявність гіперсприйнятливості бронхів у підлітків у періоді клінічної ремісії БА слід розглядати як показник персистувального запалення дихальних шляхів та як чинник ризику загострень захворювання, особливо за іiі асоціації $з$ атопією [7].

У періоді клінічної ремісії зазвичай трапляється зниження гіперреактивності бронхів, проте не їх гіперсприйнятливості, що проявляеться збереженням останньої за відсутності чи незначної виразності симптомів захворювання. В останньому випадку знижене іх сприйняття може створити ілюзію ремісії БА. Окрім того, гіперсприйнятливість бронхів - це двокомпонентний феномен, який визначається як генетичними чинниками, так і запаленням [8].
Під впливом базисної терапії зменшуеться чи зникає запалення бронхів, проте залишається генетично детермінована компонента.

3 практичної точки зору надзвичайно важливим $є$ визначення у підлітковому віці неспецифічної гіперсприйнятливості бронхів (НГСБ), як ризику транслокації БА у дорослий період життя, коли формуються хронічні обструктивні захворювання легень.

Mema: у міжнападовому періоді БА оцінити показники НГСБ у дітей підліткового віку з урахуванням результатів багаторічного динамічного спостереження.

\section{Матеріал і методи дослідження}

На базі пульмонологічного відділення ОДКЛ (м. Чернівці) проведене визначення НГСБ у 42 дітей підліткового віку, що хворіють на БА. Обстеження проводили у міжнападовому періоді, за повної відсутності клінічних проявів обструкції бронхів та відміни медикаментів, які могли б уплинути на точність оцінки неспецифічної гіперсприйнятливості до прямих і непрямих стимулів. У більшості дітей обстеження проводили багаторазово в динаміці спостереження. Дослідження, проведене наприкінці спостереження за вказаною когортою дітей, у подальшому визначатиметься за рейтингом як «актуальне», а проведене у попередньому періоді - як «анамнестичне», причому рейтинг «анамнестичне дослідження 1» є найбільш віддаленим у часі від актуального дослідження.

Для оцінки НГСБ у обстежених підлітків вивчали чутливість і реактивність дихальних шляхів до інгаляцій серійно розведеного гістаміну, який можна розглядати як прямий бронхоконстрикторний стимул, а також лабільність бронхів у результаті впливу непрямого бронхоспазмогенного стимулу - дозованого фізичного навантаження, з урахуванням бронхорозширювального ефекту сальбутамолу.

При оцінці гіперсприйнятливості бронхів до гістаміну визначали їх чутливість до даного прямого бронхоконстрикторного стимулу, 
показником якої служили провокаційна концентрація (ПК20Г) та доза (ПД20Г) препарату, що знижували об'єм форсованого видиху за 1 секунду (ОФВ 1 с) на 20\%, а також гіперреактивність, мірою якої була дозозалежна крива (ДЗК), що відображувала швидкість розвитку бронхоспазму. При цьому зниження показників ПК20Г і ПД20Г вказували на посилення ГЧБ, а зростання значень ДЗК - на збільшення їх реактивності.

Дослідження виконані відповідно до принципів Гельсінської Декларації. Протокол дослідження ухвалений Локальним етичним комітетом (ЛЕК) всіх зазначених у роботі установ. На проведення досліджень було отримано поінформовану згоду батьків дітей (або їхніх опікунів).

\section{Результати дослідження та їх обговорення}

$\mathrm{y}$ табл. 1 наведені показники гіперсприйнятливості бронхів до гістаміну у динаміці спостереження.

Отримані дані дають підстави вважати, що в процесі динамічного спостереження гіперчутливість бронхів до гістаміну можна розглядати як стабільнішу середньогрупову величину, а гіперреактивність дихальних шляхів - як таку, що змінюється залежно від ситуації, проте в динаміці спостереження має чітку тенденцію до погіршання.

Оскільки важкий напад БА, згідно 3 міжнародними рекомендаціями, розглядають як маркер щонайменше середньоважкого або важкого перебігу БА, нами вивчено гіперчутливість бронхів до гістаміну за вказаної важкості захворювання у підлітків. Так, за середньоважкої астми гіперчутливість бронхів (ПК20Г) була менш виразною, ніж за важкої, і становила $1,58 \pm 0,5$ мг/мл проти 1,04 $\pm 0,4$ мг/мл. Реактивність бронхів (за даними ДЗК) становила від-

Таблиия 1

Показники гіперчутливості та реактивності бронхів у динаміці спостереження (95\% ДІ)

\begin{tabular}{|c|c|c|c|c|}
\hline \multirow{2}{*}{$\begin{array}{c}\text { Період } \\
\text { спосте- } \\
\text { реження }\end{array}$} & \multirow{2}{*}{$\begin{array}{c}\text { Кількість } \\
\text { дітей }\end{array}$} & \multicolumn{2}{|c|}{ Гіперчутливість бронхів } & \multirow{2}{*}{$\begin{array}{c}\text { Гіперреак- } \\
\text { тивність } \\
\text { бронхів: } \\
\text { дЗК (у.о.) }\end{array}$} \\
\hline & & $\begin{array}{l}\text { ПК20Г } \\
\text { (Мг/мл) }\end{array}$ & $\begin{array}{c}\text { Пд20Г } \\
\text { (мг) }\end{array}$ & \\
\hline Анамнез 1 & 16 & $\begin{array}{l}1,25 \pm 0,36 \\
(0,02-5,1)\end{array}$ & $\begin{array}{c}0,27 \pm 0,08 \\
(0,004-1,12)\end{array}$ & $\begin{array}{l}1,88 \pm 0,20 \\
(0,71-3,2)\end{array}$ \\
\hline Анамнез 2 & 10 & $\begin{array}{l}2,21 \pm 1,10 \\
(0,14-6,7)\end{array}$ & $\begin{array}{c}0,48 \pm 0,24 \\
(0,03-1,51)\end{array}$ & $\begin{array}{c}1,19 \pm 0,21 \\
(0,65-1,88)\end{array}$ \\
\hline AK & 27 & $\begin{array}{c}1,26 \pm 0,28 \\
(0,69-1,83)\end{array}$ & $\begin{array}{c}0,28 \pm 0,06 \\
(0,15-0,40)\end{array}$ & $\begin{array}{c}2,09 \pm 0,09 \\
(1,91-2,27)\end{array}$ \\
\hline$P$ & & $>0,05$ & $>0,05$ & $2: A, 1<0,05$ \\
\hline
\end{tabular}

Примітка: А - показники в актуальному періоді обстеження; 1 - при першому анамнестичному обстеженні; 2 - під час другого анамнестичного обстеження.

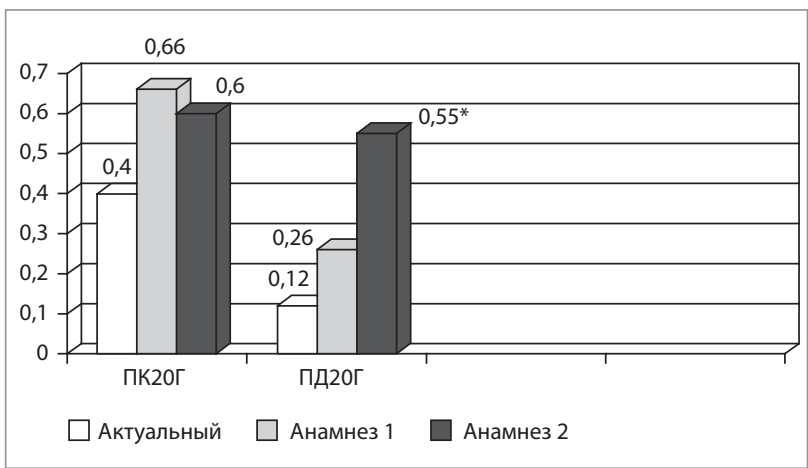

Pис. 1. Показники гіперчутливості на рівні дрібних бронхів (МОШ 25-75) у динаміці спостереження

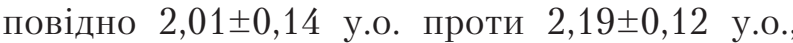
що свідчило про вищий ступінь реактивності і гіперсприйнятливості дихальних шляхів при важкому перебігу захворювання у підлітків.

Оскільки основним рівнем ураження бронхів при БА вважають калібр дрібних та середніх бронхів, було доцільно вивчити чутливість бронхів даного діаметра при якісному аналізі спірограм (рис. 1).

Отримані дані підтверджують вищенаведене припущення, що середньогрупові показники гіперчутливості бронхів у цілому та на рівні дихальних шляхів дрібного калібру можуть розглядатися як відносно стабільна величина. Водночас при оцінці гіперчутливості та, особливо, гіперреактивності бронхів в окремо взятого хворого слід визнати, що величини носять швидше ситуаційний, ніж постійний, характер. Про це свідчить відсутність закономірного зв'язку між наведеними показниками гіперсприйнятливості бронхів у процесі спостереження (табл. 2).

Даний висновок стосується, передусім, показників гіперреактивності бронхів, оскільки 3 позицій проведеного аналізу їх гіперчутливість, як уже зазначалося, можна розглядати як більш сталу величину.

Показник лабільності бронхів (ПЛБ) у хворих на БА можна розглядати як інтегральний показник, який відбиває їх чутливість до непрямого бронхоспазмогенного стимулу у вигляді індексу бронхоспазму і бронхорозши-

Таблиия 2 Результати кореляційного аналізу показників гіперчутливості і гіперреактивності бронхів (ПК20Г/ДЗК)

\begin{tabular}{|l|c|c|c|}
\hline $\begin{array}{c}\text { Рейтинг } \\
\text { спостереження }\end{array}$ & Актуальний & Анамнез 1 & Анамнез 2 \\
\hline Актуальний & & $0,32 / 0,11$ & $0,85^{\star} / 0,04$ \\
\hline Анамнез 1 & $0,32 / 0,11$ & & $0,06 / 0,35$ \\
\hline Анамнез 2 & $0,85^{\star} / 0,04$ & $0,06 / 0,35$ & \\
\hline
\end{tabular}

Примітка: ${ }^{*} \mathrm{P}<0,05$. 
Таблиия 3

Показники лабільності бронхів у динаміці спостереження (95\% ДІ)

\begin{tabular}{|l|c|c|c|c|}
\hline $\begin{array}{c}\text { Період } \\
\text { спостереження }\end{array}$ & $\begin{array}{c}\text { Кількість } \\
\text { дітей }\end{array}$ & плБ, \% & ІБС, \% & ІБд, \% \\
\hline Анамнез 1 & 25 & $\begin{array}{r}28,61 \pm 3,5 \\
(6,6-69,6)\end{array}$ & $\begin{array}{c}11,27 \pm 2,5 \\
(0,1-47,7)\end{array}$ & $\begin{array}{c}17,62 \pm 2,4 \\
(-1,8-43,9)\end{array}$ \\
\hline Анамнез 2 & 11 & $\begin{array}{r}22,23 \pm 4,2 \\
(7,6-47,5)\end{array}$ & $\begin{array}{c}8,57 \pm 2,7 \\
(-2,5-30,0)\end{array}$ & $\begin{array}{c}14,56 \pm 2,9 \\
(3,3-37,7)\end{array}$ \\
\hline Актуальний & 42 & $\begin{array}{c}19,17 \pm 2,7 \\
(13,7-24,6)\end{array}$ & $\begin{array}{c}7,16 \pm 1,99 \\
(3,1-11,2)\end{array}$ & $\begin{array}{c}12,03 \pm 0,28 \\
(7,4-16,6)\end{array}$ \\
\hline $\mathrm{P}$ & $\mathrm{A}: 1<0,05$ & $>0,05$ & $\mathrm{~A}: 1<0,05$ & \\
\hline
\end{tabular}

Примітка: ПЛБ - показник лабільності бронхів; ІБС - індекс бронхоспазму; ІБД - індекс бронходиляції.

Таблиия 4

Показники лабільності бронхів за різного ступеня важкості бронхіальної астми в обстежених підлітків (95\%ДІ)

\begin{tabular}{|l|c|c|c|}
\hline \multicolumn{1}{|c|}{ Важкість БА } & ПЛБ, \% & ІБС, \% & ІБД, \% \\
\hline \multirow{2}{*}{ Легка } & $9,26 \pm 0,13$ & $3,66 \pm 2,2$ & $5,6 \pm 2,14$ \\
& $(0,12-1,45)$ & $(1,98-23,9)$ & $(1,93-23,28)$ \\
\hline \multirow{2}{*}{ Середньоважка } & $13,18 \pm 3,93$ & $1,41 \pm 2,13$ & $10,37 \pm 3,18$ \\
& $(12,9-25,3)$ & $(6,8-13,5)$ & $(10,5-20,5)$ \\
\hline \multirow{2}{*}{ Важка } & $27,7 \pm 4,2$ & $12,3 \pm 3,34$ & $16,86 \pm 4,07$ \\
& $(12,8-26,1)$ & $(9,5-20,4)$ & $(12,5-25,6)$ \\
\hline Р & Т:Л,С <0,05 & Т:Л,С <0,05 & Т:Л <0,05 \\
\hline
\end{tabular}

Примітка: Л - легка, С - середньоважка, Т - важка

рювальний ефект бета2-агоніста швидкої та короткої дії (сальбутамолу) як індексу бронходиляції.

У табл. 3 наведені динамічні показники (у \%) індексів бронхоспазму та бронходиляції та показника лабільності бронхів. При цьому збільшення даних маркерів свідчить про виразніший спазмогенний ефект дозованого фізичного навантаження і бронхорозширювальний ефект сальбутамолу.

Отримані результати дозволяють припустити, що попри середньогрупову варіацію ПЛБ, найбільш стабільним показником слід вважати їх здатність до дезобструкції під впливом сальбутамолу, що, мабуть, відображує подібний рівень їх ремоделяції, або сальбутамолзалежних механізмів обструкції.

Виходячи з цього, у динаміці спостереження вивчено ПЛБ залежно від важкості перебігу астми (табл. 4).

Таблиия 5

Результати кореляційного аналізу показників лабільності бронхів (ПЛБ/ІБС/ІБД) у динаміці спостереження

\begin{tabular}{|l|c|c|c|}
\hline $\begin{array}{c}\text { Рейтинг } \\
\text { спостере- } \\
\text { ження }\end{array}$ & Актуальний & Анамнез 1 & Анамнез 2 \\
\hline Актуальний & & $0,29 / 0,07 / 0,64^{*}$ & $0,03 /-0,16 / 0,25$ \\
\hline Анамнез 1 & $0,29 / 0,07 / 0,64^{*}$ & & $0,57 / 0,72^{*} / 0,3$ \\
\hline Анамнез 2 & $0,03 /-0,16 / 0,25$ & $0,57 / 0,72^{*} / 0,3$ & \\
\hline
\end{tabular}

Взаємозв'язок показників неспецифічної гіперсприйнятливості бронхів до прямих і непрямих стимулів у міжнападовому періоді

\begin{tabular}{|c|c|c|c|c|c|}
\hline Показник & $\begin{array}{l}\text { IEC } \\
\text { (\%) }\end{array}$ & $\begin{array}{l}\text { ІБД } \\
\text { (\%) }\end{array}$ & $\begin{array}{l}\text { пЛБ } \\
\text { (\%) }\end{array}$ & $\begin{array}{c}\text { ПК20Г } \\
\text { (мг/мл) }\end{array}$ & $\begin{array}{l}\text { д3К } \\
\text { (y.o.) }\end{array}$ \\
\hline $\begin{array}{l}\text { IEC } \\
(\%)\end{array}$ & & $\begin{array}{l}r=-0,03 \\
P=0,84\end{array}$ & $\begin{array}{l}r=0,67^{*} \\
P=0,001\end{array}$ & $\begin{array}{l}r=-0,37 \\
P=0,06\end{array}$ & $\begin{array}{l}\mathrm{r}=0,47^{*} \\
\mathrm{P}=0,01\end{array}$ \\
\hline $\begin{array}{l}\text { ІБД } \\
(\%)\end{array}$ & $\begin{array}{l}r=-0,03 \\
P=0,84\end{array}$ & & $\begin{array}{l}r=0,76^{*} \\
P=0,001\end{array}$ & $\begin{array}{l}r=-0,33 \\
P=0,08\end{array}$ & $\begin{array}{l}r=0,35 \\
P=0,08\end{array}$ \\
\hline $\begin{array}{c}\text { ПЛБ } \\
(\%)\end{array}$ & $\begin{array}{l}r=0,67^{\star} \\
P=0,001\end{array}$ & $\begin{array}{l}r=0,76^{*} \\
P=0,001\end{array}$ & & $\begin{array}{l}r=-0,47^{*} \\
P=0,01\end{array}$ & $\begin{array}{l}r=0,54^{*} \\
P=0,004\end{array}$ \\
\hline $\begin{array}{l}\text { ПК20Г } \\
\text { (мг/Мл) }\end{array}$ & $\begin{array}{l}r=-0,37 \\
P=0,06\end{array}$ & $\begin{array}{l}r=-0,33 \\
P=0,08\end{array}$ & $\begin{array}{c}r=-0,47^{*} \\
P=0,01\end{array}$ & & $\begin{array}{l}r=-0,82^{*} \\
P=0,001\end{array}$ \\
\hline $\begin{array}{l}\text { ДЗК } \\
\text { (y.o.) }\end{array}$ & $\begin{array}{l}r=0,47^{*} \\
P=0,01\end{array}$ & $\begin{array}{l}r=0,35 \\
P=0,08\end{array}$ & $\begin{array}{l}r=0,54^{*} \\
P=0,004\end{array}$ & $\begin{array}{l}r=-0,82^{*} \\
P=0,001\end{array}$ & \\
\hline
\end{tabular}

Примітка: ${ }^{*} \mathrm{P}<0,05$.

Отримані результати вказують на те, що по мірі посилення важкості захворювання у підлітків зростає лабільність бронхів, за середньоважкого варіанту переважно за рахунок ІБД, а за важкого - ще й за рахунок виникнення бронхоспазму фізичного напруження.

У табл. 5 наведені взаємозв'язки, за даними лінійної кореляції, між ПЛБ та його компонентами у кожного окремого хворого у динаміці спостереження.

Отримані дані дають підстави вважати, що попри меншу стандартизацію проби з фізичним навантаженням стосовно інгаляційної бронхопровокаційної проби з гістаміном, вона так само, як і оцінка ГЧБ до вказаного медіатора, дає відтворювані результати в окремому дослідженні. У зв'язку з цим, як оцінку гіперчутливості дихальних шляхів до гістаміну, так і оцінку лабільності бронхів у пробі з фізичним навантаженням і фармакологічним бронхорозширювальним тестом, в окремому дослідженні можна екстраполювати на вказані характеристики неспецифічної ГСБ у підлітків у міжнападовому періоді.

У табл. 6 наведена сила лінійного кореляційного зв'язку показників гіперчутливості (ПК20Г), гіперерактивності (ДЗК) до гістаміну та маркерів лабільності бронхів (ІБС, ІБД, ПЛБ).

Отримані дані дають підстави вважати, що ГСБ до прямих і непрямих стимулів у міжнападовому періоді, мабуть, поєднує спільні механізми, до яких, перш за все, слід віднести запалення дихальних шляхів, а неспецифічну ГРБ у дітей, мабуть, слід розглядати як мультифакторний феномен, а скоріше - епіфеномен БА, що підтверджується результатами багатофакторного кореляційного аналізу виразності НГСБ у підлітків у міжнападовому 
періоді захворювання до прямих і непрямих стимулів.

\section{Висновки}

1. За середньоважкого перебігу БА гіперчутливість бронхів була меншою, ніж за важкого перебігу, і становила (ПК20Г) 1,58 $\pm 0,5$ мг/мл проти 1,04 $\pm 0,4$ мг/мл, реактивність бронхів за даними дозозалежної кривої становила $2,01 \pm 0,14$ у.о. проти $2,19 \pm 0,12$ у.о. відповідно, що свідчило про вищий ступінь реактивності дихальних шляхів при важкому перебігу захворювання у підлітків.

2. По мірі посилення важкості захворювання у підлітків зростає лабільність бронхів, за середньоважкого варіанту переважно за рахунок ІБД, а за важкого - також і за рахунок виникнення бронхоспазму фізичної напруги.

3. Гіперсприйнятливість дихальних шляхів до прямих і непрямих стимулів у міжнападовому періоді, мабуть, поєднує спільні механізми, до яких слід віднести, передусім, запалення дихальних шляхів, а неспецифічну гіперреактивність бронхів у дітей підліткового віку, мабуть, слід розглядати як мультифакторний феномен, а скоріше - епіфеномен БА.

Перспективи подальших досліджень полягають у визначенні у дітей підліткового віку з БА параклінічних маркерів, які відображають основні характеристики захворювання - запалення та гіперсприйнятливість дихальних шляхів.

Автори заявляють про відсутність конфлікту інтересів.

\section{ЛITEPATУPA}

1. Anderson SD, Freed R, Wyndham J. (2002). The use of bronchial provocation tests for identifying asthma. Respiratory Medicine. 3:77-85.

2. Cockcroft DW, Davis BE. (2006). Mechanisms of airway hyperresponsiveness. J Allergy Clin Immunol. 118: 551-559.

3. Dell SD, Bola SS, Foty RG et al. (2015). PD20 Should be Used to Interpret Methacholine Challenge Tests with Modern Nebulizers. Annals of the American Thoracic Society.

4. Grootendorst DC, Rabe KF. (2004). Mechanisms of bronchial hyperreactivity in asthma and chronic obstructive pulmonary disease. Proc Am Thoracic Soc. 1:77-87.

5. Koh Y, Kang EK, Kang H. (2003). Bronchial hyperresponsiveness in adolescents with long-term asthma remission: importance

of a Family history of bronchial hyperresponsiveness. Chest.124:819-825.

6. Mochizuki H, Muramatsu R, Hagiwara S et al. (2009). Relationship between bronchial hyperreactivity and asthma remission during adolescence. Ann. Allergy Asthma Immunol. 103;3:201-205.

7. Sumino K, Sugar EA, Irvin CC et al. (2014). Variability of methacholine bronchoprovocation and the effect of inhaled corticosteroids in mild asthma. Ann Allergy Asthma Immunol.112(4):354-360.

8. Walsh GM. (2013). An update on biologic-based therapy in asthma Immunotherapy. 5(11):1255-1264.

9. Wang F, He XY, Baines KJ et al. (2011). Different inflammatory phenotypes in adults and children with acute asthma. Eur Respir J.38:567-574.

\section{Сведения об авторах:}

Колоскова Елена Константиновна - д.мед.н., проф., зав. каф. педиатрии и детских инфекционных болезней ВГузу «Буковинский государственный медицинский университет . Адрес: г. Черновцы, ул. Русская, 207А; тел. (0372) 575-660.

Тарнавская Светлана Ивановна - к.мед.н., доц. каф. педиатрии и детских инфекционных болезней ВГУзУ «Буковинский государственный медицинский университет». Адрес: г. Черновцы, ул. Русская, 207А; тел. (0372) 575-660

Шахова Ольга Александровна - к.мед.н., ассистент каф. и детских инфекционных болезней ВГУЗУ «Буковинский государственный медицинский университет».

Адрес: г. Черновцы, ул. Русская, 207А; тел. (0372) 575-660.

Манилич Инна Александровна - врач ультразвуковой диагностики КМУ «Областная детская клиническая больница». Адрес: г. Чернивцы, ул. Русская, 207А; тел. (0372) 575-660.

Статья поступила в редакцию 07.11.2018 г; принята в печать 05.03.2019 г. 


\title{
Вроджений гіпотиреоз: скринінг, діагностика та лікування з огляду на сучасні міжнародні рекомендації
}

Національна академія післядипломної освіти імені П.Л. Шупика, м. Київ, Україна

SOVREMENNAYA PEDIATRIYA.2019.2(98):45-52; doi 10.15574/SP.2019.98.45

\begin{abstract}
внутрішньоутробного розвитку, проявляється клінічно відразу після народження або у перші місяці життя. потенціальний розвиток, порівнянний із таким у однолітків. неможливості отримати достатню кількість йоду з продуктами харчування.

Ключові слова: діти, вроджений гіпотиреоз, діагностика, лікування, профілактика.

\section{Congenital Hypothyroidism: Screening, Diagnosis and Treatment from the Perspective of Current International Guidelines M.E. Mamenko}

Shupyk National Medical Academy of Postgraduate Education, Kyiv, Ukraine
\end{abstract}

Вроджений гіпотиреоз — патологічний стан, пов'язаний із десріцитом продукції гормонів щитоподібної залози, основа якого закладається ще під час

Сучасні стратегії діагностики та лікування вродженого гіпотиреозу ґрунтуються на проведенні неонатального скринінгу та ранньому початку лікування. У даній публікації наведений огляд міжнародних та вітчизняних гайдлайнів. Найважливіший акцент цих рекомендацій - своєчасний початок лікування (зазвичай не пізніше двох тижнів від народження) та більш активні стратегії ведення хворих у ранньому віці, що забезпечує дитині

Вроджений гіпотиреоз вважається єдиною формою розумової недостатності, яку можна попередити шляхом сапліментації під час вагітності за

Congenital hypothyroidism is a pathological condition associated with deficiency of thyroid hormone production, the foundation of which is laid during intrauterine development. Clinically it manifests itself immediately after birth or in the first months of life.

Currently the strategies for the diagnosis and treatment of $\mathrm{CH}$ are based on neonatal screening and early onset of treatment. This publication presents an overview of international and domestic guidelines. The biggest emphasis of these guidelines is made on the timely initiation of treatment (usually not later than two weeks after birth) and on more active strategies for the management of patients at an early age, which provides the child with potential development comparable to that of peers.

Congenital hypothyroidism is considered to be the only form of mental retardation that can be prevented by supplementation during pregnancy if it is impossible to obtain a sufficient amount of iodine with food.

Key words: children, congenital hypothyroidism, diagnosis, treatment, prevention.

\section{Врожденный гипотиреоз: скрининг, диагностика и лечение в соответствии с современными международными рекомендациями \\ М.Е. Маменко \\ Национальная академия последипломного образования имени П.Л. Шупика, г. Киев, Украина}

Врожденный гипотиреоз - патологическое состояние, связанное с дефицитом продукции гормонов щитовидной железы, основа которого закладывается еще во время внутриутробного развития, проявляется клинически сразу после рождения или в первые месяцы жизни.

Современные стратегии диагностики и лечения врожденного гипотиреоза основываются на проведении неонатального скрининга и раннем начале лечения. В данной публикации приведен обзор международных и отечественных гайдлайнов. Наиважнейший акцент этих рекомендаций своевременное начало лечения (как правило, не позже двух недель от рождения) и более активные стратегии ведения больных в раннем возрасте, что обеспечивает ребенку потенциальное развитие, сравнимое с таковым у сверстников.

Врожденный гипотиреоз считается единственной формой умственной недостаточности, которую можно предотвратить путем саплиментации во время беременности при невозможности получить достаточное количество йода с продуктами питания.

Ключевые слова: дети, врожденный гипотиреоз, диагностика, лечение, профилактика.

Вроджений гіпотиреоз (ВГ) - патологічний стан, пов'язаний із дефіцитом продукції гормонів щитоподібної залози (ЩЗ), основа якого закладається ще під час внутрішньоутробного розвитку, проявляється клінічно відразу після народження або у перші місяці життя. 3 точки зору етіології, це захворювання слід розглядати як гетерогенне, оскільки до його розвитку призводить низка різноманітних причин: йодний дефіцит (ЙД), агенезія, аплазія, ектопія ЩЗ, генетично детерміновані порушення тиреоїдного гормоногенезу тощо (табл. 1). Зазвичай цей стан потребує довічної терапії, хоча трапляються випадки транзиторного неонатального гіпотиреозу, які виникають унаслідок прийому матір'ю окремих медикаментів, трансплацентарної передачі блокуючих антитіл або Йд. Також використовується термін «гіпертиротропінемія» для опису форми компенсованого ВГ, за якої спостерігається легке підвищення концентрації тиреотропного гормону (ТТГ), зазвичай на рівні 6-20 мОд/л, при нормальних концентраціях гормонів Щ3 [4,5].

Так само як і набутий, ВГ можна поділити на первинний (тиреогенний) та центральний (гіпофізарний та/або гіпоталамічний). Він вважається компенсованим, якщо рівні вільного тироксину знаходяться у межах референтних значень, та декомпенсованим, якщо вони починають знижуватись. Крім того, виділяють так 
званий «пізній» гіпотиреоз, клінічні прояви якого з'являються на 3-4 місяці життя та навіть пізніше [3,5].

Найбільш поширеною формою ВГ є первинний гіпотиреоз із високим рівнем ТТГ, який пов'язаний із різними формами тиреоїдного дисгенезу або дисгормоногенезу. Вторинний гіпотиреоз зустрічається набагато рідше та є наслідком або ізольованого дефіциту продукції ТТГ, або, частіше, у поєднанні з пангіпопітуатаризмом [3].

У будь-якому випадку дефіцит продукції тиреоїдних гормонів (ТГ) у періоді новонародженості та раннього дитинства вкрай небезпечний для росту та розвитку дитини. Особливо чутливим до нестачі ТГ є мозок, оскільки формування його структури продовжується у перші 2-3 роки життя та безпосередньо залежить від тиреоїдного статусу. Адже до функції ТГ належать стимуляція дозрівання і міграції нервових клітин, збільшення утворення мієліну; стимуляція розгалуження дендритів та утворення синапсів, вплив на інші нейротрансмітери, ферменти та клітинні протеїни [4].

Зважаючи на значення ВГ для розвитку дитини, а також на те, що за умови своєчасної діагностики та раннього початку лікування його важкі наслідки можуть бути попереджені, рекомендації щодо скринінгу, діагностики та лікування даного стану створюють не тільки ендокринологічні, але й педіатричні асоціації. У даній публікації наведений огляд міжнародних та вітчизняних гайдлайнів. Найважливіший акцент цих рекомендацій - своєчасний початок лікування (зазвичай не пізніше двох тижнів від народження) та більш активні стратегії ведення пацієнтів у ранньому віці, що забезпечує дітям потенціальний розвиток, порівнянний із таким у однолітків. Уроджений гіпотиреоз, як і раніше, вважається єдиною формою розумової недостатності, яку можна повністю попередити $[1,3,5]$.

Неонатальний скринінг. Стратегії раннього виявлення випадків ВГ існують у найбільш розвинених країнах світу із $80-x$ років минулого сторіччя. Необхідність неонатального скринінгу грунтується на відносно високій частоті даного захворювання, доступності скринінгових тестів, доступності та ефективності лікування, а також очевидності ризиків при пізній діагностиці цього стану.

Для ілюстрації ефективності проведення скринінгових програм Європейська Асоціація Дитячих Ендокринологів (ESPE) наводить наступні дані: до початку скринінгу ВГ діагнос- тували у 1 з 6700 живонароджених, а вже у 2000 році, після його запровадження, у 1 на 3000 живонароджених [3]. Зазвичай витрати бюджету на проведення скринінгу повністю виправдовуються за рахунок коштів, які були збережені завдяки усуненню необхідності покривати лікування та догляд за пацієнтами із пізньою діагностикою ВГ.

Існують три стратегії скринінгу для виявлення ВГ: первинне вимірювання ТТГ із резервним визначенням тироксину (Т4) у дітей з високим рівнем ТТГ; первинне вимірювання Т4 з резервною оцінкою ТТГ у дітей з низьким рівнем Т4; i одночасне вимірювання рівнів Т4 і ТТГ. Кожний із методів має власні обмеження. Так, вимірювання ТТГ під час скринінгу, що використовується в Україні, як і в більшості країн світу, орієнтоване на найпоширенішу форму ВГ (первинний, або тиреогенний, гіпотиреоз), а відтак $€$ шанси пропустити затримку підвищення ТТГ у дітей з дефіцитом тироксинзв'язуючого глобуліну (ТЗГ), центральним гіпотиреозом або гіпотироксинемією. Крім того, додаткові проблеми створює сучасна тактика щодо ранньої виписки з пологового будинку, адже постнатальне збільшення ТТГ є нормою. Незважаючи на певні недоліки, вимірювання рівня ТТГ вважається найбільш чутливим тестом для діагностики ВГ [3,5].

Вимірювання Т4 із резервною оцінкою ТТГ виявляє первинний гіпотиреоз, дефіцит ТЗГ, центральний гіпотиреоз i, потенційно, гіпертироксинемію, проте цей метод пропускає легкі форми первинного гіпотиреозу. Одночасне вимірювання ТТГ та Т4 є ідеальним підходом, але його використання обмежується високою вартістю.

ESPE, Американська тиреоїдна асоціація (ATA) та Американська академія педіатрії (AАР) вважають оптимальним часом для проведення скринігу період від 48 до 72 годин від народження на світ. Якщо це неможливо, тестування слід проводити перед випискою або протягом семи днів після народження. Хибно-позитивні підвищення ТТГ можуть бути виявлені у зразках, зібраних через 24-48 годин після народження, а хибно-негативні результати можуть бути виявлені у важко хворих новонароджених або новонароджених після трансфузіі. ААР у своїх гайдлайнах підкреслює важливість проведення скринінгу у дітей, які отримують екстрену допомогу [5].

Найбільш вагомою причиною проведення неонатального скринінгу є можливість попере- 
дити розумову недостатність та забезпечити потенційно нормальний рівень інтелекту. Зараз показники неонатального скринінгу на ВГ ВООЗ, ЮНІСЕФ та МРКЙДЗ рекомендують у якості індикатора йодного забезпечення матері та плода при проведенні оцінки йодного статусу в популяції у цілому [6].

Незважаючи на те, що скринінгові програми зосереджені перш на все на важких формах ВГ, триває дискусія щодо впливу легких форм та транзиторного гіпотиреозу на розвиток дитини.

Попри наявність стандартних вимог до проведення скринінгу, існують групи особливого ризику, які потребують окремої тактики. Так, вітчизняні протоколи рекомендують проводити скринінг передчасно народженим дітям у період з 7 по 14 добу життя [1]. ESPE рекомендує стратегію «другого скринінгу» для недоношених новонароджених із гестаційним віком менше 37 тижнів; новонароджених iз низькою та екстремально низькою масою тіла при народженні; хворих і недоношених новонароджених, які знаходилися у відділеннях інтенсивної терапї; у випадках, коли збір перших зразків здійснювався протягом перших 24 годин життя; для дітей, які з'явилися на світ унаслідок багатоплідної вагітності, особливо у випадках одностатевих близнюків. Повторні зразки повинні бути зібрані приблизно через 2 тижні після народження або через 2 тижні після першого скринінгового тесту [3]. Інтерпретація результатів скринінгу має враховувати результати всіх зразків. Особлива тактика у таких новонароджених зумовлена більш виразними та тривалими зсувами з боку гіпофізарно-тиреоїдної системи у період після народження, використанням медикаментозних засобів, можливістю змішування крові при багатоплідній вагітності тощо. За наявності високих показників ТТГ при проведенні другого скринінгу у новонароджених, у яких перші результати були нормальними, необхідно терміново розпочати пошук причини такого збільшення та лікування дитини, хоча частіше такий гіпотиреоз є вторинним.

У рекомендаціях ESPE запропонована наступна тактика при оцінці результатів неонатального скринінгу [3]:

- розпочати лікування відразу після визначення рівня ТТГ і вільного Т4, якщо концентрація ТТГ становить $\leq 40$ мОд/л цільної крові. Якщо концентрація <40 мОд/л цільної крові, клініцист може відкласти лікування, очікуючи результатів повторно- го визначення показників у сироватці протягом 1-2 днів;

• негайно розпочати лікування, якщо концентрація вільного Т4 у сироватці нижче норми для віку, незалежно від концентрації ТТГ;

• розпочати лікування, якщо концентрація ТТГ у венозній системі постійно становить $>20$ мОд/л, навіть якщо концентрація вільного Т4 у сироватці є нормальною.

При концентрації ТТГ від 6 до 20 мОд/л та вільного Т4 у межах норми для віку ESPE рекомендує провести діагностичний пошук, щоб спробувати встановити причину. Якщо концентрація ТТГ залишається високою протягом понад 3-4 тижні, пропонується починати прийом левотироксину (за згоди батьків) і провести повторне тестування на більш пізній стадії, після відміни лікування на 2 тижні [3].

Згідно з чинним в Україні протоколом надання медичної допомоги дітям, хворим на гіпотиреоз, забір капілярної крові проводиться перед випискою із пологового будинку на третю добу життя з п'яткової ділянки новонародженого немовляти 3 подальшим імуноферментним аналізом висушеного зразка на спеціальному паперовому диску. Абсолютною нормою вважається рівень ТТГ $<5$ мОД/л. Усі результати дослідження нижче 20 мОД/л вважаються варіантом норми і не вимагають подальшого обстеження немовляти. При рівні ТТГ в межах 20-50 мОД/л проводять визначення концентрацій ТТГ і вільного Т4 у сироватці крові. При концентрації ТТГ у сироватці венозної крові понад $100 \mathrm{мОД/л} \mathrm{і} \mathrm{Т4} \mathrm{віл.<120} \mathrm{нмоль/л}$ негайно призначають замісну терапію L-тироксином. При ТТГ у межах 20-50 мОД/л і Т4 віл.>120 нмоль/л проводять повторні дослідження через 7 і 30 днів. Замісна терапія призначається при наростанні рівня ТТГ. При рівні ТТГ у капілярній крові 50-100 мОД/л вважають, що ймовірність ВГ висока, і лікування призначають, не чекаючи результатів контрольного дослідження. Якщо при контрольному тестуванні рівні ТТГ і вільного тироксину виявляться нормальними, лікування припиняють [1].

При рівні ТТГ понад 100 мОД/л негайно повідомляють у поліклініку за місцем проживання дитини про виявлення випадку ВГ. Проводять повторний забір крові для визначення рівнів ТТГ і тироксину в сироватці. Не чекаючи результатів, призначають замісну терапію левотироксином. Якщо контрольні досліджен- 
Таблиия 1

Причини вродженого гіпотиреозу (European Society for Paediatric Endocrinology consensus guidelines, 2014)

Тиреоїдний дисгенез

Уявний гіпотиреоз

Справжній атиреоз

Ектопія

Гіпоплазія in situ

Геміагенез

Дисгормоногенез

$\mathrm{NIS/SCL5A5}$

Тиреопероксидаза (ТПО)

DUOX2/DUOXA2

Тиреоглобулін (ТГ)

Pendred синдром, pendrin PDS / SCL26A4

Дегалогенеза (IYD/DEHAL1)

Транзиторний вроджений гіпотиреоз

Гострий надлишок йоду

Хронічна йодна недостатність

Материнські блокуючі антитіла

Рецептори ТТГ

ня виявляться негативними, лікування припиняють. При підтвердженні діагнозу лікування продовжують під контролем педіатра і дитячого ендокринолога [1]

Оцінка важкості ВГ. ESPE рекомендує оцінювати ступінь важкості ВГ клінічно на основі виразності симптомів гіпотиреозу (табл. 2); біологічно - на основі визначення сироваткових рівнів Т4 вільного ( $<5$ пмоль/л важкий, 5-10 пмоль/л - середньої важкості, 10-15 пмоль/л - легкий); на підставі уповільненого епіфізарного дозрівання на рентгенограмі коліна; і з точки зору етіології ВГ. Концентрація тиреоглобуліну у сироватці нижче порогу виявлення свідчить про наявність атиреозу або повного дефекту синтезу тиреоглобуліну [3].

Місце візуалізації у діагностиці ВГ. ESPE рекомендує проводити візуалізаційні дослідження (УЗД та сцинтиграфію) для визначення конкретної етіології ВГ у новонароджених із високою концентрацією ТТГ. Час проведення цих досліджень не повинен впливати на початок замісної терапії. Якщо у немовляти при первинному дослідженні візуалізується ЩЗ нормального розміру в типовому місці, необхідно повторити дослідження в динаміці [3].

Сцинтиграфія дозволяє ідентифікувати атиреоз (відсутність поглинання), гіпоплазію залози in situ, нормальну або велику залозу in situ, а також ектопію Щ3.

Ультразвукове дослідження може бути використане для визначення відсутності або наявності ЩЗ, вимірювання розміру, вивчення ехогенності і структури Щ3, яка розташована у типовому місці. Проте цей метод не завжди може виявити лінгвальну і сублінгвальну ектопію Щ3, хоча використання кольорового допплера полегшує ідентифікацію тиреоїдної тканини, демонструючи помітне збільшення кровотоку. Експерти міжнародних організацій вважають, що якість ультрасонографії залежить від кваліфікації спостерігачів, а отже до висновків завжди потрібно ставитись з обережністю та переглядати результати в динаміці.

Існують також рекомендації щодо поєднання сцинтиграфії та УЗД. Це дозволяє: підвищити точність діагностики; вивчити залозу, що розташована у типовому місці, яка при ВГ може бути нормальною, збільшеною або гіпопластичною (це визначає напрями генетичних досліджень); запобігти неправильній діагностиці атиреозу в умовах відсутності поглинання на сцинтиграфіï, коли ультразвук показує нормальну залозу in situ; надійно виявляти ектопію Щ3 [3].

Про які супутні патологічні стани слід думати у дітей із ВГ. Усім новонародженим, у яких виявлена висока концентрація ТТГ, слід провести ретельне обстеження для виявлення інших вроджених вад розвитку, особливо серцево-судинної системи, а також оцінити сукупність дисморфологічних ознак для виявлення порушень нейрогенезу та/або основного дисморфічного синдрому. Такі рекомендації грунтуються на доказах, що поширеність вроджених вад розвитку, зокрема серцевих вад, у тому числі дефектів перегородок, ниркових аномалій та ризику розвитку нейрореактивних розладів, вища в осіб із ВГ, ніж у загальній популяції. Проте слід пам'ятати, що у дітей iз вадами розвитку часто зустрічається транзиторне підвищення ТТГ, яке необов'язково пов'язане із тиреоїдною патологією [3].

Помірним підвищенням концентрації ТТГ у неонатальному періоді часто супроводжується синдром Дауна, хоча зазвичай підвищення незначне та не виявляється під час неонатального скринінгу. Pendred синдром із зобом або без нього, а також псевдогіпопаратиреоз, можуть супроводжуватися підвищенням ТТГ різного ступеня, що потребує диференційної діагностики у пацієнтів із типовим розташуванням Щ3 [3,5].

Лікування. Рекомендації АAP, ESPE, ATA та вітчизняного протоколу єдині у ключових моментах. Терапію слід розпочати якомога раніше. Когнітивні результати залежать від термінів та адекватності лікування [1,2,3,5]. 
Основні симптоми

та ознаки вродженого гіпотиреозу [4]

\begin{tabular}{|c|c|}
\hline Новонароджений & Дитина 1-го року життя \\
\hline Переношеність & Тривала фрізілогічна жовтяниця \\
Макросомія & Знижений апетит, млявість \\
Велика голова & Сонливість \\
Відкрите заднє тім'ячко & Гіпотермія \\
Затримка розвитку скелету & Запори \\
& Макроглосія \\
& Хрипкий крик \\
& Пупкова грижа \\
& Суха шкіра \\
& Зоб \\
\hline
\end{tabular}

«Золотим стандартом» залишається використання левотироксину перорально. Трийодтиронін не застосовується. Левотироксин призначається відразу після встановлення діагнозу шляхом повної замісної терапії у дозі 10-15 мкг/кг/день. Немовлята 3 важким гіпотиреозом, який проявляється дуже низькою концентрацією загального та/або вільного тироксину, можуть отримувати навіть вищі дози левотироксину. У подальшому доза коригується відповідно до динаміки змін рівнів ТТГ та вільного Т4. Соя, клітковина і залізо можуть знижувати біодоступність левотироксину, тому їх слід уникати.

Левотироксин можна приймати вранці або ввечері, краще перед годуванням, у немовлят можна 3 іжею, але в один і той самий спосіб щодня. Для новонароджених i немовлят таблетки можна подрібнювати та розмішувати із невеликою кількістю рідини в ложці. Виписувати левотироксин рекомендується обов'язково брендовою або генеричною назвою, а не субстанцією.

Експерти міжнародних організацій вважають, що батькам слід надати письмові інструкції щодо лікування левотироксином, щоб зменшити вірогідність низького лікувального комплаєнсу.

Біохімічна мета терапії - нормалізація рівня загального та вільного тироксину протягом двох тижнів від початку лікування, а ТТГ -

Дози левотироксину

таблиия 3

для лікування вродженого гіпотиреозу [1]

\begin{tabular}{|l|c|}
\hline \multicolumn{1}{|c|}{ Вік } & Добова доза, мкг/кг \\
\hline Недоношені & $8-10$ \\
\hline $0-3$ міс. & $10-15$ \\
\hline 3-6 міс. & $8-10$ \\
\hline $6-12$ міс. & $6-8$ \\
\hline 1-3 роки & $4-6$ \\
\hline 3-10 роки & $3-4$ \\
\hline 10-15 роки & $2-4$ \\
\hline Старше 15 років & $2-3$ \\
\hline
\end{tabular}

протягом одного місяця. Якщо концентрація вільного Т4 у сироватці не збільшується до верхньої половини референтного діапазону за два тижні, або якщо концентрація ТТГ не опускається нижче 20 мОд/л протягом чотирьох тижнів, ААР рекомендує оцінити відповідність дозування та способу введення. Вищі дози левотироксину (12-17 мкг/кг) здатні підвищити рівень Т4 швидше, але слід пам'ятати про можливість передозування та підсилити контроль за ходом лікування.

Дози левотироксину, які рекомендовані для лікування ВГ в Україні Протоколом надання допомоги дітям, хворим на гіпотиреоз, у цілому збігаються з такими, які застосовуються в світі (табл. 3) [1].

Протягом перших трьох років життя дитини з ВГ слід намагатися тримати показники загального та вільного тироксину у верхній половині референтного діапазону, а рівень ТТГ у сироватці повинен становити від 0,5-2,0 мОд/л. Якщо між динамікою показників є певна невідповідність (наприклад, нормальна або підвищена концентрація Т4 у сироватці з невідповідно високим рівнем ТТГ), дозу слід титрувати, орієнтуючись на концентрацію Т4.

Спостереження. Контроль за лабораторними та клінічними ознаками ВГ має бути особливо ретельним протягом перших трьох років життя для забезпечення оптимального лікування. Для цього використовують вимірювання сироваткового Т4 і ТТГ, які ААР рекомендує проводити через два та чотири тижні після початку лікування, а потім кожні 1-2 місяці до шести місяців, кожні 3-4 місяці від шести місяців до трьох років життя, кожні 6-12 місяців до дорослості і через чотири тижні після будь-якої зміни дози. ESPE рекомендує зразки крові для лабораторної оцінки збирати принаймні через чотири години після останнього введення левотироксину. Контрольні дослідження мають виконуватися частіше, якщо існує підозра щодо недотримання режиму лікування або виявляються симптоми гіпо- чи гіпертиреозу. Вимірювання слід також проводити через 4-6 тижнів після будь-якої зміни дози левотироксину або препарату (марки) левотироксину [3].

За необхідності лікування слід коригувати відповідно до виміряних концентрацій гормонів, але зниження дози левотироксину не повинно грунтуватися на одній високій концентрації вільного Т4 під час лікування. Також слід враховувати метод визначення та рефе- 
рентні інтервали, які використовує конкретна лабораторія.

У дітей з наявністю важкої патології слід застосовувати більш низькі дози левотироксину. Наприклад, при серцевій недостатності пропонується розпочати лікування із дози левотироксину на 50\% нижче від очікуваної замісної і збільшувати їі відповідно до рівнів вільного Т4 через два тижні.

Частота побічних явищ під час лікування левотироксином дуже низька.

Прогноз ВГ залежить від його причини. Якщо має місце ектопія Щ3 або при скануванні відсутня їі тканина, гіпотиреоз є перманентним та потребуватиме довічного лікування. Також на постійний характер гіпотиреозу може вказувати рівень ТТГ у сироватці крові понад 10 мОд/л у віці старше року життя. Якщо таких ознак виявлено не було, ААР пропонує припинити терапію на 30 днів після виповнення дитині трьох років. Якщо при проведенні вимірювань вільного Т4 та ТТГ через 30 днів від припинення замісної терапії результати знаходяться в межах референтних значень, може бути зроблений висновок про транзиторний характер гіпотиреозу. Якщо результати вийшли за межі референтного діапазону, лікування відновлюють. Також можливе застосування альтернативної тактики - зменшення дози на половину протягом 30 днів, при цьому рівень ТТГ вище 20 мОд/л підтверджує постійний ВГ [3].

Консультування батьків є важливим через серйозні наслідки поганого дотримання рекомендацій щодо діагностики та лікування, тому міжнародні гайдлайни присвячують цим питанням окремі розділи.

Так, ESPE наголошує, що про високу концентрацію ТТГ за результатами неонатального скринінгу необхідно повідомити сім'ю, сімейного лікаря та місцевого педіатра. Сім'ю слід повідомити по телефону або особисто якнайшвидше. Причому інформацію має передати досвідчена особа, така як член персоналу скри- нінгової лабораторії або ендокринолог. Зв'язок може бути безпосередньо із сім'єю або через сімейного лікаря, патронажну сестру чи акушерку. Бажано оглянути дитину та провести тестування функції Щ3 шляхом визначення ТТГ та вільного Т4 у венозній крові у день отримання інформації або не пізніше наступного дня [3].

Лікувальні заклади повинні мати відповідні інформаційні матеріали про діагностику та лікування ВГ на відповідних мовах для своєї громади [5].

Батьків слід навчати, як давати дозу левотироксину, причому перший контроль слід здійснити у присутності медичного працівника [3].

Сімейний лікар дитини та місцевий педіатр повинні бути повідомлені по телефону або листом, щоб визначити попередній діагноз та лікування. Група консенсусу радить не інформувати вихователів і педагогів про те, що дитина має ВГ, щоб запобігти «маркуванню» та стигматизації.

Профілактика. Зважаючи на гетерогенність природи ВГ, багато випадків можна попередити, якщо вживати певні заходи ще на антенатальному етапі.

ESPE рекомендує проводити антенатальну діагностику, якщо при плановому ультразвуковому дослідженні плода виявлено зоб; сімейні випадки ВГ унаслідок дисгормоногенезу (частота рецидивів 25\%); якщо є інформація про дефекти генів, які беруть участь у регуляції функції або розвитку ЩЗ. Для оцінки обсягу Щ3 плода рекомендується ультразвукове сканування у терміні вагітності від 20 до 22 тижнів для виявлення гіпертрофії ЩЗ та і1ї потенційної дисфункції у плода. Також рекомендується кордоцентез, а не амніоцентез, як референтний метод для оцінки функції ЩЗ плода. Таке обстеження повинно проводитися, лише якщо розглядається пренатальне втручання. За перебігу вагітності на тлі гіпотиреозу, з метою лікування та профілактики зоба у плода первинним

Скринінг, профілактика та лікування гіпотиреозу плода

Таблиия 4

\begin{tabular}{|c|}
\hline Адекватне споживання йоду повинне бути забезпечене для всіх вагітних жінок (250 мкг на добу) \\
\hline Для жінок з власною або сімейною історією захворювання щЗ концентрації ТТГ та вільногоТ4 \\
у сироватці слід визначати до вагітності, на початку вагітності та під час вагітності \\
\hline При проведенні УЗД у терміни 22 та 32 тижнів вагітності необхідно виміряти діаметр фетальної щЗ та окружність; \\
збільшення понад 95-й процентиль для гестаційного віку слід вважати фетальним тиреоїдним розладом \\
Якщо вагітну жінку лікують левотироксином, слід забезпечити відповідне збільшення дози протягом вагітності \\
\hline Якщо встановлено наявність зоба у плода, слід розглянути можливість проведення кордоцентезу для визначення \\
вмісту вільного Т4 і ТТГ у сироватці крові плода, а також призначати внутрішньоамніотичні ін'єцції левотироксину, \\
якщо діагностовано важкий гіпотиреоз і розвивається прогресуючий гідрамніон \\
\hline
\end{tabular}


підходом має бути лікування вагітної жінки, а не плода. (табл. 4). При еутиреозі у матері та наявності великого зоба у плода натепер розробляються методики лікування шляхом введення левотироксину в амніотичну рідину, але остаточні висновки про співвідношення користь/ризик ще не зроблені [3].

\section{Висновки}

Сучасні стратегії діагностики та лікування ВГ грунтуються на проведенні неонатального скринінгу та ранньому початку лікування. Ці підходи добре відпрацьовані за останні десятиріччя та є подібними в консенсусах різних профільних асоціацій та у вітчизняних протоколах. Основна мета - раннє досягнення еутиреозу у пацієнтів з ВГ та підтримання його протягом усього життя, що забезпечує дитині потенційно нормальний розвиток та попереджує розумову недостатність. Вроджений гіпотиреоз можна попередити у випадках, пов'язаних із йодним дефіцитом, шляхом сапліментації під час вагітності за неможливості отримати достатню кількість йоду з продуктами харчування. Розробляються стратегії профілактики і лікування гіпотиреозу плода. Подальші дослідження спрямовані на вивчення патофізіології цього гетерогенного розладу. Головне питання, яке стоїть перед вченими, чи може знання певного дефекту розвитку або функції ЩЗ поліпшити результати його лікування.

\section{ЛIТЕРАТУРА}

1. МОЗ України. (2006). Протокол надання медичної допомоги дітям за спеціальністю «Дитяча ендокринологія»: наказ МОЗ України № 254 від 27.04.2006 р. Київ:88 с.

2. Jonklaas J, Bianco AC, Bauer AJ, Burman KD et al. (2014, Dec). Guidelines for the treatment of hypothyroidism: prepared by the american thyroid association task force on thyroid hormone replacement. Thyroid. 24(12):1670-751. doi 10.1089/ thy.2014.0028.

3. Leger J, Olivieri A, Donaldson M, Torresani T et al. (2014, Feb). European Society for Paediatric Endocrinology consensus guidelines on screening, diagnosis, and management of congenital hypothyroidism. J Clin Endocrinol Metab. 99(2):363-84. doi 10.1210/jc.2013-189

4. Practical Paediatric Endocrinology in a Limited Resource Setting / Editor M. Zacharin. - Melburne, Australia, 2011. - 320 p.

5. Susan R. Rose, Rosalind S. Brown. (2006, June). Update of Newborn Screening and Therapy for Congenital Hypothyroidism. Pediatrics. 117;6.

6. WHO, UNICEF, and ICCIDD. (2007). Assessment of the lodine Deficiency Disorders and monitoring their elimination. Third edition. Geneva: WHO, WHO/Euro/NUT: 1-98.

7. Zimmermann MB, Boelaert K. (2015). Iodine deficiency and thyroid disorders. Lancet Diabetes Endocrinol. 3(4):286-95.

\section{Сведения об авторах:}

Маменко Марина Евгеньевна - д.мед.н., проф. каф. педиатрии № 2 НМАПО им. П.Л. Шупика. Адрес: г. Киев, ул. Богатырская, 30; тел. (044)-412-16-70.

Статья поступила в редакцию 20.11.2018 г.; принята в печать 12.03.2019 г. 
УдК 616-053.2+612.396.11

\title{
А.Ф. Черник-Булент, Ф.Ф. Гаджиева, Ф.М. Мамедова Редкий случай мукополисахаридоза VI типа: болезнь Марото-Лами (ошибки диагностики)
}

\author{
Азербайджанский медицинский универститет, г. Баку
} SOVREMENNAYA PEDIATRIYA.2019.2(98):53-56; doi 10.15574/SP.2019.98.53

\begin{abstract}
В статье представлены современные сведения о распространённости, этиологии, патогенезе и клинике болезни Марото-Лами (мукополисахаридоз VI типа). Проанализированы основные причины ошибок в диффреренциальной диагностике данного заболевания с другой, сходной по клиническим проявлениям, патологии. На примере собственного наблюдения за ребёнком с болезнью Марото-Лами описаны характерные для нее клинические признаки. Также указано на необходимость медико-генетического консультирования и проведения пренатальной диагностики с целью первичной просилактики данного заболевания.

Ключевые слова: болезни накопления, мукополисахаридозы, болезнь Марото-Лами, дети.
\end{abstract}

\section{A rare case of mucopolysaccharidosis type VI: Maroteaux-Lamy disease (diagnostic errors) \\ A.F. Chernik-Bulent, F.F. Hajiyeva, F.M. Mamedova}

Azerbaijan Medical University, Baku

The article presents modern information about the prevalence, etiology, pathogenesis and the clinical symptoms of the Maroteaux-Lamy disease (mucopolysaccharidosis type VI; MPS VI). It contains a analysis of the main causes of errors in the differential diagnosis of this disease with another pathology similar in presented.clinical manifestations. The example of own observation of a child with Maroteaux-Lamy disease describes the characteristic clinical signs. Also indicated the importance of the medical genetic counseling and prenatal diagnosis for the primary prevention of this disease. Key words: accumulation diseases, mucopolysaccharidosis, Maroteaux-Lamy disease, children/

\section{Рідкісний випадок мукополісахаридозу VI типу: хвороба Марото-Ламі (діагностичні помилки) \\ А.Ф. Черник-Булент, Ф.Ф. Гаджиєва, Ф.М. Мамедова}

Азербайджанський медичний універститет, м. Баку

У статті наведені сучасні відомості щодо поширеності, етіології, патогенезу і клініки хвороби Марото-Ламі (мукополісахаридоз VI типу). Проаналізовані основні причини помилок у диференціальній діагностиці даного захворювання з іншою, зі схожими клінічниим проявами, патологією. На прикладі власного спостереження за дитиною з хворобою Марото-Ламі описані притаманні їй клінічні ознаки. Зазначається необхідність медикогенетичного консультування і проведення пренатальної діагностики з метою первинної профілактики даного захворювання.

Ключові слова: хвороби накопичення, мукополісахаридози, хвороба Марото-Ламі, діти.

$\mathrm{b}^{\mathrm{a}}$ олезни накопления (БН) представляют собой группу редких заболеваний, характеризующихся тяжелыми расстройствами обмена веществ, при которых генетически обусловленные дефекты ряда ферментов вызывают накопление внутри лизосом продуктов жизнедеятельности клеток. В настоящее время известно свыше 50 лизосомных БН [5]. В их структуре выделяют мукополисахаридозы (МПС) - группу метаболических заболеваний соединительной ткани, связанных с нарушением обмена гликозаминогликанов (ГАГ), проявляющихся дефектами костной, хрящевой, соединительной тканей. Согласно Nosology and Classification of Genetic Skeletal Disorders выделяют 7 типов и 12 подтипов МПС [2]. Все МПС, кроме II типа, имеют аутосомно-рецессивный тип наследования.

Мукополисахаридоз VI типа, или синдром Марото-Лами (Maroteaux-Lamy) (МКБ-10: Е 76.2, по каталогу ОМIM № 253200) - по именам впервые описавших его в 1963 г. французских врачей Пьера Марото и Мариса Лами, - лизосомная БН, обусловленная снижением активности фермента $\mathrm{N}$-ацетилгалактозамин4-сульфатазы (4-сульфатаза, арилсульфатаза B, ARSB, EC 3.1.6.12). Ген арилсульфатазы В $(A R S B)$ картирован на длинном плече хромосомы 5, в локусе q14.1. Ген $A R S B$ кодирует фермент арилсульфатазу В, который осуществляет гидролиз сульфатной группы $\mathrm{N}$-ацетилгалактозамин-4-сульфата, дерматансульфата и хондроитин-4-сульфата. Арилсульфатаза В состоит из 492 аминокислот и имеет молекулярную массу 47 кД [1,2].

Синдром Марото-Лами относится к редким (орфанным) заболеваниям. Частота заболеваемости в литературе варьирует от 0,05 до 2,3 на 100000 живорожденных. Как правило, MПC VI типа проявляется только у пациентов c тяжелым дефицитом ферментативной активности арилсульфатазы В (обычно менее $10 \%$ от нижней границы нормы). У носителей одного аномального аллеля сохраняется достаточная активность фермента, позволяющая избежать проявлений заболевания [4]. 
Накопление ГАГ приводит к гибели клеток, тканевому и органному дисбалансу, что и определяет клинический фенотип МПС - начальные признаки различных типов МПС очень схожи между собой, а также с некоторыми другими заболеваниями, что крайне затрудняет правильную раннюю диагностику заболевания. В связи с этим на начальных стадиях развития пациенты с МПС нередко попадают к узкопрофильным специалистам - неврологам, эндокринологам, ревматологам, в подавляющем большинстве случаев исключается комплексный подход к оценке состояния пациента, что приводит к отсрочке постановки правильного диагноза.

Для иллюстрации подобных ошибок в диагностике приводим собственное наблюдение.

\section{Клинический случай}

Больная N, 4 года, поступила в учебно-терапевтическую клинику Азербайджанского медицинского университета в 2018 г с жалобами на задержку роста, скелетные деформации, нарушение походки, невнятную речь, хриплое шумное дыхание.

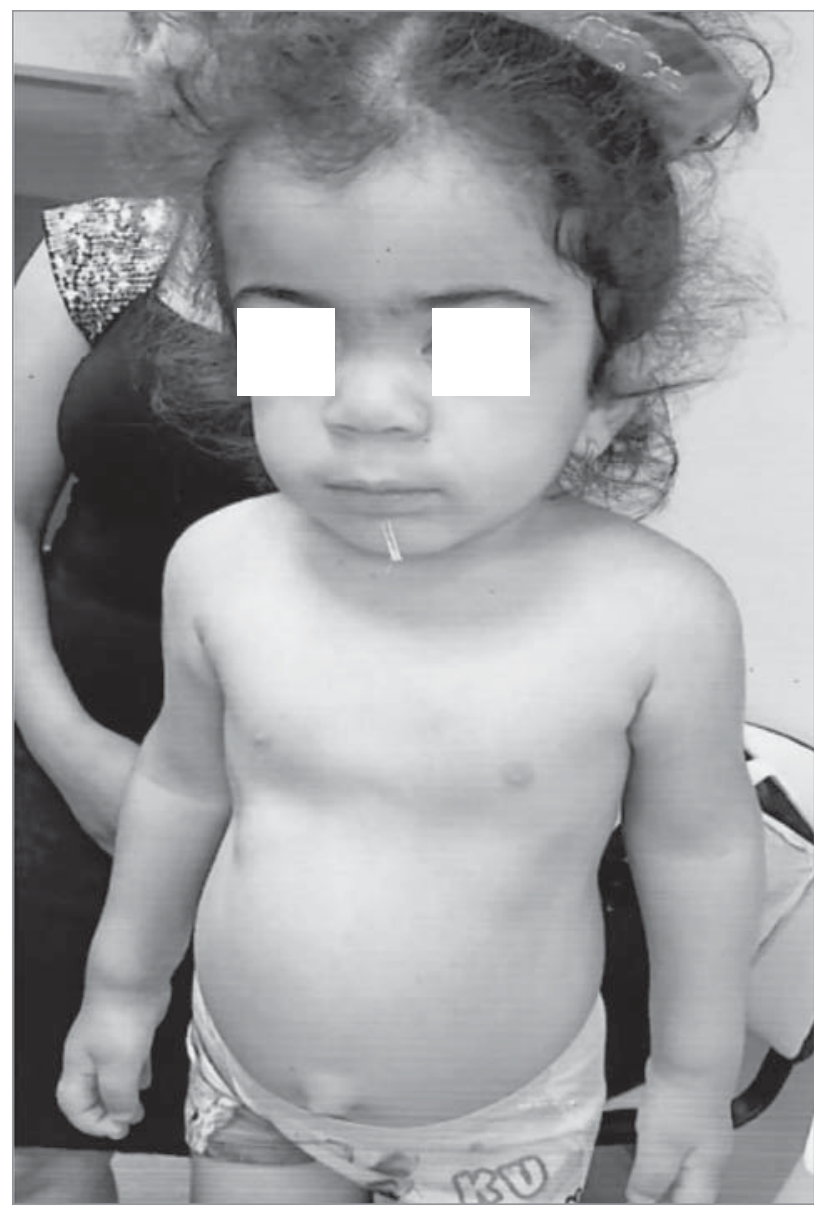

Pис.1. Внешний вид пациентки. Десрормации черепа, грудной клетки, конечностей
Из анамнеза заболевания известно, что в первые 6 месяцев в развитии ребенка особенностей не отмечалось. Однако с 6-месячного возраста начали появляться различные скелетные деформации (изменения черепа, увеличение размеров головы, задержка роста, огрубение черт лица, изменения формы грудной клетки и позвоночника). По этому поводу родители обращались к различным врачам, был поставлен диагноз «Рахит», в связи с чем девочка получала лечения в виде различных препаратов витамина Д, кальция и т.д. Однако эффекта не наблюдалось, клинические признаки к 2-3 летнему возрасту становились более выраженными: присоединились ограничение движений в конечностях (особенно в движениях пальцев кистей), нарушения походки.

Из анамнеза жизни было установлено, что ребенок от I беременности, I родов, данная беременность протекала без патологии, роды в срок (39-40 недель) путем кесарева течения, оценка по шкале Апгар 6-7 баллов. Вес при рождении 3000 г, рост 51 см. Родители паци-

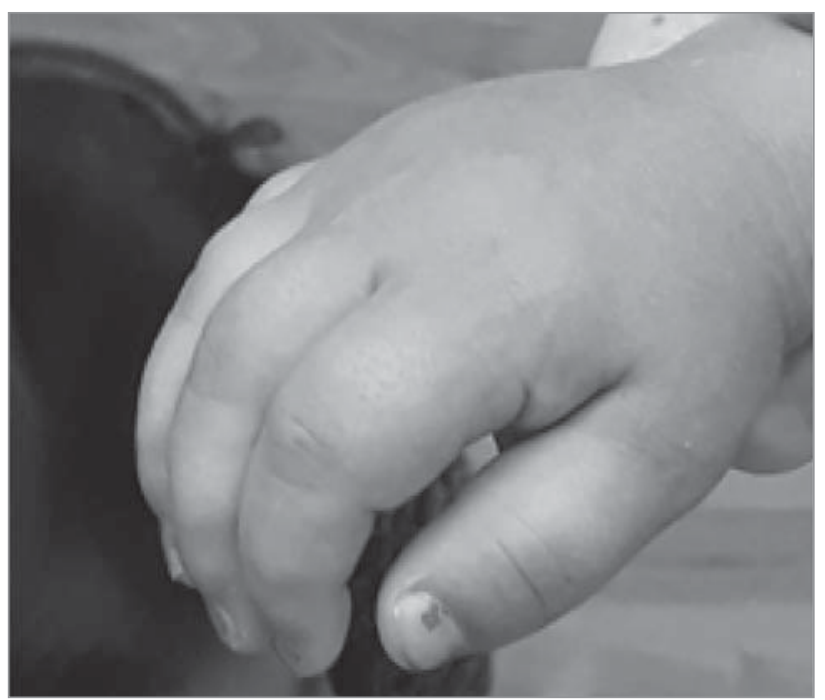

Pис.2. Десрормация кисти (симптом «когтистой лапы»)

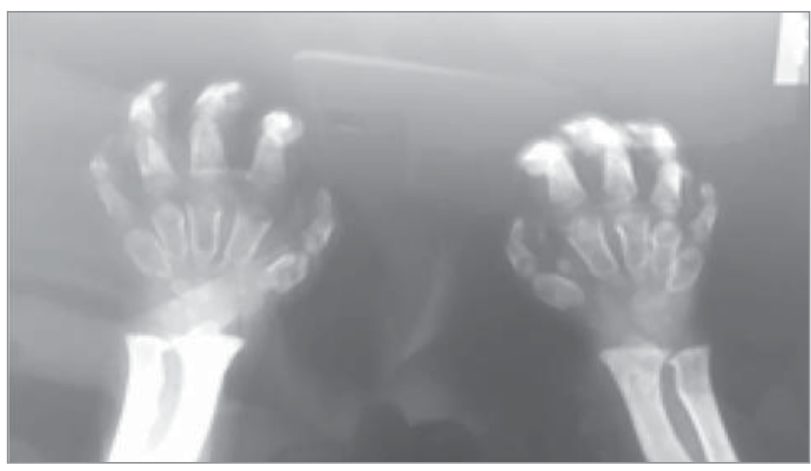

Pис. 3. Рентгенограмма кистей и лучезапястного сустава. Утолщение и десормация дистальных фраланг 
ентки являются родственниками (двоюродные брат и сестра).

Объективный статус. Общее состояние по роду заболевания тяжелое. Самочувствие удовлетворительное. Активна, однако в контакт вступает неохотно. Рост на момент обследования 89,5 см, вес 13,3 кг. Кожные покровы бледные, с землистым оттенком, наблюдается гипертрихоз, более выраженный в поясничной области, подкожная жировая ткань развита слабо.

При осмотре обращают на себя внимание характерные черты лица - широкая запавшая переносица, эпикант, сросшиеся густые брови (синофриз), низкая граница роста волос. Наряду с этим отмечаются долихоцефалия, выраженные лобные и теменные бугры, короткая шея. Грудная клетка деформирована (сдавление с боков, сужение в области нижней апертуры, вдавление в области мечевидного отростка), «веслообразные ребра», кифоз грудного отдела позвоночника. Со стороны верхних конечностей наблюдаются отчетливые контрактуры локтевых суставов (больше справа), уплотнение и гиперплазия в области лучезапястных суставов, сгибательные контрактуры пальцев (симптом «когтистой лапы») (рис. 1, 2). Отмечается вальгусная деформация нижних конечностей, походка нарушена («хождение на цыпочках»).

Дыхание хриплое, однако выраженных признаков дыхательной недостаточности нет, над легкими выслушивается жесткое дыхание. Пульс ритмичный, сердечные тоны приглушены, шумы не выслушиваются. При осмотре ротовой полости обращает на себя внимание большой язык. Живот мягкий, отмечается пупочная грыжа. Гепатоспленомегалия: печень на 3 см выступает из-под реберной дуги, селезенка - на 2 см. Мочеиспускание безболезненное, дефекация 1 раз в сутки. Неврологический статус: отмечается незначительное отставание в психомоторном развитии - ребенок плохо вступает в контакт, некоторая задержка формирования речевых навыков (говорит отдельные слова, речь невнятная). Из данных лабораторно-инструментальных исследований: экскреция с мочой ГАГ 97,3 мг/ммоль (при возрастной норме 7,6-14,4 мг/ммоль), высокий уровень витамина Д в крови - более 100 нг/мл (как следствие неправильного лечения высокими дозами витамина Д в связи с неверным диагнозом до поступления). Рентгенологическое исследование кистей рук показало расширение в поперечнике костей запястья и фаланг пальцев кисти, деформацию в метафизарной зоне (рис. 3).

Пациентке был проведен генетический анализ (CAP's Laboratory Accreditation Program), подтвердивший диагноз МПС VI типа. Исследование было выполнено в соответствии c принципами Хельсинкской Декларации. Протокол исследования был одобрен Локальным этическим комитетом (ЛЭК) всех участвующих учреждений. На проведение исследований было получено информированное согласие родителей ребенка.

Таким образом, основной проблемой постановки диагноза при болезни МаротоЛами является банальное отсутствием знаний о симптомах данной патологии у практических врачей. В литературе имеются описания случаев неблагоприятного исхода болезни, связанных не столько с течением самого заболевания, сколько с ошибками в диагностике и неправильной оценкой возможных осложнений [3].

Учитывая, что прогноз при всех формах MПC VI типа неблагоприятный, т.к. с возрастом прогрессирует необратимый процесс поражения центральной и периферической нервной системы, наиболее перспективным направлением является профилактика. Родителям детей с болезнью Марото-Лами важно проведение медико-генетического консультирования для обеспечения возможности пренатальной и преимплантационной диагностики. Пренатальная диагностика МСП VI типа возможна посредством измерения активности лизосомального фермента арилсульфатазы В в биоптате ворсин хориона на 9-11-й неделе беременности и/или определения спектра ГАГ в амниотической жидкости на 20-22-й неделе гестации. Для семей с известным генотипом более целесообразным является проведение пренатальной ДНК-диагностики патологии. Имеются сведения о находящейся в разработке программе скрининга новорожденных на МПС, которая может быть доступна уже в обозримом будущем. В связи с тем, что в настоящее время уже успешно внедрен метод патогенетического лечения генно-инженерными ферментозамещающими препаратами $[1,4,6]$, ожидается улучшение прогноза заболевания, особенно при легких формах, что может дать надежду при своевременно поставленном правильном диагнозе.

Авторы заявляют об отсутствии конфликта интересов. 


\section{ЛИТЕРАТУРА}

1. Бучинская НВ, Костик ММ, Чикова ИА, Исупова ЕА, Калашникова ОВ, Часнык ВГ, Губин АВ, Рябых СО, Очирова ПВ. (2014). Скелетные проявления при мукополисахаридозах различных типов. Гений ортопедии. 2: 81-90.

2. Воинова ВЮ, Семячкина АН, Воскобоева ЕЮ, Новиков ПВ, Захарова ЕЮ. (2014). Мукополисахаридоз VI типа (синдром Марото-Лами): клинические проявления, диагностика и лечение. Российский вестник перинатологии и педиатрии. Приложение 4: 2-23.

3. Михайлова ЛК, Кулешов АА, Аржакова НИ, Соколова ТВ, Ветрилэ МС, Швачка ИВ, Полякова ОА, Громов ИС. (2017). Синдром Марото-Лами - мукополисахаридоз VI типа: случай из практики (ошибки и осложнения). Гений ортопедии. 23;1:80-84. doi 10.18019/10284427-2017-23-1-80-84.

4. Новиков ПВ, Семячкина АН, Воинова ВЮ, Захарова ЕЮ, Воскобоева ЕЮ. Министерство Здравоохранения Российской Федерации. (2013). Федеральные клинические рекомендации по диагностике и лечению мукополисахаридоза типа VI. Москва: 22.

5. Новиков ПВ. (2014). Лизосомные болезни накопления - актуальная проблема педиатрии и современные возможности патогенетического лечения. Российский вестник перинатологии и педиатрии. 59;4:4-9.

6. Braunlin E, Rosenfeld H, Kampmann C et al. (2013). MPS VI Study Group. Enzyme replacement therapy for mucopolysaccharidosis VI: long-term cardiac effects of galsulfase $\left(\right.$ Naglazyme $\left.^{\oplus}\right)$ therapy. J Inherit Metab Dis. 36;2:385-394.

\section{Сведения об авторах:}

Черник-Булент А.Ф. - кафедра детских болезней, II Азербайджанский Медицинский Универститет, г. Баку, Азербайджан.

Гаджиева Ф.Ф. - кафедра внутренних болезней, I Азербайджанский Медицинский Универститет, г. Баку, Азербайджан.

Мамедова Ф.М. - кафедра детских болезней, II Азербайджанский Медицинский Универститет, г. Баку, Азербайджан.

Статья поступила в редакцию 28.10.2018 г.; принята в печать 09.03.2019 г.

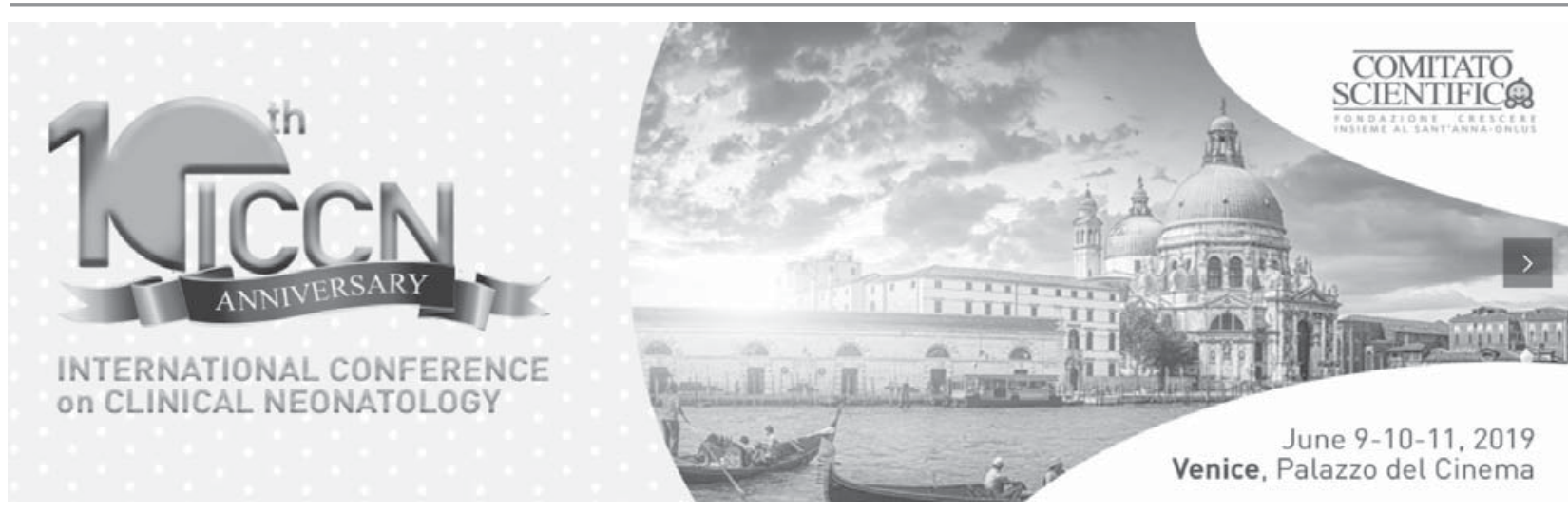

Main topics:

- Hypothermia in preterms: what's new?

- Teamworking in the NICU

- EPO and neuroprotection: an update

- NIDCAP and family-centered care

- Delivery of fetal CHD patients

\section{GOOD REASONS TO ATTEND THIS CONGRESS}

- 10th anniversary celebration - a unique occasion to attend free of charge

- A comprehensive program with the hottest news in neonatology

- An excursus on past 10 years achievements

- Venice - the only place to be in June

- Top science lectures accessible to everyone

More information: https://wrew.mcascientificevents.eu/iccn/ 
УДК $575.224+576.316$

\title{
М.І. Душар', Г.Р. Акопян'1, Г.В. Макух ${ }^{1}$ М.В. Влох', Л.В. Костюченко Синдром «котячого ока» без атрезії ануса, з ампліфікацією генів ADA2 та IL 17RA (клінічний випадок)
}

\author{
'ДУ «Інститут спадкової патології НАМН України», м. Львів, Україна \\ ${ }^{2}$ Західноукраїнський спеціалізований дитячий медичний центр, м. Львів, Україна \\ SOVREMENNAYA PEDIATRIYA.2019.2(98):57-60; doi 10.15574/SP.2019.98.57 \\ Синдром «котячого ока» - рідкісна хромосомна патологія із дуже різноманітною клінічною картиною. Характерними симптомами синдрому \\ $€$ колобома райдужної оболонки ока, преаурикулярні шкірні тяжі або фістули, аномалії ануса, вроджені вади серця та нирок. \\ Мета: уточнення діагнозу у дитини із вродженою вадою серця та стигмами дизембріогенезу. \\ Діагноз грунтується на виявленні додаткової маркерної хромосоми, яка походить з 22 хромосоми. Наведено клінічне спостереження 4-річної дівчинки \\ із синдромом «котячого ока» без атрезії ануса. Діагноз встановлено методом секвенування нового покоління (next generation sequencing, NGS). \\ У регіоні 22q11.1 ідентифіковано чотири копії генів ADA2 та IL17RA. Представлений випадок демонструє кореляцію між генетичною перебудовою \\ та проявами фенотипу. Подвоєння не цілого плеча dup(22)(q11), а лише проксимального регіону довгого плеча 22 хромосоми, де локалізовані \\ дупліковані гени ADA2 та IL17RA, зумовлює такі прояви фенотипу: BBC, преаурикулярні шкірні тяжі, колобому райдужної та судинної оболонок \\ та сітківки ока, затримку мовленнєвого розвитку, імунодефіцит, без атрезії ануса. \\ Ключові слова: синдром «котячого ока», маркерна хромосома, секвенування нового покоління.
}

\section{Cat eye syndrome without anal atresia with the amplification of the ADA2 and IL17RA genes, a description of the clinical case M.I. Dushar', H.R. Akopyan', G.V. Makukh', M.V. Vloch', L.V. Kostyuchenko' \\ 'SI «Institute of Hereditary Pathology, NAMS of Ukraine», Lviv, Ukraine \\ 'Western Ukrainian Specialized Children's Medical Centre, Lviv, Ukraine}

Cat eye syndrome is a rare chromosomal disorder with a highly variable clinical presentation. The characteristic features of CES include ocular coloboma, preauricular pits or tags, anal anomalies, and congenital heart and renal malformations.

Objektive: refinement of the diagnosis in a child with congenital heart disease and stigmata of diesembriogenesis.

The diagnosis is based on the presence of a supernumerary marker chromosome derived from chromosome 22. We present a clinical case description of a 4 year old girl with cat's syndrome without anus atresia. The diagnosis is established by the method next generation sequencing, NGS. The region $22 q 11.1$ identified four copies of $A D A 2$ and IL17RA genes. The presented case demonstrates a correlation between genetic rearrangement and phenotype manifestations. The duplication of the not entire dup (22) (q11) region, but only the proximal part of the chromosome 22 long shoulder, where the duplicated genes ADA2 and IL17RA are localized cause such manifestations of the phenotype: CHD, preauricular skin strands, coloboma of the iris and choroid of retina, delayed speech development, immunodeficiency, without anus atresia.

Key words: Cat eye syndrome, supernumerary marker chromosome, next generation sequencing.

\section{Синдром «кошачьего глаза» без атрезии ануса, с амплификацией генов ADA2 и IL17RA (клинический случай) М.И. Душар', Г.Р. Акопян', Г.В. Макух ${ }^{1}$ М.В. Влох', Л.В. Костюченко \\ 'ГУ «Институт наследственной патологии НАМН Украины», г. Львов, Украина \\ Западноукраинский специализированный детский медицинский центр, г. Львов, Украина}

Синдром «кошачьего глаза» - редкая хромосомная патология с очень разнообразной клинической картиной. Характерными симптомами синдрома являются колобома радужной оболочки глаза, преаурикулярные кожные тяжи или фистулы, аномалии ануса, врожденные пороки сердца и почек. Цель: уточнение диагноза у ребенка с врожденным пороком сердца и стигмами дизэмбриогенеза.

Диагноз основывается на выявлении дополнительной маркерной хромосомы, которая происходит из 22 хромосомы. Описано клиническое наблюдение 4-летней девочки с синдромом «кошачьего глаза» без атрезии ануса. Диагноз установлен методом секвенирования нового поколения (next generation sequencing, NGS). В регионе 22q11.1 идентифицировано четыре копии генов ADA2 и IL 17RA. Представленный случай демонстрирует корреляцию между генетической перестройкой и проявлениями фенотипа. Удвоение не всего плеча dup (22) (q11), а только проксимального региона длинного плеча 22 хромосомы, где локализованы дуплицированные гены ADA2 и IL17RA, обуславливают такие проявления френотипа: ВПС, преаурикулярные кожные тяжи, колобому радужной и сосудистой оболочек и сетчатки глаза, задержку речевого развития, иммунодесицит, без атрезии ануса.

Ключевые слова: синдром «кошачьего глаза», маркерная хромосома, секвенирование нового поколения.

\section{Вступ}

$\mathrm{C}$ индром «котячого ока» (cat eye syndrome, CES, OMIM 115470), відомий також як синдром Шміда-Шраккаро (SchmidFraccaro syndrome), - це рідкісний синдром множинних вроджених вад розвитку, який зустрічається 3 частотою 1:50 000-1:150 000 серед живонароджених $[1,2]$. Синдром був названий «Сat Еуе» через типову офтальмологіч- ну патологію - вертикальну колобому райдужної оболонки ока [3]. CES властива фенотипова мінливість, починаючи від пацієнтів із майже нормальним фенотипом до пацієнтів із важкими вродженими вадами, які становлять загрозу життю [5]. Лише у 41\% хворих відзначається характерна тріада симптомів: колобома райдужної оболонки, атрезія ануса 3 фістулою та преаурикулярні шкірні 
тяжі та/або фістули [6,7]. Колобоми при CES можуть також залучати судинну оболонку та/або сітківку.

Також характерною ознакою CES є черепнолицеві дисморфії (гіпертелоризм, антимонголоїдний розріз очних щілин, мікрогнатія, розщілина піднебіння, низько розташовані вушні мушлі, мікротія та стеноз зовнішнього слухового проходу). Серед інших вроджених вад розвитку синдрому притаманні вроджені вади серця (аномальний сплив легеневих вен та тетрада Фалло), вади нирок (гіпоплазія/агенезія нирки), а також внутрішньопечінкова або позапечінкова біліарна атрезія [1,2]. У літературі повідомляється про гіперінсулінемію, важкий імунодефіцит і серйозні когнітивні порушення [4], вроджену діафрагмальну килу [11].

За даними літератури, у 30\% пацієнтів відзначається розумова відсталість від легкого до помірного ступеня важкості. Немає явної фенотипової різниці між розумово відсталими пацієнтами і пацієнтами без розумової відсталості ОЕС [6,7].

У переважній більшості випадків CES виникає внаслідок додаткової маркерної хромосоми, яка складається із двох ідентичних сегментів 22 хромосоми і являє собою дицентричну хромосому із супутниками з обох сторін та $є$ інвертованою дуплікацією ділянки 22pter $\rightarrow q 11$, яка позначається як inv dup (22) (q11). Присутність подібної маркерной хромосоми в каріотипі означає наявність двох додаткових копій ділянки 22pter $\rightarrow q 11$, тобто часткову тетрасомію 22 хромосоми $[1,8,9]$.

Кілька вроджених вад розвитку, які перекриваютьися із CES, а саме преаурикулярні шкірні тяжі та/або фістули, мікрогнатія, вроджені вади серця можуть виникати внаслідок сімейної транслокації $\mathrm{t}(11 ; 22)$ у синдромі der (22), а в окремих випадках - внаслідок дуплікації інвертованої ділянки $22 q 11$ [8,9]. Проксимальна частина довгого плеча хромосоми 22 (22q11.2) була визнана «гарячим місцем» для перебудови хромосом і містить критичний регіон синдрому CES та Ді Джорджі [10], займає приблизно 2,1 Мб і містить щонайменше 14 генів [13].

Наводимо власне клінічне спостереження випадку CES у дитини

Пробанд жіночої статі, 4-річного віку, від 4-ї вагітності, 4-х термінових фізіологічних пологів, народжений 3 масою 3300 г, довжиною тіла 52 см, за шкалою Апгар 8/8 балів. Батьки соматично здорові, не перебувають у близько спорідненому шлюбі, спадковість не обтяжена. Старші сибси здорові. Після народження у дівчинки діагностовано ВВС - тотальний аномальний дренаж легеневих вен (інтракардіальна форма), вторинний дефект міжпередсердної перегородки, відкрита аортальна протока (ВАП), відкрите овальне вікно (ВОВ), додаткова ліва верхня порожниста вена. При ультрасонографічному дослідженні внутрішніх органів та нейросонографічному дослідженні патології не виявлено. На 7-й день життя у Центрі дитячої кардіології та кардіохірургії м. Києва дитині проведено радикальну корекцію тотального аномального дренажу легеневих вен, закриття вторинного дефекту міжпередсердної перегородки, перев'язки ВАП та додаткової лівої верхньої порожнистої вени.

3 анамнезу відомо, що психомоторний розвиток дитини відповідає віку (голову почала тримати у 3 місяці, самостійно сіла у 7 місяців, самостійно почала ходити в 11 місяців). Часто хворіє на респіраторні інфекції. Знаходиться під динамічним спостереженням у дитячого імунолога. В імунограмі відзначається відсутність імуноглобуліну А ( 0,0 мг / 100 мл при нормі 69,00-382,00), знижений рівень імуноглобуліну G (654,5 мг / 100 мл при нормі 723,00-1682,00), рівень імуноглубуліну М у межах норми. Заключення лікарясурдолога: двостороннє кондуктивне ураження. Займається 3 логопедом 3 приводу загального недорозвинення мовлення III рівня.

Особливості фенотипу - гіпертелоризм, колобома райдужної оболонки правого ока, довгий фільтр, коротка верхня губа, нижче розташовані вушні мушлі, преаурикулярні шкірні тяжі по правій стороні (рис. 1), мікрогнатія.

Офтальмологічний огляд. Гострота зору: OD 0,2/OS 0,2 з корекцією OD sph +1,0 D cyl$2,5 \mathrm{D}$, OS sph +1,5 D cyl - 2,0 D ax 180. Гострота зору з корекцією 0,6 OU.

Рефрактометрія скіаскопічна, авторефрактометрія: змішаний астигматизм обох очей.

Очні щілини рівномірні, рухомість очних яблук обмежена в горизонтальному напрямку. Офтальмоскопічно: OD - передній відрізок не змінений, iris - колобома у нижній частині 3 вертикальним дефектом, при огляді очного дна - у нижньому відділі відсутність судинної оболонки та сітківки. Дана колобома не доходить до макулярної ділянки та диску зорового нерва, які структурно не змінені. OS - передній відрізок, оптичні середовища та задній сегмент відповідають нормі. 
При додатковому обстеженні: fundus report значних розмірів колобома судинної оболонки та сітківки, 3 інтактною макулою та диском зорового нерва. ОСТ - архітектоніка сітківки в макулярній ділянці збережена.

Вроджена вада серця, преаурикулярні шкірні тяжі, колобома райдужної та судинної оболонок ока та сітківки дали підстави запідозрити у дитини CES. 3 метою верифікації діагнозу проведено цитогенетичне дослідження хромосом. Встановлено жіночий каріотип, виявлено маркерну хромосому, яка присутня в кожній проаналізованій клітині (рис. 2). Цитогенетичне дослідження доповнено флуоресцентною гібридизацією in situ (FISH) із застосуванням зондів для критичної ділянки CES (лабораторія медичної генетики спеціалізованого медико-генетичного центру «ОХМАТДИТ», Київ). Виявлено нормальний розподіл сигналів локусів $22 q 11.2$ і $22 q 13.3$ на двох нормальних хромосомах 22. Маркерна хромосома не містила вищевказаних локусів.

Каріотип дитини 47,XX + mar. Ish 22q11.2 (HIRA+), 22q13.3 (ARSA+) (рис. 3).

У подальшій діагностиці використано мультиплексну лігазозалежну ампліфікацію (multiplex ligation-dependent probe amplification, MLPA) із застосуванням комплекту мікроделеційних зондів SALSA MLPA P245-B1 фірми MRC-Holland, MICDEL-1. Дослідження проводилося в Інституті Матері та Дитини (Варшава, Польща). Дане дослідження не виявило незбалансованості геному у критичних регіонах представлених синдромів мікроделеції/дуплікації у застосованому наборі зондів (зокрема 22q11 та 22q13).

Наступним кроком у діагностиці став пакет первинних імунодефіцитів (лабораторія Invitae, США) який включає 102 гени, шляхом секвенування нового покоління (Next-generation sequencing, NGS). Виявлено чотири копії гена $A D A 2$ та IL17RA, які розташовані у регіоні $22 q 11$, що є критичним для CES.

Дослідження виконані відповідно до принципів Гельсінської Декларації. Протокол дослідження ухвалений Локальним етичним комітетом (ЛЕК) всіх зазначених у роботі установ. На проведення досліджень було отримано поінформовану згоду батьків дитини.

\section{Обговорення}

Синдром котячого ока виникає внаслідок додаткової маркерної хромосоми у цитогенетичному дослідженні, яка є меншою за 21 хро-

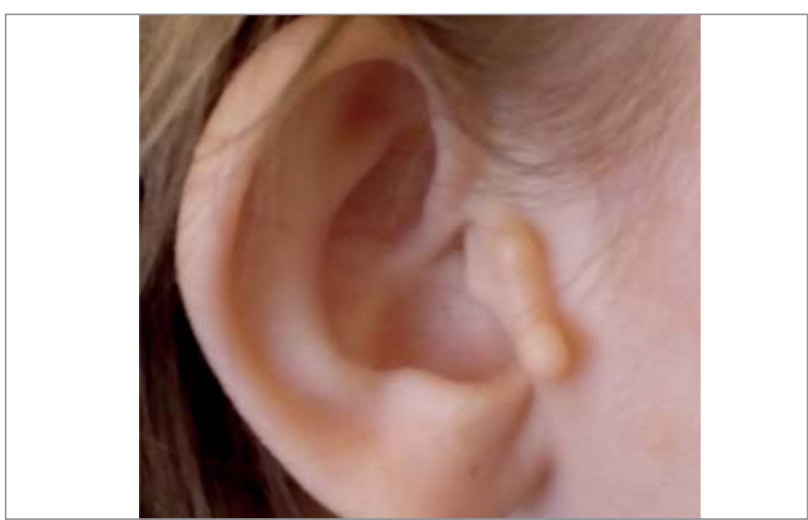

Pис.1. Преаурикулярні фрістули

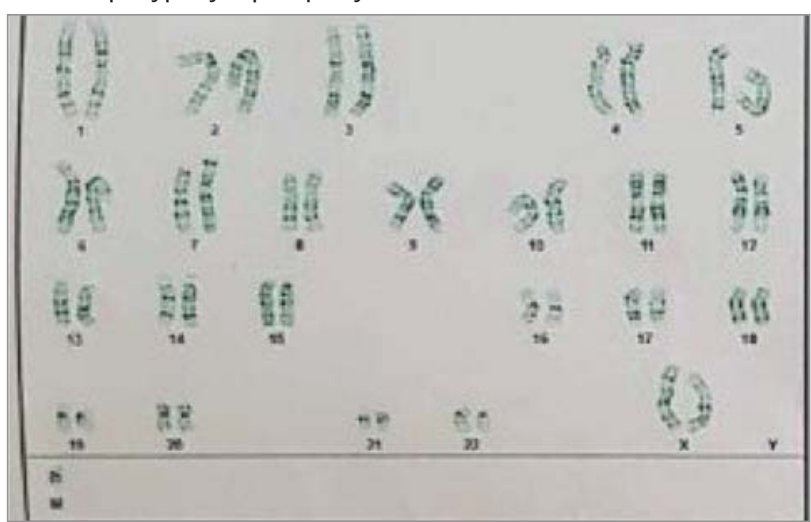

Рис.2. Каріотип пробанда. 47,XX + mar

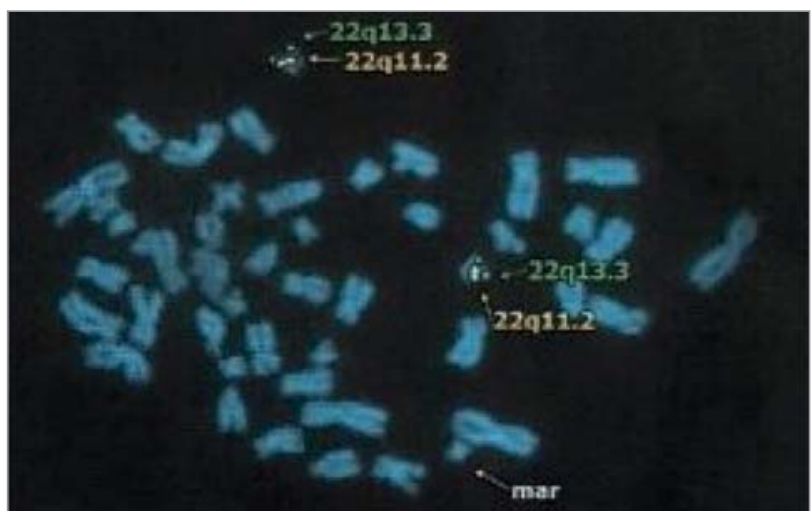

Pис. 3. Флуоресцентна гібридизація in situ (FISH): нормальний розподіл сигналів локусів 22q11 та 22q13.3 на двох хромосомах 22

мосому, має два центромери із супутниками 3 обох сторін та є інвертованою дуплікацією ділянки inv dup(22)(q11) [1]. За даними літератури, з метою ідентифікації 22 хромосоми використовуються флуоресцентна гібридизація in situ (FISH) із застосуванням зондів для критичної ділянки CES, а також мультиплексна лігазозалежна ампліфікація (MLPA) [12,14,15,16]. Проте у нашому клінічному випадку даними дослідженнями не вдалося виявити незбалансованості геному у критичних регіонах $22 q 11$ та 22q13. CES характеризується значною клінічною мінливістю, причина якої і досі залишається невідомою. Ми представили клінічний випадок CES у дитини, у якої спосте- 
рігалися ВВС, преаурикулярні шкірні тяжі, колобома райдужної та судинної оболонок і сітківки ока, двостороннє кондуктивне ураження, затримка мовленнєвого розвитку, імунодефіцит, без атрезї ануса.

У літературі повідомляється про 6 генів (CECR2, SLC25A18, ATP6V1E1, BCL2L13, BID i $M I C A L 3)$, які знаходяться у критичній для CES ділянці (локус 22q11) та можуть бути пов'язані 3 атрезією ануса та преаурикулярними фістулами у CES [13]. Ми описуємо ампліфікацію генів $A D A 2$ та $I L 17 R A$, які теж знаходяться у критичному регіоні $22 q 11$ та можуть бути відповідальними за колобому райдужної та судинної оболонок і сітківки, преаурикулярні шкірні тяжі, тотальний аномальний дренаж легеневих вен, додаткову верхню порожнисту вену при даному синдромі. Гени $I L 17 R A$ та $A D A 2$ розташовані у локусі $22 q 11.1$. Пакет первинних імунодефіцитів містив також інші гени критичного регіону $22 q 11$, саме ген $T B X 1$, що знаходиться в локусі 22q11.21, ген IGLL1 - місце розташування в локусі $22 q 11.23$, проте не відзначено ампліфікації даних генів, що дає право припускати, що маркерна хромосома являє собою інвертовану дуплікацію найбільш проксимального регіону довгого плеча 22 хромосоми (22q11.1). Як нам відомо, це перший клінічний випадок в Україні, коли верифікацію CES проводили за допомогою секвенування нового покоління (NGS) [17].

\section{Висновки}

Наведений випадок CES y дитини демонструє кореляцію між генетичною перебудовою та проявами фенотипу. Подвоєння не цілого плеча $\operatorname{dup}(22)(q 11)$, а лише проксимального регіону довгого плеча 22 хромосоми, де локалізовані дупліковані гени $A D A 2$ та IL17RA зумовлює такі прояви фенотипу: $\mathrm{BBC}$, преаурикулярні шкірні тяжі, колобома райдужної та судинної оболонок та сітківки ока, затримка мовленнєвого розвитку, імунодефіцит, без атрезії ануса.

Автори заявляють про відсутність конфлікmy інтересів.

\section{ЛITEРАТУРА}

1. Alsat EA, Reutter H, Bagci S, Kipfmueller F, Engels H et al. (2018). Congenital diaphragmatic hernia in a case of Cat eye syndrome. Clin Case Rep. 6(9):1786-1790.

2. Bartsch O, Rasi S, Hoffmann K, Blin N. (2005). FISH of supernumerary marker chromosomes (SMCs) identifies six diagnostically relevant intervals on chromosome $22 \mathrm{q}$ and a novel type of bisatellited SMC(22). Eur J Hum Genet. 13(5):592-8.

3. Belangero SI, Bellucco FT, Cernach MC et al. (2009). Interrupted aortic arch type B in A patient with Cat eye syndrome. Arq Bras Cardiol. 92(5): e29.

4. Belangero SI, Pacanaro AN, Bellucco FT et al. (2012). Wide clinical variability in cat eye syndrome patients: four non-related patients and three patients from the same family. Cytogenet Genome Res. 138(1):5-10. doi 10.1159/000341570.

5. Berends MJ, Tan?Sindhunata G, Leegte B, van Essen AJ. (2001). Phenotypic variability of Cat?Eye syndrome. Genet Couns. 12(1):23-34. (PubMed: 11332976).

6. Cat Eye Syndrome. NORD. (2017). http://www.rarediseases.org/raredisease-information/rare-diseases/bylD/1085/viewAbstract.

7. Gentile M, De Sanctis S, Cariola F, Spezzi T, Di Carlo A et al. (2005). FISH approach to determine cat eye syndrome chromosome breakpoints of a patient with cat eye syndrome type II. Eur J Med Genet. 48(1):33-9.

8. Haltrich I, Pico H, Kiss E T?th Z, Karcagi V, Fekete G. (2014). A de novo atypical ring $\mathrm{SSMC}(22)$ characterizet by arry $\mathrm{CGH}$ in a boy with cat-eye syndrome. Mol Cytogenet. 7:37. doi 10.1186/1755-8166-7-37.

9. Heather JM, Chain B. (2016). The sequence of sequencers: The history of sequencing DNA. Genomics. 107(1):1-8. doi 10.1016 / j.ygeno.2015.11.003

10. Jedraszak G, Receveur A, Andrieux J, Mathieu-Dramard M, Copin H et al. (2015). Severe psychomotor delay in a severe presentation of cat-eye syndrome. Case Rep Genet. 2015: 943905 . doi 10.1155 / 2015/943905.

11. Knijnenburg J, van Bever Y, Hulsman L O M et al. (2012). A 600 kb triplication in the cat eye syndrome critical region causes anorectal, renal and preauricular anomalies in a three-generation family. Eur J Hum Genet. 20(9):986-989.

12. Ko JM, Kim JB, Pai KS, Yun JN, Park SJ. (2010). Partial tetrasomy of chromosome 22q11.1 resulting from a supernumerary isodicentric marker chromosome in a boy with cat-eye syndrome. J Korean Med Sci. 25(12):1798-801.

13. McDermid HE, Morrow BE. (2002). Genomic disorders on 22q11. Am J Hum Genet. 70:1077-1088.

14. Meins M, Burfeind P, Motsch S, Trappe R, Bartmus D et al. (2003). Partial trisomy of chromosome 22 resulting from an interstitial duplication of $22 q 11.2$ in a child with typical cat eye syndrome. J Med Genet. 40(5):e62. doi 10.1136/jmg.40.5.e62.

15. Online Mendelian Inheritance in Man, OMIM (TM). (cited 2010 Mar 22). McKusick-Nathans Institute of Genetic Medicine, Johns Hopkins University (Baltimore, MD) and National Centre for Biotechnology Information, National Library of Medicine (Bethesda, MD), 2000. http://www.ncbi.nlm.nih.gov/omim/.

16. Sharma D, Murki S, Pratap T, Vasikarla M. (2014). Cat eye syndrome. BMJ Case Rep. 2014. pii: bcr2014203923.

17. Vorstman JAS, Jalali GR, Rappaport EF et al. (2006). MLPA: a rapid, reliable, and sensitive method for detection and analysis of abnormalities of 22q. Hum Mutat. 27(8):814-21.

\section{Сведения об авторах:}

Душар Мария Ивановна - генетик, мл.н.с. отделения клинической генетики ГУ «Институт наследственной патологии НАМН Украины». Адрес: г. Львов, ул. Лисенко, З1а. Акопян Гаяне Рубеновна - д.мед.н, проф. зам. директора по научной роботе ГУ «Институт наследственной патологии НАМН Украины». Адрес: г. Львов, ул. Лисенко, З1а. Макух Галина Васильевна - д.б.н., зав. молекулярно-генетической лабораторией ГУ «Институт наследственной патологии НАМН Украины». Адрес: г. Львов, ул. Лисенко, 31а. Влох Марта Владимировна - окулист, мл.н.с. отделения клинической генетики ГУ «Институт наследственной патологии НАМН Украины». Адрес: г. Львов, ул. Лисенко, З1а.

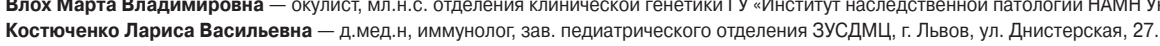
Статья поступила в редакцию 15.11.2018 г; принята в печать 18.03.2019 г. 


\section{Д.С. Хапченкова, С.А. Дубина \\ Синдром Sinding-Larsen-Johansson: обзор литературы и собственное клиническое наблюдение}

Донецкий национальный медицинский университет, г. Лиман, Украина

SOVREMENNAYA PEDIATRIYA.2019.2(98):61-64; doi 10.15574/SP.2019.98.61

В статье представлена информация о вариантах остеохондропатий, встречающихся в детском и подростковом возрасте. Подробно описана остеохондропатия нижнего полюса надколенника, или синдром Sinding-Larsen-Johansson. Показаны возможные причины возникновения, основные звенья патогенеза, клиническая симптоматика, методы инструментальной верификации диагноза, принципы терапии заболеваний. Описано собственное клиническое наблюдение пациента с синдромом Sinding-Larsen-Johansson. Представленный клинический случай характеризуется классическим возрастным началом заболевания и типичными клиническими проявлениями остеохондропатии нижнего полюса надколенника в виде болевого синдрома.

Ключевые слова: надколенник, дети, остеохондропатия, синдром Sinding-Larsen-Johansson.

\section{Sinding-Larsen-Johansson syndrome: a literature review and own clinical case D.S. Khapchenkova, S.A. Dubyna \\ Donetsk National Medical University, Liman, Ukraine}

The article provides information about variants of osteochondropathy, occurring in childhood and adolescence. Osteochondropathy of the lower patella or Sinding-Larsen-Johansson syndrome is described in detail. The possible causes of occurrence, main pathogenesis, clinical symptoms, methods of instrumental verification of diagnosis, principles of treatment of diseases are presented. Own clinical case of the child with Sinding-Larsen-Johansson syndrome was described. The presented clinical case is characterized by the classic age-related onset of the disease and the typical clinical manifestations of osteochondropathy of the lower patella in the form of pain syndrome.

Key words: patella, children, osteochondropathy, Siding-Larsen-Johansson syndrome.

\section{Синдром Sinding-Larsen-Johansson: огляд літератури та власне клінічне спостереження Д.С. Хапченкова, С.О. Дубина}

Донецький національний медичний університет, м. Лиман, Україна

у статті представлена інформація про варіанти остеохондропатій, що зустрічаються у дитячому та підлітковому віці. Детально описана остеохондропатія нижнього полюсу надколінка, або синдром Sinding-Larsen-Johansson. Показані можливі причини виникнення, основні ланки патогенезу, клінічна симптоматика, методи інструментальної вериффікації діагнозу, принципи терапії захворювань. Наведене власне клінічне спостереження дитини із синдромом Sinding-Larsen-Johansson. Даний клінічний випадок характеризується класичним віковим початком захворювання та типовим клінічним проявом остеохондропатії надколінка у вигляді больового синдрому.

Ключові слова: надколінок, діти, остеохондропатії, синдром Sinding-Larsen-Johansson.

\section{Введение}

$\mathrm{H}$ адколенник (лат. - patella) - самая крупная сесамовидная кость скелета человека, располагающаяся в толще сухожилия четырёхглавой мышцы бедра, хорошо пальпируется через кожу, при разогнутом колене легко смещается в стороны, а также вверх и вниз. Верхний край надколенника округлен и носит название - «основание надколенника». Нижний край немного вытянут и образует верхушку надколенника. Передняя поверхность кости шероховатая. Задняя суставная поверхность при помощи вертикально расположенного гребешка разделяется на две неравные части: меньшую - медиальную и большую - латеральную [2].

Сложное анатомическое строение, значительная механическая нагрузка, которой подвергается коленный сустав, незрелость сенсорной иннервации капсульно-связочного аппарата, делают его мишенью для большого количества заболеваний, относящихся к различным разделам медицинской науки [7]. Достаточно частая микротравматизация области коленного сустава в детском и подростковом возрасте значительно затрудняет диагностику заболеваний со скрытой клинической симптоматикой. К таким заболеваниям относятся и остеохондропатии, особенно на ранних стадиях. Ранняя диагностика остеохондропатий и своевременно назначенная терапия в период начальных проявлений позволяют добиться хороших результатов в лечении, благоприятного прогноза и снизить риск возникновения вторичного гонартроза в молодом возрасте [6].

Остеохондропатии - это группа заболеваний, связанных с развитием асептического некроза губчатого вещества различных костей скелета, подверженных значительной механической нагрузке. В области коленного сустава из данной группы в детском и подростковом возрасте встречаются следующие заболевания: болезнь Konig (рассекающий остеохондрит) остеохондропатия суставных поверхностей коленного и пателло-феморального сустава; синдром Osgood-Schlatter - остеохондропатия 
бугристости большеберцовой кости; синдром Sinding-Larsen-Johansson - остеохондропатия нижнего или верхнего полюса надколенника. Рассекающий остеохондрит является внутрисуставным поражением, а синдромы OsgoodSchlatter и Sinding-Larsen-Johansson pacсматриваются как апофизиты (рис.). Следует отметить, что вышеописанные заболевания чаще встречаются у лиц мужского пола, активно занимающихся спортом. На сегодняшний день единого мнения о причинах возникновения данной патологии нет. Существующие теории можно объединить в две основные группы: первая - теория, поддерживающая травматическую, и вторая - ишемическую этиологию [1].

Синдром Sinding-Larsen-Johansson характеризуется болью в переднем отделе коленного сустава и выявляется при рентгенографии фрагментацией нижнего, реже - верхнего полюса надколенника. В 1921 и 1922 годах Sinding-Larsen и Johansson независимо друг от друга описали данную патологию. Заболевание встречается у детей и подростков в возрасте от 10 до 14 лет [9]. Этиология данного заболевания до конца неизвестна. Предполагается, что вследствие значительного функционирования четырёхглавой мышцы в период интенсивного роста возникает разрыв и отделение участка костной ткани от центра оссификации надколенника, что служит причиной развития аваскулярного некроза. В классическом описании синдром Sinding-Larsen-Johansson pacсматривается как апофизит, при котором очаг асептического некроза возникает в костной ткани непосредственно в месте прикрепления сухожилия надколенника. Позднее возникло предположение о локализации патологического очага в проксимальном отделе сухожилия

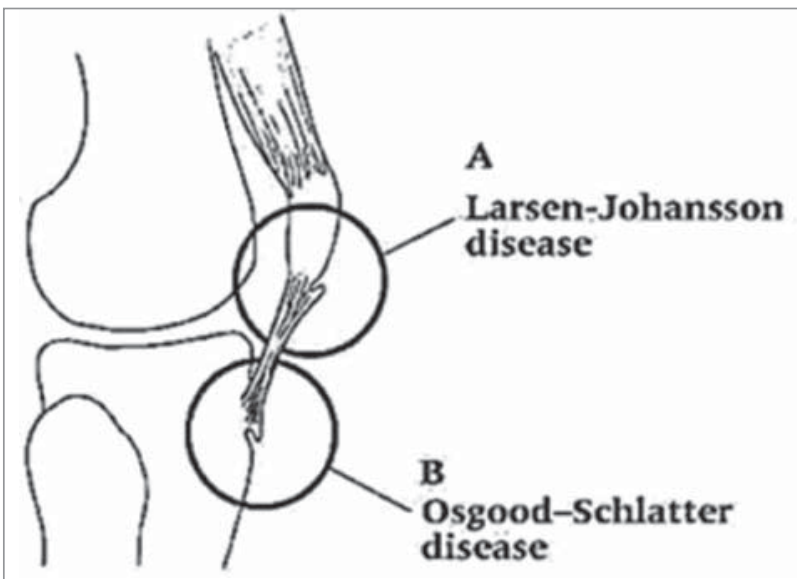

Рис. Локализация патологического процесса при различных остеохондропатиях надколенника, что вызывает кальциноз либо оссификацию данного участка, исходя из чего заболевание рассматривается как тендинит [8]. Синдром Sinding-Larsen-Johansson наблюдается только в детском и подростковом возрасте, причём пик заболеваемости приходится на период полового созревания и обусловлен быстрыми темпами роста.

Клинические проявления заболеваний схожи отсутствием ярких клинических симптомов на начальных стадиях развития, что требует настороженности со стороны педиатров, ревматологов, детских хирургов, ортопедов. Манифестация остеохондропатий области коленного сустава заключается в появлении болевого синдрома. Болевые ощущения возникают при физической нагрузке, при этом характерно отсутствие болезненности в покое, интенсивность боли изначально низкая. Иногда пациенты отмечают лишь дискомфорт в области коленного сустава. Постепенно болевые ощущения становятся более интенсивными и локализованными [3,4].

С дальнейшим развитием патологического процесса болевой синдром может принимать постоянный характер, у больных появляется хромота, констатируется ограничение активных движений в коленном суставе. Вследствие длительно текущего болевого синдрома при данных заболеваниях может развиться гипотрофия четырёхглавой мышцы бедра. К характеристикам болевого синдрома при синдроме Osgood-Schlatter и SindingLarsen-Johansson можно отнести прямую взаимосвязь между появлением боли и сокращением четырёхглавой мышцы бедра (подъём по лестнице, бег). Больные отмечают невозможность встать на поражённое колено из-за резкого усиления боли. При объективном осмотре для рассекающего остеохондрита характерно увеличение объома поражённого сустава вследствие развития синовиита.

Пальпаторно можно диагностировать локальную болезненность, при этом болевая точка будет соответствовать локализации процесса $[4,5]$.

Трудность диагностики данных заболеваний заключается в бессимптомном течении и проявлении только на терминальных стадиях. Длительность болевого синдрома может составлять от нескольких дней до нескольких лет. Нередко заболевание проявляет себя после травмы, здесь необходимо обратить внимание 
на несоответствие травмирующего фактора и развившихся последствий. Такие состояния при отсутствии специальных исследований трактуются как обычные посттравматические состояния (гемартрозы, субхондральные переломы, отрывные переломы и т. п.) [1].

Для синдрома Sinding-Larsen-Johansson характерно появление боли либо ее усиление в области нижнего полюса надколенника при максимальном сгибании в коленном суставе, создании сопротивления при разгибании в коленном суставе.

На рентгенограмме в боковой проекции отмечается узурация передненижнего контура и фрагментация нижнего полюса надколенника. Анализируя рентгенограмму, необходимо помнить о вариантной анатомии надколенника patellae bipartite и patellae tripartite [4,5].

Проведение ультразвукового исследования позволяет диагностировать остеохондропатии области коленного сустава с большой точностью, оценить состояние рентгеннегативных структур коленного сустава [9].

Существуют как консервативные, так и хирургические методы лечения данных заболеваний. Подход к выбору лечения индивидуален и зависит от стадии заболевания, наличия осложнений. Консервативное лечение заключается в снижении активности в коленном суставе: исключаются все движения, вызывающие напряжение квадрицепса и боль. При выраженном болевом синдроме применяется иммобилизация конечности на короткие сроки. При исчезновении симптомов заболевания и положительной динамике в диагностических исследованиях разрешается постепенное увеличение нагрузки на сустав. При отсутствии положительного эффекта в течение трех месяцев показано хирургическое лечение. Для снятия болевого и воспалительного синдрома назначаются анальгетики и нестероидные противовоспалительные препараты. Показаниями к хирургическому лечению являются отрывы апофизов и повторяющиеся обострения на фоне проводимого консервативного лечения [4].

Прогноз при синдроме Sinding-LarsenJohansson благоприятный, симптомы заболевания исчезают в течение года с полным восстановлением функции коленного сустава. Может наблюдаться дискомфорт в области коленного сустава около 2-3-х лет. В редких случаях при отделении костного фрагмента и фиксации его в сухожилии надколенника боль и дискомфорт могут беспокоить пациента достаточно долго [3,5].

\section{Клиническое наблюдение}

Мальчик М., 9 лет, обратился к детскому кардиоревматологу с жалобами на боли в правом коленном суставе, «щелчки» в суставе при подъеме по лестнице и беге. Из анамнеза жизни известно, что ребенок родился от первой беременности, протекавшей без особенностей, от первых срочных родов с массой тела 3500,0 г и ростом при рождении 52 см; оценка по шкале Апгар 8-9 баллов. Влияние стрессовых факторов, токсических веществ, прием медикаментов во время беременности мать отрицает. Ребенок находился на грудном вскармливании до 8 месяцев. Прививки проводились в соответствии с календарем. Рос и развивался соответственно возрасту. Наблюдался педиатром по месту жительства. Перенесенные заболевания: ветряная оспа, простудные заболевания. Аллергологический и семейный анамнез не отягощены. Из анамнеза болезни известно, что впервые болезненные ощущения в области правого коленного сустава ребенок отметил после длительной физической нагрузки (велопрогулки), периодически отмечал появление «хруста» и «щелчков» в правом суставе при подъеме по лестнице. При этом мальчик продолжал посещать спортивную секцию. В покое и ночных болей ребенок не отмечал. Предшествующие простудные заболевания, изменения конфигурации сустава, визуальные признаки воспалительного процесса родители отрицают. Правильного телосложения, удовлетворительного питания. Кожные покровы и видимые слизистые обычной окраски, чистые. Аускультативно в легких везикулярное дыхание, с частотой 16 в минуту. Деятельность сердца ритмичная, тоны ясные, звучные, ЧСС - 80 ударов в минуту. Мануальное исследование правого коленного сустава - отмечалась локальная болезненность в области нижнего полюса надколенника; левый коленный сустав - без патологических изменений. Общий анализ крови, общий анализ мочи, копрограмма - без особенностей. Биохимический анализ крови: билирубин, сахар крови в норме, острофазовые показатели - в пределах нормы; уровень ревматоидного фактора - отрицательный. ЭКГ: ритм синусовый, ЧСС 80 ударов в минуту. Вертикальное положение электрической оси сердца. При проведении эхокардиографического исследования: миокард не утолщен. Дополнительная хорда в полости левого желудочка. Сократительная способность 
удовлетворительная. Рентгенограмма правого коленного сустава в боковой проекции - узурация передненижнего контура и фрагментация нижнего полюса надколенника. Ультразвуковое исследование правого коленного сустава контур надколенника в нижнем полюсе в месте прикрепления собственной связки надколенника неровный, фрагментирован, имеет гиперэхогенные фрагменты 3,9 мм, 3,1 мм, 3,5 мм, 4,6 мм, 7,0 мм. Сухожилие четырехглавой мышцы не изменено. В боковых, медиальных и латеральных проекциях признаков экссудата, нарушения целостности структур нет. Кисты Бейкера отсутствуют. Консультирован ортопедом - остеохондропатия нижнего полюса надколенника (синдром Sinding-Larsen-Johansson). Рекомендовано ограничение физической активности, щадящий режим правого коленного сустава, противовоспалительная терапия коротким курсом, хондропротекторы, препарат L-карнитина, наблюдение в динамике.
Исследование было выполнено в соответствии с принципами Хельсинкской Декларации. Протокол исследования был одобрен Локальным этическим комитетом учреждения. На проведение исследований было получено информированное согласие родителей.

\section{Обсуждение и выводы}

Описанный клинический случай характеризуется классическим возрастным манифестом и типичными клиническими проявлениями остеохондропатии нижнего полюса надколенника в виде болевого синдрома на фоне физической нагрузки, инструментальными изменениями, присущими вышеописанной патологии. Педиатрам, семейным врачам, ревматологам, ортопедам необходимо знать симптомы обсуждаемой патологии для ранней диагностики и своевременного начала коррекционного лечения данного заболевания.

\section{Конфликт интересов отсутствует.}

\section{ЛИТЕРАТУРА}

1. Абальмасова ЕА. (1981). Остеохондропатии. Детская артрология. Москва: Медицина:284-303

ной ткани. Руководство для врачей. Книга 2. Москва: Бином: 480.

2. Ковешников ВГ. (2005). Анатомия человека. В трех томах. Том 1. Луганск: Изд-во Шико ТОВ Виртуальная реальность:328.

3. Кожевников АН, Поздеева МА, Конев НА, Никитин МС, Брянская АИ, Прокопович ЕВ, Афоничев КА, Новик ГА. (2018). Боли в суставах у детей. Лечащий врач. 4:50-55

4. Прокопьев НЯ. (2017). Заболевания коленного сустава у юных физкультурников и спортсменов. Научно-спортивный вестник Урала и Сибири.3(15):33-44.

5. Стрюк РИ, Ермолина ЛМ. (2012). Ревматические болезни. Болезни суставов и диффузные заболевания соединитель-

6. Aichroth PA. (1971). Osteochondritis dissecans of the knee. A clinical survey. J Bone Joint Surg. 53:440-7.

7. Bird HA. (2005). Joint hypermobility in children. Rheumatology. 44(6);1:703-704. doi 10.1093/rheumatology/keh639.

8. Carr CJ, Hanly S, Griffin J, Gibney R. (2001). Sonography of the Patellar Tendon and Adjacent Structures in Pediatric and Adult Patients. AJR. 176:1535-1359.

9. Medlar RC, Lyne, ED. (1978). Sinding-Larsen-Johansson disease. Its etiology and natural history. J Bone Joint Surg Am. 49(3):477-80.

\section{Сведения об авторах:}

Хапченкова Дарья Сергеевна - врач-педиатр, детский кардиоревматолог, ассистент каф. анатомии человека Донецкого НмУ. Адрес: г. Лиман, ул. Привокзальная, 27. Дубина Сергей Александрович - к.мед.н, доц., зав. каф. анатомии человека Донецкого НМУ. Адрес: г. Лиман, ул. Привокзальная, 27.

Статья поступила в редакцию 03.11.2018 г.; принята в печать 11.03.2019 г. 


\section{С.О. Крамарьов, Л.В. Закордонець}

\section{Застосування розчинів для оральної регідратації у дітей. Методичні рекомендації}

Національний медичний університет імені О.О. Богомольця, м. Київ, Україна

SOVREMENNAYA PEDIATRIYA.2019.2(98):65-74

гідно з визначенням ВООЗ, дегідратація

Забо зневоднення, - це надмірна втрата рідини організмом. Дегідратація організму розвивається при обмеженому надходженні рідини, при збільшеному іiї виведенні, а також при одночасній дії цих двох факторів.

Виділяють наступні варіанти зневоднення:

1. Клітинне гіперосмолярне зневоднення (водяне виснаження, справжня дегідратація)

Причиною гіперосмолярного зневоднення можуть бути: надмірні втрати рідини через нирки (поліурія) при нецукровому та цукровому діабеті, тривале застосування осмотичних діуретиків, хронічна ниркова недостатність 3 порушенням концентраційної функції нирок, гіпервентиляційний синдром, опіки великої поверхні тіла, неправильна корекція водного дефіциту гіперосмолярними рідинами або прийом через рот солей натрію.

2. Позаклітинне ізо- та гіпоосмолярне зневоднення

Ізоосмолярне зневоднення виникає при еквівалентних втратах води та солей, при цьому втрачається рідина, за вмістом електролітів та осмолярності близька до аналогічних показників плазми крові здорової людини.

Позаниркові втрати солевмісної рідини можуть здійснюватися через шлунковокишковий тракт (блювота, діарея), промивання шлунка та кишечника безсольовими розчинами, значне потовиділення. Через нирки значна кількість води та солей втрачається при зниженні продукції альдостерону та глюкокортикоїдів (хвороба Аддісона, надниркова недостатність, гіпофункція АКТГ), при поліуричній стадії ХНН. Ці втрати призводять до сольового та водного дефіциту одночасно.
Гіпоосмолярне зневоднення виникає в тих випадках, коли втрати солей (особливо хлориду натрію) переважають над втратами води. Цей варіант зневоднення можливий при втратах електролітів через післяопераційні нориці (фістули) верхніх відділів тонкого кишечника у хворих, що оперовані з приводу патології жовчовивідних шляхів та підшлункової залози, дванадцятипалої кишки, травматичних ушкоджень тонкого кишечника.

Суттєві втрати електролітів можуть бути при захворюваннях підшлункової залози, жовчовивідних шляхів або кишечника, що супроводжуються хронічними проносами.

3. Загальне або тотальне зневоднення, яке виникає як вихід першого або другого варіанту дегідратацій

Зміни водно-електролітного балансу мають зв'язок з обмінними процесами. Потреба у рідині та електролітах прямо пропорційна швидкості метаболізму, який посилюється при інфекційних захворюваннях. Так, для заміщення фізіологічних втрат на кожні 100 ккал потрібно введення 115 ммоль води, 3 ммоль натрію та 2 ммоль калію. Враховуючи частку ендогенно утвореної води, 100 ккал відповідають 100 мл введеної ззовні рідини. За нормальних умов втрати рідини розподіляються наступним чином: сеча $50 \%$, випаровування зі шкіри - 30\%, випаровування через легені - 15\%, з фекаліями - до $5 \%$.

У таблиці 1 наведені шляхи та кількісні показники втрат рідини та основних електролітів у нормі та при патології.

Підвищення температури тіла супроводжується збільшенням потреб у рідині на 10 мл/кг на кожен $1^{\circ} \mathrm{C}$. При наявності тахіпное втрати рідини 3 перспірацією зростають на 5-20 мл/кг/добу. У пацієнтів зі значним

Втрати води та електролітів на кожні 100 ккал (Nelson Textbook, 18th ed. 2007) [21]

Таблиия 1

\begin{tabular}{|l|c|c|c|c|c|c|}
\hline \multirow{2}{*}{ Шлях втрат } & \multicolumn{3}{|c|}{ Звичайні втрати } & \multicolumn{3}{c|}{ Патологічні стани } \\
\cline { 2 - 7 } & Вода, мл & Натрій, ммоль & Калій, ммоль & Вода, мл & Натрій, ммоль & Калій, ммоль \\
\hline Легені & 15 & 0 & 0 & $10-60$ & 0 & 0 \\
\hline Шкіра & 40 & 0,1 & 0,2 & $20-100$ & $0,1-3,0$ & $0,2-1,5$ \\
\hline Кал & 5 & 0,1 & 0,2 & $0-50$ & $0,1-4,0$ & $0,2-3,0$ \\
\hline Сеча & 65 & 3,0 & 2,0 & $0-400$ & $0-30,0$ & $0-30,0$ \\
\hline
\end{tabular}


потовиділенням на 5-25 мл/кг/добу збільшується випаровування 3 поверхні шкіри. Блювання супроводжується втратами близько 20 мл/кг/добу, діарея - 25-75 мл/кг/добу.

Діти, особливо раннього віку, більш чутливі до втрат рідини, ніж дорослі. Це пов'язано з відносно вищим рівнем основного обміну, більшою поверхнею тіла відносно маси, більшим вмістом води (понад 70\% маси тіла у немовлят, близько 65\% в ранньому віці та $60 \%$ у дорослих). Сечовиділення також має залежність від віку: нормальний діурез у дітей до 1 року життя складає 2 мл/кг/год, у дітей раннього віку - 1,5 мл/кг/год, у дітей старшого віку - 1 мл/кг/год, у дорослих 0,5 мл/кг/год. У дітей відносно вищі, порівняно 3 дорослими, перспіраційні втрати води: 0,5 мл/кг маси тіла за годину у новонароджених, 0,4 мл/кг/день у старших дітей та 0,3 мл/кг/день у підлітків.

Прояви дегідратації розцінюються як показник тяжкості і є одним з показань до госпіталізації хворих. Найбільш оптимальним засобом ліквідації втраченої води та електролітів є вживання розчинів для оральної регідратації (ОРС).

Незважаючи на простоту і фізіологічність, оральна регідратація - порівняно новий метод лікування, який отримав поширення тільки в другій половині XX століття. Перший розчин для оральної регідратації був розроблений не для лікування хворих, а для відновлення функціонального стану спортсменів після тривалих виснажливих змагань. У 1960-х рр. скандинавські вчені почали вивчати механізми розщеплення глікогену у м'язах при тривалих фізичних навантаженнях. Науково-дослідна група вчених виявила, що спортсмени втрачали до 8,2 кг маси тіла за три години роботи на полі і що від 90 до 95\% від цієї маси становила вода. При цьому обсяг плазми крові знижувався на 7\%, а обсяг крові - на 5\%, також з організму вимивався натрій і хлор. За результатами тривалих досліджень в 1965 році в лабораторії Університету Флориди група дослідників розробили склад регідратаційного напою для футбольної команди університету. Після позитивного досвіду застосування засобів для оральної регідратації у здорових людей їі стали вивчати як метод терапії при різних захворюваннях.

ОРС для лікування зневоднення при інфекційних діареях була створена в Міжнародному дослідницькому центрі з вивчення діарейних захворювань в Бангладеш наприкінці 60-х років XX століття для лікування холери. У наступні роки D. Mahalanabis показав ефективність OPC під час спалаху холери серед біженців в Бангладеш в 1971-1972 pp. De i співавт. в 1974 році і Chatterjee і співавт. в 1978 р. переконливо показали ефективність ОРС у дітей з діареєю, в тому числі і при холері. У 1979 році D. Pizarrow i співавт. показали, що оральна регідратація ефективна і безпечна навіть у періоді народжуваності. Грунтуючись на цих даних, Всесвітня організація охорони здоров'я (ВОО3) в 1978 році впровадила в практику лікування зневоднення при діарейних захворюваннях ОРС.

ВООЗ і ЮНІСЕФ спочатку рекомендували уніфіковану формулу розчину для оральної регідратації для лікування зневоднення. Протягом 25 років при діареї застосовувався розчин наступного складу:

- натрію - 90 ммоль/л;

- калію - 20 ммоль/л;

- хлориду - 80 ммоль/л;

- гідробікарбонату - 30 ммоль/л;

- глюкози - 111 ммоль/л;

- осмолярність - 311 мОсм/л.

Було доведено, що розчин ВООЗ ефективно усуває зневоднення, метаболічний ацидоз та рівень смертності при діарейних захворюваннях. Однак головним недоліком цього розчину є те, що він не впливає на частоту та тривалість неоформлених випорожнень i може викликати гіпернатріємію. Склад цього розчину в основному грунтується на втратах рідини та солей у хворих на холеру. Втрати натрію при холері складають 90-120 ммоль/л, а при більшості гострих кишкових інфекцій втрати натрію становлять не більше 50-60 ммоль/л. Співвідношення концентрації електролітів і глюкози в розчинах для оральної регідратації має сприяти резробції води не тільки в кишечнику, але і ниркових канальцях. Оптимальне всмоктування води і електролітів, як в кишечнику, так і в ниркових канальцях, відбувається при співвідношенні натрій/глюкоза 60-70 ммоль/л - 90-120 ммоль/л.

3 огляду на викладене, були створені і випробувані гіпоосмолярні розчини (з осмолярністю $\leq 270 \mathrm{мOсм/л).} \mathrm{Дослідження} 3$ вивчення їх ефективності виявили перевагу гіпоосмолярних розчинів для оральної регідратації над ізотонічними і гіперосмолярними розчинами.

При застосуванні гіпоосмолярного розчину об'єм випорожнень зменшується на 58\%, три- 
валість діареї скорочується на 55\%, знижується ризик розвитку гіпернатріємії, порівняно 3 терапією стандартними розчинами.

Проведений метааналіз 11 рандомізованих досліджень показав, що зниження осмолярності розчинів для оральної регідратації не тільки знижує об'єм випорожнень при діарейних захворюваннях, але і на 33\% зменшує кількість незапланованих внутрішньовенних інфузій, порівняно зі стандартним розчином ВООЗ. Крім цього, гіпоосмолярний розчин також дозволяє знизити частоту виникнення блювоти на $30 \%$ та частоту випорожнень на $20 \%$.

Враховуючи зазначене, в травні 2004 року ВООЗ та Дитячий фонд ООН (ЮНІСЕФ) видали нові рекомендації по контролю за діареєю у дітей, в яких було обгрунтовано застосування гіпоосмолярних розчинів $(245 \mathrm{mOcм} / л)$ 3 низькою концентрацією хлориду натрію (до 75 ммоль/л) та глюкози (до 75 ммоль/л).

На сьогоднішній день ВООЗ рекомендуе наступний склад розчинів для оральної регідратації:

- натрію - 75 ммоль/л (натрію хлорид 2,6 г/л);

- калію - 20 ммоль/л (калію хлорид 1,5 г/л);

- глюкози - 75 ммоль/л (глюкоза 13,5 г/л);

- цитрату натрію - 10 ммоль/л (2,9 г/л);

- осмолярність - 245 мОсм/л (3).

Європейське товариство дитячих гастроентерологів та дієтологів (ESPGAN) рекомендує подібний склад розчинів зі зниженою осмолярністю:

- натрію - 60 ммоль/л;

- калію - 20 ммоль/л;

- глюкози - 74-111 ммоль/л;

- цитрату натрію - 10 ммоль/л;

- осмолярність - 200-250 мОсм/л [8].
В Україні на фармацевтичному ринку $е$ декілька розчинів для оральної регідратації, що відповідають сучасним вимогам. Серед них в якості прикладу можна навести розчин під комерційною назвою Регідрон Оптім. Склад цього розчину повністю відповідає складу, що рекомендований ВООЗ: натрій 75 ммоль/л, калій - 20 ммоль/л, глюкоза 75 ммоль/л, цитрата натрію - 10 ммоль/л $(2,9$ г/л), осмолярність -245 мОсм/л.

Для проведення адекватної регідратації необхідно визначити ступінь зневоднення дитини до початку терапії. Найкращим показником зневоднення є розрахунок відсотка втрати маси тіла дитини. На жаль, дані про масу дитини до початку захворювання не завжди доступні лікарю і батькам, тому на практиці доводиться орієнтуватися на клінічні дані. Для цього існують різні методики, але у світі останнім часом користуються трьома шкалами для визначення ступеня дегідратації: клінічна шкала дегідратації (CDS), шкала ВОО3 та шкала Gorelick для дітей від 1 місяця до 5 років життя (табл. 2,3,4). За шкалою CDS 0 балів вказують на відсутність дегідратації, сума балів від 1 до 4 відповідає легкому ступеню дегідратації, 5-8 балів - дегідратації середнього та тяжкого ступеня.

Шкала Gorelick може оцінюватись за 4-а першими показниками, наведеними в таблиці 4, або за 10-а показниками. При оцінці за 4-а показниками наявність $\leq 2$ клінічних симптомів вказує на втрату $\leq 5 \%$ маси тіла. Наявність $\leq 3$ клінічних симптомів вказує на втрату $\leq 10 \%$ маси тіла. Якщо оцінювати всі 10 симптомів, то наявність $\leq 3$ з них вказує на втрату $\leq 5 \%$ маси тіла, а наявність $\leq 7$ клінічних ознак вказує на втрату $\leq 10 \%$ маси тіла.

Таблиия 2

Клінічна шкала дегідратації (CDS) для дітей

\begin{tabular}{|c|c|c|c|}
\hline \multirow{2}{*}{ Ознака } & \multicolumn{3}{|c|}{ Бали } \\
\hline & 0 & 1 & 2 \\
\hline Загальний вигляд & нормальний & $\begin{array}{l}\text { спрага, неспокій або млявість } \\
\text { зі збудженням при дотику }\end{array}$ & $\begin{array}{c}\text { сонливість, холодні та спітнілі кінцівки } \\
\pm \text { коматозний стан }\end{array}$ \\
\hline О4і & нормальні & злегка запалі & сильно запалі \\
\hline Слизові оболонки & вологі & липкі & cyxi \\
\hline Сльози & без змін & знижена кількість & відсутні \\
\hline
\end{tabular}

Шкала В003 для визначення дегідратації (WHO Severe Scale) (враховується 2 та більше симптоми)

Таблиия 3

\begin{tabular}{|l|c|c|c|}
\hline \multicolumn{1}{|c|}{ Ознака } & А & В & С \\
\hline Стан & задовільний, активний & неспокійний, збуджений & сонливий або без свідомості \\
\hline Очі & нормальні & запалі & запалі \\
\hline Спрага & відсутня & турбує, п'є жадібно & п'є мало або не може \\
\hline Шкірна складка & швидко розправляється & повільно розправляється & дуже повільно розправляється (>2с) \\
\hline Відсоток втрати маси тіла & $<5 \%$ & $5-10 \%$ & $>10 \%$ \\
\hline Ступінь дегідратації & відсутня & помірна & значна \\
\hline
\end{tabular}


Шкала Gorelick для визначення дегідратації у дітей від 1 місяця до 5 років життя

Таблиия 4

\begin{tabular}{|l|c|c|}
\hline \multicolumn{1}{|c|}{ Ознака } & Дегідратація відсутня або мінімальна & Дегідратація від помірної до тяжкої \\
\hline Загальний вигляд & активний & неспокійний, сонливий або без свідомості \\
\hline Час наповнення капілярів & нормальний & збільшений або мінімальний \\
\hline Сльози & присутні & відсутні \\
\hline Слизові оболонки & вологі & сухі, дуже сухі \\
\hline Очі & нормальні & запалі або сильно запалі \\
\hline Дихання & нормальне & глибоке, глибоке та швидке \\
\hline Пульс & нормальний & ниткоподібний, слабкий або не визначається \\
\hline Шкірна складка (тургор) & швидко розправляється & повільно розправляється чи >2с \\
\hline ЧСС & нормальна & тахікардія \\
\hline Діурез & нормальний & олігурія або анурія \\
\hline
\end{tabular}

Значимість симптомів дегідратації в клінічній практиці

Таблиия 5

\begin{tabular}{|l|c|c|}
\hline \multicolumn{1}{|c|}{ Симптоми } & Значимість для дегідратації І ступеня & Значимість для дегідратації II ступеня \\
\hline Збільшення часу капілярної перфузії & мінімальна & оптимальна \\
\hline Зниження тургору шкіри & мінімальна & оптимальна \\
\hline Сухість слизових оболонок & оптимальна & висока \\
\hline Порушення дихання & мінімальна & оптимальна \\
\hline Запалі очі & мінімальна & оптимальна/висока \\
\hline Зміни загального стану & мінімальна & оптимальна \\
\hline Холодні кінцівки & оптимальна & висока \\
\hline Відсутність сліз & мінімальна & оптимальна \\
\hline Тахікардія & мінімальна & оптимальна \\
\hline Слабкий пульс & мінімальна & оптимальна \\
\hline Запале тім'ячко & мінімальна & оптимальна \\
\hline
\end{tabular}

Незважаючи на різноманіття шкал, жодна 3 них не показала адекватну чутливість, специфічність і надійність для виявлення дегідратації і прогнозування важкого перебігу захворювання у дітей раннього віку. Наприклад, при обстеженні 124 дітей віком від 1 місяця до 5 років життя з гострою діареєю шкала CDS показала обмежену діагностичну значимість лише при тяжкій дегідратації. А шкали ВООЗ та Gorelick не допомагали в оцінці будь-якого ступеня зневоднення. В таблиці 5 наведена значимість окремих клінічних симптомів дегідратації. Дані лабораторних досліджень також суттєво не допомагають при визначенні ступеня дегідратації. При ГКІ у дітей приблизно в 80\% випадків розвивається ізотонічний тип зневоднення, який супроводжується пропорційною втратою рідини й електролітів, в першу чергу натрію. При цьому не спостерігаються зміни осмотичного тиску води у внутрішньоклітинному і позаклітинному просторах, що ускладнює його визначення лабораторними методами. Однак дані електролітного складу крові та кислотно-лужного складу слід враховувати при первинному обстеженні дітей 3 дегідратацією та в ході лікування.

Якщо у дитини з діареєю відсутні ознаки зневоднення, то основною метою регідратацій- ної терапії є його профілактика. Для цього вже 3 перших годин захворювання дитині дають пити підвищену кількість рідини:

- дітям молодше 2 років - по 50-100 мл після кожного випорожнення;

- дітям від 2 до 10 років - по 100-200 мл після кожного випорожнення;

- дітям старше 10 років - стільки рідини, скільки вони бажають випити.

Оральну регідратацію за наявності ознак зневоднення легкого та середнього ступеня проводять у два етапи.

- Перший етап - за перші 4-6 години намагаються усунути водносольовий дефіцит. На цьому етапі призначають 30-50 мл/кг при дегідратації I ступеня і 80-100 мл/кг при дегідратації II ступеня.

Критеріями ефективності першого етапу регідратації є: зникнення спраги, підвищення тургору тканин, зволоження слизових оболонок, збільшення діурезу, зникнення ознак порушення мікроциркуляції.

- Другій етап - підтримуюча регідратація, яка проводиться в залежності від поточних втрат рідини. Орієнтовний обсяг розчину для підтримуючої регідратації - 


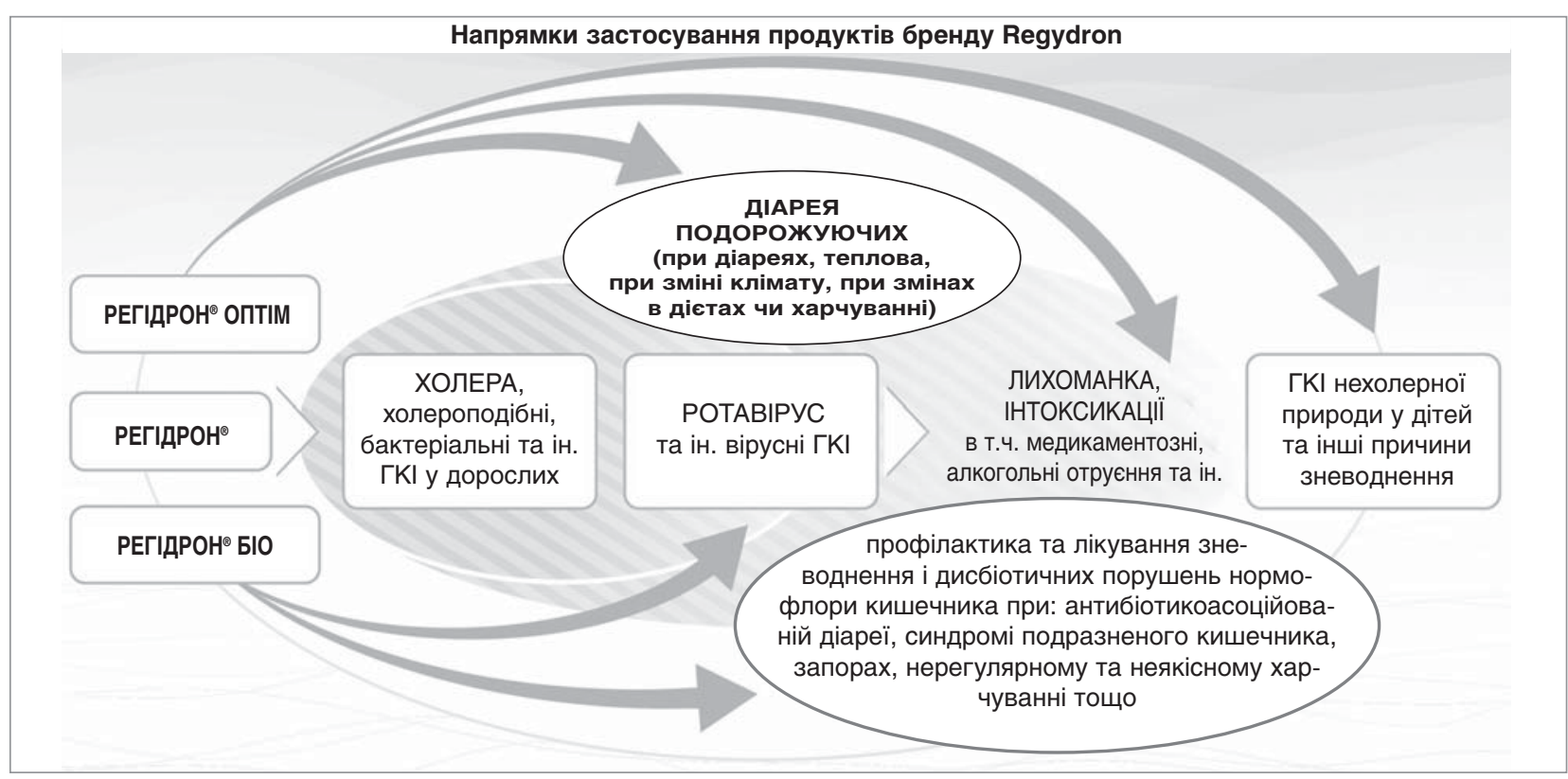

50-100 мл або 10 мл/кг після кожного випорожнення.

Застосування розчинів для оральної регідратації при лікуванні діареї

Діарея є другою за значимістю причиною смерті дітей у віці до п'яти років, від якої щорічно помирає 525 тисяч дітей. У світі щорічно реєструється близько 1,7 мільярда випадків діареї у дітей.

Оральна регідратація в теперішній час використовується в різних країнах світу у $99 \%$ дітей, хворих на діарею. Своєчасна та адекватна регідратаційна терапія є першочерговою та найбільш важливою складовою частиною в лікуванні діареї як у дітей, так і у дорослих. Раннє використання адекватної регідратаційної терапії.

Застосування ОРС в якості основного методу боротьби із зневодненням при діареї дало можливість знизити смертність дітей у віці до 5 років при діарейних захворюваннях у всьому світі на 3 млн щорічно. За даними мета-аналізу 157 досліджень встановлено, що застосування оральної регідратації дозволяє попередити 93\%

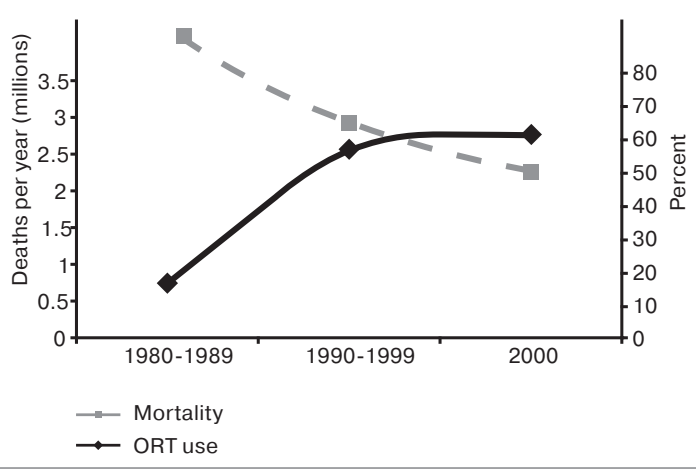

Pис. 1. Залежність між застосуванням ОРС та смертністю смертей, пов'язаних з діареєю. Згідно з оцінками експертів ВООЗ, їі використання при лікуванні інфекційних діарей дозволило знизити дитячу смертність з 4,6 млн в 1980 році до 1,5 млн випадків в 2000 році (рис. 1). 31990 року понад 150 країн взяли на себе зобов'язання по застосуванню оральної регідратації при лікуванні діарей.

Про ефективність застосування гіпоосмолярних розчинів для оральної регідратації при лікуванні гострої діареї було описано вище. Окрім зменшення осмолярності розчинів для оральної регідратації за рахунок зниження концентрації натрію та глюкози, пропонувались й інші шляхи підвищення їх ефективності. Одним 3 найбільш вдалих рішень була заміна глюкози на полімерні молекули. Полімери глюкози (амілопектини або мальтодекстрини) за рахунок поступового розщеплення дозволяють зменшити вихідну осмолярність розчину і в той же час забезпечити необхідну кількість молекул глюкози для потреб котранспорту натрію в тонкому кишечнику. Тобто полімери глюкози повільно розщеплюються в тонкій кишці та глюкоза, яка при цьому виділяється, підсилює реабсорбцію води й електролітів, які секретуються в просвіт кишечника під час діареї. Полімери також зменшують вплив зниженої толерантності до глюкози, яка може виникати під час гострих кишкових інфекцій, позитивно впливаючи на прояви діареї. Крім цього, мальтодекстрини виступають в якості пребіотиків - вони стимулюють ріст біфідобактерій в кишечнику людини.

Для отримання цих полімерів, як правило, використовується часткова гідролізація крох- 
малю рослинних продуктів, таких як рис, кукурудза, картопля, пшениця, сорго тощо. Раніше продукти, збагачені крохмалем, готувались безпосередньо перед вживанням і потім змішувались $з$ солями для регідратації. Останніми роками доступними стали розчини на основі полімерів глюкози у вигляді готового для розчинення порошку.

У великому огляді G.V. Gregorio et al. (2009) проаналізовані 34 дослідження, які охоплювали 4214 пацієнтів, присвячені вивченню ефективності розчинів для оральної регідратації на основі полімерів глюкози в порівнянні зі стандартними розчинами на основі глюкози. 27 з них стосувались педіатричної когорти. Ефективність оцінювалась по зниженню об'єму випорожнень протягом перших 24 годин, а також протягом всього періоду діареї. Додатковими критеріями були необхідність у проведенні позапланових внутрішньовенних інфузій та частота блювання. Результати свідчать про зменшення об'єму випорожнень протягом перших 24 годин у пацієнтів, які отримували розчин для оральної регідратації на основі полімеру глюкози. Порівняння проводили окремо $з$ гіперосмолярними $(\geq 310 \mathrm{mOcм} / л)$ та гіпоосмолярними $(\leq 270$ мОсм/л) розчинами на основі глюкози. Тривалість діареї у пацієнтів з полімерним ОРС становила 30-81 годину, а в групі з ОРС на основі глюкози - 34-91 годину. У дітей з холерою середня різниця в тривалості діареї становила 7,11 годин і була достовірною. При цьому частота побічних реакцій у вигляді гіпонатріємії, гіпокаліємії, персистенції діареї суттєво не відрізнялась між групами з різними типами ОРС [11].

В останньому метааналізі (2016) було встановлено, що при застосуванні гіперосмо лярних ОРС (27 досліджень, 3532 учасники) розчини на основі полімерів зменшували об'єм випорожнень на 65,47 мл/кг в перші 24 години та на 8,57 години скорочували тривалість діареї. При застосуванні ОРС $з$ осмолярністю $\leq 270$ (8 досліджень, 752 учасника) об'єм випорожнень в перші 24 години зменшувався на 24 мл/кг і на 8,24 годин скорочувалась тривалість діареї при вживанні розчинів на основі полімерів.

У рекомендаціях ВООЗ (2005) з лікування діарей відмічається краща ефективність полімерних розчинів для регідратації та рекомендується застосовувати їх, зокрема, при холері у дітей.

На ринку України сьогодні є гіпоосмолярний ОРС, що в своєму складі містить кукуруд- зяний мальтодекстрин та культуру Lactobacillus rhamnosus GG (LGG) - Регідрон Біо.

Результати багатьох досліджень свідчать про позитивний вплив пробіотичних препаратів на перебіг гострих та персистуючих діарей. В основному дослідники відмічають, що пробіотики скорочують тривалість діареї та зменшують тривалість стаціонарного лікування. За даними різних авторів, тривалість діареї скорочується, порівняно 3 терапією ОРС, на строк від 0,7 до 2,1 доби (у середньому 24 години) [7]. 3 усіх клінічних досліджень, присвячених ефективності пробіотиків при діареях у дітей, найбільш переконливі дані отримані при застосуванні штамів LGG та S. boulardii (високий рівень доказовості, сильна рекомендація, рівень I A).

Ефективність штамів LGG при діареї у дітей, у першу чергу, пов'язана з тим, що лактобацили $€$ одними 3 фізіологічно цінних компонентів біоценозу кишечника людини. Основними фізіологічними властивостями лактобацил є:

- пригнічення росту гнильних та гноєрідних бактерій;

- антибактеріальна активність, що зв'язана 3 продукцією ними в процесі бродіння вуглеводів, молочної кислоти, спирту, лізоциму, реутерину, плантарицину, лактоцидину та лактоліну; запобігають транслокації патогенних мікробів через слизову оболонку кишечника;

- підтримання колонізаційної резистентності організму за рахунок активної конкуренції з потенційними патогенами за лімітовані поживні субстрати та місця адгезіі на епітелії;

- стимулювання діяльності імунної системи хазяїна, індукція синтезу інтерферону та протизапальних інтерлейкінів, сприяння утворенню специфічних антитіл, вплив на специфічний та неспецифічний імунітет, стимуляція синтезу секреторного імуноглобуліну А, $\gamma$-інтерферону;

- участь у травній, біосинтетичній, детоксикуючій та інших функціях нормофлори кишечника людини;

- розщеплюють окремі токсини, канцерогени, алергени, запобігають абсорбції токсичних продуктів метаболізму, в першу чергу аміаку та окремих амінів;

- мають властивість вступати в антагонізм по відношенню до потенційних патогенів.

Також ефективність пробіотичних препаратів при лікуванні ГКІ пов'язана з їх позитивним 
впливом на муциновий шар та цитоскелет слизової оболонки шлунково-кишкового тракту. При ГКІ спостерігається зміна фізичних характеристик муцинового шару: зниження в'язкості за рахунок руйнування дисульфідних зв'язків між цистеїновими містками може призводити до транслокації мікроорганізмів 3 просвіту кишечника в тканини. Ці процеси розвиваються під дією патогенних мікроорганізмів, що мають певні фактори патогенності у вигляді ферментів, які здатні руйнувати слиз (нейрамінідаза, гіалуронідаза, муциназа). Тривала, у тому числі в постінфекційному періоді, зміна фізичних властивостей муцинового шару призводить до ризику розвитку запальних захворювань кишечника. Пробіотичні штами здатні збільшувати синтез муцину за рахунок активації гена MUC-3, підвищують синтез білків щільних з'єднань (окклудін, золудин, тощо), що змынює цитоскелет, утворюють масляну кислоту (необхідну для енергозабезпечення епітеліальних клітин), пригнічують апоптоз клітин слизової оболонки.

Найвища ефективність в скороченні тривалості гострої діареї показана при застосуванні LGG. Пробіотик зменшував тривалість гострої діареї на 1,1 дня. При чому, при ротавірусному гастроентериті цей показник був ще вищим і складав у середньому 2,1 дня.

У багатоцентровому клінічному дослідженні, що включало 287 дітей віком від 1 місяця до 3 років з гострими діареями різної етіології, було встановлено, що застосування LGG значно скорочує тривалість діареї порівняно з контрольною групою $(58,3 \pm 27,6$ та $71,9 \pm 35,8$ години, $\mathrm{p}=0,03)$, особливо при діареї яка спричине-

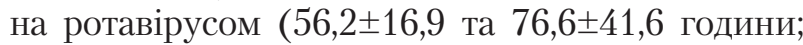
$\mathrm{p}<0,008)$. Ризик діареї, яка триває понад 7 днів, також був достовірно меншим у LGG групі (2,7\% та 10,7\%; p<0,01), як і тривалість перебування в стаціонарі.

В огляді S.J. Allen et al. (2010) проаналізовані результати 63 рандомізованих досліджень. Пробіотики в середньому скорочували тривалість діареї на 24,76 години та зменшували кількість випадків діареї, яка триває понад 4 дні. При цьому пробіотичні препарати показали високий профіль безпеки. В одному з останніх метааналізів, до якого включили дані 17 рандомізованих досліджень по вивченню ефективності пробіотиків для профілактики антибіотикоасоційованої діареї (ААД) у амбулаторних пацієнтів (n=3631), вставлено, що ризик розвитку ААД при вживанні проботиків знижувався з 17,7\% до 8,0\% [6]. У педіатричній популяції пробіотики також достовірно знижували ризик виникнення ААД (9\% порівняно з 18\% в контрольній групі). Вища ефективність відмічалась при застосуванні Lactobacillus rhamnosus GG та Saccharomyces boulardii. При цьому не було жодного повідомлення про побічну дію пробіотиків.

А в метааналізі 3 рандомізованих досліджень 3 вивчення ефективності пробіотиків для профілактики розвитку нозокоміальної діареї у дітей з'ясували, що саме LGG знижували частоту нозокоміальної діареї 3 13,9\% до 5,2\% (2 RCTs, n=1823; RR, 0.35; 95\% CI, 0.19 to 0.65).

Результати досліджень, проведених В.Ф. Учайкіним (2015), підтвердили високу ефективність Регідрону Біо при інфекційних діареях. За даним цього дослідження, використання Регідрону Біо у 30 дітей з ГКІ призвело до більш швидкого зникнення симптомів дегідратації, інтоксикації, абдомінальних болів, явищ метеоризму i нормалізації характеру випорожнень. Так, при застосуванні Регідрону Біо ознаки дегідратації у 72,2\% дітей зникали до кінця 1 доби і у 94,4\% хворих на 2 добу. У групі хворих, які приймали ОРС з осмолярністю 260 мОсм/л без пробіотичних штамів (група порівняння), прояви дегідратації в першу добу зникали у 26,3\%, на 2 добу у 68,4\%, а у 16\% хворих зберігались і на 3 день лікування. На 2 добу лікування при вживанні Регідрону Біо блювання зникало у всіх хворих і 95,6\% дітей не турбував біль у животі, в групі порівняння ці показники склали 81,8\% і 60,7\% відповідно. При вірусній етіології ГКІ тривалість діареї зменшувалась на 1 день $(\mathrm{p}<0,001)$. У групі порівняння на 4-5 добу лікування дисбіотичні зміни в кишечнику прогресували переважно за рахунок зниження вмісту біфідобактерій і зростання умовно-патогенної флори. При використанні Регідрону Біо достовірно зростала кількість лактобактерій і ентерококів, рівень біфідобактерій i кишкової палички не змінювався.

В роботі М.К. Бехтеревої (2016) використання Регідрону Біо у 40 дітей 3 вірусним гастроентеритом показало більш швидке зникнення діареї і високу прихильність дітей до терапії (гарні органолептичні властивості). 90\% пацієнтів, які отримували Регідрон Біо, випивали весь призначений на добу розчин. Серед пацієнтів (30 осіб), які отримували розчин з нормальною осмолярністю, тільки $40 \%$ могли випити весь розрахований об’єм ОРС за добу. 
У нашому дослідженні (2018) з вивчення ефективності Регідрону Біо у дітей з гострою респіраторною інфекцією (ГРІ), які отримували антибіотики, було виявлено, що додавання LGG попереджувало розвиток ААД у всіх пацієнтів.

Застосування ОРС у дітей з гострою респіраторною інфекцією

За даними літератури, частота симптомів порушення водно-електролітного балансу у хворих на ГРІ становить 25-50\%. Головними чинниками зневоднення при інфекційних захворюваннях, які не супроводжуються патологічними втратами рідини через блювання та пронос, вважають перспіраційні втрати та зменшення надходження рідини 3 питтям та їжею внаслідок зниження апетиту. Активація катаболічних процесів під час інфекційного захворювання супроводжується збільшенням вивільнення води і посиленням виведення її та розчинених у ній електролітів 3 сечею. Зростання теплопродукції призводить до збільшення втрат води 3 потом та через легені. За нормальних умов у дітей до 1 року життя рідина надходить з молоком (87\% води), в старшому віці близько 40\% води надходить з їжею і майже стільки ж - 3 питтям (45-48\%). Під час гострого періоду хвороби часто має місце недостатне надходження рідини за рахунок зниження апетиту та відмови дітей від пиття.

Обмеження у прийомі іжі, посилений енергетичний обмін може призводити до спустошення депо глюкози та глікогену і до переключення на обмін жирів, що проявляється зростанням рівня їх метаболітів, зокрема кетонових тіл. Ця тенденція частіше спостерігається у дитячому віці. Хоча кетонемія, яка не пов'язана з ендокринною патологією, зокрема з цукровим діабетом, вважається відносно доброякісною, у деяких дослідженнях підкреслюється прямий взаємозв'язок між кетонемією/кетонурією та такими клінічними критеріями, як важкість перебігу захворювання, лихоманкою, ризиком госпіталізації.

$\mathrm{У}$ нашій роботі (2016) ми виявили прямий зв'язок температурної реакції дітей з ГРІ з рівнем кетонових тіл в сечі. За нашими даними підвищення температури понад $39,5^{\circ} \mathrm{C}$ з $78 \%$ ймовірністю свідчить про наявність кетонурії.

У наших дослідженнях (2012) було встановлено, що 68,5\% дітей з респіраторними захворюваннями, які були госпіталізовані до інфекційного стаціонару, мали ознаки зневоднення. Серед симптомів зневоднення часті- ше виявлялась сухість слизових оболонок та спрага. В день госпіталізації сухість слизових оболонок спостерігалась у $45 \%$ хворих, спрага у 65\%. У 21,6\% пацієнтів відмічалось незначне зниження тургору тканин (вирівнювання шкірної складки $<1$ с.). Зменшення частоти сечовипускань було відмічено у 26,7\% дітей.

Як дегідратація, так і кетонемія/кетонурія, обтяжують перебіг гострих інфекцій дихальних шляхів і потребують швидкої корекції. Відновлення водно-електролітного балансу можливе за рахунок введення води та основних мінеральних речовин, а покращення енергетичного обміну потребує надходження продуктів, які містять вуглеводи.

Відповідно до існуючих рекомендацій лікарів при ГРІ одним з методів терапії є вживання великої кількості рідини. Як правило, це означає вживання напоїв у збільшеному об'ємі, ніж зазвичай. Проте існують повідомлення про небезпеку прийому великої кількості рідини. Так, при вживанні надмірної кількості води може розвинутись водяна інтоксикація. Цей стан пов'язаний з накопиченням води в судинному руслі, що може призводити до зниження концентрації натрію (гіпонатріємія) та переходу рідини за осмотичним градієнтом до внутрішньоклітинного простору та розвитку набряків. При зниженні концентрації натрію менше ніж 120 ммоль/л можуть 3'являтись симптоми набряку головного мозку у вигляді порушень свідомості, судом, а також периферичні набряки. 3 іншого боку, неадекватний прийом розчинів з високим вмістом натрію може викликати розвиток гіпернатріємії.

ОРС, завдяки збалансованому складу, дозволяє компенсувати втрати рідини, основних електролітів та енергії і має високий профіль безпеки при лікуванні зневоднення будьякої природи.

У нашому дослідженні, яке було проведене в клініці дитячих інфекцій НМУ імені О.О. Богомольця, для компенсації зневоднення у дітей з респіраторними захворюваннями застосовувався низькоосмолярний розчин для оральної регідратації. У результаті, вже 3 другого дня спостереження прояви дегідратації значно зменшились. Стан слизових оболонок та тургор шкіри у всіх пацієнтів нормалізувався. Лише у третини дітей залишалась спрага, а у 18,3\% зберігалось зменшення частоти сечопускань. На 3-й день спостереження у всіх пацієнтів симптоми зневоднення 
були відсутніми. При застосуванні ОРС зменшення кетонурії відбувалось швидше, ніж при прийомі звичайних видів пиття. Ймовірно, це пояснюється більш збалансованим складом та кращим засвоєнням глюкозо-електролітних розчинів.

За даними Ю.В. Марушко (2015), при застосуванні препарату Регідрон Оптім вже через 24 години вдається достовірно знизити частоту проявів неважкого ацетонемічного синдрому у дітей, а на 2-й день лікування досягти зникнення проявів інтоксикаційного синдрому, блювання, спастичного абдомінального болю, запаху ацетону у видихуваному повітрі, ознак зневоднення у всіх пацієнтів.
За даними С.С. Шостак (2017) включення в комплексні схеми терапії хворих на хронічний панкреатит в амбулаторних умовах препарату Регідрон Оптім дозволило швидко зменшити прояви інтоксикації, відновити втрачену працездатність, побороти втому, відновити сили та вже з перших діб суттєво покращити якість життя хворих.

Таким чином, застосування ОРС зі зниженою осмолярністю є виправданим засобом терапії гострої інфекційної патології у дітей та метаболічних порушень. При лікуванні гострих діарей та для профілактики розвитку ААД у дітей старше 3 років життя ефективним виявились гіпоосмолярні ОРС з додаванням штамів LGG.

\begin{tabular}{|c|c|c|}
\hline \multicolumn{3}{|c|}{ ПРЕПАРАТ } \\
\hline РЕГІДРОН & РЕГІДРОН ОПтім & РЕГІДРОН Біо \\
\hline \multicolumn{3}{|c|}{ Склад } \\
\hline $\begin{array}{l}1 \text { пакетик (18,9 г порошку) містить: } \\
\text { Натрію хлориду 3,5 г } \\
\text { Натрію цитрату 2,9 г } \\
\text { Калію хлориду 2,5 г } \\
\text { Глюкози } 10 \text { г }\end{array}$ & $\begin{array}{c}1 \text { пакетик (10,7 г порошку) містить: } \\
\text { Калію хлориду 0,75 г } \\
\text { Натрію хлориду } 1,3 \text { г } \\
\text { Натрію цитрату 1,45 г } \\
\text { Глюкози 6,75 г } \\
\text { допоміжні речовини: } \\
\text { калію ацесульфам, } \\
\text { ароматизатор лимонний }\end{array}$ & $\begin{array}{c}\text { 2-а пакетики містять: Глюкози 3,02 г } \\
\text { Натрію цитрату 0,58 г } \\
\text { Натрію хлориду 0,36 г } \\
\text { Калію хлориду 0,3 г Lactobacillus rhamnosus } \\
0,1 \text { г (1х109 KУO) } \\
\text { кукурудзяний мальтодекстрин 1,9 г }\end{array}$ \\
\hline пакетик розчиняється в 1,0 л води & пакетик розчиняється в 0,5 л води & два пакетики (А і Б) розчиняються в 0,2 л води \\
\hline \multicolumn{3}{|c|}{ Показання } \\
\hline $\begin{array}{l}\text { Відновлення водно-електролітної рів- } \\
\text { новаги } \\
\text { Додатково: } \\
\text { — холера; } \\
\text { - стани, при яких домінує блювота; } \\
\text { - ацетонемічнии синдром; } \\
\text { - теплові та фрізичні навантаження } \\
\text { у дорослих. } \\
\text { Профрілактика зневоднення при: } \\
\text { теплових та фрізичних навантажен- } \\
\text { нях, що призводять до інтенсивного } \\
\text { потовиділення у дорослих }\end{array}$ & $\begin{array}{c}\text { Відновлення водно-електролітної } \\
\text { рівноваги, корекція ацидозу при } \\
\text { гострій діареї, діареї з легким або } \\
\text { середнім ступенем дегідратації, } \\
\text { при теплових ураженнях, пов'яза- } \\
\text { них із порушеннями водно-елек- } \\
\text { тролітного обміну }\end{array}$ & $\begin{array}{c}\text { Відновлення водно-електролітної рівноваги, } \\
\text { корекція ацидозу при гострій діареї, діареї з } \\
\text { легким або середнім ступенем дегідратації, } \\
\text { при теплових ураженнях, пов'язаних із пору- } \\
\text { шеннями водно-електролітного обміну. } \\
\text { Додатково: } \\
\text { профрілактика та лікування зневоднення } \\
\text { і дисбіотичних порушень нормосрлори кишеч- } \\
\text { ника при: антибіотикоасоційованій діареї, } \\
\text { синдромі подразненого кишечника, } \\
\text { запорах, нерегулярному та неякісному } \\
\text { харчуванні тощо }\end{array}$ \\
\hline \multicolumn{3}{|c|}{ Протипоказання } \\
\hline $\begin{array}{l}\text { Гіперчутливість до активних речовин } \\
\text { або до будь-якого іншого компонента } \\
\text { препарату, тяжка дегідратація, втра- } \\
\text { та свідомості, гемодинамічний шок, } \\
\text { непрохідність кишечника, нестримне } \\
\text { блювання, ілеус. } \\
\text { Гіперкаліємія, ниркова недостатність, } \\
\text { цукровий діабет, артеріальна гіпер- } \\
\text { тензія ІІ-ІІІ ступеня }\end{array}$ & $\begin{array}{l}\text { Гіперчутливість до активних речо- } \\
\text { вин або до будь-якого іншого ком- } \\
\text { понента препарату, тяжка дегідра- } \\
\text { тація, втрата свідомості, гемодина- } \\
\text { мічний шок, непрохідність кишеч- } \\
\text { ника, нестримне блювання, ілеус }\end{array}$ & $\begin{array}{c}\text { Гіперчутливість до активних речовин або до } \\
\text { будь-якого іншого компонента препарату, } \\
\text { тяжка дегідратація, втрата свідомості, } \\
\text { гемодинамічний шок, непрохідність } \\
\text { кишечника, нестримне блювання, ілеус }\end{array}$ \\
\hline \multicolumn{3}{|c|}{ Застосування в період вагітність та грудного вигодовування } \\
\hline дозволений & дозволений & дозволений \\
\hline \multicolumn{3}{|c|}{ Умови зберігання } \\
\hline $\begin{array}{l}\text { Готовий розчин зберігати в } \\
\text { холодильнику } \\
\text { при температурі } 2-8^{\circ} \mathrm{C} \text { до } 24 \text { годин }\end{array}$ & $\begin{array}{c}\text { Готовий розчин зберігати в холо- } \\
\text { дильнику при температурі } 2-8^{\circ} \mathrm{C} \\
\text { протягом } 24 \text { годин }\end{array}$ & $\begin{array}{c}\text { Готовий розчин зберігати в холодильнику } \\
\text { при температурі 2-8 C } \\
\text { протягом } 24 \text { годин }\end{array}$ \\
\hline \multicolumn{3}{|c|}{ Примітки } \\
\hline $\begin{array}{l}\text { Перевага у застосуванні } \\
\text { при інтенсивних втратах електролітів }\end{array}$ & $\begin{array}{c}\text { Приємний смак, адаптований до } \\
\text { застосування у дітей }\end{array}$ & $\begin{array}{l}\text { Сприяє захисту та відновленню } \\
\text { мікрофрлори кишечника }\end{array}$ \\
\hline
\end{tabular}




\section{ЛITЕРАТУРА}

1. Крамарьов С.О., Євтушенко В.В, Дорошенко В.О. Регідратаційна терапія при гострих респіраторних інфекціях у дітей // Сучасна педіатрія. - 2012. - №1. - С. 61-64.

2. Крамарьов С.О., Закордонець Л.В., Євтушенко В.В. Використання розчину для оральної регідратації (оральної регідратаційної солі) з додаванням пробіотичного штаму для лікування дітей із гострою інфекційною патологією // Актуальная инфектология. - 2018. - Том 6, №1. - С. 18-23.

3. Учайкин В.Ф., Новокшонов А.А. Клиническая эффективность применения гипоосмолярного перорального раствора с Lactobacillus GG для регидратации при кишечных инфекциях у детей // Детские инфекции. - 2015. - Т. 14, №1. - С. 20-26.

4. Acute diarrhea in adults and children: a global perspective. World Gastroenterology Organisation Global Guidelines, 2012.

5. Adam C. Levine at al. Prediction of Severe Disease in Children with Diarrhea in a Resource-Limited Setting // PLoS One. - 2013. Vol. 8(12). - P. e82386.

6. Anigilaje E.A. Management of Diarrhoeal Dehydration in Childhood: A Review for Clinicians in Developing Countries // Front Pediatr. 2018. - Vol. 6.- P. 28. Epub 2018 Feb 23.

7. Bhattacharya S.K. History of development of oral rehydration therapy // Indian J Public Health. - 1994. - V.38(2). - P.39-43.

8. Gregorio G.V., Gonzales M.L., Dans L.F., Martinez E.G. Polymer-based oral rehydration solution for treating acute watery diarrhoea. Cochrane database Syst Rev. - 2016. - Vol. 12.-CD006519.
9. Guarino A., Ashkenazi Sh., Gendrel D. et al. Evidence-based Guidelines for the Management of Acute ESPGHAN/ESPID Evidence-based Guidelines for the Management of Acute Gastroenteritis in Children in Europe. Update 2014.

10. Hojsak I. Prebiotics Probiotics for the Prevention of Nosocomial Diarrhea in Children / I. Hojsak, H. Szajewska, R.B. Canani, A. Guarino, F. Indrio, S. Kolacek, R. Orel, R. Shamir, Y. Vandenplas, J.B. van Goudoever, Z. Weizman, ESPGHAN Working Group for Probiotics // J. Pediatr. Gastroenterol. Nutr. - 2018. - Vol. 66(1). - P. 3-9.

11. Kimberly Pringle at al. Comparing the accuracy of the three popular clinical dehydration scales in children with diarrhea // Int. J. Emerg. Med. 2011.-Vol. 4. - P. 58.

12. Plaza-Diaz J. Immune-Mediated Mechanisms of Action of Probiotics and Synbiotics in Treating Pediatric Intestinal Diseases / J. Plaza-Diaz, F.J. Ruiz-Ojeda, M. Gil-Campos, A. Gil // Nutrients. - 2018. — Vol. 5; 10(1).

13. Pomorska D. Comparison of three dehydration scales showed that they were of limited or no value for assessing small children with acute diarrhoea / D. Pomorska, P. Dziechciarz, E. Mduma, J. Gidion, A. Falszewska, H. Szajewska // Acta Paediatr.-2018, Feb 20.

14. Szajewska H. Probiotics for the Prevention of Antibiotic-Associated Diarrhea in Children / H. Szajewska, R.B. Canani, A. Guarino, I. Hojsak, F. Indrio, S. Kolacek, R. Orel, R. Shamir, Y. Vandenplas, J.B.van Goudoever, Z. Weizman, ESPGHAN Working Group for ProbioticsPrebiotics // J. Pediatr. Gastroenterol. Nutr. - 2016. - Vol. 62(3). - P. 495-506.

\section{Сведения об авторах:}

Крамарев Сергей Александрович - д.мед.н., проф., зав. каф. детских инфекционных болезней нму имени А.А. Богомольца. Адрес: г. Киев, ул. Дегтяревская, 23: тел : (044) 483-74-62. Закордонец Людмила Владиславовна - к.мед.н, ассистент каф. детских инфекционных болезней НМУ имени А.А. Богомольца. Адрес: г. Киев, ул. Дегтяревская, 23; тел.: (044) 483-74-62. Статья поступила в редакцию 17.11.2018 г.; принята в печать 04.03.2019 г.

\footnotetext{
(1)

PuAvinas GRe

\section{Dear Colleagues}

It is a great pleasure and an honor to extend to you a warm invitation to attend the $4^{\text {th }}$ Baltic Paediatric Congress, to be held May 16-18 in Vilnius, Lithuania.

This biannual Congress is organized by Lithuanian Paediatric Society, Latvian Paediatric Association, Estonian Paediatric Association with official participation of Polish Paediatric Society and Ukrainian Academy of Paediatrics. The Congress is organized under the auspices of European Academy of Paediatrics (EAP/UEMS-SP).
}

\section{CONTACTS}

Permanent Secretariat

- Phone +370 69985185

- arunas.valiulis@mf.vu.lt

\section{Conference PCO Kongreslita}

- Phone +370 68734393

- info@bpc2019.eu

\footnotetext{
More information: http://bpc2019.eu
} 


\title{
В.В. Бережний, Ю.І. Бондарець
}

\section{Порушення мікробіому товстого кишечника та його корекція у хворих на ювенільний ревматоїдний артрит}

\author{
Національна медична академія післядипломної освіти імені П.Л. Шупика, м. Київ, Україна
}

\author{
SOVREMENNAYA PEDIATRIYA.2019.2(98):76-84; doi 10.15574/SP.2019.98.76
}

\begin{abstract}
Мета: дослідити стан мікробіоти товстого кишечника у хворих з ювенільним ревматоїдним артритом (ЮРА) на тлі лікування базисними, біологічними та хворобо-модифрікуючими препаратами та оцінити ефективність комбінованого синбіотичного препарату (Ротабіотик) при виявлених порушеннях. Матеріали і методи. Обстежено 29 дітей віком від 1,5 до 16 років з ЮРА. Проведено загальноклінічне, інструментальне обстеження згідно з Уніфікованим клінічним протоколом медичної допомоги дітям, хворим на ювенільний артрит (наказ МО3 України №832 від 22.10.2012 р.). Додатково усім дітям проведено бактеріологічне дослідження фекалій до та після виявлених порушень мікробіоти кишечника.

Результати. При обстеженні шлунково-кишкового тракту у хворих з ревматоїдним артритом мали місце скарги: періодичний біль у животі у $23(79,31 \%)$, зниження апетиту - у 20 (68,97\%), метеоризм - у 12 (41,38\%), схильність до запорів - у $10(34,48 \%)$ дітей. Встановлено порушення мікробіоценозу у 23 пацієнтів за рахунок зменшення кількості лакто- та біфідобактерій < $10^{6} \mathrm{KVO}$, а також збільшення кількості умовно-патогенних та патогенних мікроорганізмів: гриби роду Candida - у 5 (21,74\%), стафілококи (гемолітичні, плазмокоагулюючі) - у 5 (21,74\%), Klebsiella pneumoniie - у $3(14,04 \%)$, Enterococcus faecium - у 2 (8,70\%), E. coli зі зміненими ферментативними властивостями - у $2(8,70 \%)$, Proteus mirabilis у 1 (4,35\%) хворого. Дисбіоз І ст. діагностовано у 8 (34,78\%), II ст. — у 9 (39,13\%), III ст. — у 6 (26,09\%) пацієнтів. Після корекції мультикомпонентним синбіотичним комплексом (Ротабіотик) спостерігалась нормалізація мікрофрлори товстого кишечника у 16 дітей $(69,57 \%)($ (р<0,001). Дисбіотичні зміни I ст. зберігались у 7 (30,43\%) дітей, у яких на початку дослідження діагностовано дисбіоз ІІ-ІІІ ст.

Висновки. У хворих на ЮРА на тлі лікування базисними протиревматичними, нестероїдними протизапальними та біологічними препаратами встановлено порушення мікробіоти товстого кишечника з розвитком дисбіозу різного ступеня, що ускладнює перебіг основного захворювання і погіршує якість життя. Використання мультикомпонентного синбіотичного препарату (Ротабіотик) у комплексному лікуванні хворих на ЮРА $€$ есрективним засобом корекції порушень мікробіоценозу товстого кишечника.
\end{abstract}

Ключові слова: діти, ювенільний ревматоїдний артрит, мікробіоценоз товстого кишечника, дисбіоз, синбіотичний препарат.

\section{Impaired colon microbiome and its correction in patients with juvenile rheumatoid arthritis V.V. Berezhniy, Yu.I. Bondarets \\ Shupyk National Medical Academy of Postgraduate Education, Kyiv, Ukraine}

Objective: to investigate the state of the colon microbiota in patients with juvenile rheumatoid arthritis (JRA) against the background of treatment with basic, biological disease-modifying drugs and to evaluate the effectiveness of the combined synbiotic preparation (Rotabiotic) with the revealed violations. Materials and methods. In total of 29 children aged 1.5 to 16 years old were diagnosed with juvenile rheumatoid arthritis. A general clinical, instrumental examination was performed in accordance with a unified clinical protocol of medical care for children suffering from juvenile rheumatoid arthritis (Ministry of Health Order № 832 of October 22, 2012). In addition, all children underwent bacteriological examination of feces before and after the identified violations of the intestinal microbiota.

Results. When examining the gastrointestinal tract in patients with rheumatoid arthritis, there were complaints: intermittent abdominal pain in $23(79.31 \%)$, loss of appetite - in $20(68.97 \%)$, flatulence - in $12(41.38 \%)$, tendency to constipation - in $10(34.48 \%)$ children. A violation of the microbiocenosis was found in 23 patients by reducing lactic and bifidobacteria of $<10^{6} \mathrm{CFU}$, as well as increasing the number of conditionally pathogenic and pathogenic microorganisms: Candida fungi in $5(21.74 \%)$, staphylococci (hemolytic, plasma-coagulating) in $5(21.74 \%)$, Klebsiella pneumoniae in $3(14.04 \%)$, Enterococcus faecium in $2(8.70 \%)$, E. coli with altered enzymatic properties in $2(8.70 \%)$ and Proteus mirabilis in $1(4.35 \%)$ of the patient. I degree dysbiosis was diagnosed in $8(34.78 \%)$, stage II - in $9(39.13 \%)$, stage III - in $6(26.09 \%)$ patients. After correction with a multicomponent synbiotic complex (rotabiotic), colon microflora normalization was observed in $16(69.57 \%)$ children $(\mathrm{p}<0.001)$. Dysbiotic changes in I st were preserved in 7 children $(30.43 \%)$, who were diagnosed with dysbiosis II-III at the beginning of the study.

Conclusions. In patients with juvenile rheumatoid arthritis, on the background of treatment with basic antirheumatic drugs, non-steroidal anti-inflammatory drugs and biological antirheumatic drugs, a violation of the microbiota of the large intestine with the development of dysbiosis of various degrees has been established, which complicates the course of the underlying disease and worsens the quality of life. The use of a multicomponent synbiotic drug (rotabiotics) in the complex treatment of patients with JRA is an effective means of correcting disorders of the colon microbiocenosis. Key words: children, juvenile rheumatoid arthritis, colon microbiocenosis, dysbiosis, synbiotic drug.

\section{Нарушение микробиома толстого кишечника и его коррекция у больных ювенильным ревматоидным артритом В.В. Бережной, Ю.И. Бондарец \\ Национальная медицинская академия последипломного образования имени П.Л. Шупика, г. Киев, Украина}

Цель: исследовать состояние микробиоты толстого кишечника у больных ювенильным ревматоидным артритом (ЮРА) на фоне лечения базисными, биологическими болезньмодифицирующими препаратами и оценить эфффективность комбинированного синбиотического препарата (Ротабиотик) при выявленных нарушениях.

Материалы и методы. Обследовано 29 детей в возрасте от 1,5 до 16 лет с ЮРА. Проведено общеклиническое, инструментальное обследование согласно Унисрицированному клиническому протоколу медицинской помощи детям, больным ювенильным артритом (приказ М3 Украины №832 от 22.10.2012 г.). Дополнительно всем детям проведено бактериологическое исследование фекалий до и после выявленных нарушений микробиоты кишечника.

Результаты. При обследовании желудочно-кишечного тракта у больных ревматоидным артритом имели место жалобы: периодическая боль в животе у $23(79,31 \%)$, снижение аппетита - у $20(68,97 \%)$, метеоризм - у $12(41,38 \%)$, склонность к запорам - у $10(34,48 \%)$ детей. Установлено нарушение микробиоценоза у 23 пациентов за счет уменьшения лакто- и бифидобактерий $<10^{6} \mathrm{KOE}$, а также увеличения количества условнопатогенных и патогенных микроорганизмов: грибы рода Candida - у 5 (21,74\%), стасрилококки (гемолитические, плазмокоагулирующие) у $5(21,74 \%)$, Klebsiella pneumoniae - у $3(14,04 \%)$, Enterococcus faecium - у $2(8,70 \%)$, E. coli с измененными фрерментативными свойствами у $2(8,70 \%)$ и Proteus mirabilis - у $1(4,35 \%)$ больного. Дисбиоз I ст. диагностирован у 8 (34,78\%), II ст. - у $9(39,13 \%)$, III ст. - у $6(26,09 \%)$ пациентов. После коррекции мультикомпонентным синбиотическим комплексом (Ротабиотик) наблюдалась нормализация микросрлоры толстого 
кишечника у 16 (69,57\%) детей (р<0,001). Дисбиотические изменения I ст. сохранялись у 7 (30,43\%) детей, у которых в начале исследования диагностирован дисбиоз II-III ст.

Выводы. У больных ЮРА на фоне лечения базисными противоревматическими, нестероидными противовоспалительными и биологическими противоревматическими препаратами установлено нарушение микробиоты толстого кишечника с развитием дисбиоза различной степени, что осложняет течение основного заболевания и ухудшает качество жизни. Использование мультикомпонентного синбиотического препарата (Ротабиотик) в комплексном лечении больных ЮРА является эффективным средством коррекции нарушений микробиоценоза толстого кишечника. Ключевые слова: дети, ювенильный ревматоидный артрит, микробиоценоз толстого кишечника, дисбиоз, синбиотический препарат.

\section{Вступ}

$\mathrm{K}^{\mathrm{n}}$ ишковий гомеостаз визначається станом нормальної мікробіоти слизової оболонки, колонізаційною резистентністю, мукозальним імунітетом. Кількісний та якісний склад мікрофлори дитини служить чутливим індикатором здоров'я і є клінічним маркером порушення гомеостазу. Важлива роль при цьому належить мікробіому товстого кишечника як одному з найбільших біотопів, що містять нормальну мікрофлору людини. Кожна людина має унікальну, тільки ій притаманну, мікрофлору, яка залежить від особливостей режиму харчування, складу сім'ї, захворювань і їх лікування, регіональних відмінностей тощо.

Мікробіом розглядається як додатковий орган людини з впливом на всі функції організму. Його маса в товстому кишечнику становить від 1,2 до 2 кг.

Останніми роками сформувалося поняття типів кишкових мікробних співтовариств (ентеротипів або кластерів). Виділяють три ентеротипи: перший ентеротип включає роди Bacteroides i Parabacteroides, у тому числі лакто- та біфідобактерії, які володіють високою активністю щодо ферментації вуглеводів, білків та гліколізу. До другого типу відносять рід Prevotella. Третій ентеротип складається з родів Ruminococcus, Cloctridiales (тип Firmicutes), які спричиняють деструкцію муцину, підвищуючи проходження вуглеводів через слизову оболонку кишечника. Формування ентеротипів багато в чому залежить від харчування.

Основний резервуар мікробіоти людини знаходиться у товстому кишечнику і представлений облігатною (головною) мікрофлорою анаеробними сахаролітичними бактеріями (Bifidobacterium, Lactobacillus, Propionibacterium, Bacteroides). Перші три роди бактерій, які належать до першого ентеротипу, відіграють головну роль у підтриманні фізіологічного стану кишкового біоценозу [16]. Друга група мікробіоценозу (другий ентеротип) - це факультативна (супутня) мікрофлора (Escherichia coli, Enterococcus, Fusobacterium, Clostridium та ін.), яка представлена умовно-патогенними видами, що виконують певні фізіологічні функції (синтез біологічно активних речовин, активація імунної системи, метаболізм речовин тощо). Проте при перевищенні їх популяцій у людини можуть виникати захворювання кишкового тракту. До третьої групи біоценозу належить транзиторна (алохтонна) мікрофлора (Staphylococcus aureus, Klebsiella, Proteus, Enterobacter, Bacillus та ін.), яка знаходиться у нормі в товстому кишечнику в незначній кількості.

До складу мікробіому входять бактеріальний (бактеріом), вірусний (віром), фаги бактерій та архей (фагобіом), група вірусів, які вибірково вражають бактеріальні клітини (бактеріофаги), грибковий (міком), протозойний (найпростіші).

Основними функціями мікробіоти є: метаболічна, захисна, імуногенна, генетична, детоксикаційна, синтетична (синтез нутрієнтів, вітамінів групи В, К, С, фолієвої та нікотинової кислот). При цьому головну роль виконують біфідо- та лактобактерії.

\section{Роль біфідобактерій у мікробіомі людини}

Згідно з класифікацією, рід Bifidobacterium складається з 32 видів, з яких найчастіше в кишечнику дітей знаходять $B$. bifidum, B. longum, B. breve, B. infantis та B. adolescentes.

Формування мікробної екологічної системи дитини починається з періоду новонародженості при проходженні через пологові шляхи матеpi та при грудному вигодовуванні. У дітей на грудному вигодовуванні домінує спектр біфідобактерій, представлений вищезазначеними видами. Стимуляцію росту нормальної мікрофлори в грудному періоді дитини здійснюють біфідогенні фактори грудного молока - олігосахариди. Найбільш значущими фізіологічними функціями біфідофлори у людей $є$ участь у метаболічних процесах - ферментації вуглеводів з утворенням коротколанцюгових жирних кислот (оцтової, молочної, мурашиної та бурштинової), що є трофічним субстратом для колоноцитів [18]. Біфідобактерії беруть участь у метаболізмі жовчних кислот, холестерину, гормонів, ксенобіотиків; синтезують бактеріоцини, антибіотики, лізоцим, пероксид водню; володіють високою імуностимулюючою активністю; 
покращують процеси гідролізу та абсорбцію ліпідів, протеїнів, вуглеводів; беруть участь у мінеральному обміні (заліза, кальцію, магнію).

Однією з важливих функцій біфідобактерій є перешкоджання адгезії і колонізації кишечника умовно-патогенною мікрофлорою (УПМ). Факторами прикріплення бактерій до епітеліальних клітин або субстрату (адгезії) є ворсинкоподібні структури - вирости, які виявлені у B. bifidum, B. longum subsp longum, B. breve, B. dentium, B. adolescentes та B. animalis subsp. lactis. Розміри ворсинкоподібних структур (ниток) різні i відрізняються довжиною, висотою та шириною ворсинок [23]. У якості адгезинів важливу роль відіграють поверхнево-активні білки з ферментативною активністю. У B. bifidum адгезином до муцину служить фермент трансальдолаза [24]. Ще одним фактором адгезії біфідобактерій до епітеліальних клітин є цукролітичний фермент енолаза, а також полімер ліпотейхоєва кислота [20,21,30]. Завдяки наявності кількох факторів адгезії біфідобактерії успішно конкурують у боротьбі за сайти зв'язування на слизовій 3 патогенними та умовно-патогенними мікроорганізмами та при різноманітних патологічних станах дозволяють розкрити патогенетичну сутність мікроекологічних порушень кишечника [6].

\section{Роль лактобактерій у мікробіомі людини}

Широким спектром фізіологічних функцій у біоценозі товстого кишечника володіють лактобацили, які також розповсюджені в інших екосистемах: вагінальний біотоп, порожнина рота. Колонізація лактобацилами новонародженої дитини розпочинається при проходженні пологових шляхів матері, а також мікробним складом грудного молока. Грудне молоко крім біфідобактерій містить також лактобацили, клостридії, стрептококи, стафілококи і бактероїди. Одними з перших у грудному молоці були виділені Lactobacillus gasseri, fermentum, rhamnosus, lactis, salivarius, reuteri. Надалі відбувається зміна якісного складу мікробіоти дитини при введенні прикорму та харчуванні різними продуктами. Інший склад мікробіому дитини при штучному вигодовуванні та при частих використаннях антибактеріальних препаратів.

Рід Lactobacillus включає близько 60 видів, типовим представником цього виду є Lactobacillus delbrueckii ssp Bulgaricus. Одним 3 перших визначив роль молочнокислих бактерій (МКБ), переважно болгарської палички, у покращенні фізичного та психічного здоров'я людей I.I. Мечников, який розробив та використовував чисті культури МКБ («Лактобацимен»). На сьо- годні Lactobacillus bulgaricus використовується при створенні багатьох пробіотиків, кисломолочних продуктів (йогуртів, заквасок). Lactobacillus bulgaricus є транзиторним мікроорганізмом. Незважаючи на те, що вона не володіє адгезивними властивостями, має важливе значення для становлення нормального мікробіоценозу кишечника, володіє пригнічуючою властивістю по відношенню до E.coli, сальмонел, стрептококів шляхом продукції антибактеріальних речовин - перекису водню, молочної кислоти, термолабільної бактеріоциноподібної субстанції, чутливої до дії протеаз, та термостабільної речовини $[2,19,27]$. Вона здатна розщеплювати лактозу у дітей при іï непереносимості. Деякі штами Lactobacillus bulgaricus стимулюють вироблення інтерферону, що свідчить про їх важливу захисну роль в імунній системі.

Лактобацили характеризуються високим рівнем синтезу молочної кислоти, адгезією до епітелію, імуномоделюючою активністю, широким спектром синтезу бактеріоцинів (перекис водню, лактоцин, плантацин, ацидоцин, баварицин тощо). Беруть активну участь у метаболізмі білків, жирів, вуглеводів, жовчних кислот, холестерину, оксалатів, сприяють елімінації з кишечника Helicobacter pylori.

Слід зазначити, що існує штамоспецифічність індигенної мікрофлори по відношенню до метаболічної, бар'єрної, захисної, імунної та інших функцій. Однією 3 найважливіших функцій нормальної мікрофлори людини є стимуляція вродженого імунітету, формування імуногенної толерантності з переважанням Th-1 відповіді, модуляція продукції цитокінів - фактору некрозу пухлини $\alpha$ (ФНО- $\alpha$ ), інтерферону $\gamma$ (IHФ- $\gamma$ ), інтерлейкіну 12 (IL12) та протизапальних - IL4, IL10, модуляція дендритних клітин, секреція sIgA [6].

Найчастіше $з$ біотопів людини виділяють Lactobacillus acidophilus, casei, plantarum, fermentum, brevis, salivarius, gasseri, helveticus, rhamnosus, reuteri [17].

Одним 3 найбільш досліджених мікроорганізмів кишечника дітей є Lactobacillus acidophilus, яка стійка до шлункового соку та має високу адгезивну здатність до слизової оболонки кишечника, підсилюючи, таким чином, ii бар'єрну функцію. Доведено, що L. acidophilus продукує природний антибіотичний фактор - ацидоцин, який володіє бактерицидною дією по відношенню до метицилінрезистентного золотистого стафілокока та Clostridium difficile [2,26]. Має високий антимікробний ефект проти 
E. coli, Salmonella, Candida albicans, тому широко призначається пацієнтам, які страждають на кишкові розлади (діарея, синдром подразненого кишечника). Завдяки високій адгезивній активності до слизової оболонки піхви, шийки матки та уретри вона використовується для лікування та профілактики інфекцій сечовивідної системи, бактеріального вагінозу. Відновленню нормофлори сечовивідних шляхів i піхви сприяє вироблення перекису водню i зниження pH. Використання L. acidophilus у комплексному лікуванні Helicobacter pylori підвищує ефективність терапії [1].

Під впливом різних екзо- та ендогенних факторів (антибактеріальна терапія, порушення харчування дітей, використання консервантів та різних лікувальних засобів, вплив алкогольних продуктів, стрес) виникають зміни кількісного та якісного складу мікрофлори, тобто розвиток дисбіозу. Зміна складу кишкової мікрофлори може сприяти пошкодженню ентероцитів, зниженню активності системи локального імунного захисту та порушенню фізіологічних процесів у кишечнику, що призводить до підвищеної проникності для макромолекул та компонентів коменсальної мікрофлори, порушення моторики, зниження захисних властивостей приепітеліального слизового бар'єру та створення умов для патогенних мікроорганізмів 3 розвитком позакишкових захворювань [22,11,14]. У літературі зустрічаються такі назви синдрому підвищеної проникності: синдром «дірявого» кишечника або «протікання».

Порушення ентеротипу кишкового мікробіому відображається на стані макроорганізму і може призвести до розвитку таких захворювань, як ожиріння, цукровий діабет, ревматоїдний артрит, функціональні і запальні зміни кишечника.

При дисбіозі кишечника можливий розвиток захворювання шлунково-кишкового тракту (функціональна диспепсія, хронічний гастродуоденіт, виразкова хвороба та ін.), обумовленого Helicobacter pylori, що сприяє високій частоті розвитку ерозивно-виразкових пошкоджень слизової оболонки гастродуоденальної зони, високій проникності слизової оболонки для антигенів та патогенних мікроорганізмів (Ureaplasma urealyticum, Clostridium difficile, клебсієла, кишкова паличка, стафілококи).

На сьогодні встановлена роль кишкової бактеріальної інфекції як пускового (тригерного) фактору розвитку реактивних артритів (PA).
Це стосується таких збудників, як Yersinia, Salmonella, Shigella, Campylobacter, Chlamydia, що через пошкоджений бар'єр кишечника потрапляють у кров'яне русло та синовіальні клітини суглобів, викликаючи розвиток аутоімунного запалення [25].

$\mathrm{Y}$ розвитку PA у дітей велике значення мають спадкові та середовищні фактори, серед яких найбільшу роль грає вірусна або віруснобактеріальна інфекція. За даними деяких авторів, питома вага гострих респіраторних вірусних інфекцій, які спровокували розвиток ювенільного РА (ЮРА), становила 42\% випадків [3].

Інфекційна теорія розвитку РА підтверджена результатами дослідження, проведеними в ревматологічному відділенні наукового центру здоров'я дітей РАМН. Так, у 70\% хворих на ЮРА виділені маркери різноманітних бактеріальних інфекцій у біологічних рідинах, при цьому у 50\% пацієнтів частіше зустрічались збудники хламідійної, мікоплазменої, стрептококової, стафілококової інфекції [15].

Артритогенною активністю володіють також віруси (парвовірус В19, віруси ЕСНО, Коксакі, Епштейн-Барр). За даними деяких досліджень, вірус Епштейн-Барр виявлений у синовіальній оболонці та рідині [28]. Також у пацієнтів з РА у синовіальній рідині виявлялися антитіла до цитомегаловірусу, вірусу краснухи, кору, герпесвірусів у поєднанні 3 мікоплазмою та хламідіями [12].

Таким чином, сформувалась концепція одного з ланцюгів патогенезу РА - ролі патогенної мікрофлори та вірусної інфекції як тригерного фактору в механізмі розвитку аутоімунного захворювання.

При РА окрім ураження суглобів спостерігаються зміни в інших органах і системах. Серед позасуглобових системних проявів РА виявляється патологія товстого кишечника з диспептичними проявами (абдомінальний біль, діарея, запор, метеоризм) та наявністю кишкового дисбіозу різного ступеня зі зменшенням кількості лакто- та біфідобактерій, формуванням вірусно-бактеріально-грибкових асоціацій [4]. При тривалості захворювання п'ять і більше років, за даним авторів, у 27\% пацієнтів з РА за результатами ендоскопії і морфологічного дослідження виявлений синдром подразненого кишечника, а у більшості хворих (72,9\%) діагностований хронічний невиразковий коліт i/або виразковий проктосигмоїдит.

За результатам дослідження інших авторів, у хворих на РА при проведенні морфологічного 
дослідження біоптату слизової товстого кишечника виявлені зміни у власній пластинці (lamina propria) з інфільтрацією лімфоцитами, плазмоцидами, мікроерозіями [10].

Морфологічні зміни товстого кишечника при РА підтверджені також результатами ще одного дослідження. Так, при моделюванні ЮРА у експериментальних тварин виявлені ультраструктурні ознаки дистрофії ендотеліоцитів слизової оболонки товстої кишки, наявність запальних інфільтратів з лімфоцитів, опасистих клітин і макрофагів навколо судин у власній пластині слизової оболонки, що свідчить про розвиток аутоімунного васкуліту та коліту [7].

Серед причин, які призводять до порушення нормального мікробіоценозу товстого кишечника, важливе місце займає вплив фармакологічних препаратів. Рядом досліджень встановлений негативний вплив антибіотикотерапії на стан мікробіому кишечника, що корелює з ризиком розвитку ЮРА. При повторних курcax антибіотикотерапії, особливо у дітей раннього віку, виникають великі труднощі у відновленні кількісного та якісного складу мікрофлори кишечника, що спричиняє функціональні та метаболічні порушення у його роботі з високою вірогідністю розвитку аутоімунних захворювань [9].

Крім антибіотиків на стан мікробіому кишечника впливають протиревматичні засоби, імунобіологічна терапія. За даними деяких авторів, у 76\% хворих на РА, які лікувались нестероїдними протизапальними препаратами (НПЗП) та метотрексатом, виявлявся дисбіоз кишечника, переважно III-IV ст. Розвиток дисбіозу також мав місце у пацієнтів, які приймали НПЗП разом з глюкокортикостероїдами (ГКС), - 42,2\% обстежених. У всіх обстежених встановлені якісні та кількісні зміни мікрофлори кишечника за рахунок зниження лактоi біфідобактерій. У пацієнтів, які приймали НПЗП і метотрексат, виділялись також УПМ (Enterobacter spp, Clostridia spp) і мікробні асоціації УПМ з Candida spp. У хворих, що отримували системні ГКС, переважав кандидозний дисбіоз (42,8\% випадків), у той час як при лікуванні лише НПЗП у фекаліях виявлялися гемолізуюча паличка та золотистий стафілокок - 17,6\% обстежених [8].

Результатами іншого дослідження було встановлено, що при лікуванні РА тільки НПЗП порушення мікробіоценозу відмічалось у 75\% хворих, з них у 35\% випадків мав місце дисбіоз кишечника III-IV ст. і при цьому у 12\% пацієнтів виявлялася тільки Clostridium perfringens [13].

За даними закордонних авторів, на ранніх стадіях РА (тривалість хвороби $\leq 6$ міс.) за допомогою проточної цитометрії РНК-гібридизації і ДНК-фарбування у фекальному мікробіомі хворих, які приймали хворобо-модифікуючі препарати та ГКС, виявлено зменшення кількості біфідобактерій та бактерій групи Васteroides - Porphyromonas - Prevotella, Bacteroides fragilis та підгрупи Eubacterium rectale - Clostridium coccoides [29].

Важливі результати щодо негативного впливу хворобо-модифікуючих препаратів на мікробіоценоз товстого кишечника у хворих на ЮРА отримані при дослідженні пацієнтів у відділенні хвороб сполучної тканини ДУ «Інститут ПАГ НАМН України». У переважної більшості пацієнтів $(89,1 \%)$ були виявлені клінічні та бактеріологічні ознаки дисбіозу II-III ст.: помірно виражений абдомінальний біль і диспептичний синдром, зниження вмісту біфідоі лактофлори та збільшення патогенних мікроорганізмів - золотистого стафілокока, грибів роду Candida, ентеробактерій, кишкової палички зі слабкими ферментативними властивостями [12]. Дослідники вважають, що пригнічення росту пробіотичної мікрофлори пов'язано з лікуванням РА метотрексатом, диклофенаком, метилпреднізолоном. Підтвердженням даного положення є результати дослідження in vitro щодо негативного впливу базисних протиревматичних препаратів на проліферативну активність музейного штаму L. acidophilus ВКПМВ-2707. Для корекції вищевказаних змін мікробіоценозу автори використовували мультикомпонентний пробіотик (біфідобактерії, лактобацили, пропіоновокислі бактерії, лактококи, стрептококи, оцтовокислі бактерії, екстракт прополісу) 20-денним курсом кожні 2 місяці протягом 6 місяців. Встановлені позитивні зміни результатів бактеріологічного дослідження фекалій: підвищення вмісту біфідо-, лактофлори та зменшення кількості дітей з наявністю у фекаліях УПМ. Однак помітної позитивної динаміки гістологічної картини слизової товстого кишечника при застосуванні базисної та протизапальної терапії не виявлено.

Таким чином, наведені дані свідчать про важливу роль патогенної мікрофлори і вірусної інфекції як одного з важливих факторів у механізмі розвитку аутоімунного захворювання, що 
виникає внаслідок порушення мікробіому та епітеліального бар'єру кишечника. Тому якісні і кількісні зміни мікробіому кишечника у хворих на ЮРА потребують використання засобів, які призводять до нормалізації мікробіоценозу.

У доступній літературі опубліковані дані лише поодиноких досліджень щодо використання пробіотиків у комплексному лікуванні хворих на ЮРА. Але вони не дають чітких уявлень про вплив окремих препаратів (НПЗП), базисної та імунобіологічної терапії на стан мікробіоти у дітей з РА, особливо в ранньому періоді захворювання, з урахуванням активності, тривалості і ремісії патологічного процесу. Тому доцільно провести подальші дослідження з вивчення ефективності багатокомпонентних пробіотичних препаратів при виявлених порушеннях мікробіоценозу у дітей.

Mema: дослідити стан мікробіоти товстого кишечника, визначити вплив хворобо-модифікуючих препаратів на мікрофлору у хворих на ЮРА та оцінити ефективність комбінованого синбіотику «Ротабіотик».

\section{Матеріал і методи дослідження}

Дослідження проводилось на базі кардіоревматологічного відділення Міської дитячої клінічної лікарні №1 м. Києва за протоколом, ухваленим локальним етичним комітетом установи, 3 дотриманням керівних принципів Гельсінської Декларації та після письмової інформованої згоди батьків дітей та самих пацієнтів старшого віку.

У дослідженні взяли участь 29 дітей віком від 1,5 до 16 років 3 діагнозом «Ювенільний ревматоїдний артрит», із середньою та низькою активністю процесу. Дебют захворювання становив від 6 міс. до 5 років (у середньому 1,9 року). Серед обстежених нами пацієнтів з ЮРА діагностована суглобова форма, олігоартрит із серонегативним варіантом у 14 (48,28\%); суглобова форма, поліартрит із серонегативним варіантом - у 13 (44,83\%); системно-суглобова форма, серопозитивний варіант - у 2 (6,9\%) дітей. У двох дітей з олігоартикулярною формою ЮРА виявлений увеїт. Найчастіше були уражені колінні суглоби - у 20 (69\%) дітей, рідше - гомілковостопні - у 8 (27,59\%), дрібні суглоби кистей і стоп - 4 (13,79\%), кульшові та променево-зап'ясткові - у 3 (10,34\%) хворих. Діти скаржились на біль, набряк та обмеження рухів в уражених суглобах, вранішню скутість.

При обстеженні шлунково-кишкового тракту у хворих мали місце наступні скарги: періо- дичний біль у животі - у 23 (79,31\%), зниження апетиту - у 20 (68,97\%), метеоризм - у 12 (41,38\%), схильність до запорів - у 10 (34,48\%) дітей.

На початку дослідження усім дітям проведено загальноклінічне та інструментальне обстеження: загальний аналіз крові, визначення у сироватці крові С-реактивного протеїну (якісного), ревматоїдного фактору, антистрептолізину-О, циркулюючих імунних комплексів, фібриногену, серомукоїду, кальцію іонізованого та ультразвукове дослідження суглобів за загальноприйнятими методиками.

Також усім дітям проведено бактеріологічне дослідження фекалій на початку дослідження та після корекції виявлених дисбіотичних порушень. Визначали кількісний (підрахунок колонієутворюючих одиниць (КУО)) та якісний мікробний склад товстого кишечника. Оцінка порушення мікробіоти кишечника здійснювалась відповідно до класифікації дисбіозу за І.Б. Куваєвою та К.С. Ладодо (1991 р).

На момент первинного обстеження усі діти отримували базисну протиревматичну терапію (метотрексат 15 мг/м²), глюкокотрикостероїди (преднізолон, метилпреднізолон) - 18 пацієнтів, біологічні хворобо-модифікуючі препарати (адалімумаб) - 5 хворих, додатково призначалось НПЗП коротким курсом (до 7 днів) 7 пацієнтам.

Корекція порушень мікробіоценозу кишечника проводилась комбінованим синбіотиком «Ротабіотик», до складу якого входять штами лактобактерій (Lactobaccillus bulgaricus, Lactobaccillus acidophilus), біфідобактерій - Bifidobacterium ssp. (B. bifidum, B. longum, B. infantis), а також Streptococcus thermophilus та пребіотик інулін 150 мг. В одній капсулі міститься 2,5 х 109 КУО ліофілізованих бактерій.

Основні функції пробіотичних біфідо-, лактокомпонентів:

1. Неімунологічні: участь у метаболічних процесах; продукція коротколанцюгових жирних кислот; сприяння травленню і конкуренція за поживні речовини з патогенами; адгезія до епітелію за рахунок наявності ворсинок; синтез бактеріоцинів; утворення молочної, оцтової кислоти, зміна рН для створення несприятливого середовища розвитку патогенних мікроорганізмів; стимуляція епітеліальної продукції муцину; підсилення кишкової бар'єрної функції.

2. Імунологічні: індукція продукції IL-10, IL-2, ФНП- $\alpha$, посилення вироблення Th-1 клітин та IL-1, стимуляція вироблення B-лімфо- 
цитів, нормалізація рівня прозапальних цитокінів, підвищення продукції IgA, як місцево, так і системно, активація локальних макрофагів; сприяння толерантності до харчових алергенів.

Функції інуліну:

1. Трофічна: вибіркова стимуляція проліферації власних корисних мікроорганізмів (біфідобактерій, лактобацил); є субстратом для життєдіяльності біфідогенних бактерій; служить джерелом для епітеліальних клітин слизової оболонки; зміщення рН фекалій у кислий бік; посилення перистальтики товстого кишечника; нормалізація випорожнень (зменшення їх щільності та збільшення кількості); зменшення частоти кольок, зригувань.

2. Імунна: взаємодія з рецепторами клітин імуногенезу (дендритними клітинами, Т-, В-лімфоцитами пеєрових бляшок); посилення синтезу протизапальних цитокінів (IL-10, секреторного IgA, Pg E2); вплив на активність натуральних кілерів, фагоцитарну активність макрофагів, $\gamma$-інтерферону, фактору некрозу пухлин; стимуляція Th-1 імунної відповіді (експериментальні дослідження при введенні вакцини); ефект прямого зв'язування патогенів.

3. Метаболічні ефекти: продукція коротколанцюгових жирних кислот, абсорбція іонів $\mathrm{Ca}, \mathrm{Fe}, \mathrm{Mg}$ та вітаміну Dз; посилення мінералізації кісткової тканини, іiі щільності, росту, резорбції та ремоделювання [5]; сприяння зниженню вмісту холестерину, глюкози крові та відкладення жиру; зниження рівня ліпопротеїдів у крові; покращення психічного здоров'я, когнітивного розвитку за рахунок впливу метаболітів на функцію головного мозку.

Таким чином, наявність пребіотика інуліну в складі синбіотика з пробіотичними штамами бактерій має перевагу та підсилюючу дію перед однокомпонентними пробіотиками.

Статистичну обробку результатів проведено за допомогою пакету програм Microsoft Excel 2010 та STATISTICA10.0.0.0.

\section{Результати дослідження та їх обговорення}

Усі діти були розподілені на три групи залежно від схеми лікування. До 1-ї групи увійшли діти, що отримували метотрексат $(\mathrm{n}=8)$, до 2-ї групи - метотрексат у комбінації з ГКС $(\mathrm{n}=16)$, до 3-ї групи - діти, які отримували метотрексат, ГКС та біологічні протиревматичні хворобо-модифікуючі препарати $(\mathrm{n}=5)$. Нестероїдні протизапальні препарати (вольтарен, нурофен) коротким курсом до 7 днів отримували 4 дитини.
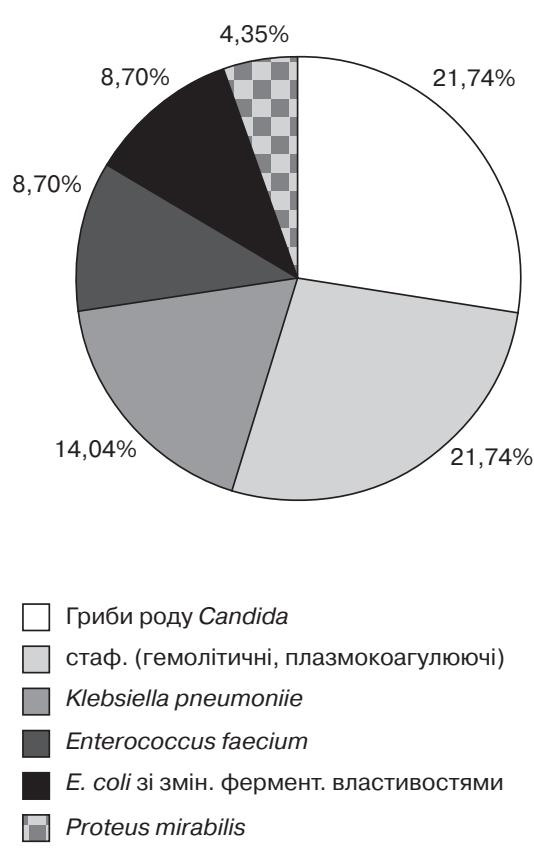

Pис. 1. Умовно-патогенна та патогенна мікрофрлора товстого кишечника у дітей з ЮРА

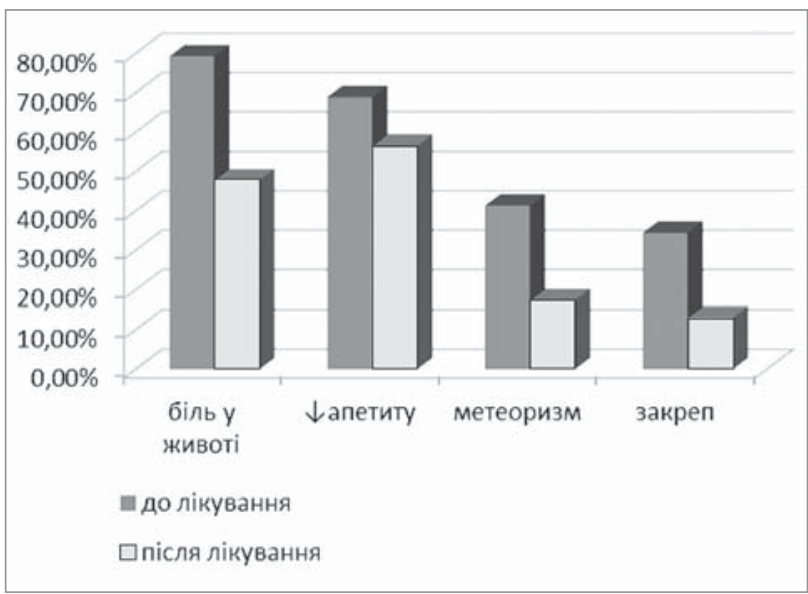

Pис. 2. Динаміка клінічної картини порушення дисбіозу товстого кишечника у дітей з ЮРА до та після застосування синбіотику (Ротабіотик)

У загальному аналізі крові обстежених дітей виявлено: підвищення кількості лейкоцитів до $10,1-11,6 \times 10^{9} /$ л (при нормі $4-9 \times 10^{9} /$ л) - у 4 пацієнтів, прискорення ШОЕ до 27-50 мм/год (норма 10-15 мм/год) - у 3 пацієнтів, анемію легкого ступеня - у 3 дітей, збільшення C-реактивного білка від + до +++ - у 5 пацієнтів. При УЗД уражених суглобів у 17 дітей виявлено ексудативно-проліферативний синовіїт: наявність рідини, розширення суглобової щілини, потовщання синовіальної оболонки.

При первинному бактеріологічному дослідженні калу 29 пацієнтів порушення дисбіозу товстого кишечника виявлено у 23 дітей, серед яких дисбіоз I ст. - у 8 (34,78\%), дисбіоз II ст. 
Стан мікробіоти товстого кишечника дітей до і після лікування

Таблиия

\begin{tabular}{|l|c|c|c|c|c|c|}
\hline \multirow{2}{*}{ Показник } & \multicolumn{2}{|c|}{ 1 група } & \multicolumn{2}{c|}{ 2 група } & \multicolumn{2}{c|}{ 3 група } \\
\cline { 2 - 7 } & до лікування & після лікування & до лікування & після лікування & до лікування & після лікування \\
\hline Порушень не виявлено & $3(37,50 \%)$ & $2(40 \%)$ & $2(12,5 \%)$ & $10(71,43 \%)$ & $1(20 \%)$ & $4(100 \%)$ \\
\hline I ст. & $1(12,5 \%)$ & $3(60 \%)$ & $5(31,25 \%)$ & $4(28,57 \%)$ & $2(40 \%)$ & - \\
\hline II Ст. & $3(37,5 \%)$ & - & $4(25 \%)$ & - & $2(40 \%)$ & - \\
\hline III Ст. & $1(12,5 \%)$ & - & $5(31,25 \%)$ & - & - & - \\
\hline
\end{tabular}

- у 9 (39,13\%), дисбіоз III ст. - у 6 (26,09\%) дітей. У всіх хворих відмічалось зменшення кількості лакто- та біфідобактерій $<10^{6}$ КУО, а також спостерігалося збільшення кількості умовно-патогенної та патогенної мікрофлори: гриби роду Candida (21,74\%), стафілококи (гемолітичні, плазмокоагулюючі 21,74\%), Klebsiella pneumoniie $(14,04 \%)$, Enterococcus faecium $(8,70 \%)$, E. coli зі зміненими ферментативними властивостями (8,70\%), Proteus mirabilis (4,35\%) (рис. 1).

Для корекції порушень мікрофлори призначали Ротабіотик: дітям віком від 1 до 3 років по 1 капсулі 1 раз на добу, дітям від 3 до 12 років - по 1 капсулі 2 рази на добу, дітям старше 12 років - по 1 капсулі 3 рази на добу. Тривалість застосування становила один місяць, після чого проводилось повторне бактеріологічне дослідження калу.

Результати досліджень показали позитивну динаміку клінічних симптомів захворювання за рахунок зменшення болю у животі з 79,31\% до $47,83 \%$, покращання апетиту у $43,48 \%$, зменшення проявів метеоризму з 41,38\% до 17,39\%, запорів - 3 34,48\% до 13,03\% (рис. 2).

При контрольному бактеріологічному дослідженні фекалій нормалізацію вмісту мікрофлори товстого кишечника виявлено у 16 (69,57\%) дітей. Дисбіотичні зміни I ст. зберігались у 7 (30,43\%) дітей, у яких на початку дослідження діагностовано дисбіоз II-III ст. ( $<0,001)$ (табл.)
Наведені дані свідчать, що використання Ротабіотика у комплексному лікуванні хворих на ЮРА є ефективним засобом корекції порушень мікробіоценозу товстого кишечника.

Скорочення тривалості лікування дисбіозу товстого кишечника у дітей з ЮРА за допомогою Ротабіотика є визначальним в оцінці фармако-економічного ефекту застосування мультикомпонентного синбіотика.

\section{Висновки}

1. У хворих на ЮРА на тлі лікування базисними протиревматичними препаратами, НПЗП та біологічними препаратами встановлено порушення мікробіоти товстого кишечника з розвитком дисбіозу різного ступеня за рахунок зменшення кількості нормальної мікробіоти та підвищення умовно-патогенної і патогенної мікрофлори, що ускладнює перебіг основного захворювання і погіршує якість життя.

2. Встановлений позитивний вплив синбіотика (Ротабіотик) на клінічні прояви диспептичного синдрому та відновлення складу бактеріального мікробіому у переважної більшості пацієнтів з ЮРА.

3. Запропонований синбіотик (Ротабіотик) є ефективним та безпечним засобом для корекції порушень мікробіоценозу товстого кишечника у хворих на ЮРА.

Автори заявляють про відсутність конфлікту інтересів.

\section{ЛITEPАТУРА}

1. Абатуров АЕ, Герасименко ОН. (2011). Хеликобактерная инфекция у детей: особенности диагностики и лечения. Здоровье ребенка 4(31): 93-95.

2. Абатуров АЕ, Герасименко ОН, Высочина ИЛ и соавт. (2013). Бактерицидная активность пробиотических средств. Здоровье ребенка 8(51): 95-97.

3. Валиева СИ, Алексеева ЕИ, Бзарова ТМ и соавт. (2008). Оценка эффективности препарата «Бифиформ» у больных ювенильным артритом, в условиях антибактериальной терапии. Вопросы современной педиатрии. 7(4): 109-114.
4. Жмылева ОС, Козлова ИВ, Мялина ЮН. (2012). Диагностическое значение изменений толстой кишки при ревматоидном артрите. Фундаментальные исследования. 7(2): 324-329.

5. Зайченко ОЕ. (2014). Пребиотики, пробиотики и синбиотики в профилактике остеопороза. Український терапевтичний журнал. 1: 85-94.

6. Захарова ЮВ. (2016). Факторы адгезии бифидобактерий. Журн Микробиол. 5: 80-87.

7. Каладзе НН, Филоненко ТГ, Сизова ОА. (2013). Особенности ультраструктурных изменений слизистой толстого кишечника при экспе- 
риментальном моделировании адьювантного артрита. Здоровье ребенка. 1(44): 18-21.

8. Лисенко ГІ, Білко ІП, Нікольська ОІ., Теслюк Л.В. (1999). Діагностика та лікування дисбактеріозу кишечнику у ревматологічних хворих. Метод. рекомендации. Київ: Знання: 22.

9. Меркулова А. (2016). Антибиотикотерапия, дисбактериоз и возможные риски. Здоров'я України - XXI сторіччя. 20: 72-73.

10. Муквич ЕН, Задорожняя ТД, Полук ТА, Людвик ТА. (2012). Ювенильный идиопатический артрит и иммунопатологическая роль нарушений микробиоты кишечника. Современная педиатрия. 3(43): 53-57.

11. Новокшонов АА, Мазанкова ЛН, Соколова НВ. (2002). Патогенетическое обоснование оптимальной терапии ОКИ у детей. Детские инфекции. 1: 32-37.

12. Петров АВ, Дударь ЛВ, Малый КД. (2004). Персистенция различных инфекционных агентов в мононуклеарных лейкоцитах крови в дебюте ревматоидного артрита. Терапевтический архив. 5: 32-35.

13. Фризен БН. (1995). Сравнительная эффективность базисной терапии ревматоидного артрита сульфопрепаратами (сульфасалазином, салазопиридазином, салазодиметоксином) и метотрексатом а также влияние лечения на микробиоценоз кишечника и морфологическую картину слизистой прямой кишки. Ягту: 60.

14. Челпаченко ОЕ, Бухарин ОВ, Данилова ЕИ, Федотова ЛП. (2015). Современные представления о роли микробного фактора в развитии воспалительных ревматических заболеваний. Вестник Уральской медицинской академии наук. 3: 73-80.

15. Чомахидзе АМ, Алексеева ЕИ. (2007). Прокальцитониновый тест в дифференциальной диагностике синдрома аллергосепсиса. Вопросы современной педиатрии. 6(2): 42-47.

16. Широбоков ВП, Янковський ДС, Димент ГС. (2009). Мікробна екологія людини з кольоровим атласом. Навч. посіб. Київ: Червона РутаТурс: 312

17. Янковский ДС, Дымент ГС. (2008). Микрофлора и здоровье человека. Киев: Червона Рута-Турс: 552.

18. Янковский ДС. (2005). Микробная экология человека: современные возможности ее поддержания и восстановления. Киев: Эксперт лТД: 362.
19. Abedi D, Feizizadeh S, Akbari V et al. (2013). In vitro antibacterial and antiadherence effects of Lactobacillus delbrueckii subsp bulgaricus on Escherichia coli. Res Pharm Sci. 8(4): 260-268.

20. Camp HJM, Oosterhof A, Veerkamp JH. (1985). Interaction of bifidobacterial lipoteichoic acid with human intestinal epithelial cells. Immunity. 1: 332-334.

21. Candela M., Biagi E., Centanni M et al. (2009). Bifidobacterial enolase, a cell surface receptor for human plasminogen involved in the interaction with the host. Microbiology. 155: 3294-3303.

22. Fanaro S, Chierici R, Guerrini P, Vigi V (2003). Intestinal microflora in early infancy: composition and development. Acta Paediatr. 91(441): 48-55.

23. Foroni E, Serafini F, Amidani D et al. (2011). Genetic analysis and morphological identification of pilus-like structures in members of the genus Bifidobacterium. Microb. Cell Factories. 10(1): 16-29.

24. Gonzales-Rodrigues I, Sanchez B, Ruiz L et al. (2012). Role of extracellular transaldolase from Bifidobacterium bifidum in mucin adhesion and aggregation. Appl. Environ. Mictobiology. 78(11): 3992-3998.

25. Kempsell KE, Cox CJ, Hurle M et al. (2000). Reverse transcriptase-PCR analysis of bacterial rRNA for detection and characterization of bacterial species in arthritis synovial tissue. Infect Immun. 68(10): 6012-26.

26. Mkrtchyan H, Gibbons S, Heidelberger S et al. (2010). Purification, characterization and identification of acidocin LCHV, an antimicrobial peptide produced by Lactobacillus acidophilus n.v. Er 317/402 strain Narine. Int J Antimicrob Agents. 35(3): 255-260.

27. Ohland CL, Macnaughton WK. (2010). Probiotic bacteria and ontestinal erithelial barrier function. Am J Physiol Gastrointest Liver Physiol.6:807-819.

28. Takeda T, Mizugaki Y, Matsubara L et al. (2000). Lytic Epstein-Barr virus infection in the synovial tissue of patients with rheumatoid arthritis. Arthritis Rheum.43(6):1218-1225.

29. Vaahtovuo J, Munukka E, Korkeamaki M et al. (2008). Fecal Microbiota in Early Rheumatoid Arthritis. J of Rheumatol. 35(8):1500-1505.

30. Wei X, Yan X, Chen X et al. (2014). Proteomic analysis of the interaction Bifidobacterium longum NCC2705 with the intestine cells Caco-2 and identification of plasminogen receptors. J. Proteomics. 108:89-98.

\section{Сведения об авторах:}

Бережной Вячеслав Владимирович - д.мед.Н., проф. каф. педиатрии № 2 НМАПО имени П.Л. Шупика. Адрес: г. Киев, ул. Боготырская, 30; тел. (044) 412-16-70. Бондарец Юлия Ивановна - аспирант каф. педиатрии №2 НМАПО имени П.Л. Шупика. Адрес: г. Киев, ул. Богатырская, 30; тел. (044) $412-16-70$. Статья поступила в редакцию 21.11.2018 г.; принята в печать 24.02.2019 г. 


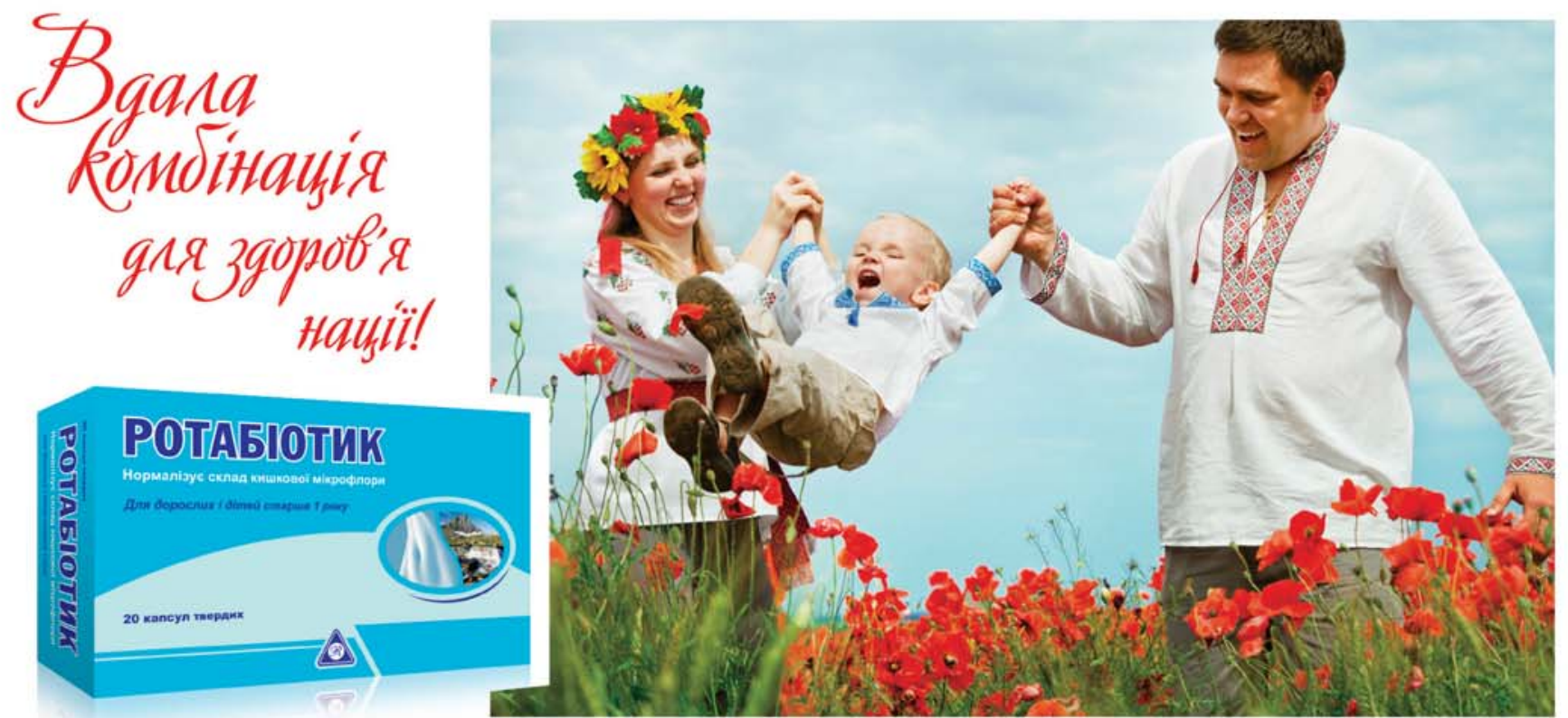

від 1 року

20 капсул

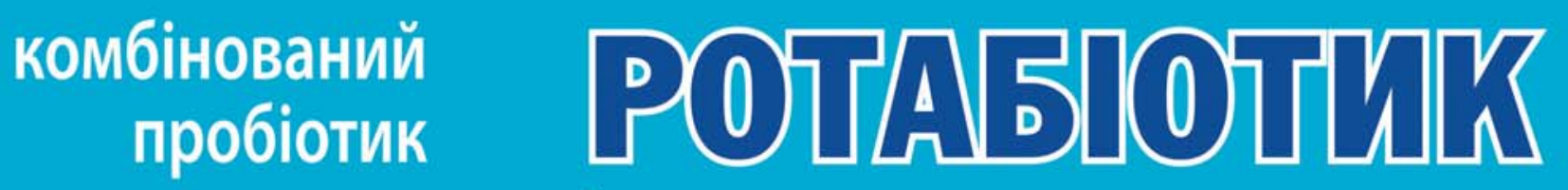

Завдяки комбінації лакто-, біфідобактерій та інуліну РОТАБІОТИК проявляє підвищену ефективність порівняно із продуктами, що містять один вид бактерій

Живі лакто- та біфідобактерії

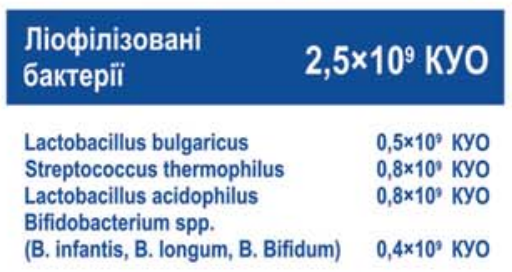

1 О Оптимізує функції організму

1 Нормалізує склад кишкової мікрофлори, в т. ч. під час та після лікування антибіотиками та іншими лікарськими засобами

1 Поліпшує травлення

1 Сприяє підвищенню імунітету

I Запобігає розвитку алергійних станів

\section{Інулін 150,0 мг}

ІНУЛІН являє собою пребіотик, так як є найкращим живильним середовищем для корисних лактоі біфідобактерій в кишечнику.'

ІНулІН здатен знижувати рівень холестерину та глюкози в крові, замінюючи їі натуральною фруктозою.' ІнулІн зміцнює імунну систему, підвищує опірність організму до патогенних мікроорганізмів і вірусів.' 


\section{Державний експертний центр Міністерства охорони здоровя України ГС «Українська Академія Педіатрічних спеціальностей» Медична мережа «Добробут»}

\section{Гострий обструктивний ларингіт (круп) у дітей}

\section{Адаптована клінічна настанова, заснована на доказах}

Робоча група з адаптації клінічної настанови:

\begin{tabular}{|l|l|}
\hline Ліщишина Олена Михайлівна & $\begin{array}{l}\text { директор департаменту стандартизації медичних послуг Державного підприємства } \\
\text { «ержавний експертний центр МОЗ України», к.мед.н., с.н.с., заступник голови } \\
\text { робочої групи з методології }\end{array}$ \\
\hline Риков Олексій Аркадійович & $\begin{array}{l}\text { керівник групи, медичний директор з педіатрії ММ «Добробут», лікар-педіатр } \\
\text { вищої категорії }\end{array}$ \\
\hline Горбачова Марина Миколаївна & $\begin{array}{l}\text { завідувач педіатричного відділення Відокремленого структурного підрозділу } \\
\text { №2 ТОВ МЦ «Добробут Поліклініка», лікар-педіатр }\end{array}$ \\
\hline Роля Сергій Миколайович & лікар-оториноларинголог дитячий та дорослий ММ «Добробут» \\
\hline Мартинова Валерія Віталіївна & лікар-педіатр, дитячий гематолог ММ «Добробут» \\
\hline Саволюк Олена Іванівна & лікар-педіатр ММ «Добробут» \\
\hline \hline
\end{tabular}

Методичний супровід та інформаційне забезпечення

Державний експертний центр Міністерства охорони здоров'я України є членом

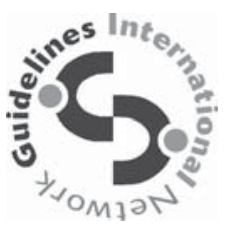

Guidelines International Network

(Міжнародна мережа настанов)

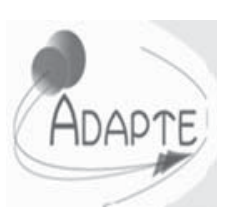

ADAPTE (Франція)

(Міжнародний проект з адаптації клінічних настанов)

Перегляд клінічної настанови заплановано на 2021 рік

Перелік скорочень

ЛТБ - ларинготрахеобронхіт

НПЗП - нестероїдні протизапальні препарати

ЦНС - центральна нервова система

ШВЛ - штучна вентиляція легень

RSV - респіраторно-синцитіальний вірус

Передмова мультидисциплінарної робочої групи з адаптащї̈ клінічної настанови. Синтез даних

Дана клінічна настанова є адаптованою для системи охорони здоров'я Украӥни версією клінічних рекомендацій Diagnosis and Management Croup clinical Practice guideline (January 2008) Toward Optimized Practice, що були обрані робочою групою як приклад найкращої практики надання медичної допомоги пачієнтам з гострим стенозуючим ларинготрахеїтом, $і$ грунтується на даних доказової медицини стосовно ефективності та безпеки медичних втручань, фармакотерапіі та організащійних принщипів ї̈ надання.

Окремі розділи настанови, зокрема питання епідеміології, діагностики та лікування, доповнені фрагментами з Acute Management of Croup in Emergency Department Canadian Paediatric Society (May 2017) ma Consensus guidelines for management of Croup (Nothern California Pediatric Hospatal Medicine Consortium, 2016). 
Деякі аспекти лікування запозичені з Pediatric Advanced Life Support 2015 (American Heart Association).

Запропонована адаптована клінічна настанова не повинна розцінюватись як стандарт медичного лікування. Дотримання положень клінічної настанови не гарантуе успішного лікування в кожному конкретному випадку, ї не можна розглядати як посібник, що включає всі необхідні методи лікування або, навпаки, виключає інші. Остаточне рішення стосовно вибору конкретної клінічної процедури або плану лікування повинен приймати лікар з урахуванням клінічного стану пацієнта та можливостей для проведення заходів діагностики і лікування у медичному закладі. Адаптована клінічна настанова «Гострий стенозуючий ларинготрахеїт», відповідно до свого визначення, має на меті надання допомоги лікарю і пацієнту в прийнятті раціонального рішення в різних клінічних ситуаціях, слугує інформаційною підтримкою щодо найкращої клінічної практики на основі доказів ефективності застосування певних медичнх технологій, ліків та організачійних засад медичної допомоги.

Переклад здійснено за допомогою ГО М-Gate

\section{Вступ}

«Acute management of croup in the emergency department» (Canadian Paediatric Society, 2017)

\section{Етіологія та патогенез}

Круп викликається вірусними інфекціями дихальних шляхів, найчастіше - вірусом парагрипу типу 1 і 3. Інші можливі збудники: вірус грипу типу А та В, аденовірус, респіраторно-синцитіальний вірус (RSV) та метапневмовірус. Ці інфекції викликають генералізоване запалення дихальних шляхів та набряк слизової оболонки верхніх дихальних шляхів. Нижній відділ глотки звужується, викликаючи обструкцію верхніх дихальних шляхів та симптоми, що зазвичай пов'язані з крупом.

«Diagnosis and management of croup» (Clinical Practice Guideline, Toward optimized practice, 2008)

\section{Епідеміологія}

Круп (ларинготрахеобронхіт) є дуже поширеною причиною обструкції верхніх дихальних шляхів у дітей - щорічна захворюваність дітей у віці до шести років становить $6 \%$ [26]. Круп найчастіше зустрічається у період від пізньої осені до початку зими, але може виникати цілий рік. Круп, як правило, викликається вірусом парагрипу, однак причиною можуть бути інші віруси [27,28].

Круп найчастіше зустрічається у дітей у віці від шести місяців до трьох років, але може також зустрічатися у дітей віком від трьох місяців до 15 років [1]. Хлопчики хворіють на круп частіше, ніж дівчатка. Повідомляється, що круп рідко зустрічається у дорослих. Основною причиною занепокоєння батьків та лікарів є питання респіраторної підтримки, проте переважна більшість дітей може безпечно лікуватись вдома, адже частка тих, хто вимагає штучної підтримки прохідності дихальних шляхів, дуже мала. Більше $60 \%$ дітей, у яких діагностовано наявність крупу, мають легкі симптоми, близько 4\% госпіталізуються і приблизно одній дитині із 4500 виконують інтубацію (приблизно один зі 170 госпіталізованих хворих) [2,28,30].

Коментар робочої групи. Звичним терміном для України (синонімом «крупу») $\epsilon$ «гострий стенозуючий ларинготрахеїт» (ГСЛТ), проте він не відображає патогенез захворювання та не відповідає Міжнародній класифікащії хвороб (МКХ).

\section{Диференціальна діагностика}

Переважна більшість дітей, які страждають на гострий перебіг обструкції верхніх дихальних шляхів, що супроводжується явищами стридору та втягненням грудної клітки, мають круп. Загалом, діагноз «Круп» є правильним, проте рідкісні, але проблемні, причини стридору також повинні бути розглянуті та виключені. 


\section{Бактеріальний трахеїт}

Найбільш поширеним альтернативним діагнозом є бактеріальний трахеїт - серйозна, потенційно небезпечна для життя, бактеріальна інфекція, причиною якої, як вважається, є розвиток суперінфекції при крупі [15-18]. Цю хворобу найбільш важко відрізнити від крупу. Бактеріальний трахеїт, як правило, проявляється раптовим погіршенням стану після епізоду крупу легкої чи середньої важкості. Його найлегше відрізнити від крупу за наявністю гострої появи високої температури, інтоксикації та поганої відповіді на епінефрин [17]. Наявність густого трахеального мокротиння при бактеріальному трахеїті потенційно може викликати оклюзію дихальних шляхів. Ведення бактеріального трахеїту включає внутрішньовенні антибіотики широкого спектра, а також постійний моніторинг стану дихальних шляхів, оскільки часто виникає необхідність інтубації та підтримки органів дихання.

\section{Епіглотит}

Другим найбільш імовірним альтернативним діагнозом є епіглотит. Це захворювання, перш за все викликане гемофільною інфекцією, колись було досить поширеним у дітей, проте, з появою НІВ-вакцини, наразі є відносно рідкісним. У дитини з епіглотитом найчастіше спостерігається раптове настання високої температури, дисфагії, слинотечі, інтоксикації, збудження і сидіння в «положенні для інтубації». Гавкаючий кашель відсутній. Найважливішим аспектом лікування $є$ захист дихальних шляхів, і він має проводитись тільки лікарями, які мають великий досвід роботи 3 дихальними шляхами. Будь-яка дитина 3 підозрою на епіглотит повинна бути доставлена «швидкою» у лікарню у супроводі лікаря, який має кваліфікацію в лікуванні патології дитячих дихальних шляхів.

Діти з крупом у віці до 6 місяців або з тривалими чи надзвичайно важкими симптомами потребують подальшої оцінки для виключення вродженого чи набутого звуження дихальних шляхів [1]. Довготривалі симптоми крупу одночасно з лихоманкою можуть спостерігатися при вторинній бактеріальній інфекції [1]. Менш ніж 1\% дітей з крупом мають серйозні чи загрозливі для життя симптоми [1,2], але є декілька інших небезпечних для життя станів, що можуть супроводжувати стридор. Інтоксикація, слинотеча та дисфагія є важливими «червоними прапорцями», що супроводжують більш серйозні стани (табл. 1).

Коментар робочої групи. Враховуючи вкрай низький рівень вакиинації в Україні від дифтерій, необхідно проводити диференціальну діагностику з даним захворюванням $і$ в разі виникнення підозри на дифтерію - призначити бакпосів на BL.

Типовими симптомами дифтерії є: гострий початок, температура субфебрильна або фебрильна, наявність плівчастого або фібринозного нальоту на мигдаликах, біль у горлі помірний, що не відповідає характеру і поширеності процесу, регіонарний підщелепний або шийний лімфаденіт, набряк підшкірно-жирової клітковини шиї різного поширення, епідеміологічні дані - контакт з хворим на дифтерію, порушення календаря щеплень проти дифтерії.

Диференціальний діагноз

Таблиия 1

\begin{tabular}{|l|l|}
\hline \multicolumn{1}{|c|}{ Стан } & \multicolumn{1}{c|}{ Характеристика } \\
\hline Бактеріальний трахеїт & $\begin{array}{l}\text { Висока температура, інтоксикація та слабка відповідь на інгаляції } \\
\text { епінефрину }\end{array}$ \\
\hline $\begin{array}{l}\text { Ретрофрарингеальний, парафарингеальний, } \\
\text { перитонзилярний абсцеси }\end{array}$ & $\begin{array}{l}\text { Висока температура, біль у шиї, біль у горлі та дисфрагія, що супроводжу- } \\
\text { ються кривошиюю, слинотечею, дихальним дистресом та стридором }\end{array}$ \\
\hline Епіглотит & $\begin{array}{l}\text { Відсутність гавкаючого кашлю, раптова поява високої температури, дисфра- } \\
\text { гія, слинотеча, інтоксикація, неспокій та положення із витягнутою та зігну- } \\
\text { тою шиєю («положення для інтубації») }\end{array}$ \\
\hline Аспірація чи проковтування стороннього тіла & $\begin{array}{l}\text { «Крупозний» кашель, епізоди ядухи, хрипи, осиплість, двосразний стридор, } \\
\text { задишка та зниження об'єму вдиху }\end{array}$ \\
\hline $\begin{array}{l}\text { Гостра алергічна реакція (анафрілаксія чи } \\
\text { ангіоневротичний набряк) }\end{array}$ & $\begin{array}{l}\text { Швидкий розвиток дисфагії, хрипів, стридору; можлива поява шкірних } \\
\text { проявів алергії, таких як уртикарна висипка }\end{array}$ \\
\hline
\end{tabular}

Адаптовано з Bjornson та Johnson [9]. 


\section{Патогенез та патофізіологія}

Вірусна інфекція слизової оболонки гортані спричиняє запалення, гіперемію, набряк, некроз епітелію та його злущення [33], це призводить до звуження надглоткової ділянки. Діти компенсують звуження верхніх дихальних шляхів, дихаючи більш швидко і глибоко. По мірі того, як звуження прогресує, дитина збільшує зусилля для дихання, що стає непродуктивним. Потік повітря через верхні дихальні шляхи стає турбулентним (стридор), і піддатлива грудна клітка починає «втягуватись» під час вдиху. Це призводить до неефективного асинхронного руху грудної і черевної порожнин, дитина виснажується. У цей момент наростає гіпоксія і гіперкапнія та швидко розвивається дихальна недостатність і зупинка дихання [34,35].

Гострий ЛТБ найчастіше обумовлений різноманітними вірусними агентами та іноді Mycoplasma pneumoniae [1]. Парагрип типу $1 \in$ найпоширенішою причиною крупу у Північній Америці, а друга з найбільш частих причин - парагрип типу 3 [36]. Також виділялись грип А і В, аденовірус, респіраторно-синцитіальний вірус (RSV), метапневмовірус людини, коронавірус, еховірус та мікоплазма. Рідко патогенами бувають ентеровірус, кір, паротит, риновірус та Corynbacterium diphtheriae.

\section{Клінічна картина}

Симптоми крупу зазвичай представлені неспецифічним кашлем, нежитем та лихоманкою. Специфічний гавкаючий кашель, стридор та дихальний дистрес частіше розвиваються раптово протягом вечора або вночі, але іноді можуть розвиватись поступово протягом дня. Стридор, як правило, виникає тільки під час вдиху, але при більш серйозному дистресі може бути двофазним, що виникає і в період видиху. Може виникати лихоманка до $40^{\circ} \mathrm{C}$.

Симптоми зазвичай набагато сильніші вночі та зменшуються протягом дня. У більшості дітей 3 крупом обструктивні симптоми зникають протягом 48 годин, хоча невеликий відсоток дітей має симптоматику протягом п'яти-шести днів [3]. Хоча поява дихальної недостатності часто є раптовою, вона рідко розвивається негайно, тобто протягом декількох хвилин.

Дихальна недостатність зазвичай виникає протягом декількох годин. Ознаки дихальної недостатності та загрози зупинки дихання включають зменшення дихальних рухів, млявість, блідість та потемніння шкіри.

\section{«Consensus guidelines for management of Croup» (Nothern California Pediatric Hospatal Medicine Consortium, 2016)}

Необхідно подумати про альтернативний діагноз, якщо:

- вік дитини <6 місяців або >6 років;

- повторний епізод крупу протягом 1 місяця

- стридор триває більше 4-х днів та кашель більше 10 днів

- відсутній ефект від стандартної терапії

- симптоми інтоксикаціїі

- асиметрія дихання.

«Diagnosis and management of croup» (Clinical Practice Guideline, Toward optimized practice, 2008)

Багато медичних експертів виділяють кілька типів крупу. Найбільш поширений поділ на гострий ЛТБ (ГЛТБ) та спазматичний круп. Гострий ЛТБ описується як хвороба, при якій діти мають вірусний продром (неспецифічний кашель, нежить та лихоманку) протягом 12-48 годин, тоді як спазматичний круп описується як хвороба, при якій симптоми виникають гостро, без вірусного продрому [33]. Останній тип крупу не характеризується підвищенням температури, а симптоми є більш тривалими, ніж у дітей з ГЛТБ. Діти зі спазматичним крупом також схильні до рецидивних епізодів. Хоча ці типи крупу, як правило, описані в медичних підручниках, не існує добре організованих когортних досліджень, що підтверджують відмінності або клінічну важливість внесення цього поділу.

Ступінь респіраторного дистресу дитини при зверненні у відділення невідкладної допомоги має бути оцінений згідно з настановами (табл. 2). Клінічна оцінка, використана у дослідженнях, не продемонструвала покращення лікування [10,11]. Більшість клініцистів характеризують рес- 


\section{Важкість крупу}

Таблиия 2

піраторний дистрес як легку, помірну, важку чи загрозливу дихальну недостатність. Використовуючи цю класифікацію, експертним консенсусом був розроблений алгоритм амбулаторного лікування крупу у дітей [12]. Дітям, що мають серйозний дистрес чи загрозу дихальної недостатності, слід звернутися до педіатричного відділення інтенсивної терапії чи анестезіологічного відділення для надання відповідної допомоги, якщо відповідь на початкове лікування є слабкою чи не спостерігається. Ступінь респіраторного дистресу дитини при зверненні у відділення невідкладної допомоги має бути оцінений згідно з настановами (табл. 2). Клінічна оцінка, використана у дослідженнях, не продемонструвала покращення лікування [10,11]. Більшість клініцистів характеризують респіраторний дистрес як легку, помірну, важку чи загрозливу дихальну недостатність. Використовуючи цю класифікацію, експертним консенсусом був розроблений алгоритм амбулаторного

CNS Central nervous system. Змінено з Bjornson ma Johnson [1]

лікування крупу у дітей [12]. Дітям, що мають серйозний дистрес чи загрозу дихальної недостатності, слід звернутися до педіатричного відділення інтенсивної терапії чи анестезіологічного відділення для надання відповідної допомоги, якщо відповідь на початкове лікування є слабкою чи не спостерігається.

Коментар робочої групи. Ступені важкості крупу відповідають ступеням важкості респіраторного дистресу. Загроза дихальної недостатності - клініко-лабораторний стан, що характеризується такими показниками газового складу крові, як $\mathrm{PO}_{2}, \mathrm{PCO}$, pH, ВЕ та іншими.

\section{Лабораторні та інструментальні дослідження}

\section{8)}

«Diagnosis and management of croup» (Clinical Practice Guideline, Toward optimized practice,

× Лабораторні та радіологічні дослідження НЕ $€$ Необхідними для постановки діагнозу крупу. Діагноз можна достовірно встановити на підставі клінічної картини у поєднанні 3 історією хвороби та фізикальним оглядом.

× Необхідно відкласти будь-які грунтовні дослідження на час знаходження пацієнта у стані респіраторного дистресу.

× Для пацієнтів з типовою клінікою, які відповідають на лікування, візуалізаційні методики HE $€$ Необхідними. Проте знімки шиї у латеральній та передньо-задній проекціях можуть допомогти у встановленні діагнозу дітям із симптомами, подібними до крупу.

x Конусоподібне звуження надглоткової ділянки замість нормального вигляду свідчить про круп.

× Передньо-задня рентгенографія шиї може бути корисною для встановлення діагнозу па цієнтам з атиповою клінікою [6]. Наступні радіологічні знахідки вказують на такі альтернативні захворювання:

- розірваний край або мембрана, що охоплює трахею, свідчить про бактеріальний трахеїт;

- потовщання надгортанника та навколишніх складок свідчить про наявність епіглотиту;

- випинання заглоткових м'язових тканин вказує на ретрофарингеальний абсцес.

Якщо рентгенографія все ж проводиться:

- прогресування обструкції дихальних шляхів може бути швидким, тому під час проведення обстеження пацієнти мають бути під спостереженням медичного персоналу, навченого роботі з дитячими дихальними шляхами;

- протипоказана, якщо є клінічна підозра на епіглотит або бактеріальний трахеїт, оскільки маніпулювання шиєю або переміщення дитини може призвести до збільшення обструкції дихальних шляхів [4].

× Пульсоксиметрія показана у дітей з помірним або важким крупом (див. табл. 1). Іноді діти без важкого крупу можуть мати низьку сатурацію через наявність внутрішньолегеневого 
ураження [7].

\begin{tabular}{|c|c|c|c|c|}
\hline Ознака & Легкий & Середній & Важкий & $\begin{array}{c}\text { Загроза дихальної } \\
\text { недостатності }\end{array}$ \\
\hline Гавкаючий кашель & Час від часу & Часто & Часто & $\begin{array}{c}\text { Часто не відмічається } \\
\text { через виснаження }\end{array}$ \\
\hline Стридор & $\begin{array}{c}\text { Немає чи мінімальний } \\
\text { у стані спокою }\end{array}$ & $\begin{array}{l}\text { Легко чується } \\
\text { у стані спокою }\end{array}$ & $\begin{array}{c}\text { Значний на вдиху та } \\
\text { періодичний на видиху }\end{array}$ & $\begin{array}{c}\text { Чутний у спокої, але може } \\
\text { бути тихим чи погано } \\
\text { вислуховуватись }\end{array}$ \\
\hline $\begin{array}{l}\text { Втягнення надгрудинного } \\
\text { та міжреберних проміжків }\end{array}$ & Немає & $\begin{array}{l}\text { Видиме у стані } \\
\text { спокою }\end{array}$ & $\begin{array}{c}\text { Відмічається або } \\
\text { серйозне }\end{array}$ & Може не відмічатись \\
\hline $\begin{array}{l}\text { Втома, збудження чи } \\
\text { летаргія (гіпоксія ЦНС) }\end{array}$ & Немає & $\begin{array}{l}\text { Немає чи } \\
\text { обмежена }\end{array}$ & $\begin{array}{c}\text { Може бути присутня } \\
\text { значна летаргія }\end{array}$ & $\begin{array}{c}\text { Летаргія чи зниження } \\
\text { рівня свідомості }\end{array}$ \\
\hline Ціаноз & Немає & Немає & Немає & $\begin{array}{c}\text { Блідість чи ціаноз без } \\
\text { подачі додаткового кисню }\end{array}$ \\
\hline
\end{tabular}

× Пульсоксиметрія НЕ $€$ НЕОБХІДНОЮ у пацієнтів з легким крупом (див. табл. 1).

$\times$ Виявлення вірусних культур або швидкі антигенні тести НЕ Є КОРИСНИМИ у плановому обстеженні, особливо під час епідемічного періоду.

«Acute management of croup in the emergency department» (Canadian Paediatric Society, 2017)

Консультація оториноларинголога (ЛОР) для оцінки стану дихальних шляхів рекомендується у випадку стабільно важких симптомів крупу, які не реагують на проведене лікування. Амбулаторна консультація ЛОРа рекомендована дітям з кількома епізодами крупу та тим, що виходить за межі звичайної вікової групи типового крупу.

«Diagnosis and management of croup» (Clinical Practice Guideline, Toward optimized practice, 2008)

\section{Терапія}

\section{Зволоження}

Дітей $з$ крупом лікували вологим повітрям більше сотні років, починаючи з використання «крупових інгаляторів». Проте немає жодних доказів ефективності їх використання [8]. Систематичний огляд не виявив істотних відмінностей важкості крупу, який лікували за допомогою зволоження повітря [8]. Після цього систематичного огляду було опубліковане наступне рандомізоване контрольоване дослідження, у якому 140 хворих дітей з помірним або важким крупом лікувались у відділенні невідкладної допомоги. У дослідженні порівнювали лікування інсуфляцією зволоженим киснем (вважалось за плацебо, оскільки цей метод доставки кисню за вологістю дорівнював атмосферному повітрю) з двома іншими методами, що включали $40 \%$ та 100\% зволожений кисень. Отримані дані не показали суттєвої користі від зволоження не було відмінностей у важкості крупу, частоті госпіталізації до лікарні, потребі у додатковій медичній допомозі або лікуванні епінефрином чи дексаметазоном у групах [9]. Не отримано доказів про користь кисневих інгаляторів, зволожувачів для спальних місць, а також кисневих палаток. Зокрема, палатки з киснем не повинні використовуватися, оскільки вони створюють незручне, вологе, холодне, «обмежене» середовище, відокремлюють дитину від батьків, а також призводять до збудження дитини [37]. Крім того, кисневі палатки часто неправильно очищуються між використаннями і можуть бути джерелом інфекції у кімнаті дитини.

\section{Кисень}

Кисень слід призначати лише дітям з гіпоксією (якщо сатурація дитини у кімнаті без подачі кисню менше, ніж 92\%) та серйозними респіраторними розладами. Кисень ніколи не можна застосовувати у дитини, яка сильно збуджена. «Інсуфляція» (подача кисню через пластиковий шланг з кінцевим отвором, що тримається поруч із носом і ротом дитини) часто є найбільш прийнятним способом введення кисню.

Гелієво-киснева суміш

Введення гелію дітям з крупом було запропоновано у зв'язку з його нижчою щільністю (порівняно з азотом), що надає потенціал у зменшенні турбулентності потоку повітря у звужених 
дихальних шляхах. Сучасних доказів недостатньо для загального застосування гелію при веденні крупу [38-42].

Систематичний огляд даних трьох рандомізованих клінічних досліджень [43] показав, що геліокс (суміш кисню та гелію) може мати короткочасну користь у дітей з помірним або важким крупом, які отримували терапію кортикостероїдами. Зверніть увагу, що геліокс повинен вводитись досвідченим персоналом і має обмеження, наприклад те, що співвідношення гелію до кисню 70:30 дорівнює найменшому вмісту кисню при вдиху, що можна давати пацієнту.

Фармакотерапія (див. дод. 2)

Анальгетики/Антипіретики. Не існує опублікованих контрольованих досліджень, що підтримують застосування анальгетиків або жарознижувальних засобів для лікування дітей 3 крупом, однак зменшення температури і болю має забезпечити більш комфортний стан дитини.

Протикашльові та протизапальні засоби. Не існує опублікованих досліджень, що підтверджують використання і потенційну користь протикашльових та протизапальних засобів для дітей з крупом. Крім того, немає клінічного підгрунтя для їх використання, тому їх не слід вводити або рекомендувати.

Антибіотики. Не існує опублікованих контрольованих досліджень, які демонструють потенційну користь антибіотиків у дітей з крупом. Оскільки круп практично завжди є вірусною інфекцією, емпірична антибіотикотерапія не рекомендується. Крім того, поширеність суперінфекції у дітей з крупом (найчастіше це бактеріальний трахеїт та інколи - пневмонія) настільки рідкісне (менше ніж у 1 з 1000), що застосування антибіотика для «профілактики» також недоцільне.

Бета-2 агоністи. 3 огляду на те, що круп є хворобою верхніх дихальних шляхів, відсутні фізіологічне підгрунтя та докази, що підтримували б використання бета-2 агоністів для його лікування.

Коментар робочої групи. Згідно з чинним наказом МОЗ України №437 від 31.08.2004 «Про затвердження клінічних Протоколів надання медичнӧ допомоги при невідкладних станах у дітей на шпитальному $і$ дошпитальному етапах», розглядається застосування місчевих відволікаючих прощедур (сухе тепло на шию, зігрівання міжлопаткової ділянки, литкових м'язів, п'ят) для крупу першого ступеня важкості, а також антигістамінних препаратів для крупу другого-четвертого ступеня важкості, седативних препаратів, заходів щодо стимуляиіӥ діурезу зі скороченням добових надходжень рідини до 80\% фізіологічної потреби. Слід зазначити, що вказані рекомендащії не мають відповідного рівня доказовості та суперечать визнаним у світі міжнародним рекомендаціям.

Eniнефрин. Згідно з історичними даними, епінефрин, призначений дітям з важким крупом, суттєво зменшує кількість проведень ШВЛ [44]. Відомо, що епінефрин істотно знижує дихальний дистрес протягом 10 хвилин після введення і діє більше години [22,45-50]. Ефект епінефрину зникає протягом двох годин після введення. Пацієнти, які отримували епінефрин, повертаються до «базової» важкості стану, але більш серйозні симптоми зазвичай не розвиваються («ефект відскоку») [22]. Було опубліковано ряд ретроспективних та проспективних досліджень, які вказують на те, що пацієнти, які отримували епінефрин, можуть бути безпечно виписані додому, якщо їх симптоми не повторюються принаймні через дві-три години після лікування [11,12,23-25,51]. Систематичний огляд даних з восьми рандомізованих контрольованих клінічних випробувань показав, що лікування небулайзерним епінефрином було пов'язане з поліпшенням стану протягом 30 хвилин після введення, а тривалість перебування у лікарні дітей, яких госпіталізували з крупом, була меншою у групі, що лікувалась небулайзерним епінефрином [5].

Рацемічна форма епінефрину традиційно застосовувалася для лікування пацієнтів з крупом; у Північній Америці рацемічна форма епінефрину більше недоступна. Однак епінефрин у розведенні 1:1000 порівняно ефективний і так само безпечний, як і рацемічна форма [10]. У всіх дітей, незалежно від ваги, застосовують одноразову дозу (0,5 мл 2,25\% рацемічного епінефрину та 5,0 мл епінефрину 1:1000). Вважається, що відносний розмір дихального об'єму, що є змінним у дітей, модулює дозу препарату, фактично доставленого до верхніх дихальних шляхів. 
Як повідомляється, тривала терапія епінефрином використовується в деяких педіатричних відділеннях інтенсивної терапії. Проте в одній із статей повідомлялося про «звичайну» дитину 3 важким крупом, котру лікували трьома інгаляціями епінефрину протягом однієї години. У дитини розвинулась шлуночкова тахікардія та інфаркт міокарда [52]. Отже, повторні дози епінефрину ніколи не слід використовувати, якщо немає загрози розвитку дихальної недостатності. За необхідності тривалої терапії лікар повинен якнайшвидше зв'язатися 3 педіатром-інтенсивістом щодо подальшого лікування та транспортування.

\section{«Consensus guidelines for management of Croup» (Nothern California Pediatric Hospatal Medicine Consortium, 2016)}

L-епінефрин може бути застосований замість рацемічного розчину епінефрину у закладах, де рацемічний розчин епінефрину недоступний.

\section{«Pediatric Advanced Life Support» (American Heart Association, 2015).}

Разова доза L-епінефрину для інгаляцій становить:

для дітей $<4$ років $-2,5$ мл

для дітей $>4$ років -5 мл.

\section{«Diagnosis and management of croup» (Clinical Practice Guideline, Toward optimized practice, 2008)}

Глюкокортикоїди. Стероїди є основою терапії крупу, з огляду на те, що у нещодавньому систематичному огляді 38 рандомізованих контрольованих досліджень, у тому числі понад 4000 пацієнтів, попередніх метааналізів та вибіркових рандомізованих контрольованих досліджень було продемонстровано, що кортикостероїди зменшують кількість і тривалість інтубації, неохідності реінтубації, зменшують рівень та тривалість госпіталізації та зменшують кількість візитів до лікаря через стійкі симптоми крупу [51,53-56].

Велике багатоцентрове канадське дослідження, в якому взяли участь 720 дітей з легким крупом, показало, що у дітей, які отримували дексаметазон, у порівнянні з плацебо було наполовину менше повторних звернень до лікаря (7\% проти 15\%), суттєво менш важкий перебіг крупу і більший час сну у перші 48 годин після лікування. Крім того, їхні батьки зазнали меншого стресу у перші 24 години після лікування, а сім'ї та система охорони здоров'я зазнали трохи менше витрат - в середньому $21 \$$ на дитину [54]. Ці переваги були подібними у дітей із дуже слабкими симптомами (лише гавкаючий кашель) та тих, хто мав симптоми крупу протягом кількох днів під час дослідження. Не було жодних побічних ефектів у кожній групі лікування. Тому всім дітям, у яких діагностовано наявність крупу (про що свідчить гавкаючий кашель), слід лікуватись кортикостероїдами, за рідкісним винятком - дитина з відомим імунодефіцитом або нещодавнім контактом з вітряною віспою.

Дексаметазон є однаково ефективним при пероральному та парентеральному введенні $[57,58]$. Однак перевагу має пероральне введення, оскільки воно, як правило, менш травматичне. Дексаметазон перорально (з використанням парентеральної/ін'єкційної форми препарату, змішаної з ароматизованим сиропом) швидко абсорбується, менш ніж у 5\% дітей виникає блювання [59,60]. Покращення розвивається протягом 1-3 годин і зберігається 24-48 годин після введення однієї дози [53,61].

Коментар робочої групи. Станом на січень 2018 року в Україні дексаметазон зареєстрований у наступних лікарських формах: розчин для парентерального введення, таблетована форма; що унеможливлюе застосування дексаметазону перорально у дітей молодшої вікової групи та немовлят.

Звичайна доза дексаметазону становить 0,6 мг/кг [62]. Однак у чотирьох рандомізованих клінічних випробуваннях, що включали дози 0,15 мг/кг, було виявлено, що нижчі дози 
(0,15 мг/кг) однаково ефективні, хоча розміри вибірки були невеликими, і жодне з досліджень не продемонструвало доцільності використання цих доз [63-67]. 3 іншого боку, метааналіз контрольованих досліджень вказує, що вищі дози кортикостероїдів дають клінічно значущу відповідь у більшої кількості пацієнтів [56]. Отже, в очікуванні подальших клінічних випробувань неможливо визначити певні рекомендації щодо діапазону дозування, а використання як стандартної (0,6 мг/кг), так і меншої дози (0,15 мг/кг) є обгрунтованим.

Не було опубліковано жодних контрольованих досліджень, які б порівнювали переваги багаторазового введення кортикостероїдів перед одноразовим використанням. Проте, враховуючи короткочасну симптоматику крупу у більшості хворих, одноразового застосування кортикостероїдів, ймовірно, достатньо для більшості пацієнтів. Діти, які поступили в лікарню та мають тривалі симптоми, можуть отримати користь від повторних доз, проте необхідне подальше вивчення даного питання.

Коментар робочої групи. Чинним наказом МОЗ України № 437 від 31.08 .2004 «Про затвердження клінічних Протоколів надання медичної допомоги при невідкладних станах y дітей на шпитальному $i$ до шпитальному етапах» рекомендується застосування глюкокортикоїдів у розрахунку $10 \mathrm{мг/ \kappa г} \mathrm{на} \mathrm{добу} \mathrm{за} \mathrm{преднізолоном.} \mathrm{Дозу} \mathrm{рекомендують}$ розподіляти на 4-6 прийомів без дотримання біологічного ритму. Слід зазначити, що вказані рекомендації не мають відповідного рівня доказовості та суперечать визнаним у світі міжнародним рекомендаціям.

Показано, що інгаляційний будесонід є ефективним і еквівалентним пероральному дексаметазону [59,63]. Однак будесонід не є більш ефективним, ніж дексаметазон, зазвичай він більш травматичний для введення і значно дорожчий, тому його не слід регулярно використовувати. Винятком є пацієнти з важкою або загрозливою дихальною недостатністю, у яких одночасне застосування будесоніду та епінефрину є доцільним та може бути більш ефективним, ніж застосування лише епінефрину. Крім того, для тих дітей, у яких пероральні препарати викликають блювання, інгаляційне введення стероїдів може бути прийнятною альтернативою.

«Consensus guidelines for management of Croup» (Nothern California Pediatric Hospatal Medicine Consortium, 2016)

Слід призначати дексаметазон УСІМ пацієнтам з діагнозом «КРУП» незалежно від ступеня важкості.

НЕ Рекомендується призначати преднізон/преднізолон.

Коментар робочої групи. У зв'язку з відсутністю зареєстрованої форми дексаметазону у вигляді сиропу, рутинною практикою в Україні є застосування преднізону у вигляді супозиторїв ректальних для пацієнтів із крупом легкого ступеня.

«Diagnosis and management of croup» (Clinical Practice Guideline, Toward optimized practice, 2008)

Показання до госпіталізаціі

$\checkmark$ Значна дихальна недостатність, що триває 4 і більше годин після лікування кортикостероїдами:

- втягнення грудної клітки;

- стридор, що легко вислуховується у спокої.

$\checkmark$ Слід розглянути питання про госпіталізацію, якщо є:

- неможливість своєчасного доступу до медичної допомоги, ризик відсутності спостереження та виконання призначень, наприклад, велика відстань до медичного закладу, брак транспорту;

- значне занепокоєння батьків;

• декілька візитів до відділень невідкладної допомоги протягом останніх 24 годин. 
Стаціонарне лікування

$\checkmark$ Частий моніторинг стану дихальних шляхів, включно з підтримкою вітальних функцій та послідовними клінічними оглядами, зосередженими на оцінці ступеня дихальної недостатності

$\checkmark$ Внутрішньовенне введення рідини зазвичай використовується тільки у дітей із важкою дихальною недостатністю

$\checkmark$ Призначення відповідних ліків (див. Дод. 2)

$\checkmark$ НЕ застосовувати кисневі палатки [8,9]

$\checkmark$ Будьте готові до ускладнень

- Інтубація може знадобитися у невеликій кількості випадків (<1\% госпіталізованих пацієнтів) [15,18]

- Бактеріальний трахеїт може спричинити різке погіршання стану пацієнтів, яких спочатку діагностували як пацієнтів з крупом $[17,18]$

- Зупинка серцево-легеневої діяльності може виникати у пацієнтів, які не отримували адекватного спостереження і лікування

- Пневмонія є рідкісним ускладненням крупу [19]

Критерії виписки з відділення невідкладної допомоги

$\checkmark$ Наявність легких симптомів під час первинного огляду або після періоду спостереження $[20,21]$

$\checkmark$ Якщо симптоми не повторюються протягом 2-4 годин спостереження після лікування епінефрином [11,12,22-25]

$\checkmark$ Батьки можуть повернути дитину до лікарні, якщо ознаки дихальної недостатності повторяться вдома

$\checkmark$ Батькам було пояснено, колі слід звернутися по допомогу, та надано додаткову інформацію про круп

Спостереження

$\checkmark$ НЕ потрібне для більшості дітей з крупом [3]

$\checkmark$ Дітей із тривалим стридором (>одного тижня) слід спостерігати за участі лікаря первинної або невідкладної медичної допомоги

«Consensus guidelines for management of Croup» (Nothern California Pediatric Hospatal Medicine Consortium, 2016)

Слід розглянути необхідність повторної консультації через 24-48 годин від первинної консультації/виписки зі стаціонару по телефону або очно залежно від комплаєнсу з пацієнтом та територіальної доступності медичного закладу.

«Diagnosis and management of croup» (Clinical Practice Guideline, Toward optimized practice, 2008)

\section{Висновки}

Круп є однією з найпоширеніших причин обструкції верхніх дихальних шляхів у дітей віком від 6 місяців до 3 років, також може виникати у дітей віком до 3 місяців, дітей старшого віку та підлітків [1]. Круп зустрічається переважно наприкінці осені, але може виникнути в будь-який сезон, включаючи літо. Він, як правило, викликається вірусом парагрипу, однак причиною можуть бути й інші віруси $[27,28]$.

Круп характеризується раптовим нападом гавкаючого кашлю, захриплістю голосу, інспіраторною задишкою та респіраторним дистресом, викликаними запаленням верхніх дихальних шляхів внаслідок вірусної інфекції. Зазвичай немає необхідності в жодних лабораторних та інструментальних дослідженнях, адже діагноз можна виставити на підставі клінічної картини у поєднанні з анамнезом та даними фізикального огляду. Диференціальну діагностику слід проводити з бактеріальним трахеїтом, епіглотитом, аспірацією стороннього тіла, гострою алергічною реакцією, ретрофарингеальним та паратонзилярним абсцесом. Тактика ведення пацієнта залежить від ступеня важкості крупу, проте дексаметазон рекомендується призначати всім дітям, у яких діагностовано круп (у тому числі тим, які мають кашель без жодних 
ознак дихальної недостатності). Перевагу, за можливості, слід надавати пероральному застосуванню дексаметазону. Епінефрин інгаляційно рекомендується призначати при важких дихальних розладах для тимчасового полегшення симптомів обструкції дихальних шляхів. Інгаляційний будесонід не є препаратом вибору при лікуванні крупу, проте може бути застосований для пацієнтів із постійним блюванням та у випадку важкої дихальної недостатності у комбінації з епінефрином. Немає жодної потреби у призначенні антибіотиків, НПЗП, антигістамінних засобів та бета-2-агоністів. Седація пацієнта протипоказана. Важливо створити комфортні умови дитині, уникати болісних процедур, медичні працівники повинні бути особливо уважними, щоб не лякати їі під час догляду та лікування.

Основною причиною занепокоєння батьків та лікарів є питання респіраторної підтримки [30], проте переважна більшість дітей може безпечно лікуватись вдома, адже відсоток тих, хто вимагає штучної підтримки прохідності дихальних шляхів, дуже малий [26].

Алгоритм амбулаторного ведення крупу у дітей відповідно до рівня важкості

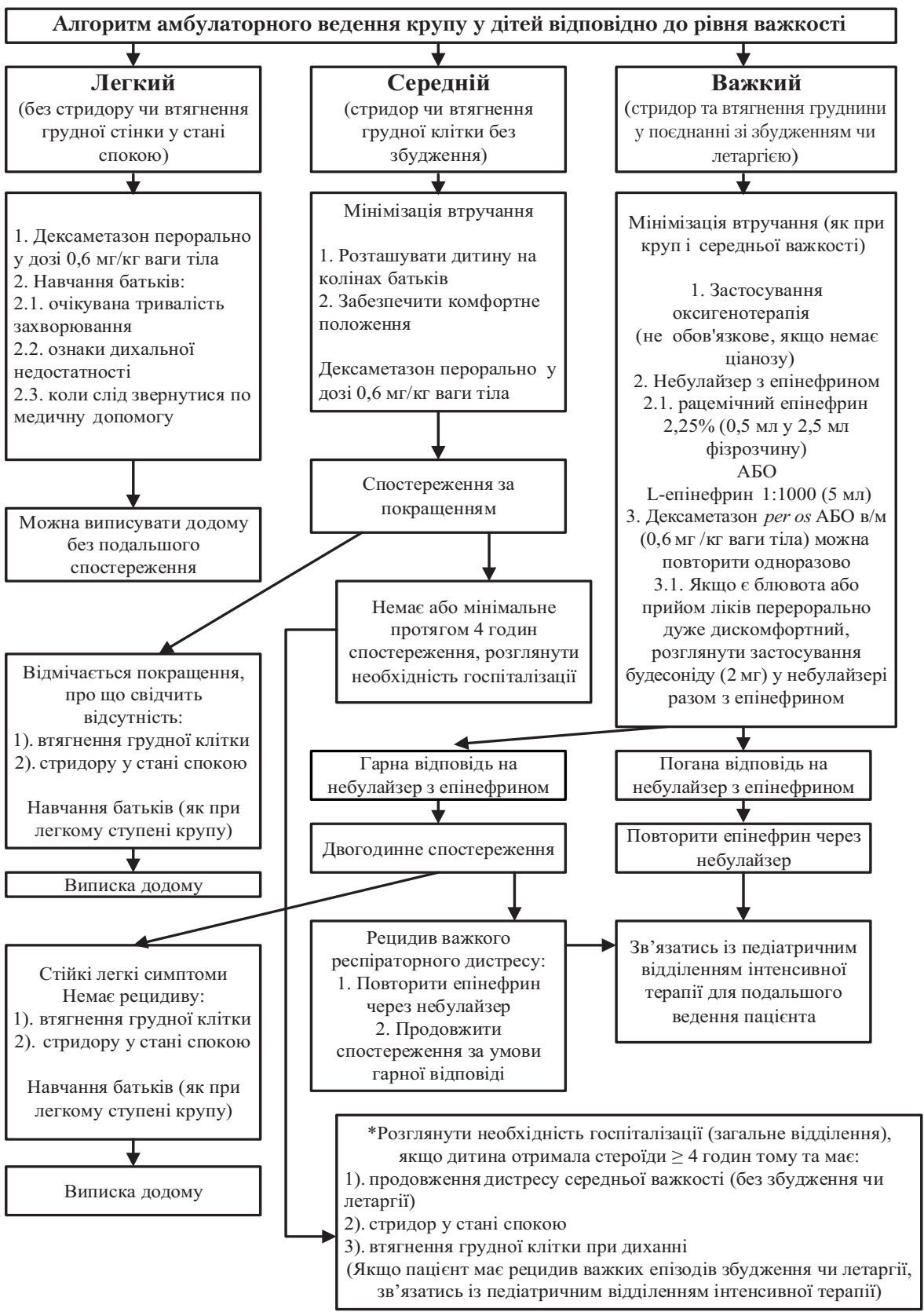




\section{Фармакологія}

Додаток 2

\begin{tabular}{|c|c|c|}
\hline Категорія ліків & Доза та тривалість & Коментар \\
\hline $\begin{array}{l}\text { Адренергічні } \\
\text { агоністи } \\
\text { - Епінефрин }\end{array}$ & $\begin{array}{l}\text { - Рацемічний епінефррин 0,5 мл } \\
2,25 \% \text { розчину, розведеного у } \\
2,5 \text { мл NaCl чи води } \\
\text { для ін'єкцій через небулайзер } \\
\text { - L-епінефррин 1:1000 розчин } \\
5 \text { мл через небулайзер } \\
\text { - Може бути повторено } \\
\text { «доза за дозою» у дітей } \\
\text { з важкою дихальною } \\
\text { недостатністю }\end{array}$ & $\begin{array}{l}\text { - Рацемічний епінефрин i L-епінефрин еквівалентні з точки зору ефек- } \\
\text { ту та безпеки } \\
\text { - Рацемічний епінефрин більше не доступний у Північній Америці } \\
\text { - Тривалість дії епінефрину не перевищує двох годин. Пацієнт повинен } \\
\text { виписуватись із медичного закладу щонайменше через дві години } \\
\text { після отримання дози епінефрину. } \\
\text { - У дитини з постійною блювотою небулайзерна форма будесоніду } \\
\text { може комбінуватись та одночасно вводитись з епінефррином }\end{array}$ \\
\hline $\begin{array}{l}\text { Кортикостероїди } \\
\text { - Дексаметазон }\end{array}$ & $\begin{array}{l}\text { - 0,6 мг/кг перорально/ } \\
\text { внутрішньом'язово } \\
\text { одноразово } \\
\text { - Можна повторити дозу } \\
\text { протягом 6-24 годин }\end{array}$ & $\begin{array}{l}\text { - Пероральний дексаметазон добре всмоктується і досягає пікових } \\
\text { концентрацій у сироватці так само швидко, як і при внутрішньом'язе- } \\
\text { вому введенні (без болю!) } \\
\text { - Кілька контрольованих досліджень дозволяють зробити висновок } \\
\text { про еквівалентність результатів перорального та внутрішньом'язового } \\
\text { введення дексаметазону } \\
\text { - Досвід показує, що клінічне поліпшення розпочинається через 2-3 } \\
\text { години після лікування } \\
\text { - Можна розглядати введення нижчих (0,15 мг/кг перорально/внутріш- } \\
\text { ньом'язово) доз } \\
\text { - Не існує жодних доказів щодо додаткової користі від застосування } \\
\text { декількох доз } \\
\text { - Скорочення: } \\
\text { о Частоти та тривалості інтубації } \\
\text { о Частоти і тривалості госпіталізації } \\
\text { о Рівня повторних звернень по медичну допомогу } \\
\text { о Тривалості симптомів у дітей з легкими, середніми та важкими фоор- } \\
\text { мами крупу }\end{array}$ \\
\hline - Будесонід & - $2 \mathrm{M \Gamma}$ & $\begin{array}{l}\text { - У переважній більшості випадків будесонід не має ніяких переваг } \\
\text { перед дексаметазоном і є значно дорожчим } \\
\text { - Може бути корисним у пацієнтів } \\
\text { з блюванням, важкою дихальною недостатністю; будесонід та епіне- } \\
\text { фрин можна вводити одночасно }\end{array}$ \\
\hline
\end{tabular}

\section{Перелік використаної літератури}

\section{A. “DIAGNOSIS AND MANAGEMENT OF CROUP» (Clinical Practice Guideline, Toward optimized practice, 2008)}

1. Denny, F, et al. Croup: an 11-year study in a pediatric practice. J Pediatr. 1983; 71 (No. 6): 871-6.

2. Tong, MC, et al. Adult croup. Chest. 1996. 109(6):1659-62.

3. Johnson, DW, Williamson J. Croup: Duration of symptoms and impact on family functioning. Pediatr Research. 2001;49:83A.

4. Heikkinen $\mathrm{T}$, Thint $\mathrm{M}$, Chonmaitree $\mathrm{T}$. Prevalence of various respiratory viruses in the middle ear during acute otitis media. $\mathrm{N}$ Eng J Med. 1999;340(4):260-4.

5. Bjornson CL, Johnson DW. Croup in children. CMAJ. 2013 Oct 15;185(15):1317-23.doi: 10.1503/cmaj.121645.

6. Rapkin, $\mathrm{RH}$. The diagnosis of epiglottitis: simplicity and reliability of radiographs of the neck in the differential diagnosis of the croup syndrome. J Pediatr. 1972;80(1):96-8.

7. Newth CJ, Levison H, Bryan AC. The respiratory status of children with croup. J Pediatr, 1972;81(6):1068-73.

8. Moore M, Little P. Humidified air inhalation for treating croup: a systematic review and meta-analysis. Fam Pract. 2007;24:295-301.

9. Scolnik D, Coates AL, Stephens D, Da Silva Z, Lavine E, Schuh S. Controlled delivery of high vs low humidity vs mist therapy for croup in emergency departments: a randomized controlled trial. JAMA. 2006 Mar 15;295(11):1274-80.

10. Waisman Y, et al. Prospective randomized double-blind study comparing L-epinephrine and racemic epinephrine aerosols in the treatment of laryngotracheitis (croup). Pediatrics. 1992;89:302-6.

11. Corneli HM, Bolte RG. Outpatient use of racemic epinephrine in croup. Am Fam Phys. 1992;46(3):683-4. 
12. Ledwith CA, Shea LM, Mauro RD. Safety and efficacy of nebulized racemic epinephrine in conjunction with oral dexamethasone and mist in the outpatient treatment of croup. Ann Emerg Med. 1995;25: 331-7.

13. Johnson D, et al. Outpatient treatment of croup with nebulized dexamethasone. Arch Pediatr Adolesc Med. 1996;150 (April):349-55.

14. Patel $\mathrm{H}$, Macarthur $\mathrm{C}$, Johnson $\mathrm{D}$. Recent corticosteroid use and the risk of complicated varicella in otherwise immunocompetent children. Arch Pediatr Adolesc Med. 1996;150:409-14.

15. Sofer S, Dagan R, Tal R. The need for intubation serious upper respiratory infection in pediatric patients (a retrospective study). Infection, 1991. 19: 131-4.

16. Tan AKW, Manoukian J. Hospitalized croup (bacterial and viral); the role of rigid endoscopy. J Otolaryngol. 1992;21:48-53.

17. Donnelly B, McMillan J, Weiner L. Bacterialtracheitis: report of eight new cases and review. Rev Infect Dis. 1990;12:729-35.

18. Edwards KM, Dundon C, Altemeier WA. Bacterialtracheitis as a complication of viral croup. Pediatr Infect Dis J. 1983;2:390-1.

19. Super DM, et al. A prospective randomized double-blind study to evaluate the effect of dexamethasone in acute laryngotracheitis. J Pediatr. 1989;115:323-9.

20. Chin R, et al. Effectiveness of a croup clinical pathway in the management of children with croup presenting to an emergency department. J Paediatr Child Health. 2002;38:382-7.

21. Wagener JS, et al. Management of children hospitalized for laryngotracheobronchitis. Pediatr Pulmonol. 1986;2:159-62.

22. Westley C, Ross CEK, Brooks JG. Nebulized racemic epinephrine by IPPB for the treatment of croup. Am J Dis Child. 1978; 132(May):484-7.

23. Rizos JD, et al. The disposition of children with croup treated with racemic epinephrine and dexamethasone in the emergency department. J Emerg Med. 1998;16(4):535-9.

24. Kunkel NC, Baker.MD. Use of racemic epinephrine, dexamethasone, and mist in the outpatient management of croup. Pediatr Emerg Care. 1996;12(3):156-9.

25. Kelley PB, Simon JE. Racemic epinephrine use in croup and disposition. Am J Emerg Med. 1992;10(3):181-3.

26. Johnson DW, Williamson J. Health care utilization by children with croup in Alberta. Pediatr Res. 2003;53:110A.

27. Rihkanen H, Ronkko E, Nieminen T, Komsi KL, Raty R, Saxen H, Ziegler T, Roivainen M, Soderlund-Venermo M, Beng AL, Hovi T, Pitkaranta A. Respiratory viruses in laryngeal croup of young children. J Pediatr. 2008;152:661-5.

28. Miller EK, Gebretsadik T, Carroll KN, Dupont WD, Mohamed YA, Morin LL, Heil L, Minton PA, Woodward K, Liu Z, Hartert TV,Williams JV. Viral etiologies of infant bronchiolitis, croup and upper respiratory illness during 4 consecutive years. Pediatr Infect Dis J. 2013;32:950-5

29. Petrocheilou A, Tanou K, Kalampouka E, Malakasioti G, Giannios C, Kaditis AG. Viral croup: diagnosis and a treatment algorithm. Pediatr Pulmonol. 2014 May;49(5):421-9.

30. D'Angelo AF, McGillivray D, Kramer M. Will my baby stop breathing? A study of parental concerns and family impact in mild croup. Pediatr Res. 2001;49:83A.

31. Rosychuk RJ, Klassen TP, Metes D, Voaklander DC, Senthilselvan A, Rowe BH. Croup presentations to emergency departments in Alberta, Canada: a large population-based study. Pediatr Pulmonol. 2010 Jan;45(1):83-91. doi: 10.1002/ppul.21162.

32. Esclamado RM, Richardson MA. Laryngotracheal foreign bodies in children. A comparison with bronchial foreign bodies. Am J Dis Child. 1987;141:259-62.

33. Cherry JD. Clinical practice: croup. N Engl J Med. 2008;358:384-91.

34. Davis GM. An examination of the physiological consequences of chest wall distortion in infants with croup. In: Medical science. Calgary, Canada: University of Calgary; 1985:90.

35. Davis GM, Cooper DM, Mitchell I. The measurement of thoraco-abdominal asynchrony in infants with severe laryngotracheobronchitis. Chest. 1993;103:1842-8.

36. Marx A, et al. Pediatric hospitalizations for croup (laryngotracheobronchitis): biennial increases associated with human parainfluenza virus 1 epidemics. J Infect Dis. 1997;176:1423-7.

37. Henry R. Moist air in the treatment of laryngotracheitis. Arch Dis Child. 1983;58:577.

38. Terregino CA, Nairn SJ, Chansky ME. The effect of heliox on croup: a pilot study. Acad Emerg Med. 1998;5:1130-3.

39. McGee DL, Wald DA, Hinchliffe S. Helium-oxygen therapy in the emergency department. J Emerg Med, 1997;15:291-6.

40. Beckmann KR, Brueggemann WM. Heliox treatment of severe croup. Am J Emerg Med, 2000;18:735-6.

41. Duncan PG. Efficacy of helium-oxygen mixtures in the management of severe viral and post-intubation croup. Can Anaesth Soc J. 1979;26(3):206-12.

42. Kemper KJ, et al. Helium-oxygen mixture in the treatment of postextubation stridor in pediatric trauma patients. Crit Care Med. 1991;19(3):356-9.

43. Moraa I, Sturman N, McGuire T, van Driel ML, Editorial group: Cochrane acute respiratory infections group published online: 2013 Dec 7: Assessed as up-to-date: 2013 Nov 12. doi: 10.1002/14651858.CD006822.pub4.

44. Adair JC, et al. Ten-year experience with IPPB in the treatment of acute laryngotracheobronchitis. Anesth Analg. 1971;50:649-55.

45. Fanconi S, et al. Transcutaneous carbon dioxide pressure for monitoring patients with severe croup. J Pediatr. 1990;117:701-5.

46. Taussig LM, et al. Treatment of laryngotracheobronchitis (croup). Am J Dis Child. 1975;129:790-3.

47. Corkey $\mathrm{C}$, et al. Radiographic tracheal diameter measurements in acute infectious croup: an objective scoring system. Crit Care Med. 1981;9(8):587-90.

48. Steele DW, et al. Pulsus paradoxus: an objective measure of severity in croup. Am J Respir Crit Care Med. 1997;156:331-4.

49. Fogel JM, et al. Racemic epinephrine in the treatment of croup: nebulization alone versus nebulization with intermittent positive pressure breathing. J Pediatr. 1982;101(6):1028-31.

50. Gardner HG, et al. The evaluation of racemic epinephrine in the treatment of infectious croup. Pediatrics. 1973;52(1):52-5. 
51. Johnson DW, et al. A comparison of nebulized budesonide, intramuscular dexamethasone, and placebo in moderately severe croup. N Eng J Med. 1998;339:498-503.

52. Butte MJ, et al. Pediatric myocardial infarction after racemic epinephrine administration. Pediatrics. 1999;104:e9.

53. Russell KF, Liang Y, O'Gorman K, Johnson DW, Klassen TP. Glucocorticoids for croup. Cochrane Database Syst Rev. 2011 Jan 19; (1):CD001955.

54. Bjornson CL, Klassen TP, Williamson J, Brant R, Mitton C, Plint A, Bulloch B, Evered L, Johnson DW. A randomized trial of a single dose of oral dexamethasone for mild croup. N Engl J Med. 2004;351:1306-13.

55. Tibballs J, Shann FA, Landau LI. Placebo-controlled trial of prednisolone in children intubated for croup. Lancet. 1992;340:740-8.

56. Kairys S, Olmstead EM, O'Connor GT. Steroid treatment of laryngotracheitis: a meta-analysis of the evidence from randomized trials. Pediatrics. 1989;83(No. 5):683-93.

57. Donaldson $\mathrm{D}$, et al. Intramuscular versus oral dexamethasone for the treatment of moderate-to-severe croup: a randomized, double-blind trial. Acad Emerg Med. 2003;10(1):16-21.

58. Rittichier KK, Ledwith CA. Outpatient treatment of moderate croup with dexamethasone: intra-muscular versus oral dosing. Pediatrics. 2000;106(6):1344-8.

59. Klassen TP, et al. Nebulized budesonide and oral dexamethasone for treatment of croup: a randomized controlled trial. JAMA. 1998;279:1629-32.

60. Duggan DE, et al. Bioavailability of oral dexamethasone. Clin Pharmacol Ther. 1975;18:205-9.

61. Dobrovoljac M, Geelhoed GC. How fast does oral dexamethasone work in mild to moderately severe croup? A randomized doubleblinded clinical trial. Emerg Med Australas. 2012;24:79-85.

62. Orenstein DM, Acute inflammatory upper airway obstruction. In: Nelson textbook of pediatrics, Behrman RE, Kleigman RM, Jenson HB, editors. Philadelphia: WB Saunders Company; 2000. 1274-9.

63. Geelhoed GC, W.B.G. Macdonald WBG. Oral dexamethasone in the treatment of croup: $0.15 \mathrm{mg} / \mathrm{kg}$ versus $0.3 \mathrm{mg} / \mathrm{kg}$ versus $0.6 \mathrm{mg} / \mathrm{kg}$. Pediatr Pulmono. 1995;20:362-8.

64. Geelhoed GC, Turner J, Macdonald WBG. Efficacy of a small single dose of oral dexamethasone for outpatient croup: a double blind placebo control-led clinical trial. BMJ. 1996;313:140-2.

65. Alshehri M, Almegamsi T, Hammdi A. Efficacy of a small dose of oral dexamethasone in croup. Biomed Res. 2005;16:65-72.

66. Fifoot AA, Ting JY. Comparison between single-dose oral prednisolone and oral dexamethasone in the treatment of croup: a randomized, double-blinded clinical trial. Emerg Med Australas. 2007;19:51-8.

67. Chub-Uppakarn S, Sangsupawanich P. A randomized comparison of dexamethasone $0.15 \mathrm{mg} / \mathrm{kg}$ versus $0.6 \mathrm{mg} / \mathrm{kg}$ for the treatment of moderate to severe croup. Int J Pediatr Otorhinolaryngol. 2007;71:473-7.

\section{B. "ACUTE MANAGEMENT OF CROUP IN THE EMERGENCY DEPARTMENT» (Canadian Paediatric Society, 2017)}

1. Bjornson CL, Johnson DW. Croup in children. CMAJ 2013;185(15):1317-23.

2. Bjornson CL, Klassen TP, Williamson J, et al.; PediatricEmergency Research Canada Network. A randomized trial of a single dose of oral dexamethasone for mild croup. N Engl J Med 2004; 351(13):1306-13.

3. Rosychuk RJ, Klassen TP, Metes D, Voaklander DC, Senthilselvan A, Rowe BH. Croup presentations to emergency departments in Alberta, Canada: A largepopulation-based study. Pediatr Pulmonol 2010;45(1):83-91.

4. McEniery J, Gillis J, Kilham H, Benjamin B. Review of intubation in severelaryngotracheobronchitis. Pediatrics 1991;87(6):847-53.

5. Hampers LC, Faries SG. Practice variation in the emergency management of croup. Pediatrics 2002;109(3):505-8.

6. Johnson DW, Craig W, Brant R, Mitton C, Svenson L, Klassen TP. A cluster randomized controlled trial comparing three methods of disseminating practice guidelines for children with croup [ISRCTN73394937]. Implement Sci 2006;(1):10.

7. Rihkanen H, Ronkko E, Nieminen T, et al. Respiratory viruses in laryngeal croup of young children. J Pediatr2008; 152(5):661-5.

8. Rosychuk RJ, Klassen TP, Voaklander DC, Senthilselvan A, Rowe BH. Seasonality patterns in croup presentations to emergency departments in Alberta, Canada: A time series analysis. Pediatr Emerg Care 2011;27(4):256-60.

9. Bjornson CL, Johnson DW. Croup in the paediatric emergency department. Paediatr Child Health 2007;12(6):473-7.

10. Fitzgerald DA. The assessment and management of croup. Paediatr Respir Rev 2006;7(1):73 81.

11. Chan A, Langley J, Leblanc J. Interobserver variability of croup scoring in clinical practice. Paediatr Child Health 2001;6(6):347-51.

12. Toward Optimized Practice. Diagnosis and Management of Croup. Clinical Practice Guideline, January 2008. www.topalbertadoctors.org/download/252/croup_guideline.pdf (Accessed September 27, 2016).

13. Moore M, Little P. Humidified air inhalation for treating croup. Cochrane Database Syst Rev 2006; (3):CD002870.

14. Russell KF, Liang Y, O'Gorman K, Johnson DW, Klassen TP. Glucocorticoids for croup. Cochrane Database Syst Rev 2011;(1): CD001955.

15. Kairys SW, Olmstead EM, O'Connor GT. Steroid treatment of laryngotracheitis: A meta analysis of the evidence from randomized trials. Pediatrics 1989;83(5): 683-93.

16. Ausejo M, Saenz A, Pham B, et al. The effectiveness of glucocorticoids in treating croup: Meta-analysis. BMJ 1999;319(7210):595-600.

17. Geelhoed GC. Budesonide offers no advantage when added to oral dexamethasone in the treatment of croup. Pediatr Emerg Care 2005;21(6):359-62.

18. Geelhoed GC, Macdonald WB. Oral dexamethasone in the treatment of croup: $0.15 \mathrm{mg} / \mathrm{kg}$ versus $0.3 \mathrm{mg} / \mathrm{kg}$ versus $0.6 \mathrm{mg} / \mathrm{kg}$. Pediatr Pulmonol 1995;20(6):362-8. 
19. Bjornson C, Russell KF, Vandermeer B, Durec T, Klassen TP, Johnson DW. Nebulized epinephrine for croup in children. Cochrane Database Syst Rev 2013;10:CD006619.

20. Prendergast M, Jones JS, Hartman D. Racemic epinephrine in the treatment of laryngotracheitis: Canwe identify children for outpatient therapy? Am J Emerg Med 1994;12(6):613-6.

21. Kelley PB, Simon JE. Racemic epinephrine use in croup and disposition. Am J Emerg Med 1992;10(3):181-3.

22. Corneli HM, Bolte RG. Outpatient use of racemic epinephrine in croup. Am Fam Physician 1992;46(3):683-4.

23. Zhang L, Sanguebsche LS. The safety of nebulization with 3 to $5 \mathrm{ml}$ of adrenaline (1:1000) in children: An evidence based review. J Pediatr (Rio J) 2005;81(3): 193-7.

24. Moraa I, Sturman N, McGuire T, van Driel ML. Heliox for croup in children. Cochrane Database Syst Rev 2013; (12):CD006822.

C. "CONSENSUS GUIDELINES FOR MANAGEMENT OF CROUP» (Nothern California Pediatric Hospatal Medicine Consortium, 2016)

1. Beigelman A, Chipps BE, Bacharier LB. Update on the utility of corticosteroids in acute pediatric respiratory disorders. Allergy Asthma Proc, 2015;36:332-338.

2. Bjornson C, et al. 2011. Nebulized epinephrine for croup in children. Cochrane Database of Systematic Reviews, 2, 006619.

3. Cetinkaya F, Tufekci BS, Kutluk G. A comparison of nebulized budesonide, and intramuscular, and oral dexamethasone for treatment of croup. . Int J Pediatr Otorhinolaryngol, 2004;68(4): 453-456.

4. Johnson DW, Jacobson S, Edney PC, et al. A comparison of nebulized budesonide, intramuscular dexamethasone, and placebo for moderately severe croup. N Engl J Med, 1998;339:498-503.

5. Mandal A, Kabra SK, Lodha R. Upper Airway Obstruction in Children. Indian J Pediatr, 2015;82(8):737-744.

6. Petrocheilou A, Tanou K, Kalampouka E, et al. Viral Croup: Diagnosis and a Treatment Algorithm. Pediatr Pulmonol, 2014;49:421-429.

7. Russel KF, et al. 2011. Glucocorticoids for croup. Cochrane Database of Systematic Reviews, 1, 001955.

8. Taketomo CK, Hodding JH, Kraus DM. Pediatric \& Neonatal Dosage Handbook: A Universal Resource for Clinicians Treating Pediatric and Neonatal Patients, 21st ed. Hudson, OH: Lexi-Comp, 2014.

9. Zoorob, R, Sidani M, Murray J. Croup: An Overview. Am Fam Physician, 2011;83(9):1067-1073.

10. Published U.S. Children's Hospital Croup Guidelines / Pathways: o Children ' s Hospital of Philadelphia Pathways (links):

11. Emergency Department Pathway: http://www.chop.edu/clinical-pathway/croup-emergent-evaluation-and-treatment-clinicalpathway\# o Inpatient Pathway: http://www.chop.edu/clinical-pathway/croup-clinical-pathway

12. Seattle Children 's Hospital Pathway (PDF):

13. http://www.seattlechildrens.org/healthcare-professionals/gateway/pathways/

14. University of Cincinnati Best Evidence Statement (PDF): http://www.cincinnatichildrens.org/service/j/anderson-center/evidence-based-care/recommendations/topic/

15. Colorado Children s Hospital Guideline (PDF): http://www.childrenscolorado.org/health-professionals/referral-tools/referralguidelines

\section{ВНИМАНИЕ!}

\section{Изменения в оформлении списка литературы}

Согласно Приказу МОН Украины № 40 от 12.01.2017 г. «Об утверждении требований к оформлению диссертаций» вносятся изменения в оформление списка литературы в журнале. Теперь оформление осуществляется в соответствии со стилем APA (American Psychological Association style), используемым в диссертационных работах.

\section{Примеры оформления литературных источников}

Журнальная публикащия

Автор АА, Автор ВB, Автор СС. (2005). Название статьи. Название журнала. 10(2); 3: 49-53.

Книга

Автор АА, Автор ВВ, Автор СС. (2006). Название книги. Город: Издательство: 256.

Глава в книге

Автор АА, Автор ВВ, Автор СС. (2006). Название раздела (главы). В кн. Автор книги. Название книги. Под ред. Фамилия СС. Город: Издательство: 256.

Интернет-ресурс

Автор АА, Автор ВВ, Автор СС. (2006). Название статьи. Название журнала/книги (если есть). URL-адрес публикации.

Оформление литеры по новым требованиям повысит возможности поисковых ресурсов в интернете, и, как следствие, цитируемость авторов. 


\section{5-16 ЛИСТОПАДА 2019}

Україна, Київ - Chamber Plaza • вул. Велика Житомирська, 33

\section{NOVEMBER 15-16, 2019}

Ukraine, Kyiv • Chamber Plaza • 33, Velyka Zhytomyrska Str.

2nd International Congress

RATIONAL USE OF ANTIBIOTICS

\section{ANTIBIOTIC}

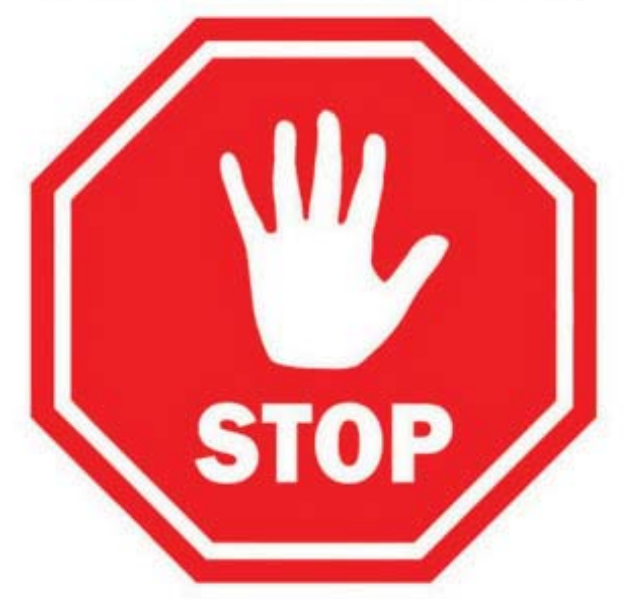

\section{RESISTANCE}

II Міжнародний Конгрес

РАЦІОНАЛЬНЕ ВИКОРИСТАННЯ АНТИБІОТИКІВ

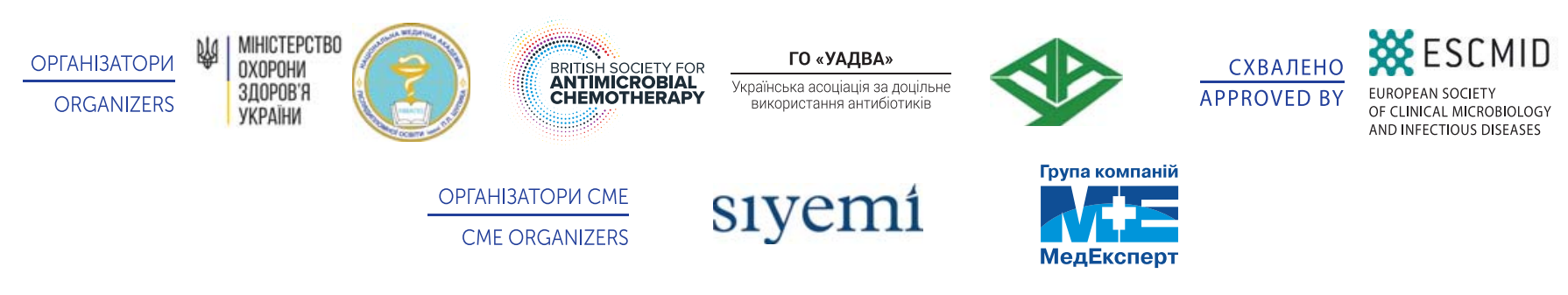

\section{antibiotic-congress.com}




\section{Правилаподачии иформлениястатей}

Авторская статья направляется в редакцию по электронной почте в формате MS Word. Статья сопровождается официальным направлением от учреждения, в котором была выполнена работа, с визой руководства (научного руководителя), заверенной круглой печатью учреждения, экспертным заключением о возможности публикации в открытой печати, заключением этического комитета учреждения или национальной комиссией по биоэтике. На последней странице статьи должны быть собственноручные подписи всех авторов и информация о процентном вкладе в работу каждого из авторов. Принимаются оригиналы сопроводительных документов с приложением печатного экземпляра рукописи, подписанного автором(ами), официального направления, присланные по почте, или сканированные копии вышеприведенных документов и первой (титульной) страницы статьи с подписью всех авторов статьи в формате Adobe Acrobat (*.pdf), присланные на электронный адрес редакции.

Статьи принимаются на украинском, русском или английском языках

Структура материала: введение (состояние проблемы по данным литературы не более 5-7-летней давности); цель, задачи, материалы и методы; результаты исследований и их обсуждение (освещение статистически обработанных результатов исследования); выводы; перспективы дальнейших исследований в данном направлении; список литературы (два варианта), рефераты на русском, украинском и английском языках.

Реферат является независимым от статьи источником информации, кратким и последовательным изложением материала публикации по основным разделам и должен быть понятен без самой публикации. Его объем не должен превышать 200-250 слов. Обязательно указываются ключевые слова (от 3 до 8 слов) в порядке значимости, способствующие индексированию статьи в информационно-поисковых системах.

Реферат к оригинальной статье должен быть структурированным и повторять структуру статьи: цель исследования; материалы и методы; результаты; выводы; ключевые слова. Все разделы в реферате должны быть выделены в тексте жирным шрифтом.

Для остальных статей (обзор, лекции, клинический случай и др.) реферат должен включать краткое изложение основной концепции статьи и ключевые слова.

На первой странице указываются: индекс УДК слева, инициалы и фамилии авторов, название статьи, название учреждения, где работают авторы, город, страна.

При проведении исследований с привлечением любых материалов человеческого происхождения в разделе «Материалы и методы» авторы должны указывать, что исследования проводились в соответствии со стандартами биоэтики, были одобрены этическим комитетом учреждения или национальной комиссией по биоэтике. То же самое относится и к исследованиям с участием лабораторных животных.

Например: «Исследование было выполнено в соответствии с принщипами Хельсинской Декларации. Протокол исследования был одобрен Локальным этическим комитетом (ЛЭК) для всех участвующих».

«При проведении экспериментов с лабораторными животными все биоэтические нормы и рекомендации были соблюдены».

Количество иллюстраций (рисунки, схемы, диаграммы) должно быть минимальным. Иллюстрации (диаграммы, графики, схемы) строятся в программах Word или Excel; фотографии должны быть сохранены в одном из следующих форматов: PDF, TIFF, PSD, EPS, AI, CDR, QXD, INDD, JPG (300 dpi).

Таблицы и рисунки помещают в текст статьи сразу после первого упоминания. В подписи к рисунку приводят его название, расшифровывают все условные обозначения (цифры, буквы, кривые и т.д.). Таблицы должны быть оформлены в соответствии с требованиями ГАК, компактными, пронумерованными, иметь название. Номера таблиц, их заголовки и цифровые данные, обработанные статистически, должны точно соответствовать приведенным в тексте.

Ссылки на литературные источники в тексте обозначаются цифрами в квадратных скобках, должны отвечать нумерации в списке литературы. Статьи со списком литературных источников в виде постраничных или концевых ссылок не принимаются.

Необходимо предоставлять два варианта списка литературы.

Первый вариант приводится сразу после текста статьи, источники располагаются по алфавиту (сначала работы, опубликованные на русском или украинском языках, далее - на других языках).

Второй вариант полностью повторяет первый, но источники на украинском и русском языках ПЕРЕВОДЯТСЯ! на английский язык. Он необходим для сайта, повішения индекса цитирования авторов и анализа статьи в международных наукометрических базах данных.

Оба варианта оформляются в соответствии со стилем APA (American Psychological Association style), используемым в диссертационных работах. Пример оформления для обоих вариантов:

Автор АA, Автор ВB, Автор СС. (2005). Название статьи. Название журнала. 10(2); 3: 49-53.

Автор АA, Автор ВB, Автор СС. (2006). Название книги. Город: Издательство: 256.

В тексте статьи допускаются общепринятые сокращения, а также авторские сокращения, которые обязательно расшифровываются в тексте при первом упоминании и остаются неизменными по всему тексту.

В конце статьи авторы должны заявить о наличии каких-либо конкурирующих финансовых интересов в отношении написания статьи. Указание конфликта интересов в статье является обязательным.

Пример: «Авторы заявляют об отсутствии конфликта интересов» или «Материал подготовлен при поддержке компании...»

Статья заканчивается сведениями обо всех авторах. Указываются фамилия, имя, отчество (полностью), ученая степень, ученое звание, должность в учреждении/учреждениях, рабочий адрес с почтовым индексом, рабочий телефон и адрес электронной почты; идентификатор ORCID (https://orcid.org/register). Сокращения не допускаются. Автор, ответственный за связь с редакцией, указывает свой мобильный/контактный номер телефона.

Ответственность за достоверность и оригинальность поданных материалов (фактов, цитат, фамилий, имен, результатов исследований и т.д.) несут авторы.

Редакция обеспечивает рецензирование статей, выполняет специальное и литературное редактирование, оставляет за собой право сокращать объем статей. Отказ авторам в публикации статьи может осуществляться без объяснения его причин и не считается негативным заключением относительно научной и практической значимости работы.

Статьи, оформленные без соблюдения правил, не рассматриваются и не возвращаются авторам. 

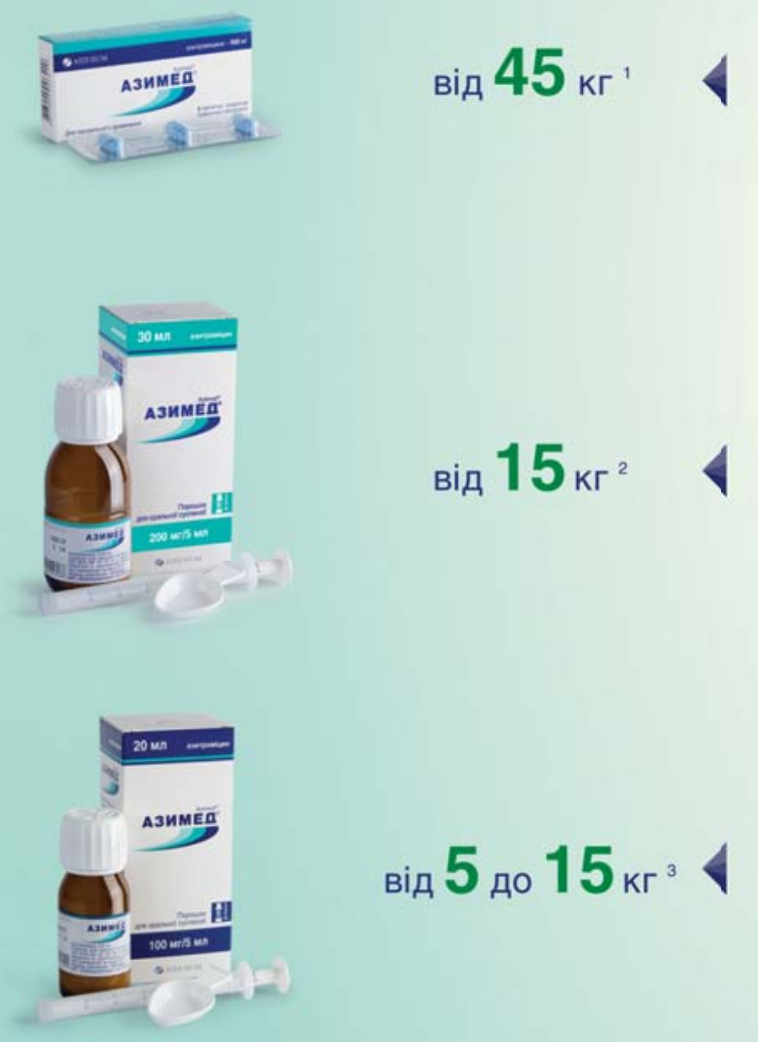

\section{АЗ ИМЕ $\square^{\odot}$}

\section{Інфекції долає просто, незалежно від зросту}

Азимед?, таблетки's.

Діюча речовина: azithromycin (азитроміцин): 1 таблетка містить азитроміцину дигідрату, у перерахуванні на азитроміцин, $500 \mathrm{mr}$.

Лiкарська форма. Таблетки, вкриті плівковою оболонкою.

Фармакотерапевтична грипз Антибактеріальні засоби для системного застосування. Макроліди, пінкозаміди та стрептограміни. Азитроміцин. Код АTX J01F A10.

Показання. Інфекцї, спричинені мікроорганізмами, чутливими до азитроміцину:

- інфекциї ЛОР-органів (бактеріальний фарингіт/тонзиліт, синусит, середній отит);

- інфекціі дихальних шляхів (бактеріальний бронхіт, негоспітальна пневмонія):

- інфекцй шкіри та м'яких тканик: мігруюча еритема (початкова старія хвороби Лайма), бешиха, імпегиго. вторинні піодерматози, лікування нетяжких форм Акне вульгаріс:

- інфекцй, що передаються статевим шляхом: неускладнений та ускладнений уретрит/цервіцит, спричинений Chlamydia trachomatis.

Протипоказання. Підвищена чутливість до азитроміцину, еритроміцину, до будь-якого макролідного або кетолідного антибіотика, до будь-якого іншого компонента препарату. Через теоретичну можливість ерготизму азитроміцин не спід призначати одночасно 3 похідними ріжків.

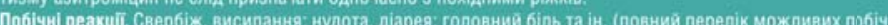
них реакцій наведено в інструкції для медичного застосування пікарського засобу)".

\section{1 Азимед 500 мr N.3 від $45 \mathrm{kr}$.}

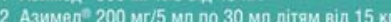

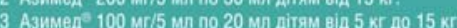

4 Оценка взаимозаменяемости Азимеда - 6иозквивалентность доказана! И. А. Зупанец, А. мед. Н., профессор; н. П. Безуглая, К. мед. Н., доцент; В. В. Либина, к. биол. н.; И. Н. Орлова, И. В. Кудрис, Ю. Г. Кувайское. Национальный фармацевтический университет, Харьков; пा =Государственныи зкспертный центр Министерства здравоохранения Украины: Корпорация -Артериумн, Киев. 시 (167) / 2013, “Ліки Українж.

5 Інформацію наведено в скороченому вигляді. Повна інформація викладена в Інструкцї для медичного застосування пікарського засобу Азимед", таблетки.

6 Інформацію наведено в скороченому вигляді. Повна інформація викладена в Інструкції для медичного застосування пікарського засобу Азимед, порошок для оральної суспензї.

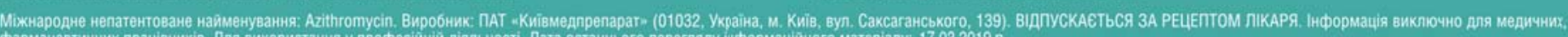
фармацевтичних праціаників. Для використання у професійній діяльності. Дата останнього перегляду іиформаційого матеріалу: 17.03.2019 p.

До складу Корпорації «Артеріум» входять ПАТ «Київмедпрепарат» та ПАТ «Галичфарм»

«Артеріум» Фармацевтична Корпорація www.arterium.ua 
